



\title{
THE OLD
}

\section{V.RGINIA GENTLEMAN} AND OTHER SKETCHES

\author{
BY \\ GEORGE W. BAGBY
}

EDITED WITH AN INTRODUCTION BY

THOMAS NELSON PAGE

NEW YORK

CHARLES SCRIBNER'S SONS

1910 
Copyright, 1884,1885 , BY MRS. GEORGE W. BAGBY

COPYRIGHT, I9IO, BY CHARLES SCRIBNER'S SONS

Published September, I9IO 


\section{PREFACE}

\section{A VIRGINIA REALIST}

Virginia, mother of States and statesmen, as she used to be called, has contributed many men of worth to the multitude that America can number. All her sons have loved her well, while many have reflected great honor on her. But of them all, none has known how to draw her portrait like that one who years ago, under the mild voice and quiet exterior of State Librarian and occasional contributor to the Periodical Press, hid the soul of a man of letters and an artist. Like many another man of letters who has enriched the world, George W. Bagby, before he "found himself," studied for a professional career-that vestibule to literature. He was first educated in part at Princeton, and later took the degree of M.D. at the University of Pennsylvania. After this he set up in Lynchburg, Virginia, as a practitioner of medicine. But the pen was much more grateful to his hand than the scalpel. He had the gift of seeing through the outer shell to the heart, and he soon began seeking in the 


\section{PREFACE}

columns of the nearest newspaper the expression of his dreams. His first article to attract attention was a paper on Christmas, published as an editorial in the Lynchburg Virginian. It brought him one great reward. It led to a life-long friendship with the accomplished gentleman, James MacDonald, who then edited the paper and became later the Secretary of State of Virginia. To this friendship Doctor Bagby years afterwards owed the appointment of Assistant Secretary of State and Librarian of the State Library, where, among the masters, his soul found society of its own rank. All his life, much of his work was thrown into the devouring maw of the daily press. His latest essays, as among his first, were papers which passed for letters or editorials, but were really literary essays which masked under these ephemeral names. Among these early contributions was the sketch entitled "The Sacred Furniture Warerooms," which is included in this volume. They gave him local celebrity, but nothing more.

Local men of letters were not highly esteemed in Virginia in the old days-at least, not professional men of letters who bore the traces of the soil on them. Her treasured genius ran in the direction of the forum or the tented field, where personal courage was always to be shown as the badge of honor. Thus, her men 
of ability mainly turned to these professions, and such literary gifts as Nature bestowed were mainly applied to the advocacy of governmental problems or to the polemics of political journalism.

William Wirt, who was a man of letters, concealed his passion under a pseudonym and only ventured to declare himself in a biography of one of Virginia's great orators after he had achieved fame as a noted lawyer.

"Why do you waste your time on a d-d thing like poetry?" demanded a neighbor of Philip Pendleton Cooke, the author of "Florence Vane." "A man of your position might be a useful man."

Even Poe, with a genius that is acknowledged the world over and that has never been surpassed in its kind, was never able to break through the defences with which established habit bulwarked itself among the burghers of Richmond and New York, and compel recognition of his extraordinary powers. His story is the saddest in the long line of neglected artists whose fate it has been to achieve fame too late to save them from perishing from want, of which destitution, want of food was the least part.

Next to Poe, the most original of all Virginia writers was he whose reputation in his lifetime mainly rested on humorous sketches of a mildly satirical and exceedvii 


\section{PREFACE}

ingly original type; but who was master of a pathos rarely excelled by any author and rarely equalled by any American author. Like Poe, his work was known among his contemporaries merely by a small coterie of friends. But these adored him.

Poe was the master of the absolutely imaginative sketch or tale-so purely imaginative that to discover any local color by which to give it locality it is necessary to analyze the work for unintentional traces of his surroundings. George IV. Bagby, on the other hand, was absolutely realistic-so purely realistic that no one can read, even at random, a page of his genre sketches and not recognize at once the truth of the picture, and -if he be a Virginian-point to its original. He was not a fictionist but a realist.

He scarcely ever penned a line that was not inspired by his love of Virginia and his appreciation of the life lived within her borders. Nearly all he wrote was of Virginia, pure and simple. Her love had sunk into his blood. But while he pictured Virginia, he reflected the human nature of the universe. He is set down in a recent biographical encyclopædia merely as "Physician and Humorist." He was much more than this. He was a physician by profession; a humorist by the way; but God made him a man of letters.

That portion of his work, indeed, which brought viii 


\section{PREFACE}

him most note in his lifetime among those who knew him were his humorous sketches and skits written in a sort of phonetic dialect which was the fashion of the time. It borders on broad farce, and, while it was always original and entertaining, its quaint humor, its most telling allusions, so often turned on local celebrities or histories as to lose their point with the outside reader. Thus, the "Mozis Addums's Letters"; “Meekinses' Twinses” and "What I Did with My Fifty Millions," however amusing to the general reader, could only be fully appreciated by those who hold the key to constant allusion to the Society of Richmond, which furnished the field of his harmless satire. "Meekinses' Twinses" brought him more immediate fame than any other of his writings; but who that did not know the author and his surroundings could appreciate the picture of "Meekins, the weerleeatenest man, I ever see!" Often in a line he drew a portrait so humorous, yet so exact, that acquaintances laughed over it for years. But they were portraits for his private collection and not for the public, and it is on his tenderer work that his literary fame must rest in the future.

Among all Virginia's writers few have had the love to feel and the gift to portray the Virginia life as Baghy had. He was the first to picture Virginia as she was. ix 


\section{PREFACE}

Other writers had magnified her through an idealism colored by reading of other life and other times. Caruthers, Simms, Kennedy, Cooke and other Southern writers all pictured the life of the South as reflected through the lenses of Scott, and his imitators, such as James. They dressed their gentlemen in wigs and ruffles and short clothes and their ladies in brocades and quilted stomachers and flashing jewels; housed them in palaces and of ten moved them on stilts with measured strut as automata strung on wires and worked, however skilfully, from behind the scenes. They spoke book-English and lived, if they lived at all, in slavish imitation of men of England, mirrored from the printed page of generations gone. The scenes were painted and so were the life and the speech. It was generally well done, often admirably done, but it was not real. And our people read English books, instead of American, to Poe's sad chagrin.

In this desert of unreality came a new writer, a contributor to newspapers and magazines, who, discarding the stilts and the struts and the painted palaces, pictured the old Virginia homesteads set back, simple and peaceful and plain, under their immemorial oaks and locusts, with the life lived there with its sweetness and simplicity and tender charm. Like Poe he was not generally valued-he was not an historian, nor 


\section{PREFACE}

even a novelist-only a writer of sketches. He had no fixed occupation and probably no fixed income. At least, his income must have been meagre. Had he paid attention to business, he might possibly, though not probably, have been a "Useful Man." As it was, he was rather given to wandering about the country, writing humorous sketches of life for the press"Wasting his time on a damned thing like poetry," for he wrote poetry though not generally verse.

Much of his work was lost. Other parts of it drifted into the wide main of anonymous writing, or was boldly claimed by others as their property-as for example, his description of "How Rubenstein Played," which is famous enough to be in all readers though unattributed to its author. But for all this he has his reward, for he has preserved the life of the people be loved and given it the charm that was its chief gracesimplicity.

When the old life shall have completely passed away as all life of a particular kind must pass, the curious reader may find in George W. Bagby's pages, pictured with a sympathy, a fidelity and an art which may he found nowhere else, the old Virginia life precisely as it was lived before the war, in the tidewater and southside sections of Virginia. If it was idealized-as, when was anything written of with enthusiasm not ideal$\mathrm{xi}$ 


\section{PREFACE}

ized? - the character and the portraiture alike were faithfully drawn, even if touched with a light of imagination; and the true secret of the art that portrayed them was the artist's love of the subject. He first of all discovered that in the simple plantation homes was a life more beautiful and charming than any that the gorgeous palaces could reveal, and that its best presentation was that which had the divine beauty of truth.

It is always difficult to gauge the measure of influences, but one writer has always felt that to George W. Bagby's pioneer work among the memories of the old Virginia life in its simplicity he owes an unending debt of gratitude. He opened his eyes to the beauty that lay at hand and whispered into his ear the charm that sang to his soul of the South.

I cannot forbear, in closing this preface, to quote his own words from the close of his essay on "The Old Virginia Gentleman," to my mind the most charming picture of American life ever drawn.

"I ask no man's pardon for what must seem to a stranger a most exaggerated estimate of my State and its people. In simple truth and beyond question there was in our Virginia country life a beauty, a simplicity, a purity, an uprightness, a cordial and lavish hospitality, warmth and grace which shine in the lens of memory with a charm that passes all language at my 


\section{PREFACE}

command. It is gone with the social structure that gave it birth, and were I great, I would embalm it in the amber of such prose and verse as has not been written since John Milton laid down his pen. Only greatness can fitly do it."

As the years pass by, the life he pictured so tenderly has faded more and more into the misty vague of the past; but it cannot be wholly lost. Glimpses of it have been preserved by a master's pencil; and it is in the hope of giving others the privilege which I have enjoyed so much that I have undertaken to edit this volume of the writings of George IV. Bagby.

Thomas Nelson Page. 



\section{CONTENTS}

PREFACE, "A VIRGINIA REALIST," BY THOMAS NELSON PAGE. . . • . • • . . . $\mathrm{v}$

SKETCH OF THE LIFE OF GEORGE WILLIAM BAGBY, BY EDWARD S. GREGORY . . . XVÏ̈

I. THE OLD VIRGINIA GENTLEMAN . . . . 1

II. BACON AND GREENS . . . . . . . . 45

III. MY UNCLE FLATBACK'S PLANTATION • • 69

IV. MY WIFE AND MY THEORY ABOUT WIVES • 107

v. FISHING IN THE APPOMATTOX . . . . . 121

VI. AN UNRENOWNED WARRIOR . . . . . . 135

VII. JOHN M. DANIEL'S LATCH-KEY • • • . . 166

VIII. THE VIRGINIA EDITOR . . . . . . . . 217

IX. CANAL REMINISCENCES . . . . . . . . 230

X. THE SACRED FURNITURE WAREROOM . . . 250

XI. MY VILE BEARD . . . . . . . . . . 257

XII. A PIECE ABOCT DOCTORS . . . . . . . 280

XIII. THE PAWNEE WAR . . . • . • . . . 290

XIV. HOW RUBENSTEIN PLAYED . . . • . . 301

XV. FILL JOANSES • • . • • • . . . . 308

XVI. AFTER APPOMATTOX . . . . . . . . . 311 



\section{GEORGE WILLIAM BAGBY}

The call of death has often proved an evangel to the man of letters in more than one way.

The subject of this sketch, though widely known throughout the Republic, and for years a dear guest in many homes of Virginia, though he loved and sought socicty, shared the same fate of misconception, or of inadequate conception, till death drew the veil and revealed the true proportions of his mental and moral manhood.

The main facts that punctuate the life and literary labors of George William Bagby may be briefly recited. The career of the man and the litterateur was largely professional, and may be left to find popular interpretation from the list and order of his works. The present volume introduces these but imperfectly and in part to the reading world. But if it fulfil its mission, and if the present generation prove able to appreciate and admire the mingled idyl and epic in which Dr. Bagby has embalmed the heroic and poetic Virginia of the past, some image may be formed, some memory quickened of one to whom many sins, if such there were, should be remitted-“ "for he loved much."

Dr. Bagby was born in the very heart of Virginia, in the county of Buckingham, on August 13, 1828. 
The section in which he first saw the light was characteristic of the man. It lies at the roots of the Blue Ridge; its social traits and genealogies are of the East, and its location, though south of the James, is near the natural continuation of the great valley. In one respect, especially, Buckingham was rich: in the facilities it afforded for the study of the peculiarities of negro dialect, fetich, and other and all racial idiosyncrasies. Never was there an apter pupil than the boy Bagby, since George Borrow made himself master of the Romany Lil.

As Bœotia was the right home of Pindar and Tyrtæus, so was this central county, with its wealth of black diamonds of every hue and form of originality and individuality, the right school for one who was destined to prove no less than the very Dickens and Shakespeare of the Virginia negro.

Dr. Bagby's father was a merchant of Lynchburg; his mother's maiden name was Evans-a patronymic that reappears in the letters of Mozis Addums. Dr. Bagby was educated at Princeton, N. J., and at Newark, Del., under the tuition of the late Dr. John S. Hart, one of the best of men and of teachers, who gave him an honored place in the Professor's "Manual of American Literature" (pp. 452-453). At the end of his sophomore year in Delaware College, young Bagby (now eighteen years old) began the study of medicine, and in due time took his regular degree of M.D. at the University of Pennsylvania, at Philadelphia. He then removed to Lynchburg, where his father lived, to practice, and he hung out his sign in front of a tenexviii 
ment that then stood on the site of the now stately Opera House of that city. But it may be doubted if really he ever attended half a dozen cases. By a law, however, as sure as that which rules the courses of gravitation, Bagby soon found, without seeking, the career for which every endowment of nature had copiously prepared and deliberately dedicated him. The Virginian of Lynchburg, founded in 1S0S, was then edited by James McDonald, Esq., since Secretary of the Commonwealth and Adjutant-General of Virginia, to whom, ten years after, Dr. Bagby wrote the tribute in "Blue Eyes," that he "was essentially a gentleman." To him, as to a kindred, even brother spirit, in culture and humanity, the young and eccentric stranger was naturally magnetized. Those were the good old days when people had plenty of elbow-room. When the editor was absent, his friend took his place; and under this gateway of locum tenens Dr. Bagby made his way upon the stage which he afterward so widely and so luminously filled. It was a happy omen that, on the appearance of his very first contribution, an editorial article on "Christmas," the town was taken by storm, and saw, as was said of Macaulay's "Milton," that a new star had risen above the horizon. But "the Dean could write beautifully about a broomstick." Sketch after sketch rapidly followed, some of which are included in this volume, and all of which are as well worthy to live as the earlier essays of Thackeray or Lamb; appearing in the poverty of literary apparatus in Virginia, for the most part as editorial articles in the Virginian. Among such was the essay entitled xix 
"The Sacred Furniture Warerooms," which neither Addison nor Irving would have disowned. Dr. Bagby has said to the writer that his literary fertility at that time was prodigious. He must have read ravenously also. Meanwhile, too, he was a man about town, and was known for a genius, and for one who would make, or had indeed already made, a shining mark.

Labor and fame came crowding upon him suddenly, as the fruit of this local distinction, and from the inspiration of this local success. Early in the fifties, the Lynchburg Express, a paper founded, and for some years conducted, by the late Hudson Garland, came into the possession of Dr. Bagby and his life-long friend, the late Capt. George Woodville Lathamanother rare and lit spirit, too soon involved in the damps of disease and the arrest of death. But the business management was neglected or ill-managed; and the Express -fortunately for Bagby-became numbered among Lynchburg epitaphs and eclipses.

During this time, Dr. Bagby wrote several articles that were published in Harper's Magazine. One of these was entitled "My Wife, and My Theory about Wives"-a specimen of sentimental extravaganza worthy of the hand which traced the shadowy and sacred image of the lost love of Sir Roger de Coverley. Another was entitled "The Virginia Editor," and was a burlesque character sketch of the swaggering, duelling, and drinking soi-disant "Colonel," who then only too often represented the power of the press in the sunny South.

It was professedly a caricature; and it had been $\mathrm{XX}$ 
shown, before its appearance, as a good joke, to numerous journalistic friends. Yet, when it was published, one of these was induced by other persons to regard it as an assault upon himself. He sent thereupon a challenge, which was promptly accepted;* seconds were named; Captain Latham for Bagby, and Roger A. Pryor for the party of the second part. Bladensburg was reached; the preliminaries were adjusted, and the principals took position. At this critical moment, a hack arrived containing the Hon. Thomas S. Bocock, then a Member of Congress, and a friend of all parties, through whose efforts the quarrel was composed, and everybody sent about his pacific business.

The collapse of the Express gave to each of its two editors more congenial employment, and an ampler field. Through the influence of Mr. Wm. M. Semple, lately before the associate editor of the Lynchburg Virginian, and at that time correspondent at Washington of the New Orleans Crescent, Dr. Bagby was promoted to the latter position; and, through family influence, Woodville Latham was employed as clerk of the Naval Committee of the House of Representatives.

It was the destiny of one to be a dreamer, a poet; and not much that he dreamed took a living form; but Bagby must have been a dauntless and indefatigable laborer, and the mere list of the publications for which he wrote affords proof of his heroic industry

* "George had all sorts of good pluck, and plenty of it; he was not afraid of any man's face on earth."-Dr. H. G. L. 
and of the fatal fertility of his genius. Besides the Crescent (in those days, remember, his letters were quasi editorial and had even a greater weight than that of mere local comment), he corresponded regularly for the Charleston Mercury and the Richmond Dispatch, and wrote copiously for the Southern Literary Messenger, and sometimes for the Atlantic Monthly. It was through the medium of the Messenger that he lodged his first deep and popular impression as a humorous writer. It may be questioned whether anything of a racier flavor, free from slang, yet fresh as dawn dew with idioms of the heart and hearth; whether anything of more sylvan depth and of more natural oddity and simplicity ever saw the light, than the "Letters of Mozis Addums to Billy Evans of Kurdsville," in which the society, the man-traps, and the wonders of Washington City are described by a rustic writer to a rustic friend. The correspondent is represented as visiting the capital to procure a patent for a machine of his invention, for executing his idea of perpetual motion. An amiable and virtuous Irish servant-girl rescues him out of a number of scrapes, and Addums ends by marrying her.

Soon after this performance, John R. Thompson, one of the best beloved of the sons of song, resigned the editorial chair of the Southern Literary Messenger, to become the editor of the Field and Farm, of New York. The very terms of the announcement signified to those who were anyway behind the scenes, that Dr. Bagby had virtually already succeeded to the tripod of the magazine from which no less a seer than Edgar A. 
Poe had once spoken. And so he had, as the titlepage of the next issue announced. Whatever the prestige with which he entered upon the discharge of his duties, the pressure and perplexities of the situation were all adverse. In other words, there could be at the South, as at that time, no purely literary work, or literary leisure, when the very air was saturated with politics, and, no more than religion, could literature resist its access. Yet the volume of the Messenger for 1860 will be found to contain critical and creative work in quite a notable degree, and of a high order of merit. The romaunt of "Blue Eye and Battlewick," a Christmas story, to some extent, perhaps, an unconscious imitation of Dickens, but altogether sui generis, and like the echoes in Ireland and in Ossian, which repeat what they hear with variations of their own-ran through this volume of the Messenger, in five instalments: January-May. Many minor sketches accompanied the unfolding of the "Blue Eyes" story, and the editorial department was always kept full and fresh. In it Dr. Bagby defended the rights of the South, till, high over the noises of the press and the clamor of orators, rose suddenly and rudely the sharp thunder from Sumter, and the war was flagrant. Though wholly unfitted, physically, Bagby entered the ranks as a private, and was found with the earliest troops who were assembled at Manassas. There, fortunately, he soon attracted the attention of General Beauregard's chief of staff, and was, in part, relieved of duties of which he was incapable, by being detailed for clerical work at head-quarters. It was not long, xxiii 
however, before his health proved inadequate for even this service, and he was given a final discharge.

Resuming his profession, he sang the songs of a nation, while others fought its battles and made its laws.

Through every difficulty and over every obstaclethe scarcity of paper and skilled labor, the absence of competent assistance of every kind, and the everdwindling Confederate ration-Dr. Bagby sustained the Messenger till its proprietorship changed, in 1S64, and then laid down the burden, having fought the good fight with unfaltering courage.

Besides the magazine, Dr. Bagby performed, during the war, a vast amount of literary and journalistic work. He was the correspondent, at the Confederate capital, of every Southern paper that could secure the favor of being represented by him: the Mobile Register, the Memphis Appeal, the Columbus, Ga., Sun, the Charleston Mereury, and others, besides his regular service for some years as editorial contributor to the Richmond Whig, of which his friend McDonald had become the editor. His boldness of comment on the course of events within the ill-starred Confederacy led him to write occasionally for the Richmond Examiner, though he did not approve, in general, its reckless method. His intercourse with the editor of the $E x$ aminer gave him material for the sketch published shortly after the war, entitled, "John M. Daniel's Latch-key." Besides his work on the papers mentioned, Bagby wrote brilliant articles for the Southern Illustrated News, and was every way useful. 


\section{GEORGE WILLIAM BAGBY}

The success of Dr. Bagby before and during the war well justified his seeking to pursue in New York a journalistic and literary eareer. His disability in this line, by reason of the loss in part of his eyesight, induced him to enter the lecturing field, in which a rich reception and a bountiful harvest awaited him. More than that, his choice of a new profession involved his return to Virginia, now made doubly dear to him in that, in 1863, he had espoused Miss Parke W. Chamberlayne, of Richmond, daughter of Dr. Lewis Chamberlayne, who represented in her own person at least two of the noble lines of Normans whose shields are suspended in Battle Abbey-the lines of Chamberlayne and of D'Aubigny (Dabney)-illustrious English and Virginian lineages. Let the laurel of honor to this lady of love and grace be deferred to a later page, while we deal at present with the fortunes of the lecturer, and the turn that was given to the tide of his life by this new venture.

The profession was not wholly fresh to him, as he himself relates. "Previous to the war he had been fairly successful with his lecture entitled 'An Apology for Fools,' but in the winter of 1865-6 his lecture on 'Bacon and Greens or the Native Virginian' fairly took the City of Richmond by storm, and was as great a success throughout Virginia and Maryland."

His next essay, "The Disease Called Love," is perhaps the most popular of all his lectures, with old and young. In addition to these was another lecture, cntitled "Women-Folks," and one on the "Virginia Negro," which was only faulty in its depth of truth. 
Its delivery in New York at once drew the partisan line, which renders fair judgment not only impossible but undesirable. Nobody really wanted to know the actual state of the case, and the preacher of truth allowed himself to be discouraged and repulsed by the first chill reception which he suffered.

In 1869 , G. C. Walker was elected Governor of Virginia as a liberal Republican; and under his administration and that of his successors, Gen. James L. Kemper and Col. F. W. M. Holliday, Hon. James McDonald served as Secretary of State. Faithful to the tartan blood which he bore, and true to the obligations of old times; secure too in the sense of the eminent fitness of his friend, General McDonald appointed Dr. Bagby assistant secretary, and as such custodian of the State Library. Never was there loyalty to a dead cause such as his since the days of the Scotch Jacobites; his heart was ever with the "Charlie over the water," when indeed there was no king except in his thought. And the aching knowledge that he loved a dead dream weighed on him always, and then broke his heart; and he left other less consecrated men to face the new world of untried and raw conditions, while to himself, as when the "whole round table was dissolved," was given of God the freedom of the blackstoled barge, and the weeping queens, and the comfort of green valleys and deep peace in the Isle of Avillion, beyond the seas.

Little remains to be said of his life. The fact of its incessant activity is told in the mere catalogue of the papers to which he contributed and the lectures he xxvi 
delivered. One of the very best and brightest of his creations, about this time, was his satire entitled "What I Did with my Fifty Millions," an evolution, wholly original withal, from the lamp of Alnaschar and the milkmaid of Esop-or of Noah Webster. I say satire, not ignorant that the word is not adequate nor accurate, for it was part of the genius of our friend that he created a school of style and theme in letters all his own, with which the terminology of rhetoric has not much to do.

Another very happy idyl was his "Reminiscences of Canal Life," in which his loyal love of nature finds an expression as strong and yet simple as the mother longing of a lost child. In Goethe's "Renunciants," the highest culture was imaged by the figure which gazed with folded palms upon the ground. Such was Bagby's reverence, and such his rapt contemplation of the garment of God, which shows, through the drapery of rock and rill, and cloud and storm and mountain, the august proportions of the Eternal. Happy was he, after all experience of doubt and darkness, to find at last in these vast folds of form the evidence and expression of a Father of love and light, who comforts and helps the weak-hearted, and raises up those who fall. In the peace of this faith he fell asleep, like Stephen, while "all that sat in the council, looking steadfastly at him, saw his face as it had been the face of an angel."

During this period he composed and delivered several of his best lectures-“"The Old Virginia Gentleman" and "The Virginia Negro." The latter was intended for delivery North; but he found, after a xxvii 
brief but sufficient experience, that the North thought they knew more of the negro than he did. Returning, he wrote the most merry and exquisite of all his creations-" Meekinses' Twinses"- - a fiction founded upon fact. Mr. Meekins acquired in a week as wide an acquaintance as Mr. Addums in a dozen years; and the feed sto' in Rocketts had as good a title to a place in the limbus of genius as the "Old Curiosity Shop" or the City Mildendo. Hereabouts also belongs the sketch which has given him his widest and most graven fame-the sketch of "Rubenstein at the Piano"-which Mr. Watterson has admitted into his compilation of Southern humor, and which is found already in many "Readers." I am told it has been translated into a German musical magazine. It has always reminded me, in structure-though the themes are wide enough apart-of the "Dream Fugue" attached to De Quincey's "Vision of Sudden Death."

After these writings, Dr. Bagby made for the State newspaper, then edited by Capt. John Hampden Chamberlayne (brother of his wife, and one of the brightest and best of the knights whose accolade was given on the two fields of battle and labor), a trip through Virginia, describing each stage in letters, whose power of paint and of thought surpassed any production of the kind in the history of Virginian journalism.

A like series of letters, entitled, "New England Through the Back Door," written for the Baltimore Sun, gave us a Yankee-land more gracious, fresh, and genial even than the "Hills of the Shatemuc." Then 
came desultory writing for many papers. Mr. A. McDonald, editor of the Lynchburg News, was again one of his generous friends to the last; the Philadelphia Weekly Times published one of his papers; and his last composition appeared in Harper's Magazine.

After that, death; not all at once, but by gradual stages, as of a siege. He sought the relief of the Hcaling Springs in vain, and then, in August of '83, desolate but not despairing, he turned home to die.

The foregoing pages have been written in vain if they have not conveyed some sense of the writer's appreciation of Dr. Bagby's genius and moral greatness. "There is no man left in Virginia fit to lift the lid of his inkstand," wrote Dr. Lafferty of him-a true saying. "Never in Virginia letters shall we see his like again," wrote John Esten Cooke. All pens, great and small, sought, with the piety of "Old Mortality," to deepen the inscription of love and praise on his tomb, and to clear off the grass and weeds. The most faithful and beautiful of the tributes paid to his memory was woven from the heart through the pen of his lifetime friend, Gen. James McDonald, who, true to the habit of his Highland blood, was the well-trusted comrade of thirty odd years, and one of the executors of his literary remains.

Long time as death was known to be approaching, its final access was a surprise at last. "Death will not be fooled," he had written in "Blue Eyes." "He will have his dues. Preparation avails nothing. Rem tetigit ac $\hat{u}$. Aye, he does touch sharply, as with a poisoned thorn, piercing to the core. When no answer, xxix 
be it ever so faint and feeble, comes from the lips that have thanked us; when no turning of the eye repays in grateful light the hands that smooth the sunken pillow; when all is still there, and no sound shall be there forever-forever!-how burst the fountains, how the waters are unsealed, as though never a thought of that hour of anguish had warned us of its coming.

The Virginia of the future may be grander, richer, and stronger than the Virginia, "immaculate and immortal," which his love and imagination touched into all the lines and colors of ideal perfection; but it cannot ever and forever be the same Virginia, the mother and nurse in classic and Christian greatness of Washingtons and Lees, of Stuarts and Rodeses, and of children humbler in birth and state, but all as dutiful and dauntless. Whatever there was that was brightest and sweetest in the older civilization, in what he queerly called the Virginia of the "spring and gourd" period, whose seedy relics are even as an offence in the eyes of the new generation; whatever is truest and best and bravest that survives among the most potent factors and kindliest influences of the Virginia that is yet to be, will owe its survival and its vitality to the labor and love of one to whom-more fitly than to most-we may apply the sad consolation, "After life's fitful fever he sleeps well."

Edward S. Gregory. 


\section{I}

\section{THE OLD VIRGINIA GENTLEMAN}

HIS house was not jammed down within two inches 1 and a half of "the main, plain road." Why! He held, as his father did before him, that it was immodest to expose even his house to the public gaze. Perhaps he had that lack of curiosity which, the newspaper men tell us, is characteristic of the savage-most of us, you know, are descended from Pocahontas-and, at all events, it would never do to have his head-quarters on the very edge of a plantation of one thousand or two thousand acres.

What was there to see on the main, plain road? Nothing. Morning and evening the boys dashed by on their colts, hurrying to or from the academy, so called. On Sundays, carry-alls, buggies, and wagons, filled with women-folk and children, in split-bottom chairs, wended their way to Mount Zion, a mile or two further on in the woods. Twice a week the stage rattled along, nobody inside, a negro in the boot, the driver and the negro-trader, both drunk, on top. Once a month the lawyers, in their stick-gigs or "single-chairs," and the farmers on their plantation mares, chatting and spitting amicably, with switches poised in up-and-downy elbows, jogged on to court. And 
that was all that was to be seen on the main, plain road, except the doctor and the deputy-sheriff, with their leggings and saddle-bags.

Tramps there were none, unless you call the county idiot, who stalked barefoot through the winter snow, fanning himself industriously the while with a turkeywing fan, a tramp. Once a year the pedler, with his pack, or the plausible oil-cloth table-cloth man, put in an appearance; and that was literally all. Why, even the hares played in the middle of the lonesome road! And yet there was a life and animation along the county roads, especially about the country taverns, in the good old days (they were good) which we who remember them sadly miss in these times of rapid railroad transit.

A stranger would never dream that the narrow turning out of the main road, scarcely marked by a rut, led to a habitation better than a charcoal-burner's shed. But the drivers of the high-swung, bug-back family carriages of the period knew that turning "mighty well." So did many gentlemen, old and young, in all parts of the commonwealth. "Oaklands," "Bellefield," “Mount Airy," whatever it might be named, was the half-way house to "Cousin 'Tom's," "Uncle Randolph's," or “grandpa's," twenty or thirty miles farther on. Also it was a convenient place to spend the night and mend the high-swung bug-back from Alpha to Omega when on your way to the White Sulphur, Richmond, or anywhere. Truth to tell, there was no getting around it; it drew you like a magnet. 
And whenever the road was adorned by a whitehaired, florid-faced gentleman astride a blooded horse, with his body-servant in charge of his portmanteau following at respectful distance behind, that party, you may be very sure, turned off the main, plain road and disappeared in the depths of the forest. Colonel Tidewater had come half the length of the State to try a little more of Judge Piedmont's Madeira, to know what on earth induced Piedmont to influence the governor in making that appointment, and to inquire if it were possible that Piedmont intended to bring out Jimson-of all human beings, Jimson!for Congress?

"Disappeared in the depths of the forest?" Yes. And why? Because there must be plenty of wood where there is no end of negroes, and fifteen or twenty miles of worm-fencing to keep in repair. So there was a forest on this side and on that of the Old Virginia Gentleman's home; sometimes on all sides; and the more woodland the better. How is a man to get along without clearing new ground every year? The boys must have some place to hunt squirrels. Everybody is obliged to have wild indigo to keep flies off his horse's head in summer. If you have no timber, what becomes of your hogs when you turn them out? How about fuel? Where is your plank to come from, and your logs for new cabins and tobacco barns? Are you going to buy poles for this, that, and the other? There's no use talking-negroes can't be healthy without wood, nor enjoy life without pine-knots when they go fishing at night. 


\section{THE OLD VIRGINIA GENTLEMAN}

Pleasant it was to trot through these forests on a hot summer day, or any other day, knowing what was to come at your journey's end. Pleasant, too, to bowl along under the arching boughs, albeit the ruts were terrible in places, and there were two or three immemorial holes, made by the butts of sawlogs (you could swear that the great mark in the centre of the road was the tail-trace of an Iguanodon, or some other Greek beast of prehistoric times)two or three old holes, that made every vehicle, but chiefly the bug-back carriage, lurch and careen worse than a ship in a heavy sea.

But these were useful holes. They educated the young negro driver, and compelled the old one to keep his wrinkled, mealy hand in. They toned, or rather tuned up, the nerves of the young ladies, and gave them excuse for uttering the prettiest shrieks; whereat the long-legged cousin, leaning to the left at an angle of ninety degrees, with his abominable red head forever inside the carriage window, would display his horsemanship in the most nimble, overaffectionate, and unpleasing manner-unpleasing to the young gentleman from the city, who was not a cousin, did not want to be a cousin, wasn't a bit proud of riding, but had "some sense of decency, and really a very high regard for the sensibilities of the most refined ladies in the whole State of Virginia, sir!" Many were the short but fervent prayers ejaculated by the old ladies in consequence of these same holes, which came to be provocatives of late piety, and on that account were never molested; and they were 
prized beyond measure by the freckle-face ten-yearold brother, who, standing up behind and hanging back by the carriage-straps, yelled with delight every time the bug-back went "way down," and wished from the very bottom of his horrid boy's heart that "the blamed old thing would bust all to flinders and plump the whole caboodle smack into the middle of the mud puddle."

Colonel Tidewater declared that Piedmont's forest road was the worst in the world, and enough to bring in jeopardy soul as well as body; to which Piedmont hotly replied that a five-mile stretch in August through the sand in Tidewater's county was eternity in Hades itself.

The forest once passed, a scene not of enchantment, though contrast often made it seem so, but of exceeding beauty, met the eye. Wide, very wide fields of waving grain, billowy seas of green or gold, as the season chanced to be, over which the scudding shadows chased and played, gladdened the heart with wealth far spread. Upon lowlands level as a floor, the plumed and tasselled corn stood tall and dense, rank behind rank in military alignment-a serried army, lush and strong. The rich, dark soil of the gently swelling knolls could scarcely be seen under the broad, lapping leaves of the mottled tobacco. The hills were carpeted with clover. Beneath the tree-clumps, fat cattle chewed the cud or pcaceful sheep reposed, grateful for the shade. In the midst of this plenty, half hidden in foliage over which the graceful shafts of the Lombard poplar towercd, with 
its bounteous garden and its orchards heavy with fruit near at hand, peered the old mansion, white, or dusky red or mellow gray by the storm and shine of years.

Seen by the tired horseman, halting at the woodland's edge, this picture, steeped in the intense, quivering summer noonlight, filled the soul with unspeakable emotions of beauty, tenderness, peace, home.

"-How calm could we rest

In that bosom of shade, with the friends we love best!"

Sorrows and cares were there-where do they not penetrate? but oh! dear God, one day in these sweet, tranquil homes outweighed a fevered lifetime in the gayest eities of the globe. Tell me nothing; I undervalue naught that man's heart delights in; I dearly love operas and great pageants; but I do know-as I know nothing else-that the first years of human life, and the last, yea, if it be possible, all the years, should be passed in the country. The towns may do for a day, a week, a month at most; but nature, mother nature, pure and clean, is for all time; yes, for eternity itself. What think you of heaven? Is it a narrow street, packed full of houses, with a theatre at one end and a beer saloon at the other? Nay! the city of God is under the trees and beside the living waters.

These homes of Virginia are ruins now; not like the ivied walls and towers of European lands, but ruins none the less. The houses, indeed, are still there, little changed, it may be, as to the outside; but the light, the life, the eharm are gone forever. "The soul is fled." 
About these Virginia homes there was much that was unlike the houses I have seen in the more populous States of the North and in Canada. A Soutilerner travelling through central Pennsylvania and western New York to the falls of Niagara, and thence down the St. Lawrence, is painfully impressed by the scarcity - the absence, one might say-of human beings around the houses and in the fields. There are no children playing in the cramped-up yards. The few laborers in the narrow fields make but a pitiful show, even at harvest time. The farms have a deserted look, that is most depressing to one accustomed to the sights and sounds of Virginia country life. For thirty miles below Quebec I watched the houses that thickly line the verdant river banks, but saw no human being-not one. The men were at work in the villages, the women were at the wash-tubs or in the kitchens; and as for the children, I know not where they were.

How unlike Virginia of the olden time! There, people were astir, and something was always going on. The young master, with his troop of little darkies, was everywhere-in the yard, playing horses; in the fields, hunting larks or partridges; in the orchards, hunting for birds' nests; at the barn, sliding down the straw stacks; in the woods, twisting or smoking hares out of hollow trees; in the "branch," fishing or bathing (we call it "washing" in Virginia); in the patch, plugging half-ripe watermelons; or elsewhere, in some fun or mischief. "Young Mistiss," in her sun-bonnet, had her retinue of sable attend- 
ants, who, bare-armed and bare-footed, accompanied her in her rambles through the garden, the open woodland near the house, and sometimes as far as the big gate. By the way, whenever you heard the big gate slam, you might know that "comp'ny" was coming. And comp'ny was always coming - beaux to see the grown-up girls, neighbors, friends, strangers, kinfolks -no end of them. Then some comely negro woman, with bright kerchief on her head, was ever passing to and fro, on business with her mistress; and few days passed that did not witness the "drop-shot gang" of small Ethiops sweeping up the fallen leaves that disfigured the broad yard.

Some one was always coming or going. The gig, the double buggy, the carry-all, the carriage, were in constant use. Horses, two to a dozen, were seldom wanting at the rack, and the boy of the family was sure to be on the horse-block, begging permission to "ride behind," or to carry the horse to the stable. Bringing in breakfast, dinner, and supper, and carrying the things back to the kitchen, kept three or four servants busy from dawn till long after dark. The mistress had a large provision store at the smoke-house, where there was much to do every day except Sunday. So, too, with the dairy. From the rooms set apart for weaving and spinning came the tireless droning of wheels and the clatter of looms-wonderful machines, that delighted the knots of white and black children gathered at the open doorways. How gracefully Aunt Sooky stepped back and forth with her thread, as it kept growing and lengthening on the spindle! Why, I can 


\section{THE OLD VIRGINIA GENTLEMAN}

smell the wool-rools now, and see the brooches, and the shucks on which they were wound!

These were the scenes and occupations that gave life to the house. In the fields, from the time that the gangs of ploughers (we never called them ploughmen), moving steadily en echelon, turned up the rich sod, until the wheat was shocked, the corn laid by, the tobacco planted, suckered, primed, topped, cut, and hung in the golden sunshine to cure, there was something perpetually afoot to enliven the plantation. But who shall tell of harvest-time, when the field fairly swarmed with cutters, the binders, the shockers, the gleaners, all agog with excitement and joy? A murrain on your modern reapers and mowers! What care I if Cyrus McCormick was born in Rockbridge County? These new-fangled "contraptions" are to the old system what the little, dirty, black steam-tug is to the three-decker, with its cloud of snowy canvas towering to the skies - the grandest and most beautiful sight in the world. I wouldn't give Uncle Isham's picked man, "long Billy Carter," leading the field, with one good drink of whiskey in him-I wouldn't give one swing of his cradle and one "ketch" of his straw for all the mowers and reapers in creation.

But what was the harvest-field compared to threshing-time at the barn? Great goodness alive! Do you all remember that huge $\operatorname{cog}$-wheel aloft, and the little cog-wheels, that big post that turned 'round, the thick shafts-two horses to a shaft; eight or ten horses to a machine-(none of your one-horse, out-o'-door concerns-this was under a large shed, close to the barn), 
and how we sat on those shafts, and how we drove those horses, and hollered at 'em, and how the dust flew, and what a glorious, glorious racket, hubbub, and confusion there was? Surely you do.

Then came beating-cider time. Bless me! how sick "us boys" used to get from drinking sweet cider and eating apple "pommels"! You recollect the ciderpress? None of your fish-traps, cut in two, and set on end, with an iron crank, but a good, honest beam, a foot and a half thick, and fifteen to twenty feet long, jobbed into a hole cut clean through a stout oak tree, with a wooden trough holding half a ton of rocks, and an affair with holes and pegs, to regulate the prizing. Now that was a press, a real press-not a gimcrack. Don't ask me about corn-shuckings. It would take a separate lecture to describe them; besides, you already know more about them than I can tell you.

If the house, the barn, the fields were alive, so also were the woods. There the axe was ever plying. Timber to cut for cabins (the negroes increased so fast), for tobacco houses and for fuel, new ground to clear, etc., etc. The crack of the gun was heard continually - the boys were shooting squirrels for Brunswick stew -and when the wild pigeons came, there was an endless fusilade. As for sports, besides squirrels, 'coons, and 'possums, there were partridges, robins, larks, and even kildees and bull-bats, for shooting; but far above all these, was the fox-hunt. Ah! who can ever forget it? When the chase swept through the forest and across the hills, the hounds and the beagles in full, eager, piercing, passionate ery, making music for the very 


\section{THE OLD VIRGINIA GENTLEMAN}

gods and driving the huntsmen stark mad, what were staked and ridered fences, tangled underwoorl, gullies, ditches, banks that were almost precipices, what was life, what was death to the young fellow just out of college, that glorious music ringing in his ears, his horse, a thing all fire and steel, going under him like a thunderbolt, and the fox not five hundred yards away? Tell me Southern country life was monotonous! Bah!

Why, something or somebody was forever stirring. In the dead of night, hours before daybreak, some old negro was eternally getting up to chunk his fire, or to cut another stick or two. In the dead of winter, the wagons were busy hauling wood, to keep up the grand old fires in the big old fireplaces. And at the worst, the boys could always jump a hare out of a briar-patch, and then such "hollering," such whistling, such whooping, such calling of dogs:- "Here, here, here! who-eet! whoop!" as if Bedlam had broke loose.

Of church-going on Sunday, when the girls kept the carriage waiting; of warrant-tryings, vendues, election and general muster days, of parties of all kinds, from candy-stews and "infairs" up to the regular country balls at the county seat, of fun at negro weddings, of fish-fries, barbecues, sailing-parties, sora and duck shooting, rides and drives-the delights of Tidewater life-of dinings in and dinings out, of the bishop's visit, of company come for all day in addition to the company regularly domiciled for the week, month, or half-year, I need not speak at length. Country life in Virginia tiresome! You are crazy! 
The habitation of the old Virginia gentleman-house is too short a word to express it-always large enough, however small it might be, was sometimes stately, like the great square house of "Rosewell," and others I might name. As a rule, to which, indeed, there were many exceptions, it was neither planned nor built-it grew: and that was its great charm. To be sure, the main structure or body of it had been put up with an eye not to convenience but to elbow-room and breathing spacewithout which no Virginian can live. But in course of time, as the children came along, as the family connections increased, and as the desire, the necessity in fact, of keeping a free hotel grew upon him, the old gentleman kept adding a wing here and tacking a shed room there until the original building became mixed up, and, as it were, lost in the crowd of additions. In cold weather the old house was often miserably uncomfortable, but at all other times it was simply glorious. There was, of course, a large hall or passage, a parlor and dining-room, "the chamber" proper for the old lady and for everybody, and a fine old-time staircase leading to the guest-chambers, but the rest of the house ran mostly into nondescript apartments, access to which was not always easy. For the floors were on different levels, as they ought to be in an old country house. Fail to step up or down at the proper time, and you were sure to bump your head or bruise your shins. Then there were dark closets, cuddies, and big old chests that came mayhap from England, say nothing of the garret, full of mystery, that stretched the whole length of the house. Here was romance for child- 


\section{THE OLD VIRGINIA GENTLEMAN}

hood-plenty of it. These irregular rooms, two steps up and three down before you got fairly into them, teemed with poetry; but your modern houses, with square rooms all on a dead level, are prosaic as drygoods boxes.

A fine old house it was to play hide-and-seek in, to romp with the girls, to cut all sorts of capers without disturbing the old folks. Then these dark passages, these cuddies and closets, that big garret, never failed to harbor some good-natured old hip-shot fool of a family ghost, who was everlastingly "projicking" around at night, after the girls had quit their talk, making the floors crack, the doors creak, and whispering his nonsense through the keyhole, as if he coull scare you or anybody else! To modernize the old Virginian's house would kill that ghost, and if it be a crime to kill a live man, what an enormity it must be to kill one who has been dead a hundred years, who never harmed a living soul, and who, I suspect, was more fretted than sorry when the young ones would persist in hiding their heads under the bedclothes for fear of him! "You little geese! it's nobody but me," and "whish, whish, whish," he would go on with his idiotic whispering.

The heavy, dark furniture; the huge sideboard; the quaint solid chairs; the more common article, with spraddled legs, scooped seats, and stick backs; the diamond-paned book-case; the long horse-hair sofas, with round tasselled pillows, hard as logs of ebony, with nooks to hide them in; the graceful candle-stand; the gilt mirror, with its three compartments; the carved 
mantel, so high you could hardly reach the silver candlesticks on its narrow top; the bureaux, with swinging brass handles; the dressing-tables; the high-post bedstead, with valance and tester; the-

But stay! it suddenly and painfully occurs to methere are grown-up men and women actually here, in this room, immortal beings, who never laid eyes on a bed-wrench and pin, and who do not so much as know the meaning of cording a bed! Think of it! Yet these people live on. Ah me! the fashion of this world passeth away!

The massive dinner table, never big enough to hold all the dishes, some of which had to go on the hearth to be kept warm; the old-time silver, the heavy cut glassware, the glass pitcher for the thick, rich milkhow it foamed when they "poured it high!"-the Canton china, thin as thin biscuit; the plainer blue dinner set, for every-day use, with the big apples on the little trees, the blue islands in a white sea, the man or woman that was always going over that short bridge, but stopped and stood provokingly in the middle-how they all come back to you! But I "lay" you have forgotten the bandboxes. Think of that again! Bandboxes have fled away from the face of this earth, but not to heaven; for they were much uglier than any sin I'm acquainted with. I recall the very pattern of them-the red brick houses, with many windows, the clumsy trees, and that odd something, more like a pile of rocks than an elephant, but spouting clods of water, like an elephant who had got drunk on mud.

When you were a boy, did you sleep in a low-pitched, 
dormer-windowed room, with two little gable windows that looked out upon a narrow-necked chimney, just where the neck ended and the shoulder began? You didn't? Then I pity you; you must have had a mighty poor sort of boyhood. Why, I can see the moss growing on that chimney, can see how very thick the old thing is at the bottom, and, by George! there is the identical old toad (frog, we call him) that pops out every night from the slit in the wall at the side of the chimney. How well he looks! hasn't changed a hair in forty years! Come! let's "ketch" some lightning-bugs and feed him, right now.

Surely, you hav'n't forgotten the rainy days at the old country house? How the drops kept dropping, dropping from the eaves, and popping, popping up from the little trough worn into the earth below the eaves; how draggled and miserable the rooster looked, as you watched him from your seat in the deep window-sill; and how (tired of playing in-doors) you wondered if it would never, never stop raining? How you wandered from room to room, all over the house, up stairs and down stairs, eating cakes and apples, or buttered bread and raspberry jam; how at last you settled down in the old lady's chamber and held a hank till your arms ached, and you longed for bedtime to come? If you have never known such days, never seen the reel the hanks were placed on, nor the flaxwheels that clacked when the time came to stop winding, then you have neither seen nor known anything. You don't know how to "skin the cat," or to play "Ant'ny over"; you don't know how to drop a live 
coal in a little puddle of water, and explode it with an axe; you "don't know nothin" "-you have never been a Virginia boy.

Yes, your arms ached, poor little fellow, pining for out-door fun; they were sure to ache if you held the hank for Miss Mehaly Sidebottom, the poor lady who had lived in the family time out o' mind; but if you held it for a pretty girl - and what Virginia gentleman's house was without one-two-three-half a dozen of them? - then your arms didn't give out half so soon, and you didn't know what it was to get hungry or slcepy. When you grew older, a rainy day in the country was worth untold money, for then you had the pretty girl all to yourself the livelong day in the drawing-room. What music the rain made on the roof at night, and how you wished the long season in May would set in, raise all the creeks past fording, wash away all the bridges, and keep you there forever.

And such girls! They were of a piece with the dear old house; they belonged to it of right, and it would not, and it could not, have been what it was without them. Finer women, physically, I may have seen, with much more bone, a deal more of muscle, and redder cheeks; but more grace, more elegance, more refinement, more guileless purity, were never found the whole world over, in any age, not even that of the halcyon. There was about these country girlsI mean no disparagement of their city sisters, for all Virginia girls were city girls in winter and country girls in summer, so happy was our peculiar social system-there was about these country girls I know not 


\section{THE OLD VIRGINIA GENTLEMAN}

what of sauce-the word is a little too strong-of mischief, of spirit, of fire, of archness, coquetry, and bright winsomeness - tendrils these of a stock that was strong and true as heart could wish or nature frame; for in essentials their character was based upon a confiding, trusting, loving, unselfish devotion - a complete, immaculate world of womanly virtue and home piety was theirs, the like of which, I boldly claim, was seldom approached, and never excelled, since the Almighty made man in his own image.

What matter if it rained or shone, so you spent your time with girls like these? And if one of them chanced to be a cousin - everybody has cousins-then there was no help for you; literally none-

"Did you ever have a cousin, Tom?

And did that cousin sing?

Sisters we've had by the dozen, Tom-

But a cousin's a different thing!"

I believe you. A cousin, a real female cousin, I take to be the invention of the de'il himself-his pet bit of ingenuity. She makes you all but crazy to marry her, then she won't marry you, never had the remotest idea of marrying you (says so anyhow), and you know you oughtn't to marry her even if she were willing; and-where are you? There's not a man of us who has not been robbed of his senses by one or more of these beautiful witches, not one of us who does not recall the time when

"Half dying with love,

We ate up her glove

And drank our champagne from her shoe!" 


\section{THE OLD VIRGINIA GENTLEMAN}

And a little "teenchy" bit of a shoe it was, toowhite kid. She never knew who stole it, and you have had it hid away these twenty years, although you are married. I know you, sir.

Are there any such girls nowadays, I wonder? I trust so, indeed. The archness and coquetry in the girls of whom I have been speaking were but charming arabesques upon Damascus steel, metal of proof, whose mortal sharpness, bitter and keen, he was sure to feel, and quickly too, who dared to come too near. But since the war, I am told, a change has come to pass, and approaches, impossible in purer days, are allowed. Is it so? Then are we lost indeed! It cannot be so; but if it be so in part only, who is to blame? Are not you, young gentleman? Hold off, sir; stand back, I say; lay not so much as a finger-tip lightly upon her, for she is sacred. If she be not yours, she is your brother's; and if your own, will you harm ever so little her whom you intend to make your wife? Oh! wait, do but wait. In the hallowed stillness of your bridal eve, ere the guests have all assembled, lift up to yours the fair pale face, love's perfect image, and you shall see that vision to which God our Father vouchsafes no equal this side the jasper throne-you shall see the ineffable eyes of innocence entrusting to you, unworthy, oh! so unworthy, her destiny through time and eternity. Inhale the perfume of her breath and hair, that puts the violets of the wood to shame; press your first kiss (for now she is all your own), your first kiss upon the trembling petals of her lips, and you shall hear, with ears you knew not that you had, the 
silver chiming of your wedding bells far, far up in heaven.

As were the girls, so was their mother; only of a type, if possible, still higher; for I can but think that, since the Colonial and Revolutionary days, each generation has shown a slight falling away from those grand models of men and women who really existed in Virginia, but whom we have come to look upon almost as myths. That the mother was lovelier or more lovable than her daughters, I will not say. That she was purer, tenderer, truer, sweeter, I will not say; but certainly there was about her a dignity, a repose, an impressiveness-at all events, a something that one missed in the beautiful maidens who grew up around her. Perhaps it was the effect of age. I know not; but I do know that, in some respects, her daughters were not quite equal to her.

Words fail to tell what the Virginia lady of the best type was. During the first decade of her married life, a part of each recurring winter was passed at the State capital or in Washington, and a part of each summer at the springs; she was at that time no stranger to the great cities and seasides of the North; and, in some instances (though these, to speak the truth, were very rare), she had travelled abroad, and knew the delights of European capitals. But now, for many years, her whole life had been spent at home. She was much too busy to leave it. The bodily and spiritual welfare of too many human beings depended upon her gentle presence, her bencficent guidance, to permit more than the briefest visit, once a year, to her 
aged parents. Retaining the grace, and, to some extent, the ease of manner, characteristic of her class and peculiarly her own in early womanhood, whilst moving in the brilliant throngs of cities and watering-places, and accustomed, as she had ever been, to receive and entertain the best people of her own and other States, there had nevertheless crept over her, in consequence, no doubt, of her long seclusion, an almost girlish shyness, a maidenly timidity, a little uncertainty as to herself, an absence of readiness and $a$ plomb, which were inexpressibly beautiful. The ways of the great world had ceased, long ago, to be her ways. She lived in a little world of her own. She cared not to keep pace with the fast-changing fashions, which, to her pure mind, were not always for the better. Her manner was not, in the usual sense, high-bred; for hers was the highest breeding, and she had no manner. But her welcome as you entered her door, and her greeting, meet her when you might, on the endless round of her duties, in-doors or out, was as simple and genial as sunshine, and as sweet as spring water. Full well she knew the seriousness of life. Over and over the cares and responsibilities of her station, as the mother of so many children, the mistress of so many servants, and the hostess of so many guests, had utterly overwhelmed her. Again and again had she been willing, nay glad -were it God's pleasure-to lay down the burthen that was too heavy for poor human nature to bear. To her own sorrows she added the sorrows of her friends, her neighbors, her dependents. Into how many negro cabins had she not gone, when the night 


\section{THE OLD VIRGINIA GENTLEMAN}

was far spent and the lamp of life flickered low in the breast of the dying slave! How often she ministered to him with her own hands! Thin hands, wasted with overwork-for she disdained no labor, manual or mental-I can see them now! Nay, had she not knelt by his lowly bed and poured out her heart to God as his soul winged its flight, and closed his glazed and staring eyes as the day was dawning? yet the morning meal found her at her accustomed seat, tranquil and helpful, and no one but her husband the wiser for her night's ministrations. What poor woman for miles around knew not the brightness of her coming? Some of her own children had been taken from herthat deep anguish! she knew it all-and the children of her neighbors, even the humblest, had died in her lap; herself had washed and shrouded them. To feed, to clothe, to teach, to guide, to comfort, to nurse, to provide for and to watch over a great household and keep its complex machinery in noiseless order-these were the woman's rights which she asserted, and there was no one to dispute; this was her mission, and none ever dared to question it. Mother, mistress, instructor, counsellor, benefactress, friend, angel of the sick-room! if ever I am tempted to call down the fire of divine wrath, it is upon the head of those (there have been such, incredible as it may seem), who have wilfully and persistently misrepresented this best and purest of God's creatures as the luxurious, idle, cruel, and tyrannical favorite of some Eastern harem. The arch-fiend himself could not have originated a slander more gross, more infinitely and detestably foul. 
My rambles before the war made me the guest of Virginians of all grades. Brightest by far of the memories of those days, that seem to have been passed in some other planet, is that of the Virginia mother, as I have so often seen her, in the midst of her tall sons and blooming daughters. Her delicacy, tenderness, freshness, gentleness; the absolute purity of her life and thought, typified in the spotless neatness of her apparel and her every surrounding, it is quite impossible to convey. Withal, there was about her a naïveté mingled with sadness, that gave her a surpassing charm. Her light blush, easily called up when her children rallied her, as they habitually would, about her old-fashioned ways and her ignorance of the world, was something never to be forgotten. Sunlight, flushing with faint rose-tints the driven snow, could scarcely more excite the rapture of admiration. Her pride in her sons, her delight in her daughters, her lowliness and her humility-for she was least among them all, and they were as yet too young and full of bounding life to revere and worship her as she deserved-who shall, who can fitly tell of these things?

When I think of the days that will come no more, I sometimes pass my hand quickly across my eyes, as one who wishes to brush away a vision, not because it is unpleasing, but simply because it is unreal. And in the solitude of my room I sometimes ask myself aloud, "Was this actually so? Did I live in those days? Isn't it a dream? Did I ever know such women? Is there not some mirage, some rosy but false light, thrown upon the picture as it appears in 
memory? It is very, very beautiful; but is it not of the fancy merely?"

No! blessed be the Giver of every good and perfect gift, the picture is not imaginary. It is real. These women lived. The most of us who are bearded men have seen them and talked with them; and some of you (alas! I am not of your number) remember with trembling and with tears that, long, long years ago, by the embers and low flames fluttering in the nursery fireplace, you knelt at the feet of such a woman, and while her soft hand rested on your head, said the little prayer her pure lips had taught you to pray. You called her mother. She was your mother.

How did these Virginia mothers and housekeepers manage to put things in order and keep them so exquisitely clean? That was always a mystery to me. "Servants," you say. Oh! yes! servants of course; but when servants have so many things to do, how is it that you never see them doing any one of them? If you lay awake all night long, you would, in some vague daybreak hour, hear a peculiar humping, rumbling noise, never heard north of the Susquehanna, which was occasioned, I am told, by a performance called "dry-rubbing." A graybeard Virginia boy told me only yesterday that riding on the scrubbing-brush, by squatting astraddle the brush and holding on to the long handle, was the best sort of fun. But by the time you got downstairs, noborly was to be seen, the floors were so slick that your neck was in danger, the silver candlestick, snuffers, and tray were spotless, so were the big brass andirons, so was the brass fender, and as 


\section{THE OLD VIRGINIA GENTLEMAN}

for the door-knobs, why, you could see your face in them any time; and a comical, big-mouthed, narrowforeheaded face it was, as every Virginia boy knows. Who did it? When? how? what for? I don't like things so terrifically clean-do you? One morning I did catch a girl coming out of the parlor with a bucket in her hand. She trembled like a guilty thing surprised, turned a little yellow, then blushed a reddish black, "curche'd," and said:

"I jes' bin clayin' de h'ath, sir."

What pleasure, what joy indeed, it was to visit a house over which one of these dear Virginia ladies presided! But what time of year was the best for your visit? Mortal man could never tell. There was the summer time, when you died daily of a surfeit of peaches and cream, and watermelons, tingling cold from the ice-house, all on top of your regular dinner; and somehow you never felt well enough to go bat-shooting with the boys about sundown, but did gather up strength enough to walk out with one of the girls, "it didn't matter which one," you said, and told a whopper when you said so. When night came, and the girls with their beaux were in the parlor, and the old gentleman was talking politics with his friends in the front porch, your energy increased. Without a thought of fatigue, you strolled under the manorial oaks-alone? no, not altogether alone. The incessant chatter of the katydids, and the active vocal correspondence of the frogs in the mill-pond and the creeks, made it certain that whatever you had to say would be heard only by-yourself? Yes, oh! yes. The drowsy tinkle of 
the cow-bells in the "cup-pen" smote softly on your ear. The switching of the whippoorwill mingled with the ululations of the half-scared negro, trudging homeward through the distant woods. Music from the open windows of the parlor, dipped in the perfume of flowers freshened by the night dews, lifted your soul into Elysium. But the voice of the lady in white, whose little hand rested on your arm, was sweeter than music and flowers combined.

(If, in the beautiful vista of life that opened then before you, a panorama-not seen distinctly, but apprehended by some fine lover-sense, unknown to ordinary mortals-if in that entrancing vista, a panorama of a possible "plantation and negroes," superadded to the young lady in the simple lawn dress, presented itself to you, ah! how could you help it? and what poor, but handsome and aspiring, young man will blame you? I certainly will not.)

But it was too sweet to last You didn't want to go in, not you, if it was midnight; but she made you go. Then came the unrepose in the lavendered bed, with the night-wind murmuring through the locusts and aspens, and the starlight spilling down from heavenwhere you cared not to go, yet awhile. No rest-for brain and heart were on fire with hopes and fears. No rest. The mocking-bird in the thorn-bush, for all his melody, was a nuisance; and that screech-owl in the old catalpa-how you would have liked to cut his throat, slowly, ever so slowly, with a dull case-knife! At last, consciousness melted away in to the paradise of dreams, and you awoke in the morning to find your 


\section{THE OLD VIRGINIA GENTLEMAN}

sweetheart fairer than the fleecy clouds and sweeter than the dew-washed roses.

On some accounts, the winter was even better than the summer for a visit to the old Virginia gentleman's home. There were more sports, Christmas parties, sleigh-rides, etc., and a different order of eatables and drinkables. But you devoured your lady-love, opposite whom the cunning waiter was sure to seat you. She was fatter, plumper, rosier, arm-fuller, warmer, impudenter, more mischievous, harder to catch, marriageabler, exceedingly much more to be desired in marriage, and everything more delicious than before. After breakfast, and such a breakfast, a ride on horseback was demanded by all the laws of digestion. Coming back at a flying gallop, she was apt to look something very like "yes," and put whip to her steed. Then came a race. Fox-hunting was a fool to it! Rather than fail in finding out the full meaning of that look, you would have killed the last one of her father's blooded horses. And when you caught up, oh! misery -the slippery $\operatorname{minx}$ had no affirmative for you, and you were "Mr. Impudence" for your pains. During the dance at night, she would give you, once an hour, a glance that was worth a king's ransom, and for the ensuing fifty-nine minutes and fifty-nine seconds was anybody's, everybody else's but yours. When the dancing was all over, and you had lingered at the foot of the staircase until you had well-nigh disgraced yourself, she would bid you good-night in tones that melted the very soul within you, dazzle you with her parting smile, and with the least little bit of a pressure of her 
tiny hand-“just enough to last you till morning," dart upstairs like a meteor.

The house was so full of company that you were sent out to the "office" in the yard, to stay with the boys. Time was when you asked nothing better; now, it was pure torture. The gabble of brothers and cousins about horses, dogs, guns, duels, "old Soc," "old Gess," "Schele," “Math,” getting "pitched," and the deuce knows what, disgusted and maddened you. You wanted to be alone with your celestial thoughts, and they wanted you to play euchre and drink whiskeypunch or apple-toddy. Idiots! You consigned them all, without scruple, to the bottom of the pit that has no bottom.

Ah me! those were days of the gods. Ask any man here of five and forty or fifty if they were not. Are there any such country homes left in Virginia? Is there even one such home? And do they have such delights in them now? I know not-I know not. I have outlived my time.

Carried away by recollections of the sweethearts of other days, the most of whom are grandmothers now, I seem to have forgotten the old Virginia gentleman himself. But I have not. It was necessary to give his surroundings. The large estate, the commodious house, the gentle wife, the sons and daughters, are but accessories of the principal figure. How shall I draw that true to nature? 'The popular idea of the old Virginia gentleman, even in our own minds, is about as correct as that of the typical Yankee, in bell-crown hat, 
swallow-tail coat, striped breeches, and short waistcoat. "Porte Crayon" has a picture of the old gentleman in "Virginia Illustrated"; Kennedy, in the "Swallow Barn," gives us another; and Elder in an admirable unfinished sketch of a country court-day in Virginia, furnishes a third. All agree in representing him as a stout, bluff, hearty, jovial old fellow, fond of juleps, horse-races, and "a little game of draw." This, to be sure, is one kind of Virginian, but not the typical kind, and by no means my ideal of an old Virginia gentleman. The truth is, there are several types, of which I distinguish five as more clearly marked than any others, viz.:

I. The one above given by Elder, Strother, and Kennedy.

II. A small, thin, sharp-featured, black-eyed, swarthy man; passionate, fiery indeed in temper; keen for any sort of discussion; profane, but swearing naturally and at times delightfully; hot, quick, bitter as death; magnanimous, but utterly implacable -a red Indian imprisoned in the fragile body of a consumptive old Roman.

III. A broad, solid, large-headed, large-faced, heavy, actually fat, deeply pious old gentleman-beaming with benevolence, the soul (and body, too!) of hospitality and kindness, simple as a child, absent-minded, unpractical to the last degree, and yet prosperous, because God just loves him-a dear, big, old father to everybody.

IV. A refined, scrupulously neat, carefully dressed, high-toned, proud, exclusive man; courteous, but somewhat cold; a judge of rare old wines and a lover of 


\section{THE OLD VIRGINIA GENTLEMAN}

then; a scholarly but dry and ungenial intellect; regardful of manners, a stickler for forms and social distinctions; fond of ancient customs, observances, and fashions, even to the cut of his clothes, which he would fain have made colonial; an aristocrat, born and bred, and never quite unconscious of the fact; a high type, one that commanded more of respect than love, but not, I think, the highest type.

V. Last and best comes the Virginian, less fiery than the old Roman-Indian, but of spirit quite as high; as courteous every whit as the aristocrat just named, but not so mannered; in culture not inferior to either, and adding thereto a gentleness almost feminine, and a humility born only, as my experience teaches, of a devout Christian spirit; a lover of children with his whole heart, and idolized by them in turn; knightly in his regard for womankind, in the lowest fully as much as in the highest sphere;--in a word, as nearly perfect as human infirmity permits man to be. An old gentleman of Maryland, himself a fine specimen of an admirable class, told me that what impressed him most in the Virginia gentlemen whom he met at the Springs and elsewhere, but more especially those who lived nearest him in the Northern Neck, was a humility amounting almost to forgetfulness of self, and yet joined to so perfect a knowledge of human worth that they could not and would not for an instant brook in others any disregard of those claims of simple manhood which instinct alone, and quite apart from education or social advantage, suffices thoroughly to teach.

In our college presidents and professors, our judges, 
senators, and other dignitaries, this lack of all pretence, and even of self-assertion, amounted, I have sometimes thought, to a fault. But better this, far better, when back of it lay all proper pride and personal courage, than the starchy vanity and conceit of priggish dons in other quarters of the globe.

It cannot be said that the last of the five classes just given is the typical Virginian. He, indeed, must be found by combining the separate types; but we have all seen specimens of this best class-few counties but contained one or more of them - and we do know that higher, nobler men never lived on earth.

No; to me the strangest possible of mistakes is to reckon the broad-waisted, jovial, rollicking English squire as the true Virginia type. The richest and most varied growths do not come out of cold white clay, but out of dark warm mould; and in the depths of the Virginia character there was ever a stratum of grave thought and feeling that not seldom sank into sadness and even gloom.

How could it be otherwise? Whether he lived on the banks of the great tidal rivers, and from his porches and windows was wont to watch the trees, faint and spectral, standing on the distant points far across the waves, with here and there a tired sail wandering away into the underworld, as if nevermore to return; or from his quiet home upon the hills of Piedmont saw, day after day from childhood, the mighty ridge, a rampart of Cyclopean steel, thrown all athwart the sky and fading in misty fire at the portals of the setting sun; or in the great valley beheld himself in an earthly 




\section{TIIE OLD VIRGINIA GENTLEMAN AND OTHER SKETCHES}





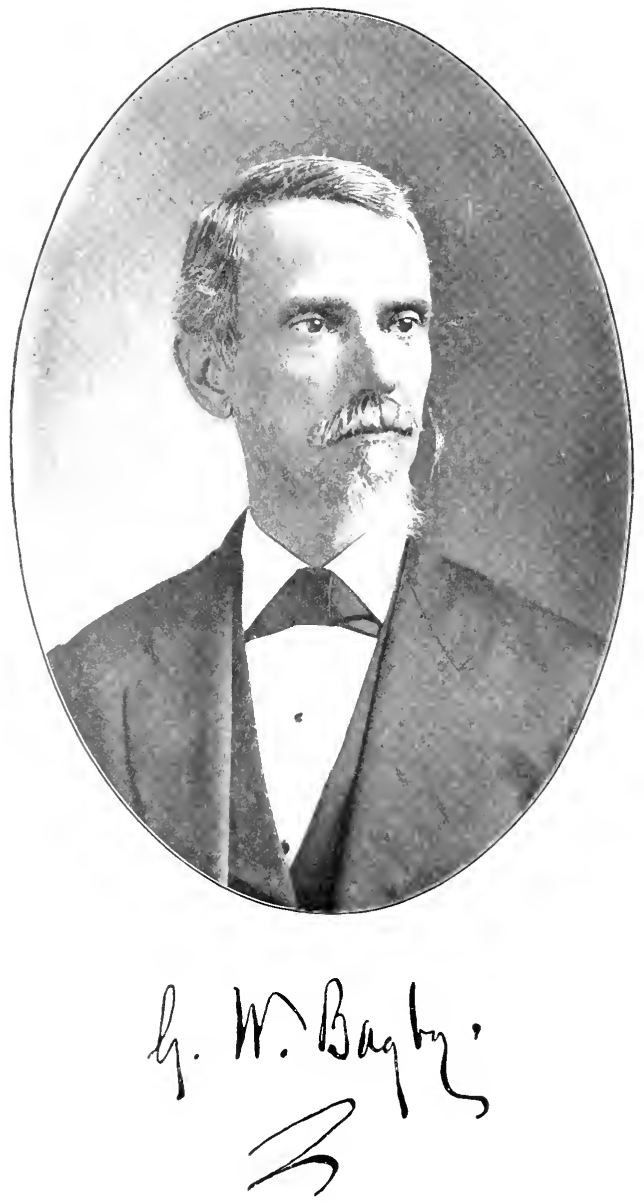
paradise, shut in between battlements built by the gods; or in the heart of the Alleghanies felt his young soul awed by the huge mountain forms, sphinxes as silent and much more vast than that of Egypt; live wherever he might in Virginia, the breadth and grandeur of these aspects of nature imparted their solemnity to him. His spirit was attuned from infancy to the moaning of the pines and the sea-like murmur of the wind in the forests around him; the desolation and barrenness of some of his neighbors' fields, wasted by bad tillage, left their impress upon him; insensibly his mind took the sombre coloring of these surroundings, and, however gay he might be at times, the warp of his life was always grave.

The profound sense of responsibility to his Maker added to this gravity. As husband, father, master, he felt to the full the weight of human duty. But high above them all rose his Roman sense of eivie obligation. Civis Americamus sum had in his day a meaning which seems lost in these later times. That meaning never left him. He could not forget it, and what is more, he did not want to. Often the presiding magistrate of his county; often, too, its representative in the legislature or in congress, he continued to direet its politics long after he ceased to take active part in them. His interest in publie affairs abated only with his breath. In addition to the many eares that grew out of this interest were the scarcely less heavy anxieties that pressed upon him as the friend, the counsellor, the fiduciary, the referee, and the arbitrator in the troubles and differences of opinion among his neighbors. IIis 
old escritoire or secretary was full of wills, deeds, notes of hand, and settlements of every kind. The widow and the orphan turned at once to him in all their trials. He never failed them-never.

His reading helped largely to increase the gravity due to all the trusts just named. The Federalist and other writings of Madison, the works of George Mason, Jefferson, and Calhoun, Elliott's Debates, the Greek and especially the Roman historians, the Letters of Junius and the speeches of Burke, made up the bulk of his library, and fed his mind with thoughts of that deepest and saddest of all problems-human government. If his neglect of scientific studies was, as I once held, simply shameful, it was, I am now willing and glad to believe, because science had not done in his day what indeed it has even now but imperfectly done-found its true objective in questions of government-the one paramount, underlying, and absorbing interest of the Virginian's life. His place on the border, in immediate sight of the national capital, the centre of power, would not permit him to forget the boding prophecies of Henry anterior to the adoption of the Constitution. In his ears rang ever the hollow murmur of that "fire-bell in the night" that affrighted the philosopher of Monticello. If, jealously guarding the only charter of rights left to him as a part of an everweakening minority, he insisted upon strict constructions, not of the letter only, but of the spirit of the organic law, and that were a fault, it was a fault from which there was no escape short of absolute surrender of his own liberty and that of the American people. 
His nice distinctions were drawn in defence of truth, of justice, of the good of the whole Union, nay, of all mankind; and he did well to split hairs when but a hair stood between him and degradation.

Could he for a moment fail to remember that the moral of the American Revolution, its sole value and excuse, was the right (supposed to have been achieved after ages of strife) of self-government, the remembrance was forced back upon him by continued assaults upon his character, his property, and all he held dear, by a horde of enemies ever increasing in numbers and bitterness. Yet it is contended by those who, pandering to the evil spirit of the hour, are more unwilling than unable to take in the full scope of this still important argument, that in grasping at shadows the Virginian lost the substance of power, and gave up for metaphysics a prosperity he might easily have retained. I deny it utterly.

Conceding for the moment that there can be lasting prosperity without good government, I point to the map. The configuration of the American continent, the north-eastward trend of the Atlantic coast, and the course of the Gulf Stream, which still carries the steamship in the very path of the sailing vessel, were not of the Virginian's making. Climate and soil, which made manufactures a necessity in New England, made agriculture a luxury to the Virginian. Yet he tried manufactures. How exceeding wise are the sons of to-day who twit their fathers with not having done this! Over and again the Virginian tried them, and over again was he crushed by associated capital. Immigration, 
determined in part by latitude and isotherms, but rigorously by proximity, ease and rapidity of access, the Virginian could no more control than he could control the motions of the heavenly bodies, yet despite immigration, dense population, and concentrated wealth, despite tariffs and protective laws devised for his ruin, he and his brethren of the South at the outbreaking of the late war were richer far, man for man, than their fellows of the North. Property was more evenly distributed, crime and pauperism were almost unknown, jails were empty, poor-houses empty, beggars were wonders, and social elevation, large areas considered, was incomparably superior. An old song, this. Yes, but it needs repeating when a Virginian declares that the Virginians of his own day lack "public spirit." Masterly as the oration at Randolph Macon undoubtedly was, and much needed as was the rebuke then administered to our overweening self-esteem, something may be said on the other side. Indeed, the very highest proof ever given of the large and generous spirit of Virginians was the burst of applause that everywhere greeted an accusation which, coming from a son less tried and proven by the fire of battle, might well have been accounted abuse and almost slander.

Virginians wanting in public spirit? 'Tis a new accusation indeed. Why, the cuckoo cry of the North for half a century has been that the Virginian devoted his time to politics, to the utter neglect of his private affairs. Well I know, and so does he, what manner of spirit it was that fired Virginia in 1860 , but 'tis not of 
that he speaks. Perhaps he means that, engrossed in self-admiration, our narrow sympathies would not permit us to love, I will not say the Yankees, but the American people. In my soul, I think the Virginian loved them better than they loved themselves; for he who truly loves liberty loves truly and to purpose all mankind. Is it public improvements that he means? Possibly, for public spirit and running in debt-hastening a premature and unstable civilization-seem to be synonymous nowadays. Well, then, I will take the forty millions, spent much against the old Virginia gentleman's will, in railroads and canals, that have brought the State to the verge of bankruptcy and repudiation, when a tithe of that sum expended, in maintenance of his faith, upon a well-devised system of county roads would have made ours the happiest and most solvent commonwealth in the South, if not in all the land. What call you that? Fealty to the first great principle of our American form of government-the minimum of State interference and assistance in order to attain the maximum of individual development and endeavorthat was the Virginian's conception of public spirit, and, if our system be right, it is the right conception.

Aye! but the Virginian made slavery the touchstone and the test in all things whatsoever, State or Federal. Truly he did, and why?

This button here upon my cuff is valueless, whether for use or for ornament, but you shall not tear it from me and spit in my face besides; no, not if it cost me my life. And if your time be passed in the attempt to so take it, then my time and my every thought shall be 
spent in preventing such outrage. Let alone, the Virginian would gladly have made an end of slavery, but, strange hap! malevolence and meddling bound it up with every interest that was dear to his heart-wife, home, honor-and by a sad providence it became the midmost boss, the very centre of that buckler of State rights which he held up against the worst of tyrantsa sectional majority.

But a darker accusation yet remains. This also is a discovery-made since the war. It is charged that our fathers threw away a great estate, an empire in truth, and surrendered constitutional rights of inestimable value, not for love of our common country, for peace and brotherhood, but for what, think you? Mark it well-for the sake of Federal office, and that alone! Yes! this is the accusation brought by Virginians against their fathers. No Yankee brings it. I never heard it till a Virginian of 1876 brought it. Though I may be excused for calling in question the motive of him who imputes such motives to others of his own flesh and blood, I will not do so. I will summon history to bar, and ask her whether the Virginians who espoused New England's cause and perished amid the snows of Canada were office-seeking when they died? And I will file in answer to this charge a single act of our Legislature in 1867, when Virginia, impoverished and dissevered, assumed the entire indebtedness, principal and interest, of two States. Was that officeseeking? Was that the prompting of self-interest?

Noble folly? Magnanimous stupidity? Nay, I reckon it rather the dying murmur, the last true beat 


\section{THE OLD VIRGINIA GENTLEMAN}

of that great Virginia heart, whose generous and unselfish pulse kept time to an exalted sense of duty.

This doubtless was the weakness of the Virginia gentleman of the olden time. It was not the weakness of a mean or grovelling spirit, or one in imitation of which the world will soon destroy itself. He was not wiser, he was not more learned, he was not more successful than other men. Wherein, then, lay his strength, and what was the secret of his influence over all this land? I answer in one word-character. And what is meant by character? Courage? Yes; the courage of his opinions, and physical courage as well, for he had a Briton's faith in pluck. Pride of race? In a limited sense, yes. Honesty? The question is almost an insult. "Madam," said Judge John Robertson, when in Congress, to his wife, who asked him to frank a letter for her, "Madam, I am not a thief!" Love of truth? Yes; undying love of it. And more--what more? A certain inherited something in the blood and bodily fibre that fused all these qualities and lifted them as steady concentrated light in a Pharos, so that the simple look of the man, the poise of his head, his very gait, betrayed the elevation of his nature. Therein lay his strength, before which wiser men, as the world runs, and far wealthier men bowed almost in homage. Character-character, fixed upon the immutable basis of honor, and a love of liberty unquenehable-that was the source of his power, and the whole of it.

From the pale, defeated lips of Virginians, weakened by poverty, comes the sneer (we hear it too often nowadays), "Can honor sct a leg?" No, truly; 
but dishonor can damn to everlasting infamy a human soul.

But whatever its source, character, or what you will, the greatness of the Virginian in times past cannot be gainsaid; it is everywhere conceded. And yet this mediocre age, which sneers at honor, naturally enough decries greatness. Decries? yea, denies its very existence. "The individual withers, and the world is more and more." So much the worse for the world, were it true. They who looked Lee and Jackson in the face, and fought under them; they who have seen Bismarck and King William make Germany in the very teeth of its hostile Reichstag, believe it. How passing strange! String ciphers till the crack of doom, they count nothing. Cut out of the world's book the pages made lustrous by the words and deeds of great men, and the rest is blank. Myriads living in Africa for unnumbered centuries have left no sign. But look at Greece; at only one of its States. Galton, in his able work on "Hereditary Genius," calls attention to the "magnificent breed of human animals" reared in a single century in Attica, enumerates fourteen of the greatest of them, and says, "We have no men to put by the side of Socrates and Phidias. The millions of all Europe, breeding for two thousand years, have never produced their equals. The population which produced these men amounted to 135,000 free males, born in the century named, 530-430 B. C."

On the first day of December, 1763, Patrick Henry made his speech in the Parsons' cause, and after the Convention of '29-'30 the giants no longer assembled in 
Virginia. I will put the breed of human animals reared in this interval, less than a century, out of a free male population not exceeding that of Attica, against any other ever produced in this world. I doubt if the Roman senate or the Athenian Areopagus ever at one time contained quite such a body of men as were gathered in our famous Convention, and I will say, with Galton, that we have not now, nor are we likely ever again to have, two such men as Washington and Jefferson.

But, would you believe it, Jefferson is a plagiarist! a thief not only of words, but of ideas! He has no claim to originality - his thoughts, his very language, everything borrowed or stolen outright! That has been deliberately and publicly charged, not by men of the North, but by a Virginian. Well, let us see.

"This new principle of so constituting a federal republic as to make it 'one nation as to foreign concerns, and to keep us distinct as to domestic ones,' was indicated as early as December, 1786, by Mr. Jefferson in a letter to Mr. Madison." That is an historical fact, testified to by Alex. H. Stephens.

"It is the very greatest refinement in social policy to which any state of circumstances has ever given rise, or to which any age has ever given birth." That is the testimony of Lord Brougham. "It is a wholly novel thing, which may be considered a great discovery in modern political science, and for which there is even yet no specific name." That is the testimony of De Tocqueville. This will suffice. Jefferson's fame is firm-based as the pyramids; it cannot be shaken; and they who decry hin do but belittle themselves. 


\section{THE OLD VIRGINIA GENTLEMAN}

A soil is known by its crops, a tree by its fruit. Materials are tested by the strain they will bear; flowers give forth their sweets under compression, but yield their inmost virtues only to the torture of the crucible. The flowers and the fruitage of a land are its men. The test of men is the strain of war; the supreme test the torture of defeat. Virginians were tested in the War of the Revolution, again in 1812, again in Mexico, again in the great rebellion, so called, and yet again in the long torture of reconstruction. Where, I ask in the candor of a triumph so amazing that it almost humiliates, where are all the honors? Were these successive honors the result of chance? Are the great names and the heroic deeds associated with these wars of no value? There can be but one answer, and it is so complete it saddens me; for well I know-I think I know-the end has come. It has certainly come if, for the sake of present comfort, the Virginians of to-day are willing to forfeit these honors and to despise these names. What neither war nor defeat could effect, poverty, long continued, has accomplished -it has broken them down at last. I fear so, indeed.

My friends, it is not I who say it; it is nature, it is God who says it-man, like all other organisms, is subject to his environment. Change the environment, he changes with it; destroy it, and he is destroyed. But 'tis not the earth he treads nor the air he breathes that constitutes man's true environment; it is the social atmosphere that makes the man or mars him. Great minds, great hearts, noble spirits, are not fed on base thoughts and low ambitions; and if the glory of Vir- 


\section{THE OLD VIRGINIA GENTLEMAN}

ginia in the past has been incontestably greater than that of all her sister States combined, it must be because her sons inhaled at home a finer, purer air. Ask yourselves whether that atmosphere has changed or is changing, and frankly own all of good or ill that slavery involves. If it accompanied here, as in Greece, the development of a splendid breed of animals, say so; if it helped that development, say so fearlessly. For one, I say with confidence, that the abolition of slavery has so changed the environment of the Virginian that another and wholly different man must take his place. Will he be a better man? I do not know; I hope he may. Will he be worse? Time will tell.

But whatever the Virginian may have been, the coldest envy and the meanest jealousy may look upon him now with complacency. If he were vain, his vanity stands him now in little stead. If he were proud, his pride need wound you no longer. "No farther seek his virtues to disclose, or draw his frailties from their dread abode;" but come-

\section{I}

Come listen to another song,

Should make your heart beat high,

Bring erimson to your forehead,

And lustre to your eye.

It is a tale of olden time,

Of days long since gone by, And of a baron stout and bold

As e'er wore sword on thigh,

Like a brave Virginia gentleman

All of the olden time. 
His castle was his country home

Hard by the river James,

Full two hundred servants dwelt around-

He called them by their names;

And life to them no hardship was,

'Twas all things else I ween;

They were the happiest peasantry

This world has ever seen,

Despite the Abolition chevaliers

All of the Northern clime!

III

His father drew his trusty sword

In Freedom's righteous cause, Among the gallant gentlemen

Who made nor stop nor pause

Till they had broken wide apart

The British bolts and bars,

And lifted up to Freedom's sky

The standard of the stars,

Like true rebellious gentlemen

All of that manly time.

IV

He never owned a foreign rule,

A master he would scorn;

Trained in the Revolution's school,

To Liberty was born!

And when they asked him for his oath,

He touched his war-worn blade,

And pointed to his lapel gray,

That bore the blue cockade!

Like a straight-out States' Rights gentleman,

All of that trying time. 


\section{THE OLD VIRGINIA GENTLEMAN}

$\mathrm{V}$

And then the words rang through the land,

"Coercion is to be!"

"Coercion of the free?"

That night the dreadful news was spread,

From mountains to the sea;

And our old Baron rose in might

Like a lion from his den,

And rode in haste across the hills

To join the fighting men,

Like a staunch Virginia gentleman, All of the olden time.

\section{VI}

He was the first to fire the gun

When Sumter was assailed, He it was who life disdained

When our Great Cause had failed,

And ever in the van of fight

The foremost still he trod,

Until on Appomattox' height

He gave his soul to God,

Like a good Virginia gentleman, All of the olden time.

\section{VII}

Ah! never shall we know again

A heart so stout and true;

The olden times have passed away,

And weary are the new.

The fair white rose has faded

From the garden where it grew,

And no fond tears save those of heaven

The glorious bed bedew

Of the last Virginia gentleman

All of the olden time! 


\section{THE OLD VIRGINIA GENTLEMAN}

Oh! good gray head of Arlington! when thy great sore heart, that ever took unto itself all blame, burst behind the mute lips, and Rockbridge earth received the stateliest man of all our time, then indeed the last Virginia gentleman was laid to sleep in his mother's lap, and the heroic age of Virginia ended. "The spacious times of great Elizabeth" come not again; there is no second age of Pericles.*

* Doubtless the picture here drawn of Virginia as she was is idealized. Purposely so. Not for a moment could any Virginian say that there was nothing amiss in the old order. Alas! there is much amiss in every strueture, old or new. Educated at the North, I was perhaps more keenly alive to the defects of our system than almost any Virginian of my time. And so long as the good Commonwealth lived I did not fail to mix in every panegyric I wrote-and there were several - a full proportion of goodnatured satire. If I have praised Virginia without stint, I have, in times past, ridieuled her unsparingly. But our Mother is dead, and much may be pardoned in a eulogy which would be inexcusable were the subject living. I ask no man's pardon for what must seem to a stranger a most exaggerated estimate of my State and its people. In simple truth and beyond question there was in our Virginia country life a beauty, a simplicity, a purity, an uprightness, a cordial and lavish hospitality, warmth and graee whieh shine in the lens of memory with a eharm that passes all language at my command. It is gone with the soeial structure that gave it birth, and were I great, I would embalm it in the amber of such prose and verse as has not been written since John Milton laid down his pen. Only greatness can fitly do it.-Author's note. 


\section{BACON AND GREENS}

T $\mathrm{T}$ is morning-clear, cold, sparkling-an autumn 1 morning. Come with me into the garden. The frost lies heavy on the palings, and tips with silver the tops of the butter-bean poles, where the sere and yellow pods are chattering in the chilly breeze. On yonder fence hangs many a gourd, once green, but scabby now and nearly ripe. Across the walk, in that broad bed, "severial" paunchy "punkins" lie, half-a wakened by the distant rooster's call. The lily and the rose, the tulip and the violet, the sunflower and the hollyhock are dead. Beautiful, but feeble, they have perished early; and the humming-birds and the bumblebees and the Juney-bugs, which knew them once, shall know them no more forever. One flower alone survives - a sturdy flower, that scorns Jack Frost-a remarkable flower, for it is at once a flower and a fruit, and it is all flower, and is its own bush and its own leaves. Let us reverently draw nigh unto it. Gods! what a bud! And see, alas! how its gigantic petals have been pecked by the turkeys! May we not venture to touch the mighty bud! Heavens! 'tis not a bud-'tis a head! Finer head Fowler the phrenologist never felt. How crisp and cool, how firm, and full 
as it were of brains this head is! And what a peculiar whitey-greenish color, and what a still more peculiar sort of culinary odor! Surely we have smelt it before. Yes; this is the cabbage, sacred to tailors and to the Virginia dinner-table.

Here the vegetable portion of our subject ends, and we approach that strange variety of mankind which is compounded of bacon on the one hand, and cabbage or greens on the other hand. In the wildest flight of imagination, who would ever have supposed that the savage boar of the German forests and the ugly potherb of the sea-cliffs of England would come together in the same dish to produce the Virginian? So true it is that truth is stranger than fiction. I say, the Virginian; for while other people eat bacon and greens (and thereby become very decent people indeed), the only perfect bacon and the only perfect greens are found in Virginia; and hence it follows, as the night the day, not that the Virginians are the only perfect people, but that they are a peculiar and a very remarkable people.

In point of fact, the native Virginian is different from all other folks whatsoever, and the difference between him and other folks is precisely the difference between his bacon and greens and other folks' bacon and greens. How great this difference is, you are by no means aware. There is a theory in the books that the superiority of the Westphalia and Virginia bacon over all other bacon is due to the fact that our hogs are not penned up, but are allowed the free range of the fields and forests. 
Nevertheless, you are not to infer that the Virginian is composed of equal parts of bacon and greens, and that he is, in point of fact, a saphead and a glutton. Such a conclusion would not only be unkind, but illogical. Drinking train-oil does not necessarily turn a man into an Eskimo, nor does the eating of curry compel one to become a coolie and worship Vishnu or Confucius. Still, there is a connection between diet and the ethnological characteristics of the human races; and I take it for granted, first, that a Virginian could not be a Virginian without bacon and greens; and, second, that in every Virginian traces of bacon and traces of greens are distinctly perceptible. How else are you to account for the Virginia love of good eating, the Virginia indifference to dress and household economy, and the incurable simplicity of the Virginia head? It has been affirmed by certain speculative philosophers that the Virginian persists in exhausting his soil with tobacco, because the cabbage he eats is itself an exhauster of the soil, and that, because the hog is fond of wallowing in mud-puddles, therefore the Virginian takes naturally to politics.

I am not prepared to dispute these points, but I am tolerably certain that a few other things besides bacon and greens are required to make a true Virginian. He must, of course, begin on pot-liquor, and keep it up until he sheds his milk-teeth. He must have fried chicken, stewed chicken, broiled chicken, and chicken pie; old hare, butter-beans, new potatoes, squirrel, cymlings, snaps, barbecued shoat, roas'n ears, buttermilk, hoe-cake, ash-cake, pancake, fritters, pot-pic. 
tomatoes, sweet-potatoes, June apples, waffles, sweet milk, parsnips, artichokes, carrots, cracklin bread, hominy, bonny-clabber, scrambled eggs, gooba-peas, fried apples, pop-corn, persimmon beer, apple-bread, milk and peaches, mutton stew, dewberries, battercakes, mushmelons, hickory nuts, partridges, honey in the honey-comb, snappin'-turtle eggs, damson tarts, catfish, cider, hot light-bread, and cornfield peas all the time; but he must not intermit his bacon and greens.

He must butt heads with little negroes, get the worst of it, and run crying to tell his ma about it. Wear white yarn socks with green toes and yarn gallowses. Get the cow-itch, and live on milk and brimstone for a time. Make frog-houses over his feet in the wet sand, and find woodpecker nests. Meddle with the negro men at hog-killing time, and be in everybody's way generally. Upset bcehives, bring big wasp-nests into the house, and get stung over the eye by a yellowjacket. Watch setting turkeys, and own a bench-leg fice and a speckled shoat. Wade in the branch, eat too many black-heart cherries, try to tame a catbird, call doodle-bugs out of their holes-and keep on eating bacon and greens.

He must make partridge-traps out of tobacco-sticks; set gums for "Mollie-cotton-tails," mash-traps and deadfalls for minks; fish for minnows with a pin-hook, and carry his worms in a cymling; tie Juney-bugs to strings, and sing 'em under people's noses; stump his toe and have it tied up in a rag; wear patched breeches, stick thorns in his heel, and split his thumb open slicing 
"hoss-cakes" with a dog-knife sharpened, contrary to orders, on the grindstone.

At eight years old he must know how to spell $b a$ ba, $b e$ be, and so on; and be abused for not learning his multiplication table, for riding the sorrel mare at a strain to the horse-pond, and for snoring regularly at family prayers. Still he must continue to eat bacon and greens. About this time of life, or a little later, he must get his first suit of store clothes, and be sorely afflicted with freckles, stone-bruises, hang-nails, mumps, and warts, which last he delights in trimming with a Barlow-knife, obtained by dint of hard swapping. He must now go to old-field school, and carry his snack in a tin bucket, with a little bottle of molasses, stopped with a corn-cob stopper, and learn how to play marbles for good, and to tell stories about getting late to school-because he fell in the branch. Also to steal June apples and bury them, that they may ripen the sooner for his big sweetheart, who sits next to him. He must have a pop-gun, made of elder, with plenty of tow to "chaw" for wads; also plenty of india-rubber, and cut up his father's gum shoes, to make trap-balls, composed of equal parts of yarn and india-rubber. At the same time he must keep steadily eating bacon and greens. He must now learn to cut jackets, play hard-ball, choose partners for cat and chermany, be kept in, fight every other day, and be turned out for painting his face with pokeberry juice and grinning at the school-master.

After a good whipping from his father, who threatens to apprentice him to a carpenter, he enjoys his holiday by breaking colts and shooting field-larks in the daytime 


\section{BACON AND GREENS}

and by possum-hunting or listening to ghost-stories from the negroes in the night.

Returning to school, he studies pretty well for a time; but the love of mischief is so strong within him that, for his life, he can't refrain from putting crooked pins on the benches where the little boys sit, and even in the school-master's chair. The result is a severe battle with the school-master and his permanent dismissal.

Thrown upon the world, he consoles himself with bacon and greens, makes love to a number of pretty girls, and pretends to play overseer. Failing at that, he tries to keep somebody's country store, but will close the doors whenever the weather is fine to "ketch chub" or play knucks.

Tired of store-keeping, he makes a trip, sometimes all the way on horseback, to the Far South, to look after his father's lands. Plays "poker" on the Mississippi, gets cheated, gets "strapped"; returns home, eats bacon and greens, and determines to be a better man. But the first thing he knows he is off on a frolic in Richmond, where he loses all his money at faro, borrows enough to carry him home and buy a suit to go courting in.

He next gets religion at a camp-meeting, and loses it at a barbecue or fish-fry. Then he thinks he will teach school, or ride deputy sheriff, or write in the clerk's office, and actually begins to study law; on the strength of which he becomes engaged to be married, and runs for the legislature. Gets beaten, gets drunk; reforms, all of a sudden; eats plenty of bacon and 
greens; marries-much to the satisfaction of his own, and greatly to the horror of his wife's family-and thus becomes a thorough-going Virginian.

His name, for the most part, is Jeems-Jeems Jimmison. Sometimes it is rather a homely name, as, for example, Larkin Peasley. Occasionally it is a pretty and even a romantic name, as for instance, Conrad, or, to speak properly, Coonrod-Coonrod Higginbottom.

Being a married man, it is incumbent on Coonrod to settle down in life; and to this end he selects, with unerring accuracy, a piece of the poorest "hennest" grass-land in his native county. The traveller enters this domain through a rickety "big-gate," partly upheld by mighty posts, which remind him of the druidical remains at Stonehenge. The road leads apparently nowhere, through thickets of old-field pine and scrub-oak. Here and there is an opening in the woods, with a lonely, crank-sided tobacco-house in the midst, looking as if it were waiting resignedly for the end of the world to come. He hears the crows cawing, the woodpeckers tapping, and the log-cocks drumming, but sees no human being. Far away the roosters are crowing, and perhaps the scream of the peacock is heard. Slowly sailing, white-billed buzzards eye him from on high and make him nervous. Over the trees, he can't tell where exactly, come the voices of the ploughers-“Gee," "Wo-haw," “Git up." He rides in the direction of the sound, but finds nobody. Anon he encounters an ox-cart, which turns aside for him. "Wo, Lamb!" "Come here, Darlin'!” “Back, Buck!" 
"Back! I tell you." The driver touches his hat and says, "Sarvunt, marster," but is too busy with his steers to give any directions. And, when his patience is fairly exhausted by a succession of dilapidated gates, tied up with grapevines, and complicated drawbars, which compel him to get down from his horse and fill his hands with turpentine (for Larkin's negroes won't half skin the poles which make the drawbars)when the traveller is thus bewildered and exhausted, and half tempted to turn back, he is suddenly relieved by an ebony apparition, resembling somewhat a kangaroo, clad in a solitary, mud-colored cotton garment, split up to the arm-pit on one side, and dexterously kept in position by a peculiar upward twist of the shoulder on the other side. This black-legged little spectre pops out of a gully, where he has been quietly eating dirt, darts over the broom-straw, knocks down the mullein stalks, crashes through the sassafras clump, "skeets" through the brier patch, shoots around the plum bushes and up the lane, under the morillo cherry-trees, disappears behind the fodder and straw stacks, winds in between the stable, corn-houses, henhouses, the dairy, the smoke-house, and the kitchen; and so, like a veritable Jack-o'-lantern, with a nappy head, that resembles a diseased chestnut burr or part of the top of an old hair trunk, leads you up to the house itself.

There the native Virginian, with a Powhatan pipe in his mouth and a silver spectacle-case in his hand, awaits you, and asks you to "light" and "come in" in the same breath. While a negro boy is running 
up from the "new ground" to take your horse, a mulatto girl is flying, with a pail on her head, to the spring for fresh water and a jug of milk. Two or three little negroes are chasing the chickens whose necks are soon to be twisted or chopped off with an axe at the wood-pile; ham is being sliced, eggs are frying in the frying-pan, a hoe-cake is on the fire, another head of cabbage is thrown into the pot, somebody is sheeting the bed upstairs, and (before your leggings are off) the case-bottle is at your elbow, and the native Virginian has taken possession of you, as if you were the Prodigal Son or the last number of the Richmond Enquirer.

Meantime your arrival has produced an excitement among the small Ebo-shins, as you will discover the first time you step out into the yard. A number of wild, black eyes are intently watching you through the panels of the fence, and the conversation which ensues on your appearance shows the estimation in which "Ole Marster," as the native Virginian is called, is held by his young barbarians.

"I lay you what you dar," says one, "dat dat ar man come all de way from way down yarnder, clean to Rich'um."

"I lay," says another, "dat he war two par of gallowses-don' you saw de strops on his britchis?" "I spec," says a third, "dat ar man mighty rich. I spec he got bofe pockits full o' fopunsapunnies, and he gwine gin me two un 'um."

"Shuh!" replied a sage little gizzard-foot; "sluuh! y'all ain't talkin' 'bout nuthin' 'tall. Ole Narster he 
de richest man in de worl'. Ole Mars' kin buy a hom'ny mortar full o' dat ar man 'thout nuvver payin' fur 'um, an' den forgit it, 'fore dat ar man know it!'

We will not stop to describe his old weather-boarded often wainscoted, house, with its queer old furniture and its old family portraits, which indicate for Jeems Jimmison or his wife a better origin than his name would lead you to expect. One peculiarity, though, must not go unmentioned. No matter how small this house is, it is never full. There is always room for one more in it; and, on special occasions, such as a wedding or a Christmas frolic, the number of feather beds, straw beds, shuck beds, pallets, and shakedowns which this old house produces is literally incredible. 'To feed and lodge, if need be, the entire State is not a point of honor with Coonrod, but a matter of courseno other idea ever entered his head. What is called "hospitality" by other folks is with him so much a part of his nature that he has no name for it (unless he keeps an "Entertainment"), and he never uses the word. How he managed, on a worn-out estate, to repeat, as it were, the miracle of the loaves and fishes is a mystery which must be charged, I fear, to the "barbarism of slavery," for the art of feeding and lodging everybody scems already to be passing away.

Nor can we stop to describe the good wife of the native Virginian, with her check apron, key-basket, and knitting sheath-the pattern of domestic virtue; a matron, compared with whom the Roman matron, so famed, is as inferior as paganism is to the religion of our Saviour; the hardest-worked slave on the estate 


\section{BACON AND GREENS}

-toiling, as she does, from year to year and year after year, for every human being, black and white, male and female, young and old, on the plantation, and yet a Christian gentlewoman, refined, tender, purealmost too good and pure for earth. Think what she has done for Virginia! Think, too, that, under the new order of things, she also may be passing away. Of all the sad things which press upon us in these troubled days, there is none so sad as this; no, not one. For without the Virginia matron there is no longer any Virginia; and without Virginia, what, to Virginians, is this world? Let us hasten away from the thought.

In like manner, we must hasten away from Larkin's sons and daughters; the former brave and wilddestined to run much their father's course; the latter unaccountably pretty, spirited, and cultivated. If it be a matter of wonder how Mrs. Coonrod manages to get up such marvellous breakfasts and dinners out of her dingy, dirt-floored kitchen, still more wonderful are the girls whom she raises in her "shakledy" old house, ten miles from anywhere, and entirely out of the world. We cannot spare the time to praise the boys and girls-the noble products of a social system which mankind has united to put down-for the native Virginian, as we now find him, is almost entirely alone, his family being scattered far and wideall married and thriving, except one "black sheep," who has taken to drink, to fiddling, and to shrouding everybody in the neighborhood who dies.

In person, the old man is above the medium height, "dark-complected," spare built and generally long 
and lean in the lower limbs,-and that's the reason he rides a horse so well. His voice is loud, owing to a habit he has of conversing familiarly with the hands in the field about a mile and a half off. His vision is wonderfully acute-partly from long practice with the ritle, and partly from the custom of inspecting his neighbors' vehicles at incredible distances. If he live on the side of the road, you will see him on Sunday eying a cloud of dust on the remote horizon. "Jeems," he will say to his son; "Jeems, ain't that old Peter Foster's carryall?" "Yes,” says Jeems, without a moment's hesitation; " and I'll be dad-shim'd if that off mule has been shod yit." His accent is as broad as the nose of his blackest negro. He says "thar" and "whar," "upstars" and "down in the parster," talks about "keepin' a appintment," not next year, but "another year," when he expects to raise "a fine chance uv curcumbers" in the "gearden," and a “tollibly far crap o' tubbarker." If he is a tidewater man, he does not say "chance," but "charnce," and, instead of saying the "har" of the head, he says "heyar." If he eats cornfield peas much, he becomes a virulent Virginian, and caps the climax of bad English by some such expression as "me and him was a-gwine a-fishin'." This he does, not for the lack of knowledge, but partly because he loves to talk as unlike a Yankee as possible, partly because he "don' keer" particularly about his language or anything else, except his political and religious opinions, and mainly because he is entirely satisfied (as, indeed, all Virginians are) that the English is spoken in its purity nowhere on this earth but in 
Virginia. "Tharfo" " he "kin affode" to talk "jest" as he "blame chooses."

His individuality, his independenee and indiference to matters on which other people set great store, i. shown, not only in his pronuneiation, but in his dress - you see it in the tie of his cravat, the cut of hi crat, the fit of his waisteoat, the set of his pantaloons. the roaching of his hair, and the color of his pocket hancikerehief-a red bandanna with yellow spots. But the whole character of the man is fully told only when you come to open his "secretary." There you will find his bonds, accounts, receipts, and even his will, jabbed into pigeon-holes or lying about loose in the midst of a museum of powder-horns, shot-gourds, turkey-yelpers, flints, screws, pop-corn, old horseshoes and watermelon seed.

How such a man, with such a "secretary," can suceeed in life, and how, above all, he and the like of him contrived to play the part which they have played in the history of this country, is something to be accounted for only on the bacon-and-greens principle.

Since the first settlement at Jamestown, when the hogs increased so fast that the town had to be palisaded in order to keep them out, Virginians have been well spoken of; but of late, and since the downfall of the old Commonwealth, praise, in some quarters, had been lavish. Is it on the principle, De mortuis nil nisibonum, and because it is thought that Virginians are soon to be numbered among the races which have perished? I trust not. But hear what has been said of them by a Northern orator-the Hon. Ifenry Clay Dean, of Iowa: 
"I dare speak one kind word for the oppressed in the very teeth of the oppressor. Since Adam took possession of Eden, no part of his heritage has given to man such an hundred years of history as that of Virginia, beginning with the public life of George Washington, and ending with the surrender of the armies of Gen. Robert E. Lee. The great orator, Patrick Henry, whose spirit lifted up the first revolution, and whose persuasive voice called armies up the valleys and down from the mountains to defend New York, New Jersey, and Massachusetts from the invader's hoof, was a Virginian. George Washington, who led those armies, was a Virginian. Thomas Jefferson, whose great soul encompassed the world and lifted its light upon a benighted age to teach it liberty, was a Virginian. James Madison, who environed our rights by a flame of living fire, which, in the most illustrious periods of the past and present century, preserved unharmed all that was sacred in life and precious in hope-the Constitution of the United States,-was a Virginian. John Marshall, whose luminous mind, guided by immutable justice, gave being to a most profound and comprehensive judiciary, the bulwark of American institutions, was a Virginian. Henry Clay, whose commanding soul drew after him one full half of the whole moral and intellectual power of America, was a Virginian. The Lees-Richard Henry, Arthur Francis Lightfoot, Light-Horse Harry, and his illustrious son, Robert Edmund Lee, were Virginians. Thomas J. Jackson, the great military genius of the western hemisphere, was a Virginian. The courts 
and the legislatures, the forums, and the pulpits of every State in the Union, and of every government on the continent, have been adorned by Virginians. Their blood, shed in noble defence of liberty, has fattened every valley, and their bones have bleached on every mountain, from Bunker Hill to the City of Mexico."

I can imagine Larkin's smile as he reads, or hears read, these compliments. $\mathrm{He}$ is simple-minded and easily flattered; but-the sop comes a little too late. We, who know him better, have no flattery to bestow on him; on the contrary, if the truth must be told. we can but pronounce him as great a bundle of infirmities, crotchets, and vices as was ever put together. I say "vices." Does he not chew homespun tobacco inordinately and spit promiscuously? Does he not neglect to keep a set of books, and care more about giving good dinners than saving money? Was he not, in former times, in the habit of whipping his negroes as often, almost, as his own children? Did he not cherish the vile political heresy of State-rights, and, in his childish ignorance, proclaim the absurd proposition that Virginia, free and sovereign, antedated the Constitution, and, with her sister sovereigns, gave that Constitution all the power it possessed? Was he not a heretic in religion as well as in politics, and ever ready to maintain that the pulpit is no place for "Lessons of the Hour," and for the worship of national ensigns? Finally, instead of preaching, did he not practise the doctrine, "Do unto others as you would be done by," and hold that it was ungentlemanly to cheat, and 


\section{BACON AND GREENS}

wrong even to tell lies and to steal? For the life of me, I do not see how you are to flatter such a man.

As for the crotchets of the native Virginian, they are no great matter. He will have his pets-his blooded mare, his favorite pointer, his pack of hounds, his game rooster, "Dominicker" hen, "cropper-crown" pullet, muscovy drake, and a little lame negro, who lights his pipe with a coal of fire from the kitchen and pats "Juba" for him. But the most curious of his whims (and one which is somewhat rare among native Virginians) is a deadly hatred of liquor in all of its forms; an exceedingly strange whim indeed, you will admit, and one which, as I have observed, is generally accompanied by preposterous vagaries about the virtues of blood-root, puccoon-root, “jimson” wced, white-oak bark, dog-wood, wild-cherry, Indian-turnip, and wakerobin.

Notions like these may be tolerated, but who can bear the cabbage-head weakness of a man who will not consult his own interests before all other interests; will concern himself about politics when he ought to be inventing a new method of making doughnuts out of free-love, and looking, philanthropically, after the moral and intellectual welfare of the man in the moon; and who is so incurably conservative that he won't fill up the mud-puddle in front of his gate, won't mend the lock on his back door, or whitewash his worm-fences, or paint his crank-sided carriage-house, or clean the teeth of his cattle with Sozodont, or dress his field-hands in duplex-elliptic hoop-skirts? What are we to think of such a man? 


\section{BACON AND GREENS}

"A blunder," says Fouchet, "is worse than a crime," and, in a worldly point of view, the native Virginian is a mass of blunders. "A persistent course of murder," according to De Quincey, "will inevitably end in procrastination"-the worst of crimes; and procrastination is the grand characteristic of the native Virginian. He will not do to-day what can be done to-morrow, or do to-morrow what can be put off till the next day; no, not though the whole world of prompt business men get ahead of him-not though the heavens fall and the lightnings descend and put out the other eye of his one-eyed calf.

How such a man, so faulty, so simple-minded, so warm-hearted, so open-handed, and so what the world calls "lazy," succeeded in playing the part which he has played in history and exerted so powerful an influence in the government of this country, is, I repeat, a marvel which can be explained only on the bacon-and-greens hypothesis which I have broached. Look at the firm, tawny skin of his face, and if you are not reminded of pork about four days old, then your eyes must be even weaker than my own. Heaven defend me from irreverence, but I confess I never look at the august portrait of the father of his country without thinking of jowl and turnip "sallet." And that our fathers loved bacon and greens is proved by the fact that Chief-Justice Marshall, dining one day with Nicholas Biddle, had his plate changed five times, and each time insisted on being helped to bacon and greens. In the nature of things, it must be a fact that Stonewall Jackson was raised on the best family-cured 
hams. How else could he have trotted his "footcavalry" so rapidly up and down the Valley? I know that Joe Johnston loved good bacon, because he was born in Prince Edward, not very far from Farmville. Jubal Early, judging from his manly letters while in exile, must have been raised entirely on chine-backbone.

As for Robert E. Lee, there is a story in De Fontaine's "Marginalia" to the effect that, during the latter part of the war, General Lee lived exclusively on cabbage boiled in salt-water, and allowed himself the luxury of middling only twice a week. One day, while in eamp, he invited a number of distinguished guests to dine with him. When the table was set, behold a great pile of cabbage and a piece of middling about as big as the palm of your hand. Out of politeness, the guests all declined middling. Next day the general called for it. "Marse Robert," said his servant; "Marse Robert, de fac' is, dat ar was borrid middlin', an' I done 'turn'd it to de man whar I borrid it fum." General Lee heaved a deep sigh of disappointment, and pitched into his cabbage.

That's the story, and a great many people don't believe it. I do; every word of it; especially the part about the cabbage. But I will tell you a story about General Lee worth two of that, and one which is true; for I got it from an officer who heard General Lee tell it on the very day of its occurrence.

"Not long after the surrender, a soldier, ragged, haggard, and dirty, rang at General Lee's door and called for the general. He was shown into the parlor, 
and, in a few moments, General Lee came in. 'General,' said he, standing up as General Lee entered, 'I'm one of your soldiers, just from Point Lookout.' The general shook him cordially by the hand. 'And I've come here,' he went on, 'as the representative of four of my comrades, who are too ragged and dirty to venture to see you. We are all Virginians, General, from Roanoke County, and they sent me here to see you on a little business.' He paused a moment, and continued. 'They've got our President in prison' (here the large tear-drops rolled slowly down his hollow cheeks), 'and -now-they-talk about ar-resting-you.' His voice here fairly broke into a sob. 'And, General, we can't stand, we'll never stand, and see that.' His sunken chest heaved convulsively; but, choking down his sobs, and with his eyes still wet, he continued his little address. 'Now, General, we five men have got about two hundred and fifty acres of land in Roanoke-very good land, too, it is, sir,-and, if you'll only come up there and live, I've come to offer you our land, all of it, and we five men will work as your field-hands, and you'll have very little trouble in managing it with us to help you.' Still speaking through his tears, he kept on. 'And, General, there are near about a hundred of us left in old Roanoke, and they could never take you there, for we could hide you in the hollows of the mountains, and the last man of us would die in your defence.'

"General Lee was affected to tears by the greathearted generosity and devotion of this noble soldier and his companions, but was compelled to decline his offer. 
"Still, the Roanoke hero would not give it up. With a great deal of delicacy, he intimated that the ladies of General Lee's family would lack society on a lonely mountain farm, but said that the Springs were hard-by, and that, out of the proceeds of the farm, General Lee and his family could afford to spend all their summers there, and thus find the society which those devoted 'field-hands' did not dare to offer.

"But General Lee was still forced to decline. Nevertheless, he would not allow the brave fellow to depart until he was better clad than when he came in. Scanty as was our great chieftain's wardrobe at that time, he insisted on sharing it with the Roanoke soldier."

We must return to our subject. The theme, to me, is inexhaustible; not so is your patience. You see I have spoken of the native Virginian in the present tense, not in the past. Thank God! I can do so; for the native Virginian "still lives." An impression prevails that this great original will soon be numbered with the brave men who were before Agamemnon, and that he is passing into history quite unconsciously to himself. I can see the old man as he sits by his deserted hearth, where the fire, made of his fence-rails (for there is no one to cut wood for him), is dying out. The coffee-pot, brought by the one faithful servant, sets on the "trivet" as of yore; but the purring cat, the little negro girls picking cotton, the clicking needles of the comely matron, and the wide circle of cheerful sons and daughters, nephews and nieces, with the welcome stranger, are gone. Gone are the heaped-up logs of 
hickory and the roaring flames, which once widened that family circle till the chairs of the whispering lovers touched the chamber walls; even the coals under the "trivet" are dead, the coffee untasted, and the single cake of corn-bread on the table is forgotten.

Poor old man! The night is bitter cold, but he sits by the dying fire, with his head bowed in his withered hands, unconscious of the cold. The tall old elock has ceased to tick; what recks he of the time? The negro-quarters are empty, the old cook is asleep in the kitchen-there is not a living soul in the house but himself. Without, the icy rain is pelting pitilessly, and the winter winds are sobbing as if in agony. The empty house shakes under the tread of the tempest, and there are ghostly noises in the lifeless, chilly rooms. Poor old man! his good wife has not survived the shock of war; his daughters, with their children, have fled for safety to the towns; and of all his bold sons, not one is left-they are under the sod at Manassas, at Gettysburg, at Chickamauga.

Poor old man! Once only he lifts his gray head - to look through the window-panes, blurred by the tears of the wintry rain. Over his frozen fields, where no crops are seeded for the coming year, over the dead waste of his neighbors' fields, over forest and mountain, over State after State, the vision of his thought extends; and in all that space, wide as a continent, he sees naught but broken and deserted households like his own, plantations devastated, industry destroyed, masters impoverished, and servants doomed to extinction-a benign civilization overthrown by one rude earthauake 
shock, blasted and obliterated, as if lightning itself had scorched and scathed the land.

What a picture for his dim eyes, weary of the world, to dwell upon! What hope for him, who looks out upon this wide-extended scene of sorrow-thrice sorrowful because of the winter storm, thrice sorrowful still because of the contrast with the plenteous, joyous days that are forever gone-what hope for him but in the grave? Better, far better, that he should be gathered unto his fathers ere yet the more evil days have come. Poor old man!

Poor old man! Who says this? Who desires to harrow up your feelings and to kindle new animosities? My friends, the middle-age chronicles tell us, in regard to the wild boar, that "what place soever he biteth, whether on man or dog, the heat of his teeth causeth an inflammation of the wound. If, therefore, he doth but touch the hair of the dog, he burneth it off; nay, huntsmen have tried the heat of his teeth by laying hairs on them as soon as he was dead, and they have shrivelled up as if touched with a red-hot iron."

Of this hot and touchy nature is the native Virginian.

Further it is said of the boar: "He hath a knack, when stabbed, of running up the shaft of the spear, so as to gore his slayer even in his own death-pang." Am I treading upon dangerous ground? Be not disturbed. The Virginian is not going to run up the shaft of the spear; he is not going to gore his slayer, for he is not going to be slain. Not less brave than other men, he nevertheless objects to dying while there 


\section{BACON AND GREENS}

is anything left to live for; and there is something to live for. It is that "fair and abounding land" which gave him and his children birth, and which is now doubly dear because of the infinitely precious blood which has moistened and hallowed it forever.

Moreover, the Virginian is the last man on earth to accept commiseration. Flatter and fool him, you may easily; but pity him, never! He will none of it. Pascal tells us that "pity for the unfortunate is no proof of virtue; on the contrary, it is desirable to make this demonstration of humanity, and to acquire, at no expense, the reputation of tenderness. Pity therefore, is of little worth."

The Virginian, possibly, never heard of Pascal; but he feels this in his heart, and he scorns your pity. Lord Halifax says, "Complaining is contempt upon one's self," and therefore the Virginian does not complain. He accepts the issue of the great struggle, not as the will of man, but as the will of Him whom he was taught to reverence and obey at his mother's knee. He was brought up to tell the truth, and to keep his word. Now that the hatchet is buried, the Virginian will keep the troth he has plighted to the General Government. Rest assured of that.

Remember, moreover, that no kind of live stock is so easily improved as the hog on which the Virginian subsists, none so readily accommodate themselves to circumstances, and that the changes produced by domestication and civilization are permanent. Remember, too, that few plants are so hardy as the cabbage, and none so vastly improved by transplanting. (This 


\section{BACON AND GREENS}

is the secret of the Virginian's success outside of his own State.) What is the inevitable influence? It is this: The Virginian will adapt himself to the new order of things; he will master the situation; and, under the stimulus of Progress, with a big $\mathrm{P}$, the size of his head (cabbage-head though it may be deemed by his foes) will astonish the moral agriculturists of all Christendom - the Captain Wragges of Exeter and Faneuil halls.

He loves the land which God gave him as a heritage -loves it and is proud of it a thousand-fold more than ever. But he will not oppose Progress. If anybody wants his land, he will sell 'em a "tract"; but he will retain enough to raise his greens and give his hogs free range, so as to keep up the quality of his bacon. He will welcome immigrants by myriads and without fear, because he knows he can feed them on proper food and turn them into Virginians with surprising rapidity.

In his changed estate-his servants all gone-he will no longer be able to board and lodge the whole world; but he will be able to give his friends a hearty, old-fashioned Virginia welcome, and a dish of real old Virginia "Bacon and Greens." 


\section{MY UNCLE FLATBACK'S PLANTATION}

\section{A RAMBLING SUMMER PIECE}

WHEN you get to the little town of $\mathrm{F}-$, look out of the car window, $O$ passenger on the $S$ side railroad! and you will see an old gentleman, with a long knotty staff in his hand, a broad-brimmed white wool hat on his head, a heavy iron-gray beard on his chin, a small long-tail black coat, out at elbows, on his back, and tow-linen pantaloons on his nether extremities-a striking object in the large motley crowd which swarms around the depot every time the train arrives. This is my Uncle Flatback, come to town to get the mail and take notes of every man who enters the bar-room, in the basement of that commodious tavern you see across the way. A remarkable man is old Flatback-“Uncle Jeems," or, in that negro dialect which Virginians so delight in, "Unc' Jim"-as he is generally called, for short. Do you wish to know more of him? You will get out of the cars, follow the railroad track through the Deep Cut, over the Buffalo Bridge, and along the great embankment, until you come to a persimmon-tree on the right-hand side of the road. Looking to the south, you catch a glimpse 
of a house embosomed in trees, with stables and other out-houses close by. That is the Flatback mansion, dubbed Mountain View, from the circumstances that the blue knob of a mountain, in an adjacent county, is visible from the premises.

I am sure you will like Uncle Flatback's house and yard-the former is so cool and roomy, the latter so level, green, and shady. Indeed, there are two houses, an old and a new one, joined by a covered passage, with folding doors, which when thrown wide open, in the summer time, turn the passage into a porch-the most delightful part of the house; for the breeze is always blowing there. The old house is charming, I think. It is only a story and a half high, and is built in that solid, honest way which was the rule everywhere in Virginia before the new-fangled, flimsy, slazy style of the Yankees was introduced. The chimneys are in one corner of the rooms, and being big, old-fashioned, triangular fellows-enough bricks in one of them to make a modern house-one chimney answers for half a dozen rooms, if need be; consequently the rooms are five-sided instead of square - which pleases me mightily, because it is Virginian, and smacks of the old days. If ever I build a house, I shall pattern after the old Virginia style. Hang your model cottages-your suburban villas-your Hudson River contraptions; I'd as soon eat codfish chowder and cold bread, or subscribe to a Yankee newspaper, as live in one of them.

There are four rooms below, including the diningroom, and two above stairs, in the old house. Uncle 
Flatback inhabits the room next to the little back porch, which looks toward the kitchen, the negro quarters, the corn-house, and the stable. His door is never locked from one year's end to another. It is true, there are two double-barrel guns and a rifle in the corner by the wardrobe, but they are never loaded, except when a crow or a hawk comes near the house, and as the old load has always to be drawn-lightning would hardly explode it-before the new one is put in, you may judge in what danger thieves, feathered or unfeathered, stand at Mountain View. 'The back porch, facing east, receives the first rays of the morning sun, and is shady nearly all day; hence it is a favorite resort of mine, though I am generally in the way, for there is always some household business going on here -some slicing of curcumbers (call 'em kewcumbers? Never!), shelling of peas, washing of butter, or rinsing (I'd rather say rensing, yea, even renching, if you will allow me) of things. But I love to see people slice curcumbers and shell peas. Then it is so pleasant to be where you can see dinner coming in-where the dishes are stopped on the way and fixed up-more butter put in the beets, a little more pepper in the stew, and so on.

I have a passion for porches. 'To me, a porch is

A thing of beauty-a joy forever,

except in very cold weather. If I had the building of a house, I would make it mostly of porches, upper and lower, with a room or so hung here and there on a nail driven into the pillars. IHad I been unfortunate 
enough to have lived in the days of the ancients, I would have kept a stoa - not that I have any mercantile talent-and talked philosophy and "High Dic" against the best of them, with my heels on the "bannisters" and a pipe in my mouth. If Socrates had come fooling after me, trying to trap me, I would have told him I was a hardshell Baptist, given him a chew of tobacco, and requested him to behave himself. But I wouldn't give a white-bone button to have lived in the days when the domestic negro and fried chicken, with plenty of creamy gravy and a few sprigs of fresh parsley were unknown. The Greek is a fine language, but I prefer Virginian. It has no aorist, no middle voice, and other woes to the early getter-by-heart. A Virginian can say what he has got to say without regard to grammarthat vile infraction of the Bill of Rights and the liberties of the people. I contend that freedom of speech is possible only in Virginia.

Then again, I couldn't have gone the ancient costume. It is picturesque, does well for marble, and for historical paintings in oil, but it is sadly unfit for a citizen of Buckingham or Prince Edward. Imagine a man walking through a new ground, or a ploughed field, with a great sheet flapping at his calves. He would feel worse than a woman. Consider him in a brier patch. How could a body get over a fence, ride a horse, or chase a hare, say nothing of climbing for coons? In the saddle, my breeches have a grievous tendency upward anyway, as if the washerwoman had starched them with leaven; what on earth would become of me in a toga? I would show ankles higher than a circus 


\section{MY UNCLE FLATBACK'S PLANTATION}

rider, or a White Sulphur belle dancing the German; I couldn't bear to go to town unless the people would do as they did when Queen Godiva rode through the streets of Coventry. No, you painters keep your grand historical wardrobes; give me a straw hat, an oznaburg shirt, no waistcoat, tow-linen pantaloons, with yarn "gallowses," home-made cotton socks and a pair of low-quarter shoes, moderately thick-soled, made by Booker Jackson.

The attic rooms, up the "little stars," in the old house are delightful to sleep in when the summer rains are drumming lullabies with their soft wet knuckles on the mossy shingles, or in winter when the icy gusts suck up the flames from the deep little fireplace. I know not why it is that attics, with their sloping ceilings and little windows on cither side of the chimney,

Where the sun comes peeping in at morn,

have such attraction for me. Don't let's analyze feelings; vivisections are so horrid, and the weather, to-day, is so warm. Who can trace the origin of ideas and emotions, when the thermometer is $90^{\circ}$ in the shade? Who can be a metaphysician with a fly in the burr of his ear, and two on his forehead? Iocke himself couldn't. Dear reader, you know what a country-not a hotel-attic is. The very name brings back the days of childhood, with a thousand gentle memories, which we may hint but never tell. And if you have ever been so happy as to lodge in an attic tenanted by a young lady, who makes way for you because the house is small, or the guests are many, then 


\section{MY UNCLE FLATBACK'S PLANTATION}

memories brighter than any of childhood are yours forever, and thenceforth attics are sacred in your eyes. My good fortune, not very many weeks ago, led me to a little upper chamber in a house on ground which has since become historical. The dormer-windows of that little chamber looked out upon the Chickahominy.

A feeling of awe comes over the sinner as he ventures tremblingly into the sanctuary where Sleep, the good old nun, keeps watch over the maiden Virtue. He puts the candle upon the spotless dressing-table and stands irresolute. All is so still-so tidy and orderly; so clean and fair; so sweet and pure. Angels are here. He sees their robes in the curtains of the windows, the drapery of the chaste couch and the dressing-table. What shall he do? How dare he get in that bed? The pictures on the wall are looking at him; the mirror is a great big glaring eye. What! disrobe here? Not he. He catches sight of his pale, distressed face in the looking-glass, and laughs a low laugh at himself. Uneasy, delighted wretch. He wouldn't be out of here for the world, but he don't know what to do. He is afraid to move, lest he disarrange or knock down something. Finally, after much cogitation and perplexment, he thinks it will be no harm to sit down in that little chair in the corner, and steps softly toward it, bumping his head as he goes along. "Dear me! what low chairs ladies do use!" A view of the whole room-half in shadow, half in shine-pleases him much. He contrasts it with his own disorderly bachelor's den, and sighs. One by one he takes in each separate object, marks them all with a note of admira- 


\section{MY UNCLE FLATBACK'S PLANTATION}

tion, and at length fixes his eyes permanently on not the smallest article of furniture in the room. Long time he broods over it, his blameless thought

Cozening the pillow of a lawful kiss.

He thinks of the nest of some white-winged dovethe shell of the pearl of purest ray serene. "Bless her sweet soul!" ends his reverie, and up he rises, for it is getting late, and he must decide upon the course he shall pursue till morning. Grown bolder, he presumes to touch the little bottles of Bohemian glass on the toilet-table, and marvels much at everything-deeming womankind wonderful creatures in all their ways, and envying the hardihood of those courageous men whose brazen and impudent nerves carry them unfalteringly through all the "masked batteries" and feminine mysteries which surround and terrify him here at dead of night. He takes up tenderly, as if they were so many infants, the books that lie on the dormer-window-sill, reads their titles, approves the literary taste of the young lady, and lays them carefully down again, exactly as they were before he put his profane hands upon them, listening the while, and hoping nobody downstairs hears him fumbling about; for now it is very late indeed. The candle is in the socket-he must do something. What! Ah! now he has it. He will play henchman to his lady love, lie down outside the door, and guard her chamber, as though she herself were sleeping there. But the servant, unacquainted with romance, coming in the morning to bring fresh water 


\section{MY UNCLE FLATBACK'S PLANTATION}

and black his shoes, and finding him stretched in the passage with his clothes on, will declare he is drunk. At last, his candle being out, he remembers that he was sent here to go to sleep in the accustomed mode, and praying to be forgiven, he reclines upon the outermost edge of the dove's nest, yields him to sweet fancies, which presently become dreams, and so-good night to him, for 'tis the happiest of his life.

We return to the "little stars" which lead to the attic in the old house at Mountain View, in order that we may notice the workmanship. Here is admirable carpentry-joining such as you rarely see in these degenerate days, and material unknown to our impatient green-timber times. How firm the steps are underfoot and how unworn, although they have been in daily use full half a century! It is true the light-slippered feet of the ladies and the bare soles of Ethiopian and mulatto maids have frequented this sturdy little staircase, but the very grain of the wood, polished to the neck-breaking point, shows what honest workmen our fathers were.

I would like for you to rest a moment in the room at the foot of the attic staircase, because I have something to tell you. There is nothing in this room to attract attention, except a red-cushioned settee and one of those old-fashioned combinations of bookcase, desk, and bureall, which are becoming so rare. When I first set up in life-atat 21, as M.D.-I owned one of these old conveniences, but sold it in less than a year, like a fool. How I could have managed to lug the thing about with me in my manifold wanderings, sub- 


\section{MY UNCLE FLATBACK'S PLANTATION}

sequent to the Esculapian era, it is impossible to say; but if ever I do get settled in a country home I intend to have a "secretary" - what a fine old name!-at the risk of my life. How in the name of sense is a country gentleman to get along without a secretary, with its endless pigeon-holes and secret drawers to keep his shot-gourds, powder-horns, cap-boxes, bonds, accounts, and odds and ends of everything in, I should like to know? Why it wouldn't be worth a man's while to have a son without a "secretary" to unlock for him on rainy days, as a special and very great favor: nor would there be any place to hide things from a man's wife. It is folly to expect a boy to entertain proper respect for a father who doesn't own a "secretary" that wonderful household museum and arcanum of manhood's great mysteries and treasures.

But about the little room at the foot of the staircase. Listen.

One summer night, years ago, long before my Uncle Flatback ever dreamed of living here, a young lady tripped noiselessly down these old stair steps, then almost new, and jumped out of the window. The wheat, heavy with dew, was growing up to the very walls of the house, and lest the young lady's clothes might get wet, an obliging young gentleman is at hand, to receive her in his arms and carry her through the wheat-field. In the edge of the woods, some hundred yards off, a handsome vehicle, drawn by blooded horses, is waiting. Round go the wheels-off fly the young couple through the forest, and ere the morrow's sun is set, they are in North Carolina, married. Very 


\section{MY UNCLE FLATBACK'S PLANTATION}

fair and sweet and gentle was the young lady; very brave and wild was her lover-too wild, the old folks thought, for so sweet a girl. But love tamed the bold lover, and this proved the happiest of runaway matches. Many sons and daughters were born unto them, and-rare good fortune in this checkered life!all of them crowned their parents heads with honor. A more prosperous and respected family dwells not within the limits of the Commonwealth. One of the sons was the eaptain of our company at Manassas-the sturdy "Rifle Grays" of L_—. Brave as his sire, he rose to be lieutenant-colonel of the "gallant Eleventh," and now lies sick of a severe wound received in the fierce battle of the Seven Pines. How the years have sped since the night in which the lovers eloped from this old house! Many years have come and gone over the sleeping dust of the maiden who leaped out of that window. I remember her in the prime of womanhood, and she was sweet and gentle and beautiful then. The snows of seventy winters lie on the brow of the bold lover, but the fire of his youth is not spent, and he is passing the evening of his days peacefully away in the midst of his children, and his children's ehildren, honored and beloved by all. This happy romance always repeats itself to me when I seat myself at the foot of the "little stars," and look out of the window, and listen to the summer winds sighing through the leaves of the stout aspen which has grown up in the old wheatfield, now a verdant yard.

I shall not detain you with a minute description of the new house, which, as you know, is joined to the old 


\section{MY UNCLE FLATBACK'S PLANTATION}

by a covered passage. It is a more pretentious but far less substantial edifice than its humble companion. On the ground-floor there is a high-pitched parlorwhat has become of all the "drawing-rooms" we used to have five-and-twenty years ago, I wonder?-and over the parlor there are two chambers, also high-pitched, and above them a sizable garret. So you see this modern structure, which every thunder-gust shakes to its foundation, is tall enough to look down with contempt on the old house. But, notwithstanding the disparity in years and stature, the two seem to get along very well together. The hard, mathematical eye of a Yankee would be offended at the juxtaposition of so uneven a couple, but, thank God! we in Virginia are used to these incongruous architectural matches. It will be a sad day for us when there is any regularity about anything in Virginia. When people begin to build houses "on the square," they begin to calculate-or, to give the word its idiomatic meanness, "cack'late"-and when they begin to "cack'late," they begin to keep an account of expenses-which is the infallible premonitory symptom of the virus of Yankeeism striking into the bone. I don't want to live among no sich people. I want to go whar I kin build my house cattycornered, lop-sided, slantingdicular, bottom-upward, any way I please, and have no correct idea about nothing, 'cept politics.

The glory of the new house is the "big room," upstairs. This spacious chamber boasts four great windows which reach within six inches of the floorventilation in perfection! You are in the house and 
out-of-doors at the same time; may see everything, hear everything, and feel every wind that blows. On one side is the garden, and beyond it, a quarter of a mile away, is the railroad; which, seen in profile, looks like the key-board of an interminable piano-forte. This railroad is great company for us at Mountain View. It reminds us that we are in the world of busy life and motion, although we are nestled so snugly under the locusts that you can hardly see us, brave soldiers, as you rush to the wars. It affords an easy path to the village, and brings us every day a squad of convalescent soldiers, who walk out to get dinner and breathe the pure air. We are never tired of it. A locomotive under a full head of steam is always attractive. Every time a train passes, we all get up to look at it, and, if its speed is at all rapid, Uncle Jim seldom fails to exclaim, "I George! she's a goin' uv it."

Through the window on the opposite side of the big room, the vision is led down the sloping fields to the "low grounds," now groaning under a luscious load of watermelons, muskmelons, and cantaloupes, and thence to the river, whose lines of beauty are traced by masses of luxuriant foliage, so thickly do the trees and clambering vines crowd to the banks to drink the life-giving water, all muddy as it is during half the year. Ovei the river a hill mounts boldly up, and on its top a white house is perched, like a castle on the Rhine. Beyond the hill, far in the distance, are the knobs of the mountain. Almost at the foot of that mountain, the father of Uncle Flatback used to live -a Revolutionary soldier, seven years in the line- 
concerning whom and his hapless daughter, Virginia, you may one day hear more. The river side of the big upstairs room I like far better than the railroad side. The view is more extensive, more varied, rural, sequestered. The railroad suggests the busy world and all my cares away yonder in the city, crowded now with thousands on thousands of sick and wounded, and but lately delivered, thank God! from myriads of besieging Yankees. Whereas the river, rolling under thick-boughed trees, brings thoughts of freedom, peace, seclusion, the delights of bathing and fishing to the mind. Talking about fishing, there is the noblest beech, the best place for fishing, and, sometimes, the finest fishing in this little muddy river that heart could wish. I wrote a piece once about that old beech, and the fishing frolics $I$ have enjoyed while reclining on its fantastic roots, equal to any arm-chair, and under its scanty shade. When my collected works are printed, I want somebody to hunt up that piece, take out the nonsense and republish it-for there are some good things in it, I think.

But it is not for the peaceful view only that I like the river side of the big room so well. It is on account of the trees-the aspen close to the window, and the sturdy oaks that tower above the crank-sided carriage-house just outside the yard. Oh, me! what delight to lie by the window during the listless, midsummer days, and look at the aspens, all in a flurry of delight, and watch the lazy, fleecy clouds far up in the blue wclkin. And then at night to stretch out in the wide bed, or on a soft pallet down on the floor, close by the window, 


\section{MY UNCLE FLATBACK'S PLANTATION}

and look up at the stars through the gently moving branches, and listen to the murmuring, and whispering of the leafy creatures. I know not what they say, but I know they are talking. They have their secretstales of the old, old world, of the "joyous prime" of Eden, and that dread time when this planet was not ripe for man, but life was striving up to him through Nature's every manifestation.

You can't teach me anything about trees. I'm acquainted with 'em; have known 'em ever since I was a child, and used to spend whole days with 'em in the woods. I tell you they are people. Everybody knows that some trees are tame and others savage, barbarous, half-civilized, and so on. Put a pine-tree in a yard, and what does he look like-how does he feel? He looks out of place, and he feels embarrassed and mad, just as a negro field-hand would if you were to set him down in a parlor, or at a dimner-table in the midst of white folks. Whereas an aspen or a locust is perfectly at home in a yard, and throws out his arms affectionately toward the house, and tries his best to put a hand or two in at the window and pat you on the cheek with his leafy fingers. You think trees have got no soul, no mind, no heart. 'That's because you have got no soul yourself, plague on you! When a little bird hops on a twig, and begins singing as if he was singing for wages, the tree thrills clean down to his toes in the ground. So when the rain comes to fetch water, and the winds from away over the mountains and oceans come to tell the news, can't you see how happy the trees are, how they clap their hands and jump up and 


\section{MY UNCLE FLATBACK'S PLANTATION}

down, and get bright in the face, and actually laugh in the sunshine? If you can't its because the panes in the windows of your soul need washing. You think because trees can't walk they are an inferior order of beings. Well, now, if you think a bit, ain't you too stuck to this earth? Why don't you step over to the next star, and find out something that a tree don't know?

Men have a small opinion of trees because their hearts are set on money, stocks, fame, glory, and such trash; but boys think differently. Boys love trees. They love to play with them, love to climb them, because hugging is the principal part of climbing, and not the least portion of loving. And what's the reason boys delight so to ride saplings? Young things love to play with each other. Do the saplings enjoy it? Enjoy it! Now, look here. Do you want to provoke me to death? Did you ever ride a sapling? Well, then you have noticed that, after you have done riding, the sapling bends over for days and days. A man of sense would tell you the sapling continued to lean over because the "woody fibre," elasticity, etc., etc., and scientific so-forth. I know better. It's no such a thing. The sapling remains in the stooping posture because he thinks a game of leap-frog is going on, and is waiting for the next boy to come along; and having a long time to live (provided he ain't cut down to make a ridgepole of a hen-house, or a roost for turkeys), and being mighty patient and sweet-tempered withal, holds on tiil the pain in his back compels him to rise up again. Poor things! I have seen 'em waiting and waiting 
for days and days after the boys had gone off and forgot 'em. It makes me right down sorry to look at 'em.

Let me come back from tree-talk to the river againthe muddy Appomattox-whose waters are as ugly here as its name is picturesque. It sweeps around the foot of my Uncle Flatback's plantation in a wide, irregular curve, until its lines of dense foliage are lost to the view from the windows of the room "up the big stars." There is a wagon-way which runs in a straight line by the sweet-potato patch and the little barn down to the sandy low-grounds, which, year after year, bear those copious crops of watermelons, muskmelons, and cantaloupes for which Mountain View is famous. Just on the river bank there is a hut of pine poles, which might be taken for a hen-house if it were not so far away from the mansion itself. In winter time you might puzzle your brain forever to find the use of this hut; but in summer the protecting lines of string, stretching from end to end of the melon patch, and the numerous scarecrows, made out of Winston's old breeches and Polly's old petticoats, compel you to the just inference, viz.: that it is the guard-house of the dusky sentinels who watch over the precious fruit which cumbers the ground hard by. 'Lijah, or 'Lijy, poor fellow! before he died in the service of his country-working upon the fortifications around Richmond-used to keep watch here; but John was always Uncle Flatback's right-hand man in all matters pertaining to melons.

Of the merits of the Mountain View melons I can speak by experience, having eaten them a thousand times, more or less. My only regret is that I can't 


\section{MY UNCLE FLATBACK'S PLANTATION}

eat a thousand at a time. You know, dear reader, that there are certain occasions-deemed very sad by wise and elevated persons unlike ourselves-when this mortal nature gets the better of us, and the only perfect happiness seems to be in the unlimited indulgence of our animal appetites. Base, very base are we, when these sensual seasons overtake and master us. But-poor, pitiful worms of the dust that we are-such seasons will arise; and we have to knock under to them, just as we do to the periods of frost and sunshine. I have known the time, my virtuous and dyspeptic friend, when the highest bliss I could picture to myself was a cloudless summer day, about two years long, in the which the present despicable wretch now writing these lines did nothing but sit in his shirt-sleeves, under the shade of a mighty tree, and eat the ice-cold core of a vast, preposterous, and unbounded watermelon, from soon in the morning until midnight. Forgive me, forgive me, ye earthly saints who live not by bread alone, and who never have any bad thoughts; but the fact is, I do really feel sometimes as if I would like to eat or drink some particular good thing, right straight ahead for several consecutive centuries, without stopping even to take breath.

Under the locusts in the front yard there is a bench of a convenient height to be eaten off when a person is standing up. Here Uncle Flatback leads his guests of a summer evening, and drawing a great pocketknife, plunges it remorselessly into the delicious entrails of his green-ribbed victims, until a dozen or so are split wide open, and lie at the mercy of the mouth- 


\section{MY UNCLE FLATBACK'S PLANTATION}

watering by-standers. Pitch in freely, young men and maidens, but beware of yonder grizzly bearded priest of melons, whose sacrificial blade has opened this inviting expanse of vegetable meats for your behoof. His stern and oft-repeated "take keer uv the seed" is meant in earnest, I assure you. Incur not the wrath of the hospitable ancient, whatever you do; but eat till you can eat no more, and never mind your fingers and mouth, over which the sweet juice is rapidly crystallizing into sticky watermelon candy, for 'Liza -or Link, as the seed-saving ancient calls her-will be here presently with a bowl full of fresh spring-water, nice soap, and plenty of towels-the people of Mountain View being a cleanly race, and having a madness for towels, of which, to the best of my remembrance, there are never less than half a million on hand at a time.

Following the course of the river, you find below the watermelon patch a number of towering sycamores, rising out of a tangled thicket. In former years these trees used to be the resort and dormitory of that most graceful object of Southern skies-the "tukky-buzzard." It is said they were driven off by the cannonading of the first battle of Manassas, two hundred miles away-a pretty story, truly. Just beyond this "roost" there is a dam, over which the muddy water falls as naturally, if not as beautifully, as at Niagara. This dam feeds Morton's or Jackson's mill, a quarter of a mile down the stream; and this mill-a biggish pile of dusky weather-boarding, which once had some pretentions to the proud name of Merchants' mills, and 


\section{MY UNCLE FLATBACK'S PLANTATION}

the gable of which may be seen peeping above the luxurious foliage that lines the banks of the river-is one of the prettiest and most pleasing sights at Mountain View. For I am of Macdonald's opinion, that true happiness consists in living in the country and owning a little mill. Apart from the beauty of the big wheel in motion, there is a satisfaction in taking toll of your neighbor, a charm in the racket and the dropping corns of the hopper, and a sense of company in the continual recurrence of a nigger boy, perched on top of a meal-bag, far back upon the haunches of a sober-sided old family mare. Mills suggest peace, home, and plenty; and then I think the apparition of an honest, chunky, well-bred, respectful, and not too self-important negro miller, all covered with meal, at the door of the mill, is one of the finest sights in the world, next to a country blacksmith's shop in the night time. Yankees and English can write poems about their mills and smithies; why can't we of the South? I'll tell you; it's because we are too wretchedly lazy. Plague take it! if I had the leisure and the mill, or the blacksmith shop, I wouldn't ask anybody any odds, but write the poem myself. And I bet you what you dare, it would be a good one, and, what is more to the purpose, it would be Southern-so Southern that there would be no mistaking it. A Yankee would throw up the whites of his eyes on reading it. Consoun our Southern poets! they sing about everything except the things we common people most care about-the scenes and sounds of home, far in the depths of the uncontaminated country, where the little that is yet unpolluted 


\section{MY UNCLE FLATBACK'S PLANTATION}

by Yankee ideas and customs still remains. Our Southern poets all want to be like Shakespeare, who was a universal sort of all out-o'-doors and all over creation of a fellow-a man of no time and no country, but for all time and all countries-and in aiming to be Shakespeare, they succeed in being nobody at all. If they would quit straining at the heroic and the historical, kick Tennyson and all other models into the middle of next week, or elsewhere, and if they would content themselves with the homely, and come right down to the soil that gave them birth, they might do something. My judgment, which may be very valuable, for aught I know, is, that when a man thinks the afflatus is in him, his first business is to let books rigorously alone; his next, second, last, and only business is to go straight to mother nature, get in her lap, look deeply in her beautiful eyes, and listen finely to her voice (whispering to him alone), and then tell what he has seen and heard as simply and as musically as he can. Heretofore Southern poets have coveted the approbation of scurvy Yankee newspapers, and followed Yankee models, oh, shame! in order to gain it. One of the compensations of this frightful war is the deliverance of our literature from this bondage, and the birth of a school of poets truly Southern. Already Hayne, Thompson (J. R.), Timrod, and Randall have given us heroic songs, which belong to us and to us alone-born as they are of the inspiration bequeathed by martyred patriotslegacy priceless and immortal-and copied after no models. Better is yet to come, when time shall have hallowed and glorified the men and deeds of these 


\section{MY UNCLE FLATBACK'S PLANTATION}

fateful days. Who will sing Stonewall Jackson's elegy?

On the road from the mill-here, since this piece is to be as rambling and parenthetical as any Sterne ever wrote-let me stop a bit. The little one-storyand-a-half dwelling-house near the mill would make an exquisite pencil sketch or painting in water colors or in oil; it is one of myriads in Virginia. Porte Crayon had an eye for the grand and the comic, also a little imagination. He did partial justice to her mountain scenery, to the Dismal Swamp the indigenous beings of the rural districts, and the Virginia nigger in his manifold variety, from the conceited carriage-driver to the fat cook and the little black boy blowing a "blarther;" but he had no eye for the beauties of Virginia homes. Is it a marvel he deserted to the Yankees? Whoso will, let him partake freely of the moral conveyed in this digression.

On the road from the mill to Uncle Flatback's there is a beautifully secluded and delightful bridge. Big trees, dressed with wild, luxuriant vines, bend over and frame it in from the workday, cornfield world on either hand. It is a matter of life and death to cross this bridge except on foot, and its use as a crossing for vehicles has long since been abandoned. The neighbors who used to patronize the mill abuse Patrick Jackson, the mill-owner, for not repairing the bridge, and Patrick Jackson, in turn, abuses the neighbors for not furnishing the timber. Both parties, I think, deserve leather medals for being gloriously lazy Virginians, willing rather to let things rot, and break the legs of horses 


\section{MY UNCLE FLATBACK'S PLANTATION}

and the necks of niggers, than to get into a Yankee stew and a New England fease the moment anything needs mending, and to work madly over every crack and fissure, as if godliness consisted in patching, and the world would be blotted out of existence the moment it ceased to smell of newly sawed pine and fresh varnish. For my part, I hope the bridge will never be mended, but stay just as it is until the bumbler-bees-humblebees? not any, I thank you-I speak Virginian, not the lingo of Bosting, or even of Ingling (perhaps you'd like for me to say England. I be blamed if I do)until the bumbler-bees, and other borers, reduce it to wood-dust and scatter it atom by atom into the stream. As long as the bridge is in its present breakneck condition, Uncle Flatback's plantation will not be a thoroughfare for everybody who wants to take a short cut from the plank road to the old stage road to Richmond. I hate a place that is continually enlivened and afflicted by people travelling vaguely about in shackly buggies that can run along a road no broader than a hog path. There is no peace, no sense of ownership in such a place as that. You might as well have no place at all. The hands in the field are always stopping to look at these wandering vehicles, the axles of which invariably creak loud enough to be heard half a mile off. Like as not they'll break down right at your door, and the people will be sure to stay all night, and the unclean-nosed child in the buggy (there is always one of them) will give your children the itch or the measles, and the black girl who rides behind the buggy will make herself generally obnoxious by fascinating the 


\section{MY UNCLE FLATBACK'S PLANTATION}

boy that brings wood into the house. Even if the fugitive buggy don't break down, from the moment it heaves in sight, everybody in the house, the kitchen, and the quarters is in a fever of uncertainty as to whose buggy it is; and as it comes up slowly, a half-hour or more is wasted in conflicting and vain conjectures, until it passes by - the man, woman, child, servant, and horse all staring stupidly at you and all your folks, who are staring stupidly at them; and when the plaguy thing is gone and quiet is once more restored, its horrid creaking leaves you with a toothache and a crick in the neck, and starts old Ring, who ought to have been dead long ago, to howling, until you are mad enough to beat his brains out with the fishing-pole which you have been peacefully trimming. I am not lacking in the natural instinct of hospitality, but, Virginian as I am, if I had a place, by jingo! there should not be a gate in it-nothing but drawbars twenty poles high, and each pole fastened with ten thousand knots of the strongest, biggest, stiffest, roughest, and hand tearingest grape-vine I could find. The labyrinth of Crete would be a "main, plain road" compared to my place, and the labors of Sisyphus wouldn't be a circumstance to the labor of getting through it. As for bridges, I wouldn't have one, unless it was two hundred years old and half gone when it was first built. A log, a round, slippery $\log$, with the bark off, fastened high up in the crotch of a tall tree on this side, and stuck in the crotch of a still taller tree on the other side of the creek, is a good enough bridge for me. If people want to see me, let 'em swim like Leander, or wade like Cousin Sally 


\section{MY UNCLE FLATBACK'S PLANTATION}

Dillard. Maybe I'll have a "cunner" for them I like best, but further than that I will not go-no, $I$ will not-you needn't ask me.

Many pleasant evening strolls I have had to the old bridge, all by myself, leaning over the bewhittled and name-graven railing, thinking thoughts and dreaming dreams till the evening star arose and the whippoorwill began his chant. But the water under the bridge is not clear as crystal, swift as an arrow, and sparkling as a stream of diamonds-fit abode for Naiads and Undines-but muddy as the telegraphic despatches from Mississippi before the fall of Vicksburg, slow as an army wagon or a conscript making a charge, and full of all manner of nasty and confounded "mudkittens," "snap'n turtles," and snake-doctors. Still, I love to go there and look by the hour, not at the plague-taked water, but at the pendent vines, the intricate emerald umbrage cut daintily upon the azure ground of the sky, the many-shaped clouds, the ravishing dyes of sunset, and fancying what a great fellow I might be if I only had money enough to quit writing nonsense and stick resolutely to poetry and romance.

As you go from George Daniel's-I think I'd better write it Dannill's, that's the way Virginians pronounce the name-as you go from George Dannill's land to Unc' Jim's, the road runs close to the river bank, and through a dense growth of bushes, which, in former years, when the carriage could go on the bridge, and I used to go with Aunt Mary and Cousin Betsy to church, gave us no end of trouble; for if we dodged from one side of the carriage to the other, to keep the intrud92 
ing branches from scratching our eyes out, we were sure to encounter a set of branches still longer and more insolent, besides skinning our elbows-no small calamity to a body with as plump, fine arms as Betsy'sagainst the brass buttons by which the carriage curtains were fastened. Unc' Jim never had the address and hardihood to clear up this thicket, or to prune the pugnacious branches. So, Sunday after Sunday we had to run the gantlet and display our agility in dodging around a space not much larger than the inside of a coffee-pot-for the carriage was a Yankee carriage, as scrimp, meagre, and rickety as the cheap and wretched souls that made it. Woodson, the carriage-driver, when struggling through this bushy maze, used to imitate the most difficult feats of the ancient gymnast or modern India-rubber man of the circus, by tying himself into a double-bow-knot, and placing the top of his head on the bottom of the foot-board, so that only the small of his back and the tips of his knee-pans were visible. Since the "bustid" condition of the bridge has made church-going by the Jackson's mill route impossible, the thicket has been left to its own wild will, and has become as impenetrable as the abattis which Hooker vainly erected in the Wilderness. Well, I am not sorry. Trees, as I said before, are living souls; I love to see 'em grow, and it hurts me to see them destroyed merely to make room for people to pass. Why, I would like to know, can't we treat them as politely as we do other gentlemen of high standing? One vacation old Hart cut down a dead apple tree that grew by the fence which enclosed the playground 


\section{MY UNCLE FLATBACK'S PLANTATION}

at Edgehill. I saw the gap the moment I got back, and felt as if one of the boys had died. When Uncle Jim cut down the pines between the house and Israel Hill simply to get a better look at the train as it passed, it seemed to me as cruel and unwise, as if a tyrant had destroyed a fine army merely to get a view of a fast woman. I detest clearings and tree murderers of all sorts. The sight of a new ground makes me as mad as the devil. To kill a forest in order to raise a weed - tobacco-is to me the very climax of crime and folly. The depraved and irrational salivary glands of the human race have a vast deal of $\sin$ to answer for. They have played Mother Earth the same vile trick Lot's sons played on him; they have uncovered her nakedness; nay, worse, they have heaped hickory ashes and many chunks of burnt "bresh" upon her fair bosom, all for the sake of getting something bitter and dirty and dauby to make 'em spit, and keep on spitting the livelong day. Isn't it horrible?

Not a word-none of your sneers, gibes, retorts, and "physician heal thyself." I do smoke; nay, to my shame be it admitted, I even chaw a little. I own I am as bad as any of you. But that doesn't make tobacco any cleaner or the clearing of new grounds less murderous. You see you can't make anything out of me by your rejoinders and argumenta ad hominem. Cease, therefore, and throw that villanous plug in your coattail away, and don't clap the crumbs into your mouth in a moment of forgetfulness.

The fence that divides Dannill's land from Flatback's had a gate just beyond the thicket before men- 


\section{MY UNCLE FLATBACK'S PLANTATION}

tioned, and the staples-that's the name, I believe-of that gate, are driven savagely into the trunk of a young and very pretty beech-tree. Who was the unfeeling wretch that did this act of vandalism? Would that I had him by the Adam's apple or the scruff of the neck. Bad enough to treat an innocent lad of a tree in this way, but to make a gate-post of a historical tree is outrageous. On the bark of this beautiful beech-tree the letters J. R. are cut, and John Randolph of Roanoke is said to have cut them with his own hand. The tradition may be apocryphal, but yonder is "Bizarre," scarcely half a mile away, where Randolph lived for some years after his brother Richard's death-by the way, you know that Dick was a greater man than Jack Randolph, just as Bobus was greater than Sidney Smith-the same may be said of the almost unknown brothers of many eminent men-and our maltreated beech is on the road to "Sandy Ford," the mansion of the Dillons, famous in the old times for its hospitality, and a favorite resort of Randolph's. It is not at all impossible that, coming home from Dillon's, flown with, not insolence, but fried chicken and wine, and ruminating sadly on the certainty of his leaving no posterity behind him, he may have stopped his horse, and left his name to be perpetuated by this lusty young tree, which (albeit the gloomy engraver has been mouldering in his grave for many long years), seems hardly to have attained its adolescence.

After you leave Randolph's tree, there is nothing of interest on the road to old Flatback's-unless it be a muddy horse-pond under a little sycamore-until 
you come to the spring. It is a splendid spring, except in very wet weather, when the back-water of the Appomattox chokes it up, and it tastes of its own moss. 'It is shaded by oaks and elms-magnificent old fellows, that would set Virgil crazy were he to see them, and throw him into a bucolic equal to an attack of Asiatic cholera. Tityrus never recubed under anything comparable to them. It is a fine thing of a hot summer day to sit under these noble trees, recline your head against their mighty boles, and muse sweetly for a few minutes, until a caravan of gigantic black or red pismires begin a pilgrimage up your backbone-for the Virginia ant, as you are well aware, has a choice knack of getting under the "body-linen," as old folks call it, which sets wristbands and collar-buttons at defiance.

Hard by this spring there are some utilitarian fixtures which disclose the indifference of the true Virginian to æsthetics, and knock the sense of the beautiful on the very head effectually. They are fixtures used at hog-killing time. There are the rocks that are heated to put in the water that scalds their hair off. There is the pole on which the hogs are hung by the hind legs to be disembowelled. There they are, close to the spring of sweet water and right under that elm, the equal of which is not in all Virginia. You are a man of imagination, of course, and whenever you look at that pole, you see the naked porcine corpses hanging down, with a great gash in front, and a corn-cob in the open bloody mouth of each of them; and every time you look at these rocks, you smell burnt hair and feel bristles, and remember, as if it were yesterday, the first night 


\section{MY UNCLE FIATBACK'S PLANTATION}

you ever saw the plantation Crispin making low-quarter stitch-downs, and how funny it was to see a man sewing with two threads at the same time.

There are some jugs of milk of both kinds-sweet milk and buttermilk-in the spring-house, and Ada will be here presently to carry them to the house, for Aunt Mary is going to give us green-apple tart to-day; but the place reminds us of the hogs, so let's get away to the thicket of plum and thorn bushes, just over the grassy knoll above us. Double up your coat for a pillow and lie down awhile, and I'll tell you something. You see that old tobacco-house yonder? You do. Well, do you know that in all the Southern novels and poems that I ever read or heard of, there is not a line about tilted and sway-back old tobacco-houses or about plum bushes or thorn bushes? And do you know that I think there is a deal of romance and of poetry in these things? Why, the thorn bush is the home of the nightingale-did you know that? No, you know nothing and care less about these very romantic things! I knew you didn't. You are Virginian, and, since childhood, you have ceased to care about plums-wild plums, I mean. You say the skin is bitter and the things get squashy as soon as they are ripe. You think thorn bushes were made especially to furnish negroes with vegetable buttons to fasten "galluses" by, and as for old tobacco-houses, you are too busy making new ones to think about them at all. Very well, sir, if these are your prosaic views, you can just get up from under Uncle Flatback's pretty plum bushes and go with me to dinner, and eat butter-beans until you burst-fit end for you, you miserable matcrialist. 
As we go by the kitchen and the quarters, I shall not allow you to talk with Malindy, who is cooking for the hands, or with Polly-for dinner is late-or with Locky, who is ironing like mad-she is a real steam-engine, Locky is-you shall interrupt nobody, but go straight along into the yard and do your best to appease the ire of Uncle Flatback, who threatens momentarily to "skin the head" of Liza and Cary Ann, if they don't "hurry up that mush." As for me, I will go into the garden.

No, I am not going to read you a long rigmarole about the garden-not if I can help it-although, on the principle of praising the bridge, I ought to do so; for many and many a good meal this garden has furnished me. It is an unpretentious garden; has no palings, you see; only a rail fence. The reason of this is this-Uncle Flatback rents the place, and won't go to any unnecessary expense about it. If he owned it, he would fix up things nicely enough; but, like every true Virginian, he has been on the eve of moving to Alabama, or Mississippi, or Texas, ever since he first came here-twenty years ago. Butter-beans, snaps, green peas, beets, cabbage, and a few flowers make up the contents of the garden; other vegetables, such as tomatoes, onions, black-eye peas, cymlings, and "rosin" ears, being grown here and there, first in this and then in that patch, in various parts of the plantation - a curious and peculiar feature of old-fashioned Virginian management.

About gardens and orchards-by the way, there is no orchard at Mountain View, because, in the first place, Uncle Flatback is afraid his apples and peaches might be made into liquor of some sort, and in the second 


\section{MY UNCLE FLATBACK'S PLANTATION}

place, he is continually going to go to Texas or elsewhere-about gardens, orchards, clover and wheat fields, there is something to be said which I have never yet heard said, namely: they are (to me at least) proofs. of the existence, wisdom, and goodness of Deity, better and more convincing than Paley's watch, or any other argument from design ever excogitated by the philosophers. Just think how ready to the hand all fruits, vegetables, and grains grow. Suppose you had to plant a ladder against the pole every time you wanted to get a dish of snaps, or to send a man up in a balloon to get your apples, or to cut through trees two feet thick, in order to harvest a crop of corn, or to sink a shaft whenever you had sweet-potatoes for dinner. What a hard old world to live in this would be, if a man had to blast out his turnips, or make use of a patent Yankee stumppuller to get at each separate head of clover, or to worry his asparagus out of the earth with the aid of a jack-screw! Then how easy it is to shell peas and peel peaches; why, you can mash soft peaches with your mouth, without peeling them at all. Think what intolerable botheration it would be to crack open watermelons with a sledge-hammer, or to saw through peahulls as you do cocoanuts. Pursue the idea, my frient, and the next time you see a cucumber, or a pumpkin, or cymling lying invitingly on the ground, as much as to say "here I am, ready for you," thank the Lord for all his goodness.

The garden looks toward the railroad, and on both sides of the railroad you sce a number of negro calsins, which you can take to be Uncle Flatback's 


\section{MY UNCLE FLATBACK'S PLANTATION}

quarters. No such thing. They are relics of a grand experiment at emancipation made some forty or fifty years ago by Dick Randolph. Like most of the men of his day, Dick throught slavery a great evil, and at his death manumitted his negroes, gave them plenty of tolerably fertile, well-timbered, and well-watered land, parcelled it off into small farms, gave them stockfarm implements, etc. The negroes looked upon their landed estate as new Canaan, and called it "Israel Hill," by which name it goes to this day. They had the advantage of years of slavery, which civilized and Christianized them; habituated them to labor and taught them the mode of raising crops. They had, moreover, the advice and assistance of white neighbors, all of whom, at first, regarded the scheme with scarcely less favor than Randolph himself, and were disposed to aid the negroes in any and every way possible. The experiment was fairly made. Its failure was signal.

In this year of grace, 1862, the population of Israel Hill is scarcely so great as it was forty or fifty years ago, when the inhabitants entered the new Canaan. Had they remained slaves, their numbers would have been quadrupled. As it is, they will doubtless die out in the course of a few years and disappear, as they have done in Gerrit Smith's and so many other Yankee experiments at colonizing free negroes. One or two of the Israel Hill families exhibit in their abodes and crops some capacity for self-improvement; the rest are thriftless, to say the least. Men and women alike earn a precarious subsistence, laying up nothing and spending much of their earnings in drink. One of their number, 


\section{MY UNCLE FLATBACK'S PLANTATION}

the patriarch of the Hill, old Uncle Sam White, now considerably more than one hundred years of age, is so remarkable that a bare outline of his character would require a separate article. A more honest, upright man, a more truly pious and devoted Christian, cannot be found in this whole Confederacy. A cheerful old man, his laugh, as he walks along the railroad and stops to speak with his acquaintances, may be heard for half a mile. He is, withal, a gentleman of the old school, full of a century ago, in the house of his aristocratic master; and, previous to the war, while wine was yet attainable, never failed to set his decanter out when you entered his humble cabin. No man, white or black, is more respected in his neighborhood than this genial, honest, Godly minded old man; and when he goes to his long home, as he must soon do, there will be more regret for his loss among the whites than among the people of his own color.

Let me now come back, if I possibly can, to Mountain View, and close this discursive and tiresome article with a brief account of old Flatback himself. $\mathrm{He}$ is the son of a lieutenant of the American Revolution, who entered the ranks as a private, and fought through the war, and bore upon his person the mark of an honorable wound. This son of his served in the War of '12, as a private in the Virginia line, marched from the Valley to Ellicott's Mill, but was never in any engagement. True to their parentage, his sons have played a manly part in the great struggle against the North. When the war broke out, one of them was in Texas. He hurried home, joined Garnett's command, and, by the acci- 


\section{MY UNCLE FLATBACK'S PLANTATION}

dental discharge of a pistol, fell at Rich Mountain, before the disastrous battle at that place occurred. The other has been in the war from the beginning, and, if he is alive, is still a private in Stuart's cavalry. I am told that the Prince Edward troop, raised by the gifted and ill-fated Thornton, contains no better soldicr and no greater favorite, than William Flatback.

With all his eccentricities of dress and behavior, old Governor Flatback-he is called governor in compliment to his real or fancied authority over his nearest neighbors, the sable residents of Israel Hill-is greatly liked and respected. The young men, and the old as well, of the neighboring village, are never tired of joking him about his temperance hobby, his belief in the medicinal virtues of white-oak bark, and many other odd notions. He takes a joke generally in good part, and is not unskilful in returning the rough compliments of his assailants, but is at times quite hot-tempered and excitable-which makes the fun of teasing him all the more pleasant to his persecutors.

Besides being a great temperance and white-oak bark man, he is a great raiser of watermelons and cornfield peas. It was at his house that I was first made acquainted with the superlative virtues of that peculiar variety of the cornfield pea known as the "grey crowder"; and as for his melons, their fame has gone forth to the ends of the earth-with slight limitations. In addition to these claims to greatness, he was, in his youth, a mighty fox-hunter, owned the best pack of hounds in the country, and bred and trained a series of the most remarkable dogs, all named "Redcoat," that 
ever lived. Le Roi est mort; vive le Roi. The dog died, but Redcoat survived. When the first Redcoat expired his son fell heir to the title, and so on for I know not how many years. In the same way there was a succession of terriers named Bob, the property of the governor's second son, James, who died, as before stated, at Rich Mountain. The last Bob, a sober-sided, gentlemanly dog, who travelled with his master to Kansas and back, may be seen to this day at Mountain View, a mournful reminder of the generous-hearted young man who loved him so fondly, for whose sake he is cherished and petted to the serious detriment of his health-for overfeeding has produced a cutaneous disease that worries him incessantly, and has made him gnaw nearly all the hair off his hind quarters. To tell the wonders performed by the Redcoat lineage would require a volume. If my Uncle Flatback's fond memory may be trusted, no such dogs ever lived before, or ever will live hereafter. Lightning on four legs might rival their speed; anything less fleet they could distance easily. Like the lama of Peru, mentioned by the showman, who "travels at the rate of forty miles a minute-pigeon tied to his tail can't keep up"they were considered as rather rapid than otherwise. With regard to their noses, it is enough to state that they did not consider a trail cold until it was six weeks old and ploughed up at that. The music of their voices was so exquisite that Uncle Flatback declares it invariably cured him of a raging toothache, or loekjaw, or hydrophobia, or some such infirmity to which he was subject in his hunting days. 


\section{MY UNCLE FLATBACK'S PLANTATION}

It remains only to speak of Governor Flatback's kindly heart and open-handedness and this is no easy task to one who has experienced so much of both as the writer of this fatiguing sketch. To say that he is hospitable, after the good old fashion of Virginia hospitality, is to praise him but lightly, for that virtue is still common to all who inhabit the Old Dominion. But the assertion so often and so falsely made of many men, that no one in want ever left his door emptyhanded, is literally true in his case. His family, like himself, seem never so happy as when they are performing some friendly and generous deed. Nor is theirs a half-way performance. I will give a single instance in proof of the whole-souled way of doing things in the Flatback household.

Late one evening, about five years ago, my aunt came running to the house in great alarm. She had been frightened by a strange-looking man who was approaching the house. This man soon made his appearance. He was a sight to see, indeed. A mass of rags saturated with water enveloped an emaciated frame, and under an immense shock of matted hair peered forth a haggard face, the picture of death. He was a poor Irishman, making his way on foot to a distant city. While trudging the railroad he had been taken ill, had applied at various houses for lodging, and had been refused, no doubt because of his frightful appearance. In this condition he had been forced to lie out in the rain for two consecutive nights; had dragged his way to Israel Hill, where the negroes directed him to Governor Flatback's, as perhaps the 
only place in which he would be sure of finding a shelter.

Most people would have been satisfied with giving the poor man supper and a night's lodging; but this was not the Flatback way of doing things. The next morning he would have pursued his journey. No; the Flatbacks would not hear of it; he must stay until his clothes were washed, and until he got stronger. James Flatback took him in charge, gave him a good bath, cut his long, tangled hair, rigged him from the skin out in a suit of his own clothes, filled his pipe with good tobacco, and put him in the yard under a tree to dry. I never saw a man so improved. He had an honest, intelligent face, and sat under the tree in a state of high enjoyment.

No sooner had he finished smoking than a big Flatback watermelon was pressed upon him, and this, of course, brought on an attack of the ague and fever, which had seized him some days before. He was put to bed, treated with calomel and quinine, and very soon got upon his legs again. But the chills had hardly subsided before a galloping consumption came on, and we expected every day to see him die. It was pronounced by a competent physician a case of genuine pulmonary phthisis, and no one expected him to live. The poor fellow suffered horribly. As he lay in the little room adjoining my uncle's chamber it was fearful, during the paroxysms of expectoration, to hear him alternately cursing and praying for death to release him from his pangs.

Brandy (in spite of old Flatback's prejudices against 105 


\section{MY UNCLE FLATBACK'S PLANTATION}

liquor), cod-liver oil, and whatever else was needed, was supplied ad libitum, and six weeks after, to our utter amazement, Paddy rallied and gave unmistakable evidence of an intention to live. He did live. Skilful treatment, good nursing, and generous living cured him, and for three years he occupied the little room next to my uncle's, working whenever it suited him, and entertaining Governor Flatback, who became very fond of him, with stories of his adventurous life, with recitations of poetry, and with a never-failing flow of Irish humor. Soon after the war broke out he joined the army, became one of Jackson's "foot cavalry," was in the great campaign of the Valley, from NcDowell to Fort Republic, got wounded in the battles before Richmond, visited Mountain View during his convalescence, received a hearty welcome, and returned to his command, where he is to this day, for aught I know.

Such are the Flatbacks. If they had not overwhelmed me time and again with kindness; if the patience of people who read were inexhaustible, and if paper were as cheap as the Flatbacks are generous, I should make it a point to allude to them, casually at least, if not favorably and at length. As it is, I must dismiss them with a simple "God bless 'em," as a people too warm-hearted and unworldly for serious notice in so brief and pointed an article as this. But if time, Yankees, Confederate taxes, and things generally, spare me, I intend some day to do them justice, and to make the Flatbacks and myself as famous as Willis's Mountain, Beard's Old Tavern, or the Masonic Ihall in Curdsville. 


\section{IV}

\section{MY WIFE, AND MY THEORY ABOUT WIVES}

$\mathbf{W}^{\mathrm{E}}$ do not marry our own wives! We marry the wives of somebody, of anybody else, and anybody or somebody else marries our wives. It may sound very funny and very silly to say this, but it is the plain, hard truth, and nine out of ten married men will, in their secret souls, admit it. I repeat it, we don't marry our own wives; and all the lawyers, legislators, judges, jurists, statesmen, philosophers, physiologists, and phrenologists on earth can't make us do it, if we chose. And I believe we would choose, for I have a good opinion of human nature. This is a puzzle for the spirit-rappers-a riddle which even the Fourierites cannot solve. Speculation, ratiocination, imagination, no mental faculty or process will avail us here. I doubt if that "internal apperception at a depth within the penetralia of consciousness to which Kant never descended," of which Cousin boasts, will mend the matter. But the reason is very plain to me. It was not intended for us to marry our own wives; "God's last best gift is reserved" unto another higher life; elsewise this earthly existence would of itself be heaven. And now you know what I mean by "wife." Not 
merely your wedded spousc and lawful mother of your children, but that woman-soul, fashioned by God himself as the one only partner and complement of your soul; truly the "better half" of your inmost self; with whom you are perfect man, without whom you are but an unhappy segment, more or less dimly conscious and complaining of your incompleteness. You see I am a believer in the exploded theory of "matches made in heaven." Yes, I am; for I have seen four such matches in my life, and I do not exaggerate when I say that, for them, the millenium has already come. But I have been lucky; for such matches are exceedingly rare, most people never having seen them at all.

Not only do we not marry our own wives, but frequently we never so much as see them, or, if we do see them, don't know them. On the other hand, a man may see his wife and know her to be his wife, but his wife may not know him, may never know him in this life; vice versa, the wife may know her husband and never be known by the husband, and so on. I wish to record my experience on this subject; and if $I$ do so in a somewhat frivolous style, it must not be inferred that I am not in earnest; the inference might be false-" many a true word is spoken in jest."

It follows, or may follow, from what has been said, that we are all married. Yes, that is my opinion. Now, in the eye of the law and of society, I am a bachelor, with every prospect of remaining a bachelor; but in point of fact, and in the eye of reason, I am a married man-just as much of a married man 
as Brigham Young is; the only difference between us being that his wives are visible, or to speak philosophically, phenomenal, while my wife is not, except, as before said, in the eye of reason-particularly my reason. I say again, and most emphatically, I am a married man; I say so because I know my wife, that is, I know her name and have seen her twice. I have never been introduced to her, never spoke a word to her in the whole course of my life, and never expect to. She doesn't know me from a side of soleleather, probably never heard of me; and if I were to go to her and tell her she was my wife (which is the fact) would have me put in jail or a mad-house. But, poor thing! that's no fault of hers (she being entirely ignorant of my theory, and of the eye of reason also), and she is my wife, to the contrary notwithstanding.

The first time, which was the next to the last time, I ever saw her was about three years ago-three years ago exactly, next February. It was in the town of Plantationton-a little, old, drowsy town situated on the banks of a little muddy river, with a long, ugly Indian name. The stage in which I was travelling at the eventful time stopped in Plantationton, and the stage-passengers dined there in a rusty old tavern, with a big, worm-eaten porch, and a gangrenous, cracked bell. I got out of the stage, feeling very cramped-up and dirty, and straightway betook myself to a tin basin (there were half a dozen more on the old, hacked-up bench), full of clear, cold springwater, by the help of which and a piece of sticky turpentine soap I managed to make a very respectable 
ablution. My face washed, I applied it for a few minutes to a long, greasy, ragged old linen towel that hung up on a roller fastened to a scabby, old weatherboarding; then I parted my hair with the half of an old horn comb that was tied to a string, and smoothed it with a little, old wiry, worn-out hair-brush that was tied to another string; and then I was ready for dinner, which was not yet ready for me. Pending dinner, I sat down in a split-bottomed chair, elevated my heels, leaned back, took out my knife, and commenced paring my nails. I had seen the little old town frequently before, and didn't care to see it again, especially on a miserable, gummy, eloudy, damp, ehilly day in February, and so confined my attention for some time to my fingers, of which I am rather proud. But, fortunately for me, I heard an old fellow behind me say, "By dads! she's beautiful"; and looking up, saw the young lady alluded to. I wish to Heaven I had never looked down! She was standing exactly opposite me, in the front door of a dried-up wooden store; her head was turned up the street, as if she was looking for somebody, and her little foot was patting the sill with the sauciest, sweetest impatience imaginable. That young lady was my wife! I didn't know it then, but I know it now.

She was beautiful-bewitchingly beautiful-so beautiful that for a long time I did not know I was looking at her-didn't know I was looking at anything-didn't know anything. The joy of her presence was flowing in one uninterrupted stream through all the avenues of sense, and it was not until my soul became full to the brim of her beauty that I could say I saw at all. 
Whether she was dressed in silk, barège, delaine, or calico I could never tell, and never cared; I remember only her little bonnet of simple straw-neat, trim, and vastly becoming, as the bonnets of pretty women always are. She was young-not more than eighteen-rather above the medium height; of round and perfect figure; her hair was golden and her eyes were blue; her complexion pure as light itself, fresh as the dew, and glowing as the dawn. She must have felt the many eyes feeding on her cheek and brow, for she turned presently, and how instantly the impatient little foot disappeared, how archly modest the smile that illumined her lightly blushing face! I could read her character at a glance. She was warm, and tender, and true; good, wise, merry, healthy, happy, sweet-tempered, willing, patient, loving, tidy, thrifty, and sincere, and everything a wife ought to be or could be. Why didn't I know she was my wife? Why didn't she come over and tell me so? Alas! we were both blind-and she remains so still!

There I sat, drinking my fill of beauty-inhaling bliss at every breath. How little did she dream of what was going on in my soul! How could she tell that her radiant image was effacing all other images from my heart, to be itself effaced for a time, but only to reappear in the hallowing and charming hues of memory - the one solitary and sufficing ideal of my unblessed life! She saw me gazing at her, but only as she had seen hundreds gaze before.

A primrose, 'mid the tavern's stir,

A yellow primrose was to her,

And it was nothing more. 
I was only a sallow-faced young man, with a black mustache and a deal of impudence. I didn't look like her husband a bit; but I was her husband for all that-I know I was.

Fair reader, let us here moralize a little. But no; I am not good at that, and, besides, I am too prolix anyway. Yet remember, beautiful maiden, and be watchful of your looks; for, all unknown to yourself, you may be shaping for life, and perhaps for life beyond life, the destiny of some ill-looking biped who glares at you from the opposite side of the street!

All the other stage-passengers, and all the tobaccospitting loungers about the tavern, were gazing at her as well as myself; she knew it, too-the little rogue! - and was pleased, as she ought to have been. She ceased to look for that somebody up the street, who never came, and stole a sweet, bright glance toward us, as if to say, "I can't help being pretty, indeed I can't. I am glad you think me so, and you may look as long as you please; I sha'n't charge you anything."

Bless her sweet little soul! Every man on that porch ought to have bent his knee in homage to so much beauty and goodness.

But the confounded dinner-bell rang, and the beasts in broadcloth rushed to their food just as any other beasts would have done. I am ashamed to confess it, but a most unromantic sense of propriety smote me the moment I heard that accursed bell. "It is out of the question," said I to myself, "for you to be staring that young lady out of countenance; get right up and go to your dinner. It is true, you may never see so 
beautiful a face again, but then, you know, your health is delicate, and it won't do to neglect so important a meal as dinner. You have a long and wearisome ride before you; besides, she don't care anything for you, and even if she did, you are in no condition to marry."

Thus did mere animal cravings prevail against the sweet appeals of beauty; and thus (as the last clause of my mental argumentation abundantly shows) did my mind unconsciously refuse to entertain the possibility of a rejection, and so assert the truth of the statement I have made, namely, that she was my wife. The world will call this vanity, but I call it intuition or spontaneous, unconscious apperception. With great reluctance I rose as if to go; she saw that all except myself had gone, but still stood in the front door of that dried-up old store, patting the sill once more with the tip of her tiny little slipper. She was so good that she could not refuse to gladden even one poor mortal with the light of her blessed countenance. It flashed across my mind that I might save fifty cents by missing my dinner; avarice had come to the aid of beauty, and I sat down again. But hunger (yes, miserable human that I am, it was hunger) defeated them both.

Ah! if I had only known then as much as I know now, how differently I would have acted. I would have dismissed the contemptible subject of dinner, and, having summoned a waiter, would have addressed him thus: "Boy, do you see that old red trunk in the boot of the stage yonder? Well, just take that trunk off; I am so pleased with your lovely village that I intend to stay here until I get married." The young lady 
on the opposite side of the street would have heard me; it would have produced a deep impression on her (and first impressions, you know, are everything); I would have remained in my seat until the young lady left; I would have eaten my dinner in peace; afterward I would have donned my new doeskin breeches and my new black coat; then, by hook or by crook, I would have procured an introduction to my wife; and after a while I would have married her-there's no doubt about it. Although I was poor, her beauty and her love would have made me rich; my love for her would have made me strong and able to work; by this time I would have acquired a standing in society-I would have been happy.

But I sold my wife for a mess of pottage-I went in to dinner. When I reached the door of the diningroom I hesitated, went back to the porch, and commenced gazing at my wife as before. She saw me, and gave me a smile; upon my honor she did. It was the sweetest smile I ever received. I may have valued smiles before, but it is certain I have never valued one since. Whatever made me return to the dining-room after receiving so great a favor I could never remember. It was so fated. I did go back to the dining-room, hurried through my dinner, which had become cold and indigestible, and hurried back to the porch. She had gone!

The stage was waiting for me; I jumped in, and it rattled out of the little old town. We had not gone many miles before the consequences of hasty ating brought on a terrible attack of dyspepsia. I became 
painfully aware that I had lost my dinner and my fifty cents; but I did not know I had lost my wifeI forgot her! I was returning, after a long absence, to my native city, to enter upon a new and untried profession; and there were a thousand things to occupy my attention, to the exclusion, not only of wives, but even of sweethearts. So I lost my wife and didn't know it! And so, I imagine, most of us lose our wives.

About a year and a half afterward; that is, about one year ago, having failed in business, as an aimless, unmarried-that is, phenomenally unmarried-man is very apt to do; though it doesn't make much difference if such a man does fail, especially after he has lost his wife-having failed in business, I say, and having nothing to do, I returned to Plantationton, not in the stage, but in the cars, the railroad having been in the meantime completed. So completely had my wife gone out of my mind, that I did not once think of her when I sat down in the old tavern porch and looked over at the dried-up little store, in the door of which I had seen her patting her little foot so prettily. I ordered a buggy and drove out to my uncle's, about three miles from town, and spent many pleasant weeks there during the hot summer months. Being a young man of a marriageable age, my relations very naturally offered to introduce me to the marriageable ladies of the neighborhood. I expressed my willingness. Which sort did I fancy-fair or dark, blonde or brunette? Fair, by all means; who ever heard of a sallow man fancying a woman of his own complexion? Oh! then, I ought to have been here a year ago; there was a young 
lady living in town, a great friend of ours, perfectly beautiful, and the very best girl in all the world, who would have suited me exactly. Ah, who was she? Miss Jenny So-and-so. Jenny! the very name I want my wife to have; describe her to me. They described her. It was the identical young lady I had seen standing in the old store. I became excited, and my pulse rose as I asked the question, "Where is she now?" "Oh! she has been married a long time to Mr. Thingamy, and lives now in the city of Jacksburg, about a hundred miles from here." My pulse sank, not because I knew she was my wife (that is quite a recent discovery), and I had lost her, but for the good and sufficient reason (which authors have but lately had the honesty to avow) that every bachelor feels himself defrauded when a pretty woman marries. From the bottom of my heart I wished Mr. Thingamy and the city of Jacksburg had been at the bottom of the sea before they ever had heard of the beautiful Miss Jenny. I felt indignant she should have displayed so much haste to get married; and I refused to be introduced to anybody in the neighborhood of my uncle's. But whenever conversation (as it will often do in the best of families) turned on the subject of young ladies, my uncle's family were sure to bring their favorite Miss Jenny forward as a paragon of beauty, sweetness, goodbreeding, good everything. As often as this would happen an unaccountable depression and feeling of loneliness and bereavement would come over me, and last for hours. I can now account for it-it was the as yet inarticulate, unintelligible premonition-a species 
of spontaneous, unconscious apperception-of nature, protesting against, and at the same time preparing me for, the full consciousness of the great loss I had sustained in losing my wife. My uncle had named a beautiful kitten after her; do you wonder that I petted Jenny, and fed her and caressed her every day I rcmained in the country? I do not. I am naturally fond of cats, and that, they say, is a sign I am going to be an old bachelor. Well, what if it is?

When the summer was ended, I left my uncle's and returned home, still ignorant that I had lost my wife, and forgetting her as before. For nearly a year I knocked about among the young ladies, falling now a little in love, and then falling out again; charging mysclf with fickleness and want of decision of character, and wondering greatly why I could not fall really in love with anybody. Poor fool! I didn't know that there was nobody left to love; I was married and didn't know it. Many a man is in the same fix.

Things remained in this condition until about a month ago, when, having failed a second time in business, I concluded to spend another summer at my uncle's. The cars dropped me at Plantationton; I went to the same old tavern, sat down in the same old porch, in the same old split-bottomed chair, and looked over at the same old store, and there, by Heaven! stood my wife, in almost the very spot I had first seen her. She was waiting for her husband, who was following with the nurse and child. Her husband was a dark-skinned fellow-almost as dark as myself, and not very unlike me. I have since expended some 
severe thought on this resemblance between me, the spiritual husband, and Thingamy, the phenomenal husband of my wife, and it is perfectly plain to $\mathrm{my}$ mind that, under the influence of the same spontaneous, unconscious apperception, she was trying her very best to marry me; in fact, did marry as near me as she possibly could. How that fact has made me love her!

The whole party had come down on the same train with me, and I had not known it. Fate again. They stood opposite me for some time, apparently resting, and I had the second and last (I know it will be the last) long, good look at her. She was greatly changed. No longer the same buxom, blooming girl I had seen years before, patting her pretty foot against the sill, but a beautiful woman, infinitely lovelier than the girl; pale, but beautiful as the bright fulfilment of the perfect day is beautiful-more beautiful than the rosiest hues of the uncertain dawn; thin, but beautiful, as thought and loving cares beautify and make delicate mere matter; older looking, but possessed of that ineffable charm which only the realization of woman's destiny can impart to woman. I gazed on her, not with breathless admiration as at first, but with calm, intelligent adoration. Positively, hers was and is the sweetest human face in all this world. Nothing, absolutely nothing was wanting from those pale and gentle features; they expressed all that a wife and mother ought to be. And even as I gazed, there came into my soul that strange pain of vacuity and deprivation-a numb and formless hurt-which needed only the light 
of reflection to assume the acuteness of thought, the permanence of knowledge.

From that day I have known she was my wife; how I knew it, and why I knew it, has been told already, or if not told, never will be, for it never can be. The knowledge or conviction, if you prefer to call it so, grows on me; it increases with the increasing light of morning, is revealed in the splendor of high noon, deepens in the pensive summer twilight, and rises with the tutelary stars. The winds tell of it to the melancholy trees; the waters repeat it with their many liquid voices. It is written in cloudy hieroglyphs upon the distant sky; it is the shadow thrown upon the plain of life by the sun of hope which sinks behind my heartenlarging and to enlarge, darkening and to increase in darkness until the night of death. It is-but I am getting absurd.

Shall I remain a bachelor? dwindle down and shrivel up into an old bachelor? Never! Since I cannot marry my own wife, I'll marry the wife of somebody else; and if I could only find the wife of the man who married my wife, I'd marry her in spite of fate. And if I could only ride about in the cars with a plenty of nurses and children, and Thingamy could see me and know my theory, I should be perfectly satisfied.

Dear reader, take warning by me; study my theory; it was written for you, and for the whole human race. Try to cultivate your spontaneous, unconscious apperception. And if ever you sit down in an old tavern porch and see a beautiful young lady on the opposite side of the street, don't wait for dinner, but go right 


\section{MY WIFE, AND MY THEORY ABOUT WIVES}

over and demand her in marriage. You may be mistaken; she may not be your wife; she may be already married; but no matter, it is your duty to make the effort. If you don't, you'll regret it; you will find yourself in my predicament. You may see me any day struggling through the weeds of my uncle's wheat-field, looking and feeling unutterably mean. No wonder; I have lost my wife! 


\section{V \\ FISHING IN THE APPOMATTOX}

A BEECH grows askant the Appomattox that A curves around the foot of Uncle Jim's plantation. The stream, generally muddy, is clear now as a maiden's eye. Deep under the bushy banks, it flows with a still surface, but a strong current, a moving mirror, that reflects the fair October skies, and every limb and leaf of the overhanging trees in beauty not their own, for, under the perfectly outlined forms of branch and spray, drooping vines and fluttering leaves, lie the mysterious, immeasurable depths of heaven. 'Tis a strange feeling that comes over a man as he looks down, down into those depths, so fathomless so wondrous lovely, and yet so near at hand-the cunning trick of light reflected from calm water. You come back with a start when you remember how simple it all is.

The beech I spoke of is of great age. Poor old soul! he has seen his best days; he is dying now. As he bends over the water, with his lean uplifted arms stretched out, he reminds me of an old fellow putting on an overcoat that is too tight across the shoulders for him. I fancy I can hear the big, piteous splash he 
will make when he topples over into the river, and can see his great corpse floating along, the naked limbs thrust up appealingly, helplessly, from his watery grave, till the negroes come and catch him, and cut him up with brutal axes, and burn him in their quarters 'way into the long winter nights. But, thank goodness! the old fellow is tough and gristly; he will hang on the bank many and many a day yet, and I hope to catch abundance of flatback from under his sheltering boughs before he takes his final plunge.

The best thing about the old beech is this: leaning over so far from the bank, the better to look at himself, no doubt (he must have been vain of his personal appearance in youth, and I don't wonder at it, nor blame him a bit), leaning over in this way, he has been compelled to send out a tremendous growth of roots to hold on by. All gnarled, twisted, and interlaced, these roots form as nice a rustic arm-chair as heart could wish-the best place to fish you ever saw. You can sit down, lean back, rest your feet, do anything you please. Then the seat is so perfectly clean. And it is nicely shaded, too. With your pole fixed in a crevice right at your hand, you can smoke or read, prepared in a moment, when a mullet nibbles to take him.

As Uncle Jim's plantation was once a part of the "Bizarre Estate," this old beech has a historical value. I look upon his roots with great respect. Jack, and Dick, and Judy, and Nancy Randolph have reposed their aristocratic bones on these same roots often and often. But I look upon these roots with awe. In the far past, a mightier race than the Randolphs was here. 
Indians and Randolphs alike are gone; we shall see them no more. In fact, I never saw them at all; but I am pleased that mine eyes have dwelt their humble glances on those venerated roots, so honored in the days of yore.

It is early in the morning when "me and Billy Ivvins" and the other fellows set forth in the direction of the old beech. The air is crisp and cool. One of the fellows has a double-barrelled gun. The morn, like an eastern queen, is sumptuously clad in blue and gold; the sheen of her robes is dazzling sunlight, and she comes from her tent of glistening, silken, celestial warp, beaming with tender smiles. Billy Ivvins totes six slender pine poles on his left shoulder, and a cymling full of the best and biggest fishing worms in his right hand. The woods, painted in all the gorgeous dyes of autumn, repose on the distant hills, their tops trembling in the fresh breeze. One of the party carries a cold ash-cake to bait the hole with. The day is beautiful exceedingly. The veil of dusky silver, the haze of Indian summer, is rent in twain, and we see nature face to face, in the unclouded glory of her beauty-

Sweet day! so calm, so cool, so bright, The bridal of the earth and sky.

I've got two splendid Woodall pipes, plenty of firstrate smoking tobacco, and a box of German matches in my pocket. It is a day of days for flatback, provided the moon is right. Flatback won't bite on the wane of the moon; nothing but nigger-knockers bite then-nigger-knockers and eels. 


\section{FISHING IN THE APPONATTOX}

However, we are going to try, moon or no moon. Billy Ivvins swears that the planetary bodies have nothing to do with fish-it's all confounded superstition.

Arrived at the beech, the lines are quickly unwrapped from the poles, the hooks (Sutherland's best) are baited with two long worms each, a few crumbs of bread are cast in to keep the roach and other little fish busy; out go the sinkers as far to the middle of the stream as the poles will allow, the corks after wabbling for a little while settle down and set jauntily on the water; the poles are fastened between the roots, and the irrepressible piscatorial conflict begins. Billy Ivvins leans against the trunk of the old beech; next him is Billy Y., then comes Dr. X., the best fisherman of the party, and, lastly, myself, perched far out on a projecting root. They tell me the root is rotten, and that I will fall into the water; but I know my weight better. The fish don't bite fast. I predict that we are going to have bad luck. Billy $\mathrm{Y}$. does the same thing. Billy Ivvins swears that we are "boun' to take 'em." Dr. X. sits perfectly silent. We all watch our corks: no movement. A desultory talk springs up, mainly about the Harper's Ferry affair. Billy Ivvins swears that an attempt will be made to rescue "old Brown." "He is of the opinion that the country is full of abolitionists; says that these oil-cloth and table-cloth men that tramp about the State are nothing but emissaries of the underground-they ought all to be hung. And all these Northern preachers, professors, and schoolteachers, that we have amongst us, ought to be made to swear an oath of allegiance to Virginia, or else be 


\section{FISHING IN THE APPOMATTOX}

immediately killed. He thinks "Gizzard" the very man for the present crisis. Ding 'em! he'll swing 'em. Gizzard's good grit as ever fluttered. If Brown is acquitted, he (Billy I.) will be one of twelve men to follow him and shoot him on sight, wherever found. Brown ought to be hung, drawn, and quartered, his head stuck over the penitentiary, and the rest of him suspended in trees in various parts of the State, a terror to all who behold.

"The militia ought to be thoroughly organized. He wondered why old Gizzard had not done this before. Fine every man ten dollars who don't attend muster," etc., etc.

Dr. X. thinks he has a nibble, and begs Billy to stop talking, which he does reluctantly.

We all admire the glorious weather, the lovely day, the sweet seclusion by the riverside, under the beechen boughs, with the fresh wind pouring its invisible flood over our heads as we sit under the bank, and shaking down a Danæ shower of golden leaves from the trees.

There is a plenty to interest and charm us beside the world of inanimate nature around us.

The tree tops are full of robins eating grapes. How they chirp, and flutter, and shriek, and dash about! as if half afraid and altogether delighted, like a parcel of school-girls bathing in a shallow creek. Crows by the hundred wing their level flight over the field back of us, cawing as they go. They are preparing to hold a caucus in the pines over there. Here comes a gust of blackbirds. They wheel impetuously, and alight in an instant, as if drilled, high on the limbs of a dead birch- 
tree right opposite us, on the other side of the river. There they are, all in a lump, the black rascals, looking at us as unconcernedly as you please. It is as much as we can do to keep Billy Y. from banging away at them. But it will never do to scare the fish. Whew! robins and blackbirds go off in a tumultuous cloud.

What's the matter now? Aha! No wonder you flew so quickly, my little fellows. There's a hawk, a big gray one, comes swooping on noiseless wings out of the sky. By jingo! he's lit not forty feet from us. Shuh! he's gone, without a sound, before Billy Y. can get to his gun. "Hallo! hallo! what's that?" "Otter." “Otter the devil-it's a mus'rat. No, 'taintit's a duck." " "Taint a duck either, it's a didapper." "There he is; there he is; I saw him when he rose." Billy Y. is after him; but he might as well try to shoot a witch without a silver bullet. We hear his gun go off, and he comes back presently bringing a field-lark in his hand, the yellow breast all rumpled, and the brown wings hanging limp and lifeless.

Meantime Dr. X. has caught one or two fish-small ones-whitesides. Billy Ivvins, in great wrath, has pulled out a hideous nigger-knocker, and I have had a glorious nibble. Billy Y. is in bad luck; not a thing has touched his "stopper"; he is restless, and keeps moving about, to the great annoyance of that exemplary fisherman Dr. X., a model of quietness and taciturnity. Billy Ivvins swears that Billy Y. has got the "evil hand," and that's the reason the fish won't bite at anything he has touched. Whereupon I make a 


\section{FISHING IN THE APPOMATTOX}

pun, and say that Billy Y.'s evil hand has given his pole the pole-evil. Billy Ivvins swears he will kill me for a fool.

We hear a squirrel barking down the river, and the "evil hand" goes after him, and brings him. The fish are beginning to bite pretty well-one or two medium-sized flatback have been landed by Dr. X. Again there is silence, interrupted only by the restless and unlucky Billy Y., and two little negro girls who are picking peas in the cornfield across the river. The corn has been topped, and stripped of its broad fodder blades, each stalk holds out a heavy yellow pouch, giving promise of endless pone for the coming year. A slight rustle is heard in the weeds over the way. Perhaps the partridges are there- a glorious flock, not less than a hundred, have grown up in Uncle Jim's plantation during the summer, and have come down to spend the fall in the low-grounds. But while we look, a small inquisitive head, with a Roman crest, and an eye half hidden in a white circlet, peers out of the weeds; and presently a sinuous, graceful neck is lifted high, disclosing a breast cuirassed in blue, burnished steel; it is a lordly peacock, with his mate, anxiously inquiring the meaning of those strange forms seated on the old root over against him. And now a shadow with expanded wings is seen in the limpid depths of the stream. We look up, and lo! far. far aloft in the bright October heavens there floats, on stretched unmoving pinions, a buzzard-that hungry black republican democrat of the skies-surveying the wide territory below him, intent on practical squatter 
sovereignty, and seeking where he may intervene to protect the carcass of a deceased cow or mule. Several of them, belonging to Uncle Jim, having paid the forfeit of too deep affection for poisonous mushrooms, now lie stark and cold in the pines beyond the tobaccohouse. Billy Y. proposes "unfriendly legislation" in the shape of three fingers of shot; but as it is important to preserve the harmony of the party (the fishing party), Senator Douglas-I beg pardon, I should have said the buzzard-is permitted to go on his way unmolested.

Our lines are continually disturbed by dead leaves. They appear to love to hang around the corks, like a parcel of red-nosed topers round a bottle. As they come sailing down the river, myriads in number, and of all the hues of the rainbow, one can't help thinking that somebody has split a quilting up the stream, and is naturally anxious to see the girls, and find out how the accident occurred. I'll bet there are some boys up there, and that the quilting frame, baskets of scraps, etc., got upset while a tremendous romping was going on.

"Hush!" says Dr. X. (Nobody has said a word.) "I've got a bite," he goes on, calmly; "that's a flatback. I know by the way he bites, and I shall certainly catch him." We look-the cork gives scarcely a sign, and the next moment out comes a dripping ingot of silver, glistening brightly in the sun. The ingot proves to be a goodly flatback, and is soon thrown high and dry on the bank. Billy Ivvins swears that the p'int of his hook is out, and that's the reason 
the fish haven't bit at him this half-hour. He pulls at length, and up comes a tolerable sized flatback, who had been quietly sucking all the time. Now I have a decided nibble. "It's nothing but a roach," says Billy. "Give him plenty of time," says the doctor. So I wait till I can wait no longer, and then jerk; and by Jove! it's a splendid mullet. The fish are beginning to bite in earnest; everybody catches them except Billy with the "evil hand"; not even a niggerknocker will bite at him. And the fish get bigger and bigger, pull stronger and stronger. Soon the doctor hangs a whaler-a flatback sixteen inches long. How he pulls! How he bends the pole! "Let him play, let him play!" is the cry, and we all draw out our lines to give him room. At last he is wearied out; the doctor draws him to the surface, and he lies fully exposed to view, a prodigious fellow. He has given up entirely and struggles no more. Just at this crisis, the hook slips out of his side where, it had accidentally caught, and the noble fish is lost. But flatback magnus don't know he is loose. There he lies, resigned to his fate. A second more, he wriggles his tail and darts out of sight under the water. There is a general outcry of disappointment and vexation. But all we have to do is to make up for lost time; so we throw in again, and it is not long before we are rewarded for our pains. The fish we are catching now are all of good size, twelve or fourteen inches long, and upon my word they do pull gallantly. It is equal almost to trouting. Billy Ivvins swears that the flatback in this hole are superior to any other in the river-they are of pure Castilian blood, 
game and mettlesome as a wild horse when he is first lassoed.

"Is that the cars?" Yes, it is the train from Lynchburg. It is half-past one o'clock-high time for dinner. And while the roaring of the train is still in our ears, here comes Aunt Lockey from the house, with a heavy basket, little Ada staggering behind her under the weight of a big bucket of fresh spring-water. An old plank makes a good dinner-table; the plates and dishes, with excellent fried ham, chicken that needs only a little salt, sweet-potatoes, bread, and sweet pickles, make up the repast, which we devour with hearty relish, watching our corks all the time. But the fish are too well-bred to interrupt gentlemen while they are dining. There's not a single bite until we are through with our meal and have lighted our pipes. Even then the fish trouble us very little. Doubtless they are taking a siesta, for it is a well-known fact that fish never bite well from after dinner until an hour or two before sunset. We wait patiently. The slant sunbeams creep around the little tree to our left, and fall upon the water above the pool.

The biting commences again, but I am clilled and go up the bank to walk about and warm myself. As the fish are tossed up, I can but admire them. The "flatback," you know, is called "sucker" in some parts of the country, and, with its broad, mottled, green back, its large fins and black eyes, makes as pretty a fish as any that swim in our waters. It is easily caught, if you have patience. The mullet is a beautiful fish. Its glistening sides of silver mail and its 
broad, purple fins, are a delight to look at. All fish are beautiful, on account of their clean, healthy look; but these we are catching seem peculiarly so. What unpolluted blood flows in their veins! how free they are from the aches, the ills, the slow, consuming diseases of human kind! They owe no money, buy no clothes, pay nothing for board, rent no houses, are never taxed, never have any accounts at the dry-goods stores, are never troubled about bonnets for their wives, or schooling for their children, own no land and no negroes, care nothing about old Brown, are not at all excited about the election in 1860, and don't have to get up, of a cold winter's morning, and wash their faces in a tin pan. It is a sin and a shame to drag them out of their homes into this dirty upper world. How soon their glory departs, their lustre fades! Their silver coats are soon begrimed with dust, and even their round, undefended eyes, are filled with it. Pity, pity, they haven't got eyelids. I declare it hurts me to see them flapping vainly to get back into the water, as they lie gasping and panting on the bank. And how sorrowful their poor mouths look-did you ever notice them?

Another name for the nigger-knocker is hogfish, and it is by far the ugliest tenant of the Virginia waters. Catfish are sweet and pretty compared to niggerknockers. They have a mean poisonous look. Their heads are ragged and hideous beyond expression, reminding me of the stump of a thumb after the end has been blown off by a pistol, more than any thing else I can think of.

But now the shades are deepening fast; it is getting 131 
really cold; the water, with its dark reflections, looks like a wondrous picture in Indian ink. We hear the dull tinkle of the bells, as the cows pace slowly to the "cuppen." Still, the fish bite. We can scarcely see our corks, but we are loath to leave. Billy Ivvins hangs a monster flatback; he pulls like mad; as he rushes to and fro under the water, the pole bends like a bow, and fairly cracks under his struggles; but Billy Ivvins knows how to manage him. At last he is completely exhausted, and struggles no more. Cautiously, slowly, Billy draws him up; he is fairly out of the water, a glorious fellow, eighteen inches long at the very least, and hangs as still as death. But ere his tail is six inches from the water, the treacherous snood snaps, down he drops, and is gone for ever. You just ought to have heard Billy Ivvins swear. I have heard many men curse, such as congressmen, hack drivers, and gamblers, but none of them ever equalled Billy Ivvins on this occasion-

"No ancient devil,

Plunged to the chin, when burning hot,

Into a holy water pot;

Could so blaspheme, or fire a volley

Of oaths so dire and melancholy,"

as Billy Ivvins fired when that snood snapped and that flatback fell back into the Appomattox.

But now we are compelled to leave. We fix up our tackle in haste, and put out at high speed, one of the party carrying the mighty string of flatback, mullet, and nigger-knockers; the others taking charge of the 
guns, etc. A little way down the river bank, we discover what appears to be a bundle of fodder set up on the end to scare the fish away from three or four poles that hang over the water. It proves to be Uncle Jim, in a battered wool hat and a sun-cured old overcoat, with his feet wrapped up in a blanket to keep them warm. The old fellow has displayed his skill by catching nearly as many fish as all of us boys together. Adding his fish to our string, we set forth again at a topping pace, to start the circulation, which has become stagnant by long sitting on the beech root. Besides, it is very cold.

By the time we reach a snug little bachelor establishment, the stars are sparkling in the skies, and we are warm as toasts from the rapid two-mile walk. Supper is soon served. We partake of it sparingly and go to Farmville to hear old Joe Sweeny. We find that the old fellow has let down; but he is welcome to our small change for the sake of what he used to be when he was young and in his prime.

After the concert is over we repair to the Randolph House, take a good big drink of excellent Bumgardner - a whiskey that is said to have power almost to raise the dead. We pay our respects to Messrs. Pryor and Goode (it is the night before election day), and find both of them pretty well used up, and accordingly leave them to their much needed rest. We return to the bachelor establishment, and about eleven o'clock sit down to a magnificent flatback supper; and we enjoy it as only Appomattox flatback fishermen can enjoy it. At the close of his tenth cup of coffee, Billy 


\section{FISHING IN THE APPOMATTOX}

Ivvins looks over a lofty pile of flatback bones, and gets very sick. He swears that flatback is the greatest eating in the world. He wishes he may be teetotally dad-blasted into everlasting dad-blamenation if they ain't superior even to shadses. The skulls of flatback parched would make splendid coffee. Flatback is the meat of all meats for married men to eat. He intended to get him a large wagon and fill it with flatback, and get married and start in the morning for Texas, etc., etc.

And so ended the great "ketchin' of flatback, mullet, and nigger-knockers, in the Appomattox." 


\section{VI}

\section{AN UNRENOWNED WARRIOR}

THE RECORD OF A MAN WHO SHIVERED THROUGH THE MANASSAS CAMPAIGN.

F X-GOVERNOR JAMES L. KEMPER tells a war C story that is so very good I think he must have invented it. Yet it is so true to nature that it ought to have happened a hundred, nay, a thousand times. He says that on the night of the retreat from Williamsburg in 1862, when men and officers were mixed up indiscriminately in the muddy road, with the rain falling heavily on them, and no man knew his neighbor, a soldier near him (General Kemper) pulled himself out of the mire, and going up to the fence on the roadside dropped his musket to the ground, and, in accents of the most intense sincerity, exclaimed:

"Well, if ever I love another country ag'in, damn me!"

Much the same feeling came over me the first night I slept, or tried to sleep, at the new fair-grounds, in the suburbs of Richmond, which had been turned into a camp of instruction, and was called Camp Lee. $\mathrm{M}_{y}$ friend, Lieutenant Latham, of Lynchburg (afterward Acting Judge Advocate General of the Army of North- 


\section{AN UNRENOWNED WARRIOR}

ern Virginia), and I slept under the same blanket on the upper floor of one of the fair-ground buildings. The month was April, the night was chill, the air keen, the blanket thin, the planks hard. Moreover, I had eaten freely of hard tack and drunk still more freely of cold water, which was bad for my dyspepsia.

Truth is, there was a big disgust upon me, more on account of my "sojer clothes," I think, than anything else. Nature had not fitted me for a roundabout with brass buttons-a fact which the young ladies discovered as we marched past them and their waving 'kerchiefs on our way to Camp Lee. Besides, I had always thought "sojering" tomfoolery anyhow. So when the night wind blew keen upon my ribs, my purpose to love any more countries diminished as sensibly as did the soldier's on the Williamsburg road, though I did not formulate it in such spirited terms as his. Yet I loved my country, I verily believe, as much as any man on the ground at Camp Lee-would have died for her; but not by freezing, or, worse still, by filth. Of this last, more anon. That others shared my feelings was proved by V. Dabney. In consequence of his huge bulky figure, his jolly good nature and his fund of wit, $\mathrm{V}$ - was a conspicuous figure in the camp. He had been raised in luxury. His father, a rich Mississippi planter, had lavished money on him, and actually urged him into extravagance. His ideal of life was a hotel in Paris, and this sort of thing didn't suit him at all. But his sense of duty was supreme.

"Boys," he would say, as he took his short meerschaum from his mouth and drew up his robust figure 
to its full height, "Boys, I want you distinctly to understand - this is my last war! This is my first, and I am going to see it through to the bitter end, but after this no more war, no more sleeping in straw for V. D. No, sir!"

He was as good as his word. He went through the war, rising to a captaincy on the staff of Gordon, of Georgia, and now teaches school in the city of New York.

"Sleeping on straw!" Aye, that was the rub. To be sure we had ticks, but they were about as thin as the insect of that name; there were about nine of us to a tent-good large Sibley tents we had at first-and not a night-shirt among the whole nine. Reveille was another misery. I was three-and-thirty years of age, a born invalid, whose habit had been to rise late, bathe leisurely, and eat breakfast after everybody else was done. To get up at dawn to the sound of fife and drum, to wash my face in a hurry in a tin basin, wipe on a wet towel, and go forth with a suffocated skin and a sense of uncleanness to be squad-drilled by a fat little cadet, young enough to be my son, of the Virginia Military Institute, that, indeed, was misery. How I hated that little cadet! He was always so wide-awake, so clean, so interested in the drill; his coat tails were so short and sharp, and his hands looked so big in white gloves. He made me sick. What the deuce did I care about learning how to "hold my piece," to "load in nine times," and all that? I was furious; but at the same time I got up a big appetite for breakfast, which was generally good, for we lived pretty well at Camp Lee. 
I recall a single incident at Camp Lee. The company next to ours was from Campbell County, I think, and composed almost wholly of illiterate countrymen. Hearing an animated conversation going on toward their camp-fire one night, I drew nigh and listened. The causes that led to the war were being discussed, and the principal speaker, a sergeant, gave an account of the formation of our government and the true theory of its working on States-rights principles that would have done credit to a constitutional lawyer. On inquiry I learned that this sergeant was by trade a plasterer, and what he knew about the government he had learned from stump speakers. He was a pretty fair specimen of the average Confederate soldier, who knew what he was about when he entered into the war.

One morning news came that we had been ordered to Manassas. It was true. I was glad-anything for a change.

Garland's Battalion, afterward the Eleventh Virginia Regiment, was the first organized body of troops sent to Manassas. The battalion was composed of Company A, the Rifle Greys; Company B, the Home Guard (both of Lynchburg); the Fincastle Rifles, a Campbell County company, and possibly one from Pittsylvania County, but I cannot be certain. All that I remember is that there were four or five companies. There was some little grumbling in our company, and, perhaps, others, when it became known that Garland was to command the battalion, and this discontent deepened when he obtained the appointment of colonel. It was loudly whispered that he had intrigued for the 


\section{AN UNRENOWNED WARRIOR}

appointment. No one doubted his capacity, for he was a graduate of the Virginia Military Institute, and a young lawyer of remarkable intelligence, but, unfortunately, he "lacked grit." Whereas, said the grumblers, the captain of Company A, Maurice S. Langhorne, was, like all the other Langhornes, brave as a lion.

This was the talk. I give it as an illustration of the mistake constantly made at the beginning of the war, that animal bravery was the main requisite in a soldier. What a mistake! Bullies ever ready for a brawl repeatedly proved arrant cowards on the field, while the cowards, so-called, turned out to be the most gallant and skilled of soldiers. Samuel Garland was neither coward nor bully, but a refined, scholarly gentleman, whose courage in action was so conspicuous and whose capacity so marked that when he fell at Boonsboro', in the second year of the war, he was acting major-general, and deemed one of the most promising young officers in the whole army. In his native city his memory is sacred; he is beloved and revered beyond any soldier that left that portion of the State. His name is never mentioned without honor and tenderness.

It must have been mid-day or earlier when we left Richmond on a train of box-cars, with tents, camp equipage, etc., amid great cheering and enthusiasm for this, mark you, was war, real war, and no fooling about it. Oh! what asses men are! as if that were anything to be jolly about! We went slowly along, pausing at every station to let the girls see us, give us bouquets, and wave their handkerchiefs at us. Being 


\section{AN UNRENOWNED WARRIOR}

an invalid, I was allowed a seat in a passenger car with the officers, but as the hot May afternoon wore away I felt worse and worse. It was night when we reached Gordonsville, seventy-six miles from Richmond, and then occurred a long halt. Dr. Chalmers, who had heard me complain about my throat, came to my seat and felt my pulse.

"You have decided fever," said he, "and the best thing you can do is to get out here and lie over till you get well. I will leave some medicine with you."

Words more welcome never issued from mortal lips -no, not even when my lady-love said "yes." 'There was a good hotel at Gordonsville-it is there now, and I never pass it without a benediction-kept by a man named Omohundro, who was called "M'hundrer" for short. Into that hotel, and upstairs to a second story room, I hurried with all speed. "Wouldn't I have supper?" inquired M'hundrer. No, but a bucket or a tub of hot water by a negro boy.

The bathing over-how I enjoyed it! I dismissed the boy, put on a night-shirt that had been dying for three weeks-at least I had been dying for it-blew out the light, a wood fire was on the hearth, and got into bed. The sweet languor of fever was on me, the warm bath had softened my whole nature, bodily and spiritually, my skin began to breathe once more, the odor of the clean pillow-cases was more delicious than roses or lilies, and as I stretched myself out at full length I actually tasted the clean sheets clear down to my toes. You may talk about happiness, but there is no greater happiness than I experienced at that 


\section{AN UNRENOWNED WARRIOR}

moment. What heaven may be I know not, but that was heaven enough for me. I blessed Chalmers for advising me to stop, blessed the negro boy, blessed M'hundrer, the hot water, the pillows, the sheets, the whole world, and went to sleep vowing that never again while life lasted would I sleep in anything but clean sheets, be the eonsequences what they might to the Southern Confederacy.

I remained there two or three days, taking as little medieine as possible and getting well as slowly as possible. During my stay a number of trains went by on their way to Riehmond, laden with the spoils of the arsenal and workshops at Harper's Ferry-guns, ammunition and machinery that were invaluable to us.

I believe that Garland found Captain Lay with a part of the Powhatan Troop at Manassas-eertainly the plaee had been pieketed for a few weeks-but that was all. Its strategic importance seemed to have been overlooked. On my arrival I found the boys comfortably quartered in tents and enjoying the eontents of boxes of good things, which already had begun coming from home. In a little store at the station they had discovered a lot of delieious eherry brandy, which they were dispatching with thoughtless haste. Rigid military rule was not yet enforeed, and the boys had a good time. I saw no fun in it. The battalion drill bore heavily upon me; Garland eonstantly forgot to give the order to shift our guns from a shoulder to a support. This gave me great pain, made me very mad, and threw me into a perspiration, which, owing to my feeble circulation, was easily eheeked by the eold 


\section{AN UNRENOIVNED WARRIOR}

breeze from the Bull Run Mountain, and thereby put me in jeopardy of pneumonia. Moreover, I longed for my night-shirt and the clean bed at Gordonsville. The situation was another source of trouble to me. After brooding over it a good while I got my friend Latham to write, at my dictation, a ketter to John M. Daniel's paper, the Richmond Examiner. The letter was not printed, but handed to General Lee, and additional troops began to come rapidly-one or two South Carolina regiments, the First Virginia Regiment, Captain Shields's company of Richmond Howitzers, Latham's Lynchburg Battery, in all of which, except the regiments from South Carolina, we had hosts of friends. The more men the sicker I got, and the further removed from that solitude which was the delight of my life. I made up my mind not to desert, but to get killed at the first opportunity. I might get a clean shirt, and would certainly get, in the grave, all the solitude I wanted.

Beauregard soon took command. This was a comfort to us all. We felt safe. About this time, too, the wives and sisters of a number of officers came from Lynchburg on a visit to the camp. That was great joy to us all. Lieutenant Latham's little son, barely two years old, and dressed in full Rifle Grey uniform, was the lion of the hour. The ladies looked lovely. Such a relief after a surfeit of men; our eyes fairly feasted on them. Other ladies put in an appearance from time to time. Returning from Bristoe, where I had gone to bathe, my eyes fell on three of the most beautiful human beings they had ever beheld. Beautiful 


\section{AN UNRENOWNED WARRIOR}

at any time and place, they were now inexpressibly so by reason of the fact that women were such a rarity in camp. They were bright figures on a background of many thousand dingy, not to say dirty, men. If I go to heaven-I hope I may-the angels themselves will hardly look more lovely than those young ladies did that solitary afternoon. I was most anxious to know their names. They were the Misses CareyHetty and Jennie Carey, of Baltimore, and Constance, their cousin, of Alexandria. No man can form an idea of the rapture which the sight of a woman will bring him until he absents himself from the sex for a long time. He can then perfectly understand the story about the ecstatic dance in which some California miners indulged when they unexpectedly came upon an old straw bonnet in the road. Pretty women head the list of earthly delights.

Over and over I heard the order read at dress parade, all closing with the formula, "By command of General Beauregard, Thomas Jordan, A. A. G." This went on for some weeks without attracting any special attention on my part. At last some one said in my hearing: "Beauregard's adjutant is a Virginian." I pricked up my ears. "Wonder if he can be the Captain Jordan I knew in Washington? I'll go and see," I said to myself. Colonel, afterward General, Jordan received me most cordially, dirty private though I was. He was, as usual, very busy. "Sit down a minute. I want presently to have a little talk with you." My prophetic soul told me something good was coming, and, when, after some preliminary talk about unimportant 


\section{AN UNRENOWNED WARRIOR}

matters, he said: "So you are a "high private in the rear rank?",

"Yes," was my reply.

"Aren't you tired of drilling?"

"Tired to death."

"Well, you are the very man I want. Certain letters and papers have to be written in this office which ought to be done by a man of literary training, and you are just that person. I'll have you detailed at once, and you must report here in the morning. Excuse me now, I am very busy." Indeed, he was the busiest man I almost ever saw, and to-day in the office of the Mining Record, of New York, he is as busy as ever. A more indefatigable worker than General Thomas Jordan it would be hard, if not impossible, to find.

My duties at first were very light. I ate and slept in camp as before, reported at my leisure every morning at head-quarters, and did any writing that was required of me, General Jordan's clerks being fully competent to do the great bulk of the work in his office. The principal of these clerks was quite a young man, seventeen or eighteen, perhaps, and was named SmithClifton Smith, of Alexandria, Va. - and a most assiduous and faithful youth he was. He is now a prosperous broker in New York. After midnight Jordan was a perfect owl; there were always papers and letters of a particular character, in the preparation of which I could be of service. We got through with them generally by one A.M., then had a little chat, sometimes, though not often, a glass of whiskey and water, and then I went back to camp, a quarter of a mile off, not 
without risking my life at the hands of a succession of untrained pickets. At camp things were comparatively comfortable. The weather was so warm that most of the men preferred to sleep out-doors on the ground. I often had a tent to myself. Troops continued to come. Many went by to Johnston (who, to our dismay, had fallen back from Harper's Ferry), but many stayed. Water began to fail, wells in profusion were dug, but without much avail, and water had to be brought by rail. Excellent it was. Boxes of provisions continued to come in diminishing numbers, but upon the whole we lived tolerably well. The Eleventh Virginia, its quota now filled, had gone out on one or two little expeditions without material results. It formed part of Longstreet's Brigade, and made a fine appearance and most favorable impression in the first brigade drill that took place. How thankful I was that I was not in it!

During these days when the camp of the Eleventh Virginia was comparatively deserted, the men being detailed at various duties, there occurred an episode which will never be forgotten by those who witnessed it. Coming down from head-quarters about one o'clock to get my dinner, I became aware as soon as I drew nigh our tents that something unusual was "toward," as Carlyle would say. Sure enough there was. In addition to the ladies from Lynchburg, heretofore mentioned, we had been visited by quite a number of the leading men of that city, who came to look after their sons and wards. Several ministers, among them the Rev. Jacob D. Mitchell, had come to preach for us. 
But now there was a visitor of a different stripe. The moment I got within hailing distance of the captain's tent I heard a loud hearty voice call me by my first name.

"Hello! George, what 'll you have? Free bar. Got every liquor you can name. Call for what you please."

Looking up, I beheld the bulky form, the duskyred cheeks and sparkling black eyes of Major Daniel Warwick, a Baltimore merchant, formerly of Lynchburg, who had come to share the fortune, good or ill, of his native State. He was the prince of good fellows, a bon vivant in the fullest sense of the term, a Falstaff in form and in love of fun. What he said was literally true, or nearly so; he had all sorts of liquors. In order to test him I called for a bottle of London stout.

"Sam, you — scoundrel! fetch out that stout. How'll you have it-plain? Better let me make you a porteree this hot day."

"Very good; make it a porteree."

He was standing behind an improvised bar of barrels and planks, set forth with decanters, bottles, glasses, lemons, oranges, and pineapples, with his boy Sam as his assistant. The porteree, which was but one of many that I enjoyed during the major's stay, was followed by a royal dinner, contributed almost wholly by the major. This was kept up for a week or ten days, officers and men of the Lynchburg companies and invited guests, some of them quite distinguished, all joining in the prolonged feast, which must have cost the major many hundreds of dollars.

The major's inexhaustible wit and humor, his quaint 146 


\section{AN UNRENOWNED WARRIOR}

observations on everything he saw, his sanguine predietions about the war, and his odd behavior throughout, were as much of a feast as his eatables and drinkables. He was the greatest favorite imaginable. Everything was done to please him and make him comfortable, including a tent fitted up for him. Being much fatigued by his first day's experience as an open barkeeper, he went to bed early, the boys all keeping quiet to insure his sleeping. Within twenty minutes they heard him snoring, and the next thing they knew the tent burst wide open and out rushed the corpulent major, clad only in his shirt, and as he came he shouted at the pitch of his stentorian voice: “Gi' me a'r, gi' me a'r! For God's sake, gi' me a'r!" Of course there was a universal burst of laughter, which the major bore with perfect good nature. Thenceforth he slept on a blanket under the canopy of heaven, enjoying it as much, he declared, as a deer hunt in the wilds of western Virginia. He carried with him, when he left, the Godspeed of hundreds of hearts grateful for the abundant and unexpected happiness he had brought them.

This was that same major who cut up such pranks in New York City a few months after the war ended -picking up a strong negro on the street and forcing him to eat breakfast with him at the Prescott House, imperiously ordering the white waiters to attend to his every want, then walking arm in arm with the negro down Broadway, each having in his mouth the longest cigar that could be bought, and puffing away at a great rate, to the intense disgust of the passers-by. Of this freak I was myself eye-witness. In the restau- 
rants he would burst out with a lot of Confederate songs, and keep them up till scowls and oaths gave him to understand that it would be dangerous to continue, when he would suddenly whip off into some intensely loyal air, leaving his auditors in doubt whether he was Union or secesh, or simply a crank. In the street-cars and omnibuses he would ostentatiously stand up for negro women as they entered, deposit their fare, gallantly help them in and out, taking off his hat as he did, and bitterly inveighing against those who refused to follow his example. So pointed were his insults that his huge size alone saved him from many a knockdown. He lived too merrily to live long, and died in Baltimore in 1867, I believe.

Ever since the fall of Sumter Beauregard's star had been in the ascendant. His poetical name seemed to carry a magical charm with it. Jordan had implicit faith in him. Many others looked upon him as likely to be the foremost military figure of the war, and were prepared to attach themselves to his fortunes. Keep'ing my place as a private detailed for duty in the adjutant's office, I contented myself with a simple introduction to the general, and did not presume to enter into conversation with him-a privilege most editors would have claimed. (I was then editor of the Southern Literary Messenger.) But I availed myself of my opportunity to study this prominent character in the pending struggle. His athletic figure, the leonine formation of his head, his large, dark-brown eyes and his broad, low forehead indicated courage and capacity. Of his mental caliber I could not judge, but others 


\section{AN UNRENOWNED WARRIOR}

spoke highly of it. He indefatigably studied the country around Manassas, riding out every day with the engineer officers and members of his staff. He was eminently polite, patient, and good-natured. I never knew him to lose his temper but once, and then the occasion was ludicrous in the extreme.

Just before the battle of Manassas the militia of all the adjoining counties were called out in utmost haste to swell our numbers. A colonel of one of the militia regiments, arrayed in old-style cocked hat and big epaulets, came up a morning or two before the battle and asked to see the general. When General Beauregard appeared, he said with utmost sincerity:

"General Beauregard, my men are mostly men of ramilies. They left home in a hurry, without enough coffee-pots, frying-pans, and blankets, and they would like, sir, to go back for a few days to get these things and to compose their minds, which is oneasy about their families, their craps, and many other things."

Beauregard's eyes flashed fire.

"Do you see that sun, sir?" pointing to it.

"Yes, sir," said the colonel, in wondering timidity.

"Well, sir, I might as well attempt to pull down that sun from heaven as to allow your men to return home at a critical moment like this. Go tell your men to prepare for battle at any instant. There is no telling when it may come."

The colonel retreated in confusion.

Beauregard's high qualities as an engineer-most signally proved by his subsequent defence of Charleston, compared with which the reduction of Sumter 
was a trifle-were acknowledged on all hands. What he would be at the head of an army in the open field remained to be seen. It was a trying time for him; but if he were nervous no one discovered it.

His staff was composed mostly of young South Carolinians of good family, and he had in addition a number of volunteer aids, all of them men of distinction. Ex-Governor James Chestnut was one, I think. William Porcher Miles, an accomplished scholar and elegant gentleman, I am sure was. So was that grand specimen of manhood, Colonel John S. Preston; also, Ex-Governor Manning, a most charming and agreeable companion. His juleps, made of his own dark brandy and served at mid-day in a large bucket, in lieu of something better, greatly endeared him to us all. One day all these distinguished gentlemen suddenly disappeared. Colonel Jordan simply said they had gone to Richmond; but evidently something was in the wind. What could it be? On their return, after a week's absence, as well as I remember, there was an ominous hush about the whole proceeding. Nobody had anything to say, but there was a graver, less happy atmosphere at head-quarters. Gradually it leaked out that Mr. Davis had rejected Beauregard's proposal that Johnston should suddenly join him and the two should attack McDowell unawares and unprepared. The mere refusal could not have caused so much feeling at head-quarters. There must have been aggravating circumstances, but what they were I never learned. All I could get from Colonel Jordan was a lifting of the eyebrows, and "Mr. Davis is a peculiar 


\section{AN UNRENOWNED WARRIOR}

man. He thinks he knows more than everybody else combined."

What! want of confidence in our president, at this early stage of the game? Impossible! A vague alarm filled me. I had been the first-the very first, I believe-to nominate Mr. Davis for the presidency; had violated the traditions of the oldest Southern literary journal in doing so. I had no personal knowledge of his fitness for the position. No. But his record as a soldier in Mexico, his experience as minister of war, and his fame as a statesman seemed to point him out as the man ordained by Providence to be our leader. And now so soon distrusted! I tried to dismiss the whole thing from my mind, it distressed me so. But it would not down at my bidding. Many prominent men came to look after the troops of their respective States, sometimes in an official capacity, sometimes of their own accord. Among them was Thomas L. Clingman, of North Carolina, with whom I had a slight acquaintance. How it came about I quite forget, but we took a walk, one afternoon, down the Warrenton road, and fell to talking about the subject uppermost in my thoughts-Mr. Davis. Clingman seemed to know his character thoroughly, and fortified his opinions by facts of recent date at Montgomery and Richmond. Particulars need not be given, if, indeed, I could recall them; but the upshot of it all was, that in the opinion of many wise men the choice of Jefferson Davis as President of the Confederate States was a profound, perhaps a fatal, mistake. Unable to controvert a single position taken by Clingman, 
my heart sank low, and never fully rallied, for the sufficient reason that Mr. Davis's career confirmed all that Clingman had said-all and more.

As the plot thickened, so did occurrences in and around head-quarters. Beauregard kept open house, as it were, many people dropping in to the several meals, some by invitation, others not. The fare was plain, wholesome, and abundant, rice cooked in South Carolina style being a favorite dish for breakfast as well as dinner. The new brigadiers also dropped in upon us from time to time. One of them was my old school-mate, Robert E. Rodes, a Lynchburger by birth, but now in command of Alabama troops. In him Beauregard had special confidence, giving him the front as McDowell approached. Rodes was killed in the valley in 1S64, a general of division, full of promise, a man of ability, a first-rate soldier. Lynchburg has reason to be proud of two such men as Garland and Rodes. Soldiers continued to arrive. As fast as they came they were sent toward Bull Run, that being our line of defence. Some regiments excited general admiration by their fine personal appearance, their excellent equipment and soldierly bearing. None surpassed the First Virginia Regiment in neatness or in drillin truth, few approached it. The poorest set as to size, looks, and dress were some of the South Carolinians. Louisiana sent a fine body of men. But by odds the best of our troops were the Texans. Gamer men never trod the earth. In their eyes and in their every movement they showed fight, and their career from first to last demonstrated the truth, in their case 
at least, of the old Latin adage, "Vultus index est animi" - the face tells the character. I verily believe that fifty thousand Texans such as those who came to Virginia, properly handled, could whip any army the North could muster.

But as a whole our men did not compare with the Union soldiery. They were not so large of limb, so deep in the chest, or so firm-set, and in arms and clothing the comparison was still more damaging to the South. A friend of mine, who lingered in Washington till he could linger no longer, halted a day at Manassas on his way to his old home in Culpeper County. With great pride I called his attention to Hays's magnificent Louisiana regiment, one thousand four hundred strong, drawn out full length at dress parade. He shook his head, sighed heavily, and described the stout-built, superbly equipped men he had seen pouring by thousands upon thousands down Pennsylvania Avenue. This incident made little impression on me at the time, my friend being of a despondent nature; but after my talk with Colonel Clingman it returned to me, and, I confess, depressed me not a little.

The camps were now deserted, the regiments being picketed on Bull Run. It was painful for me to go among the empty tents; it was like wandering about college in vacation-nay, worse, for it was morally certain that some, perhaps many, would return to the tents no more. I missed the faces of my friends; I longed for the lemonade "with a stick in it" that Captain Shields and Dr. Palmer used to give whenever I made them a visit, and I really pined for the red shirt 
and cheery voice of Captain H. Grey Latham, as he went from tent to tent, telling them new jokes, and on leaving, repeating his farewell formula, "Yours truly, John Dooly," which actually got to be funny by perpetual repetition and became a by-word throughout the army. Finally I got so sick of the deserted camp that I asked Clifton Smith to let me share his pallet in the little shed-room cut off from the porch at head-quarters. He kindly assented, and I moved up, but still took my meals at camp. Doleful eating it would have been but for the occasional presence of my dear friend, Lieutenant Woodville Latham, who, being judge of a courtmartial then in session, had not yet joined the Eleventh Virginia at Bull Run.

The nights were so hot that I found it almost impossible to sleep in Clifton Smith's little shed-room. My mind was excited by the approaching battle, and my habit of afternoon napping added to my sleeplessness. So the little sleep I got was in a chair on the porch. Near me, on the dinner-table, too long for any room in the house, lay young Goolsby, a lad of sixteen, who acted as night orderly. The calls upon him were so frequent and the pain of being awakened so great, that finally I said to him: "Sleep on, Goolsby, I'll take your place." He was very grateful. So I played night orderly from 12 o'clock till 6 A. M. thenceforward, and on that account slept the longer and the harder in the afternoon. Near sunset on the 18th I arose from Smith's pallet in the shed-room, washed my face, and walked out upon the porch. It was filled with officers and men, all looking toward Bull Run. One of them said: 
"That's heavier firing than any I heard during the war in Mexico."

"It was certainly very heavy," was the reply, "but it seems to be over now."

And that is all I know about the battle of the 18th. I had slept through the whole of it! Major Harrison, of our regiment, was killed; Colonel Moore, of the First Virginia Regiment, and Lieutenant James H. Lee, of the same regiment, were wounded, the latter seriously, as it turned out. There were no other casualties that particularly interested me.

Every one knew the ordeal was at hand. The movements preceding the great tragedy had the hurry and convergence which belong to all catastrophes. A confused mixture of memories is left me-things relevant and irrelevant. L. W. Spratt, Thomas H. Wynne, Mrs. Bradley T. Johnson-the big guns of the intrenched camp; the night arrival of Johnston's staff, the parting with my friend Latham-all these and many more recollections are piled up in my mind. Beauregard's plan of battle had been approved by General Johnston. Ewell was to attack McDowell's left at early dawn, flank him, and cut him off from Washington, our other brigades from left to right cooperating. Until midnight and later all of Colonel Jordan's clerks were busy copying the battle orders, which were at once sent off to the divisions and brigades by couriers. I myself made many copies. The last sentence I remember to this day; it read as follows: "In case the enemy is defeated he is to be pursued by cavalry and artillery until he is driven across the Poto- 


\section{AN UNRENOWNED WARRIOR}

mac." He needed no pursuit, but went across the Potomac all the same. No, not all the same. Had we followed in force the result might have been different. I sat up as usual that night, but recall no event of interest.

As morning dawned, I wondered and wondered why no sound of battle was heard-none except the distant roar of Long Tom, which set the enemy in motion. How Ewell failed to get his order, how our plan of battle failed in consequence, and how near we came to defeat, is known to all. 'Tis an old, and to Confederates, a sad story.

On the morning of the 18th, as Beauregard walked out to mount his horse, he stumbled and came near falling-a bad augury, which, we thought, brought a shadow over his face. But on this morning, the 21st all went well; the generals and their staffs, after an early breakfast, rode off in high spirits, victory in their very eyes. My duty was to look after the papers of the office, which had been hastily packed up, and, in case of danger, see that they were put on board a train, which was held in readiness to receive them and other valuable effects. 'The earth seemed to vomit men; they came in from all sides. Holmes, from Fredericksburg, at the head of his division, in a high-crown, very dusty beaver, I well recollect. He made me laugh. Barksdale, of Mississippi, halting his regiment to get ammunition. The militia ensconced behind the earthworks of the intrenched camp, their figures flit before me. It was a superb Sabbath day, cloudless, and at first not very hot. A sweet breeze from the west blew 
in my face as I stood on a hill overlooking the vale of Bull Run. I saw the enormous column of dust made by the enemy as they advanced upon our left. The field of battle evidently would be where the comet, then illuminating the skies, seemed to rest at night. Returning to head-quarters I reported to Colonel Jordan the movement upon our left.

"Has McDowell done that?" he asked, with animation. "Then Beauregard will give him all his old boots, for that is exactly where we want him."

The colonel meant that Ewell would have a better chance of attack by reason of the weakening of McDowell's left.

Again and again I walked out to watch the progress of the battle, which lasted a great deal longer than I expected or desired. The pictures of battles at a distance, in the English illustrated papers, give a good idea of what I saw, minus the stragglers and the wounded, who came out in increasing numbers as the day advanced, and disheartening President Davis as he rode out to the field in the afternoon. At noon or thereabout a report that our centre had been broken hurried me back to head-quarters, and although the report proved false, kept me there for several hours, the battle meanwhile raging fiercely, and not a sound from Ewell.

Restless and excited, I went into a neighboring house, occupied by a lone woman, who was in a peck of trouble about herself, her house, her everything. The bigger trouble outside filled my mind during the recital of her woes, so that I now recall none of them. 


\section{AN UNRENOWNED WARRIOR}

Unable longer to bear the suspense, I left important papers, etc., to take care of themselves, and set out for the battle-field, determined to go in and get rid of my fears and doubts by action. I reached the hill which I had so often visited in the morning, and paused awhile to look at some of our troops, who were rapidly moving from our right to our left. Just then-can I ever forget it?-there came, as it seemed, an instantaneous suppression of firing, and almost immediately a cheer went up and ran along the valley from end to end of our line. It meant victory-there was no mistaking the fact. I stood perfectly still, feeling no exultation whatever. An indescribable thankful sadness fell upon me, rooting me to the spot and plunging me into a deep reverie, which for a long time prevented me from seeing or hearing what went forward. Night had nearly fallen when I came to myself and started homeward. The road was filled with wounded men, their friends, and a few prisoners. I spoke kindly to the prisoners, and took in charge a badly wounded young man, carrying him to the hospital, from the back windows of which amputated legs and arms had already been thrown on the ground in a sickening pile.

At head-quarters there was a great crowd waiting for the generals and Mr. Davis to return. It was now quite dark. A deal of talking went on, but I observed little elation. People were worn out with excitement - too many had been killed-how many and who was yet to be learned. War is a sad business, even to the victors. I saw young George Burwell, fourteen years of age, bring in Colonel Corcoran, his personal captive. 
I heard Colonel Porcher Miles's withering retort to Congressman Ely, who tried to claim friendly acquaintance with him, but went off abashed in a linen duster with the other prisoners. I asked Colonel Preston what he thought of the day's work.

"A glorious victory, which will produce immense results," was his reply.

"When will we advance?"

"We will be in Baltimore next week."

How far wrong even the wisest are? We never entered Baltimore, and that victorious army, c ne-half of which had barely fired a shot, did not fight another pitched battle for nearly a year!

It was after midnight when I carried to the telegraph office Mr. Davis's despatch announcing the victory. Inside the intrenched camp one thousand or twelve hundred prisoners were herded, the militia standing up side by side guarding them and forming a human picket-fence, funny to behold. It was clear as a bell when I walked back; the baleful comet hung over the field of battle; all was very still; I could almost hear the beating of my tired heart, that had gone through so much that day. Too much exhausted to play orderly, I slept in my chair like a top.

The next day, Monday, the 22d, it rained, a steady, straight downpour the livelong day. Everybody flocked to head-quarters. Not one word was said about a forward movement upon Washington. We had too many generals-in-chief; we were Southerners; we didn't fancy marching in the mud and rain-we threw away a grand opportunity. For days, for weeks, you might 


\section{AN UNRENOWNED WARRIOR}

say, our friends kept coming from Alexandria, saying with wonder and impatience: "Why don't you come on? Why stay here doing nothing?" No sufficient answer, in my poor judgment, was ever given. The dead and the dying were forgotten in the general burst of congratulation. Now and then you would hear the loss of Bee and Bartow deplored, or of some individual friend it would be said: "Yes, he is gone, poor fellow"; but this was as nothing compared to the joyous hubbub over the victory. How proud and happy we were! Didn't we know that we could whip the Yankees? Hadn't we always said so? Henceforth it would be easy sailing-the war would soon be over, too soon for all the glory we felt sure of gaining. What fools!

Captain H. Grey Latham, in his red shirt, was a conspicuous figure at head-quarters. His battery had covered itself with renown; congratulations were showered upon him. I saw Captain (afterward colonel, on Lee's staff) Henry E. Peyton come over from General Beauregard's room blazing with excitement and exaltation. Yesterday he was a private-now he was a captain, promoted by Beauregard first of all because of his signal gallantry on the field. "By - ? !" he exclaimed to me, "when I die, I intend to die gloriously." Alas! Colonel Peyton, confidential clerk of the United States Senate and owner of one of the best farms in Loudoun County, is like to die in his bed as ingloriously as the rest of us.

A young Mr. Fauntleroy, desiring an interview with General Joseph E. Johnston, I offered to procure it 
for him, and pushed through the crowd to the table at which he sat. "Excuse me, General Johnston," I began. "Excuse me, sir!" he replied, in tones that sent me away in a state of demoralization.

The next thing I remember is the coming on of night, and my resuming my post as night orderly. I was seldom aroused, and slept soundly in a chair, tilted back against the wall. In the yard just in front of me were a number of tents, one of which was occupied by President Davis. The rising sun awakened me. My eyes were still half open when Mr. Davis stepped out of his tent, in full dress, having made his toilet with care. Seeing no one but a private, apparently asleep in a chair, he looked about, turned, and slowly walked to the yard fence, on the other side of which a score or more of captured cannon were parked, Long Tom being conspicuous. The president stood and looked at the cannon for ten minutes or more. Having never seen him close at hand, I went up and looked at the cannon too, but in reality I was looking at him most intently.

That was the turning-point in my life. Had I gone up to him, made myself known, told him what I had done in his behalf, and asked something in return, $\mathrm{my}$ career in life would almost certainly have been far different. We were alone. It was an auspicious time to ask favors-just after a great victory-and he was very responsive to personal appeals. My prayer would have been heard. In that event I should have become a member of his political and military family, or, what would have suited me much better, have gone to Lon- 


\section{AN UNRENOWNED WARRIOR}

don, as John R. Thompson afterward did, to pursue in the interest of the Confederacy my calling as a journalist. But Clingman's talk had done its work. Already prejudiced against Mr. Davis, his face, as I examined it that fateful morning, lacked-or seemed to-the elements that might have overcome my prejudices. There was no magnetism in it-it did not draw me. Yet his voice was sweet, musical in a high degree, and that might have drawn me had I but spoken to him. I could not force myself to open my lips, but walked back to my chair on the open porch, and my lot in life was decided.

General Beauregard removed his head-quarters to the house of Mr. Ware, some distance from Manassas Station, a commodious brick building, in which our friend, Lieutenant James K. Lee, lay wounded. Mr. Ware's family remained, but most of the house was given up to us. I slept in the garret with the soldier detailed to nurse Lieutenant Lee. In the yard were a number of tents occupied by the general and his staff. Colonel Jordan's office was in the house. My duty, hitherto light and pleasant, now became somewhat heavy and disagreeable. I had to file and forward applications for furlough, based mainly upon surgeons' certificates. This brought me in contact with many unlovely people, each anxious to have his case attended to at once. It was very worrying. Others beside myself, the clerks and staff officers, seemed to be as much worried by their labors as I was by mine. Fact is, young Southern gentlemen, used to having their own way, found it hard to be at the beck 


\section{AN UNRENOWNED WARRIOR}

and call of anybody. The excitement of battle over, the detail of business was pure drudgery. We detested it.

The long, hot days of August dragged themselves away. No advance, no sign of it; the men in camp playing cards, the officers horse-racing. This disheartened me more than all things else, but I kept my thoughts to myself. At night I would walk out in the garden and brood over the possible result of this slow way of making war. The garden looked toward the battle-field. At times I thought I detected the odor of the carcasses, lightly buried there; at others I fancied I heard weird and doleful cries borne on the night wind. I grew melancholy.

Twice or thrice a day I went in to see Lieutenant Lee. Bright and hopeful of recovery, he gave his friends a cheery welcome and an invitation to share the abundant good things with which his mother and sisters kept him supplied. A visit to his sick chamber was literally a treat. The chances seemed all in his favor for two weeks or more after our arrival at the Ware house, but then there came a change for the worse, and soon the symptoms were such that his kinsman, Peachy R. Grattan, reporter of the court of appeals, was sent for. He rallied a little, but we saw the end was nigh. Mr. Grattan promised to send for me during the night in case anything happened, and at two o'clock I was called. The long respiration preceding death had set in. Mr. Grattan, kneeling at the bedside, was praying aloud. The prayer ended, he celled the dying officer by name. "James" (louder), 
"James, is there anything you wish done?" Lieutenant Lee murmured an inarticulate response, made an apparent effort to remove the ring from the finger of his left hand, and sank back into the last slumber. I waited an hour in silence; still the long-drawn breathing kept up.

"No need to wait longer," said Mr. Grattan; "he will not rouse any more."

I went to my pallet in the garret, but could not sleep; at dawn I was down again. The long breathing continued; Mr. Grattan sat close to the head of the bed and I stood at the foot, my gaze fixed on the dying man's face. Suddenly both his eyes opened wide; there was no "speculation" in them, but the whole room seemed flooded with their preternatural light. Just then the sun rose, and his eyes closed in everlasting darkness, to open, I doubt not, in everlasting day. So passed away the spirit of James K. Lee.

A furlough was given me to accompany the remains to Richmond, with indefinite leave of absence, there being no sign of active hostilities. In view of my infirm health a discharge was granted me after my arrival in Richmond, and thus ended the record of an unrenowned warrior.

Let me say a word or two in conclusion. In 1861 I was thirty-three years old; now I am fifty-five, gray and aged beyond my years by many afflictions. I wanted to see a great war, saw it, and pray God I may never see another. I recall what General Duff Green, an ardent Southerner, said in Washington, in the win- 


\section{AN UNRENOWNED WARRIOR}

ter of 1861, to some hot-heads: "Anything, anything but war." So said William C. Rives to some young men in Richmond just after the fall of Sumter: "Young gentlemen, you are eager for war-you little know what it is you are so anxious to see." Those old men were right. War is simply horrible. The filth, the disease, the privation, the suffering, the mutilation, and, above all, the debasement of public and private morals, leave to war scarcely a redeeming feature. 


\section{JOHN M. DANIEL'S LATCH-KEY*}

\section{A MEMOIR OF THE EDITOR OF THE RICHMOND "EXAMINER"}

OME days ago I found, in an old drawer, the latch-
key which the editor of the Richmond Examiner gave me in 1863. It fitted the door of the house on Broad Street, opposite the African church-the house in which he died. A bit of brass, differing in nothing from others of its kind, this key, nevertheless, has its charm. It is the only souvenir I have of one of the most remarkable men Virginia ever produced. Coming upon it unexpectedly, after I had given it up as lost, the bare sight of it crowded my mind, in an instant, with pictures of its former owner. I saw him in Washington, just after his return from Europe, con-

* In December, 1867, soon after the publication of the "LatchLey" in the Native Virginian, I visited the eity of Richmond, and, while there, was convinced that I had made, unwittingly, two decided errors: First, John M. Daniel did not write "The Parliament of Beasts." The real author is known, but his name is withheld for sufficient reasons. Second, the walk to Petersburg was made, not for the purpose of lending, but of paying money which the editor of the Examiner had collected for his friend, the then artist Peticolas. This I learned from the diary which Daniel kept at that time, and which Mr. T. H. Wynne has now in his possession. In respect of other matters of fact, I believe the memoir is substantially correct. 


\section{JOHN M. DANIEL'S LATCH-KEY}

versing with Seddon and Garnett; in his own room over the Examiner office, as he sat lordlike, in a high arm-chair, in August, 1861, questioning me about the battle of Manassas and exhibiting the major's uniform which he intended to wear as aid to General Floyd; in the editorial room, cutting and slashing leaders which had been written for him, or denouncing fiercely the administration; at his dinner-table, pledging Wigfall and Hughtes in a glass of old Madeira; in the bed, where he lay wounded, after the duel with Elmore; and last of all, I saw his marble face-how changed!as he lay in his metallic coffin, March 31, 1865.

All these likenesses of this strange man came vividly before me as I looked at the key of his door, and with them came a host of recollections, some of which I am now about to set down. Not that I have anything to tell which others could not tell as well, or better than myself. For it must not be inferred, because he gave me the privilege of entering his house at any hour of the day or night that pleased me, that I was the intimate personal friend of John M. Daniel. No; he took a short-lived fancy to me, and gave me his latchkey; that is all. While the fancy lasted I used the key but seldom, and after it died out, not at all. Doubtless he soon forgot that he had ever given it to me. My aim is simply to put down, in chronological order, a number of incidents and sayings illustrative of the character of one who, in some respects, resembled John Randolph, of Roanoke, and who, like Randolph, was of a nature so peculiar that the most trivial reminiscences can hardly fail to prove interesting to hundreds 
of thousands in the South, and to not a few in the North.

My acquaintance with him began in Washington, after his return from Turin. He registered his name at Brown's Hotel, in a small hand, simply as "Mr. Daniel, Liverpool." Although I had never seen a scrap of his writing, I knew, the moment I saw his name on the register, that the man for whom so many were anxiously looking, had arrived. The next evening I was introduced to him. I had long been curious to see "the great editor," and availing myself of his animated conversation with other visitors, eyed him intently, seeking in the outward man some indication of the extraordinary being within. My search was not in vain. The poorest physiognomist could not have seen Daniel's face, even for a moment, without being attracted-I am tempted to say fascinated -by it. True, we always find what we are taught to expect in a face, and often discover what does not exist; but here was a countenance singularly marked -a dark, refined, decidedly Jewish face. The nose was not very large, and but slightly aquiline; the mouth thin-lipped, wide, unpleasing, and overhung by a heavy black mustache; the chin square, but not prominent; the cheeks thin; and both cheeks and chin covered by a dense, coarse, jet-black, closely trimmed beard; eyebrows very thick and black, shading deep-set, rather small hazel eyes; head as small as Byron's or Brougham's, beautifully shaped and surmounted by masses of hair, which in youth hung long and lank and black to his coat collar, but in later life 
was worn close-cut. Such was John M. Daniel, as he sat before me in a room at Brown's Hotel, in the memorable winter of 1861 .

$\mathrm{He}$ was richly but plainly dressed. He talked freely upon the topics then uppermost in every Southern mind, but there was a hesitation, or rather a tripping, amounting almost to a stammer, in his speechthe result, probably, of his long residence abroad and the constant use, in conversation, of French or Italian instead of the English language. This tripping had entirely disappeared when I met him, a few months later, in Richmond. It was not an affectation, as I had at first supposed.

During a number of interviews which I had with him in Washington, he was always courteous, good-natured and talkative. His moroseness, his bitterness, of which I had heard so much, seemed to have been dissipated by the genial climate of Italy and the polite atmosphere of courts. One night, however, Floyd's name being mentioned in connection with the affair of the Indian Trust Bonds, some reckless person took it upon himself to say that in the public opinion the then Secretary of War was "no better than a thief." Daniel flamed instantly. He rose from his chair with a white face and with trembling lips, and denounced the charge against Governor Floyd as an accursed slander. In proof that Floyd had not appropriated to his own use one cent of the public funds, he stated a fact, not to be mentioned here, which seemed to carry conviction to all who heard it. He was very much agitated; his passionate nature so overmastered him that he could 


\section{JOHN M. DANIEL'S LATCH-KEY}

not, although he tried to, resume his calmness, and the party soon dispersed from the room.

During his stay in Washington, which lasted two or three weeks, I met him but once after this exciting scene. He was then in Mr. Seddon's room, conversing with that distinguished member of the Peace Congress, and with the Hon. M. R. H. Garnett. Late English publications, relating to Continental and British politics, were under discussion, and Daniel showed himself perfectly familiar with every book or pamphlet which the other gentleman had read. Little was said so long as I was present about Federal politics. It cannot, however, be doubted that the Virginia editor was in the intimate counsels of the leaders of the Southern movement, and that, while he gave them the benefit of his eminently clear intellect, he in turn was enabled by their information and opinions to post himself thoroughly on all those points which were shortly to be brought before the public in the columns of the improved and, for the first time, Daily Examiner.

The potent influence of this paper, from the moment that Daniel resumed the helm, was felt not only in Virginia, but throughout the entire South. To this day, the effect of a single article, which appeared a few weeks after the Examiner began to be issued daily, is remembered by almost every man, woman, and child in Virginia. I allude, of course, to "The Parliament of Beasts," in which the members of the Virginia Convention, then in session, were likened to dogs, cats, owls, opossums, and other members of the animal kingdom. The likenesses were so happily and so 


\section{JOHN M. DANIEL'S LATCH-KEY}

trenehantly drawn that it was impossible to mistake them, and many hundreds, if not thousands, of copies of the issue containing the article were sold in a few hours. Some offence was given, but so much humor, and wit so genuine were mingled with the satire, that the Union men, who were most offended, were obliged to join in the laugh at their own carieatures. "Who is the author?" was in everybody's mouth. This question was never satisfactorily answered. The article appeared as a contribution, but in editorial type, and the great majority of people suspected that Daniel himself was the author. This, however, was denied, and many conjeetures were made as to the man, in or out of Virginia, who was capable of doing so clever a thing. Two years or more after its appearance, while sitting alone with Daniel, I asked him to tell me in confidence who the real author was. He was pacing the floor of his sanctum, as was his wont. He stopped abruptly, put his hands in his poekets, turned his face toward me, and said, with the utmost gravity:

"No one knows better than yourself who wrote that article."

"Nonsense," I replied; "I really want to know. Tell me. I pledge you my word that I will never reveal the secret until you give me permission to do so."

He looked keenly at me, as if to ascertain whether I could be trusted, and for a moment I felt sure that he was going to tell me; but turning suddenly on his heel, he began again to pace the floor in silence. He refused to tell me even the author of the paraphrase in verse, which appeared some time after the original. I have 
scarcely a doubt but that he himself wrote the original in prose, and I think I can make a very good guess as to the authorship of the poetic version. The latter I attribute to the same hand which penned "Fie! Memminger," and similar articles in rhyme, which were printed in the Examiner during the years 1864-5.

In May, 1861, I went to Manassas with the first battalion sent thither from Richmond. No sooner was I upon the ground than I felt, as by prescience, rather than by any comprehension of the strategic value of the position, that the place was to be the scene of a great battle; and shortly afterward, with the aid of my friend, Lieutenant $\mathrm{L}-$, embodied my views and apprehensions in an article of considerable length, which I sent to the Examiner-no order to the contrary having then been issued. Daniel thought it imprudent to publish the article, but was so pleased with it that he continued to send me, as long as I remained at Manassas, five copies of his daily paper. He also offered me my own price for any letters I might choose to write him. Even had it been lawful, I could not have accepted his proposition, for the reason that the fatigues of incessant drilling left me little inclination and less ability to write even to my own father. But the prompt recognition of the little service I had rendered him-a promptness which, as I afterward discovered, was characteristic of Daniel-and doubtless a good deal of gratified vanity at the estimate he had placed on my contribution, impelled me to call on him as soon as I reached Richmond, in August, after the great battle. 


\section{JOHN M. DANIEL'S LATCH-KEY}

He was then living in two rooms, handsomely fitted up, in the second story of the Examiner building. The front room he used as a bedchamber, the back room as a sanctum and a hall of audience for his many visitors. In the latter were a number of easy chairs; and one in particular, which he preferred above all the rest. It was a sort of barber's chair, covered with horsehair, and elevated much more than ordinary chairs above the floor. From this seat, as from a throne, he looked down upon and conversed with his visitors; and to me at least (I know not how it was with others) his words descended from their elevation with a certain authority, as from a true cathedra.

The day was warm, and the editorial pontiff was by no means in his robes of office. He wore neither coat nor vest, only a pair of white duck pantaloons. He looked spotlessly clean, cool, and comfortable. His reception was kind, almost to cordiality. He talked freely about the war, about the generals, and the plans of campaign, but was very guarded in his comments upon the administration, which, up to this time, he had heartily supported. Indeed, the Examiner was, for many months after the war began, regarded as the organ of the administration. Full of his expected campaign with Floyd, he told me, with an air of satisfaction, how he intended to be comfortable and to escape the filth and misery of camp life. He was going en grand tenue-with a chest stored with the good things of this life, a tent of his own fashioning, a complete cooking apparatus, his own cook and his own valet. 
I asked him if he had no fear of being killed or wounded. He replicd that he did not think he would be killed, and that the chances were that he would not be wounded. "I hate pain," said he; "I cannot bear it, and yet I, should like to be able to show an honorable scar in this cause." His campaign in south-western Virginia was not of long duration. I am satisfied, from what he afterward told me, that he joined General Floyd, not for a holiday, but with the purpose of winning military glory. He was ambitious in everything he undertook, and on more than one occasion he expressed to me a great regret at having left the army. "By this time" (the winter of 1864), said he, "I might have been a brigadier-perhaps a major-general."

"But," said I, "as the editor of the Examiner, you are exerting an influence far greater than any brigadier -greater, perhaps, than any major-general."

"True," he answered; "but what good is the Examiner, or any other paper, or all the papers in the Confederacy combined, doing? Besides, I like to command men. I love power."

After the interview in August, 1861, I saw very little of him for two years. I met him occasionally on the street, but his manner was so repelling that I was deterred from gratifying the desire, which I often felt, of going to see him. With his old habits had come back his old ways-he was as cold, self-contained and gloomy as he had been before he went to Europe. Affairs were not going in the fashion that suited him. Grave doubts were beginning to arise in his mind. He still had hopes, and often high hopes, of the success of 


\section{JOHN M. DANIEL'S LATCH-KEY}

the cause, but the course of the administration excited continually the bitterness of his nature. Then, again, the whole weight of the Examiner, which he frequently described to me "as a mill-stone about his neck," was upon him. Convinced that his editorial labors were well nigh useless, in so far as they influenced the conduct of the war, the finances, or anything else pertaining to the policy of Mr. Davis, it was but natural that his mental energies should flag and his wonderful powers of composition should be abated. He was anxious to get an assistant, but could find no one to suit him. He had fallen out with one whose brilliant and humorous pen had served him so well in former years. Edward A. Pollard was in ill health, and had started, or was about to start, for Europe, and he had not succeeded in getting the two or three writers, whose contributions, a few months later, added so greatly to the value and the interest of the Examiner.

It was at this time, in the summer of 1863 , while on a visit to the country, that I amused myself one evening by writing a satirical article on the then exciting subject of the removal of the quartermaster-general. This I sent to Daniel. What was my surprise by return mail, to receive from R. F. Walker, the manager of the Examiner, a flattering letter, telling me of Daniel's high appreciation of my article, and his desire to secure my services as assistant editor. An engagement on another paper prevented me from accepting the proffered situation; moreover I knew well that Daniel was a "hard master." Nevertheless, I was anxious to see in print an article which had reccived the approval of 


\section{JOHN M. DANIEL'S LATCH-KEY}

such a critic as John M. Daniel. I looked each day, but never saw it. I own that I felt chagrined. My only conclusion was that Daniel, at a first reading, had overestimated the merits of the article, and that a subsequent perusal, revealing faults which he had not before detected, had determined him not to publish it.

On my return to Richmond, I felt little desire to meet any of the Examiner people; but passing Walker one day on the street, he hailed me and told me to come to the office; he had some money for me.

“Money for what?" I inquired.

"For that article you sent down. Don't you remember it?"

"I remember it distinctly, but I also remember that you never printed it."

Walker was positive that the article had been printed, and I no less positive that it had not. Finally he referred me to Mr. Daniel, and to him, accordingly, I went. He received me kindly, complimented my article extravagantly, as I thought, and asked me if Walker had paid me for it. I was a good deal nettled, supposing that he was making fun of me. I told him in reply, that Walker had offered to pay me much more than the article was worth, according to the established rates of the Examiner (which I knew), but that I had refused payment on the ground that the article had never appeared. His eye twinkled mischievously, as he said:

“You didn't see it, because you didn't read the Examiner. The Examiner contains the best thoughts of the best minds in the Confederacy, expressed in the 176 


\section{JOHN M. DANIEL'S LATCH-KEY}

best manner-it is the organ of the thinking gentlemen of the country. You ought by all means to read it. There is the file; look at the number for —-, and you will find your article."

I looked, and sure enough, there was an article twice as long and twice as good as the one I had writtenmy own ideas, but so enveloped in Daniel's fine English, and so amplified that it was hard to recognize them.

I have purposely related this incident at some length, because it illustrates Daniel's character and unfolds one of the secrets of his great success as an editor. He begrudged no labor in elaborating and improving an article which pleased him. I remember his telling me that he had written a certain article over four or five times. The original draft was sent to him by a lady distinguished for her attainments and performances in literature. It was a defence of his favorite general. He was gallant to a degree and the warmest of partisans; and both his gallantry and his friendship being aroused, he exerted himself to the utmost to make the article as printed a telling one. If I am not mistaken, I have this identical article now in my possession. It is headed, Ohe! jam satis.

Although I would not accept the place of assistant, and could by no means have filled it to his satisfaction if I had, I was glad enough, in order to eke out my narrow living, to enter into an engagement to furnish him with two or three editorials a week-an engagement which lasted for several months. It was at this time that he gave me his latch-key and I became somewhat intimate with him. I made many visits to him 
at his house on Broad Street; and had many talks with him on all sorts of subjects. He was not a secretive man; on the contrary, he conversed with the utmost freedom about himself, his early life, his residence abroad, his relatives and friends, his political associates and opponents, indeed almost everything. Unless he happened to be out of humor (which was not of ten the case at his private residence), he loved to talk; and though a recluse, he was delighted with the visits of gentlemen who came without solicitation on his part and who called in a friendly and social way. He urged me to visit him at night, and in order to tempt me to repeat my visits would give me each time what was then a great and costly treat, a bottle of English ale. This he repeated several times, but finding that I did not play chess and was a much better listener than talker, in fact, that I could not talk well enough to provoke him to talk, he soon became tired of my visits-a fact of which he gave me convincing proof by yawning in my face!

This house on Broad Street and his mode of living deserve notice. The house was of brick, three stories high, commodious and comfortable. It was one of a number of investments in real estate which he made during the war. Although no human being but himself inhabited this house- the servants being restricted to the kitchen of four rooms in the back yard-he lived, literally, all over it. The front room on the first floor was his parlor. In it were two large oil paintings, works of decided merit, a mosaic chess table and a few mahogany chairs. Sometimes he received his 178 


\section{JOHN M. DANIEL'S LATCH-KEY}

visitors in the parlor, but more often in the diningroom adjoining, where he kept a table for writing and his iron safe. A handsome sideboard and a set of solid dining tables of antique pattern graced this apartment. He was fond of telling that these tables once belonged to "old Memminger," and were bought when the worthy Secretary of the Treasury broke up housekeeping on Church Hill. The front room in the second story was his chamber, and the passage-room adjoining, his dressing closet. A tall mirror, which reached from the floor almost to the ceiling, was fastened to the wall between the two front windows. Hard by was a large cheval glass, by means of which he was enabled to see his whole figure, front and rear, from head to foot. He was not a fop, but he was fond of dress, and had an eye to appearance, not only in person, but in print. He had a horror of slovenliness. A carelessly written editorial was his abomination. He used to say that a man who goes into print ought to remember that he is making his appearance before the very best society, and that he owes it both to himself and to that society not to appear in undress. When an acquaintance of the writer of this article was married in clurch, one February afternoon in 1863, John M. Daniel was there in a long-tail coat and white waistcoat. He believed in white waistcoats. He told his manager, Walker, that he ought never to go to a party without wearing a white vest.

“But, Mr. Daniel," objected Walker, “suppose a man hasn't got a white vest and is too poor, these war times, to buy one?" 
"D—n it! sir, let him stay at home."

Besides the mirror, the cheval glass and a few chairs, there was no other furniture in his chamber, except an old-fashioned high-post bedstead, which, together with most of his furniture, he had bought at the sales of the refugees once wealthy. He believed in blood, in families of ancient and honorable descent, in gentlemen, and preferred the workmanship and antiquated style of things which had descended as heirlooms in the houses of gentlemen to the costliest and most tasteful productions of modern cabinet-makers. There was no carpet on the floor of his chamber, and he slept without a fire. In the morning a fire was built in the room next to his chamber, and there his breakfast was generally served between eleven and twelve o'clock. He seldom went to bed before two or three o'clock in the morning. This back room in the second story had a bed in it and was used as a guest chamber, but I do not remember to have known or heard of but one occupant-R. W. Hughes. He made Daniel's house his home whenever he came to town.

Adjoining the dressing-room, in the passage of the second floor, was the bath room. Leaning against the door of this bath room I used to see a bag of Java coffee, which made my mouth water every time I looked at it, for coffee, in those days, was twenty to thirty dollars a pound.

The first room in the third story was used as a sort of lumber room. A barrel or two of white sugar, a few boxes of manufactured tobacco, and some large empty boxes, which had contained books, were there 


\section{JOHN M. DANIEL'S LATCH-KEY}

the last time I looked in. The little room, cut off from the passage, was the library. The number of books was not what one would have expected. A complete set of Voltaire's works; the Delphin edition of the classics, complete; Swift's Works, Clarendon's Rebellion, and a few miscellaneous books are all that I can now recall. Most, if not all, of these editions were old and rare; and strange to tell, most of them were bought at private sale or at auction during the war. Daniel was an omnivorous reader, but had a sovereign contempt for the so-called "literature of the day." The first Napoleon, riding post in his carriage to the theatre of war, amused himself by dipping into books just published and pitching one after another out of the window. This was much the way with John M. Daniel, before he went abroad, when, in his capacity as editor of the Examiner, all the new publications were sent to him. He never cared to keep them - -ither gave or threw them away, and if he had occasion to make an extract from one of them, used his scissors remorselessly.

The back room, in the third story, was a favorite one with him. Like all the other rooms, it was tastefully and cheerfully papered. It commanded a view of James River, the Hills of Henrico, and the wide lowlands and woods of Chesterfield. Having a southern exposure, there was always plenty of light in the afternoon, and the room was easily made warm and comfortable. Here he loved to sit in a leather-bottomed chair, with a little table near him, reading Voltaire, the Latin poets, or contributions and communications 
to the Examiner. In this room he kept his collection of medals and seals; a violin lay in its wooden case on the floor, stringless and unused. A moody man, he sometimes deserted this pleasant room and confined himself for weeks to the rooms on the lower floors.

He lived well, but not luxuriously. He detested hotels and boarding-houses. When he lived in rooms over his office, he had his meals sent to him by Tom Griffin or Zetelle. After he went to housekeeping, his negro cook was his caterer. The day I dined at his house with Wigfall and Hughes, he had but one course, a single joint of meat, a few vegetables, no desert, coffee, and wine-Madeira from Governor Floyd's cellar, which Hughes had brought with him. That evening he called for "another bottle," after the rest were satisfied; but I never saw him intoxicated, and on one occasion only under the influence of wine even in a slight degree. Then his eyes were a little glassy, his manner dogmatic, and he rocked a little as he stood up in front of me and laid down the law in regard to things political. Whiskey he hated with his whole heart. I have heard him curse it and its effects most bitterly, and once wrote, at his special request, an article beginning, "Whiskey, not the Yankee, is to be the master of the Confederacy." The feebleness of his digestion compelled him to be temperate both in eating and drinking. I have heard him say that a single glass of whiskey and water taken at night, by prescription of his physician, would give him headache the next day.

Coffee was his favorite stimulant, but I do not think 182 


\section{JOHN M. DANIEL'S LATCH-KEY}

he used it to excess. He was so fond of it that he would not rest until he had taught his pet terriers to drink it. These dogs- "Frank" and "Fanny" were their names, I believe-he loved, but in his own fashion. He delighted in teasing and worrying them; would pinch and pull their ears until they yelped with pain, and was never more pleased than when he succeeded in getting up a mild fight between them. This was not easy to do, because "Fanny" was "Frank's" mother; and, when he was set upon her, went to work with rather a bad grace, while she bore his attacks with exemplary patience. When Daniel got tired of playing with his pets, who were devoted to him, he would drive them away with his horsewhip. Yet he never laid on with the full weight of his hand. He was cruel to them at times, but never brutal.

I asked him one day if his solitary mode of life did not make him suffer from ennui. "Yes," said he, wearily, "but I am used to it."

"Don't you find solitary feeding injurious to your health? I tried it once at college, and, within a week, I was made positively sick by it."

"You are right," he replied. "It literally destroys the appetite. In Turin, I employed an Italian count as my chef de cuisine. He was really an artist in his profession, and exerted all his powers to please me. He had carte blanche as to expense, and sent me up every day the most tempting dishes. I could taste them-that was all. I never enjoyed a meal at home. Whereas, when invited to dine in the country with a pleasant party of ladies and gentlemen-would you 
believe it?-I would sometimes be helped three times to meat."

I asked him then, as I had often done before, why he did not marry. He was always pleased when the subject was broached, and I am sure we must have had, first and last, a dozen conversations on this topic alone. After discussing the pros and cons, he generally wound up by declaring that, if he ever married, it must be with the explicit understanding that himself and his wife should occupy separate houses. To this end, he often threatened to buy the house next to his own and have a door cut in the partition wall, the key of which he would keep in his own pocket. "The noise of children and the gabble of a woman with her lady friends was something which he could not and would not stand."

He was a warm admirer of the female sex, but his opinion of them was not the most exalted. Social life on the Continent did not tend to weaken his natural prejudice against mankind, and probably lessened his esteem for the fairer portion of humanity. Over the mantle-shelf in his chamber hung an exquisite miniature on ivory. The face was, beyond question, the most beautiful I have ever seen, and the execution was worthy of the subject. This picture was presented to him by the lady who painted it, and it was her own likcness. According to his account, she was titled, rich, marvellously accomplished in music, painting and poetry, eccentric, reckless alike of herself and of others. Her name he would never tell me. He confessed to other fancies while in Europe, but did not acknowl184 
edge, and I believe did not have, a serious affair during the whole seven years of his residence abroad. It is said that his heart was never touched but once, and then by a beautiful Virginian. This was before he left America. He told me frequently that it was impossible for him to love a girl who was not pretty, and yet he would shudder at the thought of uniting himself to a "pretty fool." It was to no purpose that I insisted that true beauty was of the soul alone. He hooted at this doctrine as "a stale lie." Beauty of face he might possibly dispense with, but beauty of form-beauty of some sort-a graceful figure and highbred manner were absolutely essential. Happening, one evening, to express in his hearing my regret that I was not acquainted with some young lady in Richmond who played well on the piano, he started almost as if I had stabbed him, and gave vent to an exclamation of the most intense disgust-as if the bare idea of a pianoplaying young lady nauseated him. His theory about the management of women was simple and original. "There are," he would say, "but two ways to manage a woman-to club her or to freeze her."

His menage in 1863-4 consisted of three servants, all males-a cook, an hostler, and a valet, who also acted as his dining-room servant. His manner toward the boy who waited in the house was rough even to harshness. He liked his hostler, and spoke kindly to him, whenever I happened to see them together. I do not wonder that his house servants ran away from him. He lost two within as many years. One was caught, punished and immediately sold. The other, for whom 
he offered a reward of $\$ 2,000$, made good his escape. After that, he bought a very likely woman, nearly white, who remained with him until his death.

Such was John M. Daniel at home. What he was at his office, I will now proceed to tell. Whilst I was contributing to his paper, my habit was to hand my article to the manager in the morning, and at night I would go around to read the proof. Daniel himself always read the proofs, though not with as much pains as I liked. He reached the office generally between eight and nine o'clock, and I was almost always there before him. In those days garroters were abundant, and the first thing he did, after entering the room, was to lay a Derringer pistol, which he carried in his hand ready for any emergency, on the large table which sat in the middle of the floor. This done, he would offer me a cigar-he could never be persuaded to smoke a pipe, and his cigars were of the weakest-and then begin the work of examining proofs. First, the proofs of the news columns, then of legislative or congressional proceedings, next the local news, and lastly the editorials. All these he examined with care, altering, erasing, abridging and adding as he thought fit. Even the advertisements were submitted to him, and I have known him to become furious over an advertisement which he thought ought not to have been admitted.

He was the only newspaper proprietor I ever heard of who would throw out, without hesitation, paying advertisements, sometimes of much importance to advertisers, in order to make room for editorials, or for contributions which particularly pleased him. Often- 
times his news column was reduced to the last point of compression to make room for editorial matter. The make-up of his paper engaged his serious attention, and I have known him to devote nearly half an hour to the discussion of the question where such and such an article should go, and whether it should be printed in "bourgeois," "brevier," or "leaded minion." He loved to have two or three really good editorials in each issue of his paper. Short, pointed articles he had little faith in, believing that the length of a column, or a column-and-a-half, was essential to the effect of an article. The London Times was his model, and he promised himself, in case the Confederate cause succeeded, to make the Examiner fully equal to its English model. A pungent paragraph was relished by him as much as by any human being-indeed, he was quick to detect excellence in anything, long or short-but the sub-editorial, or "leaded minion" column, was left apart for just such paragraphs, and the dignity of the editorial column was but once, within my recollection, trenched upon. Even then the article was a short editorial rather than a paragraph. It was near the close of the war, when, despairing of the cause, he urged, in a few strong sentences, the duty of Virginia to hold herself in readiness to resume her sovereignty, and to act for herself alone in the great emergency which he felt was approaching. I am inclined to think this was the last article he ever penned.

Laying so much stress upon editorials, it was but natural that he should pay particular attention to correcting them. This, in fact, was his main business in 


\section{JOHN M. DANIEL'S LATCH-KEY}

coming to his office at night. At times he preferred to do his own writing, but in general, and certainly in the last year or two of his life, he much preferred to have his ideas put into words by others. Then he would alter and amend to suit his fastidious taste. Any fault of grammar or construction, any inelegance, he detected immediately. He improved by erasure as much, or more, than by addition; but when a thought in the contributed article was at all suggestive, he seldom failed to add two or three, and sometimes ten, and even twenty lines to it. This was a labor of love to him, and did not fatigue him as it does most people. On the other hand, he disliked extremely to read manuscript. This sometimes brought trouble upon him. Coming in one night he found on the table the proof of an article on finance which I had written. He read it over carefully, and, to my surprise, did not put his pencil through a single line of it. Whilst I was pluming myself on this unusual circumstance, he looked up at me and laughed.

"Very well written," said he, "but diametrically opposed to the views of the Examiner."

Too old a hand at the bellows to be disgruntled by this, I replied quietly:

"Pitch it in the fire."

"What! and fill two columns myself between this and midnight? This is every line of editorial on hand."

"I am really very sorry. But what is to be done? It is impossible for me to write any more. I never can write after dinner; besides, I am broken down."

"Let me see. Let me see." 
He took up the unlucky editorial, read it over more carefully than before, and then said, in a tone of great satisfaction: "I can fix it."

And so he did. Sitting down at the table, he went to work, and within twenty minutes transformed it completely. It appeared the next morning. There were certain awkwardnesses, which we two, who were in the secret, could detect, but which to the bulk of the readers of the paper were doubtless quite imperceptible.

When he had to write an article himself, his first question, after the usual salutation, was, not "What is the news?" but "What are people talking about?" and he upbraided me continually for not doing what he himself never did, "circulating among the people." He aimed always to make his paper interesting by the discussion of subjects which were uppermost in the popular mind; nor did it concern him much what the subject might be. His only concern was that it should be treated in the Examiner with dignity and ability, if it admitted of such treatment; if not to dispose of it humorously or wittily. But the humor or wit must be done cleverly and with due attention to style. He began to write about ten o'clock; wrote rapidly, in a crumpled, ugly hand, and completed his work, revision of proofs, and everything by midnight, or a little thereafter. He then returned to his house, and either sat up or laid awake in bed, reading, until two or three o'clock in the morning.

His assistants in 1863-64, besides reporters, were the local editor, J. Marshall Hanna; the news editor, H. Rives Pollard; and the editor of the "leaded min- 
ion” or war column, P. H. Gibson. He had a high opinion of them all. Pollard he declared was "the best news editor in the whole South." Hanna he pronounced "a genius in his way," and took great credit to himself for having discovered, developed, and fostered him. Gibson's ability he acknowledged and complimented frequently in my hearing.

The business of the office gave him very little trouble. He had, of course, an eye to everything; but the printing floor, the press-room, the sale and distribution of papers, mailing, the payment of employees, the settlement of bills, in a word, the finance, outdoor transactions, and banking business, were all attended to by $\mathrm{R}$. F. Walker, the manager. He had but a single bookkeeper, a gentleman of the name of Cary, who was also his cashier. Walker was his faithful assistant in everything, from the purchasing of type, and glue for rollers, to correspondence with men of business, and oftentimes with politicians and contributors. At the end of every week Walker brought to the house, on Broad Street, the bank book, posted up to date. I was permitted several times to look at this book. The net receipts per week, in $1863-4$, were from $\$ 1,000$ to $\$ 1,200$ or $\$ 1,500$. After deducting personal expenses of every kind (and Daniel never stinted himself in anything), it may be safely assumed that in the third year of the war the paper cleared at least $\$ 50,000$, perhaps double that amount. The owner was often on the lookout for investments, and made a number of purchases of real estate. He may have speculated, but if he did, the speculations must have been on a small 


\section{JOHN M. DANIEL'S LATCH-KEY}

scale. During my visits to his house I never saw there any one of the men who were known in Richmond to be largely in speculation. Moreover, his paper, in common with others, contained denunciation after denunciation of speculators of all sorts, and was particularly severe upon brokers, gamblers, and whiskey sellers. Toward the close of the war, when investments of all sorts were doubtful, I suggested to him that he had better buy gold. His reply was, "I have more gold now than I know what to do with." I am persuaded, however, that this gold was part of the $\$ 30,000$ in coin, or its equivalent, which he brought over with him from Sardinia.

I have said that he never stinted himself, and this is true. His table, indeed, was never loaded with luxuries and delicacies - which might have been bought at almost any period of the war, if one chose to pay the enormous prices asked for them-for the reason that his digestion would not tolerate anything but the simplest food; but his self-indulgence was notably shown in articles of dress, in coal, and in gas. He brought with him from Europe clothes enough to have lasted him years, but he never scrupled to buy a thousand-dollar suit whenever he fancied he needed it. When coal was very high, and one fire would have sufficed him, he kept two or three burning. Gas was costly in the extreme; two burners of his chandelier would have afforded him ample light-for he had excellent eyes-but he was not content until he had all six of the burners at their full height. In reply to my remonstrance against this extravagance, he would say curtly: 


\section{JOHN M. DANIEL'S LATCH-KEY}

"I like plenty of light."

If at his house Daniel was affable and almost genial, in his office he was, too frequently, on the other extreme. He loved to show his authority, and, as the saying is, "to make things stand around." His scowl at being interrupted, while in the act of composing, or when otherwise busily engaged, will never be forgotten by any one who ever encountered it. Holding drunken men in special detestation, he was, as by a fatality, subjected continually to their visits, both at his office and at his house. More than once I have been sufficiently diverted by intoxicated officers, just from the army, who called in to pay, in person, their maudlin tribute of admiration to the editor of the Examiner. Sometimes he bore these visitations with a patience that surprised me; but he never failed to remunerate himself by awful imprecations upon the intruder as soon as he was out of hearing. While his tone to his employees was, as a general rule, cold, and often intolerably dictatorial, I have seen him, very frequently, as affable and familiar as heart could wish. Indeed, I have known him to go so far as to come out of his sanctum into the small room occupied by his sub-editors with the proof of a contribution in his hand, in order that they might enjoy it with him. Occurrences of this sort, however, were rare.

Belonging essentially to the genus irritabile, his anger was easily provoked. He could not bear to be crossed in anything. Whoever said aught in print against "the Examiner newspaper," was sure to bring down upon himself a torrent of abuse. Possessing in an 
eminent degree, and, indeed, priding himself upon his sense of the becoming and the decorous, he was no sooner engaged in a newspaper controversy than he forgot, or at least threw behind him, the sense even of decency, and heaped upon his adversary epithets which ought never to have defiled the columns of a respectable journal. This was kept up, sometimes, long after the original heat of the controversy had abated-his purpose being, as I suppose, to give the opposing paper, and others, a lesson which would never be forgotten, and thus to ensure himself against similar annoyances in the future. To avoid trouble and to maintain the Times-like character of the Examiner, his rule was never to notice the opinions of other papers, and not even to quote from them. He waited to be attacked; ' but when attacked, he followed the advice of Polonius to the very letter. But his hottest anger and his bitterest maledictions were reserved for his political enemies. His rage against the administration of Mr. Davis, and particularly certain members of his cabinet, was, at times, terrible. In like manner, the journalistic partizans of the administration came in for a full share of his fury. I shall never forget his excitement, one night, on hearing that a certain article in the $E n$ quirer had been written by a person formerly in his employ. I can see him now, striding up and down the room, exclaiming, "I'll put a ball through him!" "I'll put a ball through him!" This sentence he repeated fully twenty times, and in a tone which gave assurance of a purpose quite as deadly as his words imported. Yet nothing came of it. He was a hearty 


\section{JOHN M. DANIEL'S LATCH-KEY}

and persistent hater, but he was not implacable. During his stormy life he had many fallings out and many makings up. It is not unsafe to assert that he never had a friend with whom, at some time, he did not have a misunderstanding; yet it is certain that he died in perfect peace, and on good terms with all, or nearly all, of his old friends. One of the last and most pleasing acts of his life was the glad acceptance with which he met the advance of his friend, Mr. Thomas H. Wynne, from whom he had been estranged during nearly the whole war.

His enmity to Mr. Davis, amounting to something like a frenzy, will be ascribed, by those who differed from him in opinion, to a bad heart, pique at not being made the confidential friend of the president, or at not having been sent abroad in a diplomatic capacity. But by those, on the other hand, who agreed with him in thinking that the cause suffered more from maladministration than from anything or all things else, his course will not be so harshly judged; and their chief regret will be that arguments so forcible as Daniel's were not left to produce their effect, unaided, or rather unimpeded, by diatribe and invective. To reconcile these conflicting opinions is impossible, and if it were not, is beyond the intent and aim of this sketch. I remember asking him once whether Mr. Davis ever saw his animadversions upon him.

"They tell me down stairs," he replied, "that the first person here in the morning is Jeff. Davis's body servant. He comes before daylight, and says that his master can't get out of bed or eat his breakfast until his 


\section{JOHN M. DANIEL'S LATCH-KEY}

appetite is stimulated by reading every word in the Examiner."

"Do you think he profits by its perusal?"

"Unquestionably. The few sound ideas he ever had came from the Examiner."

This he said with perfect sincerity, for he contended, both in the paper and out of it, that every wise and useful measure which had been promulgated by the administration or by Congress, was borrowed or stolen from the Examiner.

He was proud of his paper. If he sometimes regarded it as "a mill-stone about his neck," he nevertheless devoted his life to it, and found in it his chief happiness. He looked to it as a source of power and wealth in the future. Of that future, he was more sanguine than any man I ever knew. How well I remember the night he said to me, without provocation, if I recollect aright:

"I shall live to eat the goose that eats the grass over your grave."

Perhaps there was something in my appearance which called forth the remark, for I must have been worn by the enormous amount of work I was then doing.

I looked up from the table, where I sat writing, and said quietly:

"I don't doubt it; but what makes you say so?"

"Two reasons; I come of a long-lived race, and I have an infallible sign of longevity."

"What is that?"

"I never dreamed-my sleep is always sound and refreshing." 


\section{JOHN M. DANIEL'S LATCH-KEY}

Little did I then think that before two years were ended, I should see him in his coffin. He was mistaken, however, in saying that he came of a long-lived race. His father was not old when he died, and his mother was comparatively young when she came to her death-of consumption, if I mistake not. He was thinking, probably, of his uncle, Judge Daniel, more than his parents. His own health was never robust; his constitution was delicate, as a glance at his figure showed. His chest was narrow and rather shallow, though not sunken, and his hips were broad. The organs of digestion and respiration were alike feeble. He had had an attack of pneumonia before going to Europe, and during his whole life he was a victim of dyspepsia, from which he had suffered greatly in youth and early manhood. I often warned him against the injudicious and frequent use of blue mass, his favorite medicine. Great virile strength he had, as was shown by his dense beard and the coarse hair on his feminine hands, but in muscle, sinew and bone he was deficient. He took great care of himself. I was told that when he returned to Richmond his person was protected by a triple suit of underclothing. Next to his skin he wore flannel; over that, buckskin, and over that again, silk. This load of clothing he contended was indispensable to health in Turin, where the atmospheric changes were very violent and sudden. In Richmond he dispensed with some of this undergear, but probably gave up only the buckskin. Among other items which he gave a Maryland blockade runner, who waited on him one day while I was present, was an order for "one 


\section{JOHN M. DANIEL'S LATCH-KEY}

dozen silk shirts of the largest size." This size he particularly insisted on, and the inference was that he intended to wear them over flannel. What availed all these precautions when the final summons came?

Long as this article is, I cannot close it without some allusion to John MI. Daniel as an editor and as a man. He was born an editor. Whatever may have been his abilities as a diplomatist and a politician, whatever distinction he might have attained in the forum or in the field, his forte lay decidedly in the department of letters, and more especially in the conduct of a newspaper. He was not a poet, not a historian, a novelist, an essayist, or even, if I may coin the word, a magazinist. He had talent enough to have excelled in any or all of these, but his taste led him in another direction. It was hoped by everybody that he would on his return home write a volume about his residence in Europe. Such a book would have been exceedingly interesting and valuable. But he was not a book-maker. Moreover, it is not improbable that he expected to return to diplomatic life, and did not wish to embarrass himself by reflections upon the manners and customs of the people among whom he expected to reside. He could not have written about the Italians or any other people without dipping his pen in vitriol. The publication of a part of one of his letters to his friend, Dr. Peticolas, had brought him into trouble with the Italians, and made him furious with his associate, Hughes, who took charge of the Examiner in his absence. This occurred early in his career as a diplomat, and made him cautious. He preserved his dispatches with ut- 


\section{JOHN M. DANIEL'S LATCH-KEY}

most care, in large handsomely bound volumes; but whether with a view to publication or for his own use in after years, I am unable to say.

I remember his telling me one night that he intended to make a book.

"I wish you would," said I.

"Mark you, I did not say write a book, but make a book."

"What do you mean?"

"I mean to make a book with the scissors," he replied.

"How so?"

"Why, by taking the files of the Examiner from its foundation to the present time, and clipping the best things from them. I am sure that I could in this way make a book, consisting of a number of volumes, which would contain more sense, more wit and more humor than anything that has been published in this country for the last twenty years. Similar publications have been made in England in modern times, and long since the days of the Spectator and the Rambler, and they have succeeded. I believe that the best things which have appeared in the Examiner, if put into book form, would compare favorably with any English publication of the kind, and that the book would command a ready sale."

So far as my personal knowledge goes, this is the only book which John M. Daniel ever thought seriously of making. I agreed with him then, and I can but think now, that the present owners of the Examiner would do well to carry out his views. In the impover- 


\section{JOHN M. DANIEL'S LATCH-KEY}

ished condition of the South, at this precise time, it is idle to expect a very large sale of any publication whatsoever; but the day will come, I trust, when the bound volume of selections from the Examiner will have a place in every Southern gentleman's library.

John M. Daniel was emphatically an editor-not a newspaper contributor, but an editor and a politician. He was enough of the latter to have made a name in the cabinet. He was no orator, although he had an orator's mouth. I never heard of his making a public speech. He must have had a great natural repugnance to speaking. Could he have overcome this repugnance, he had command enough of language to have ensured him considerable distinction in forensic display; but his temper was far too hot and quick to admit of success in debate. He knew men, in the light in which a politician views them, thoroughly well. His natural faculty of weighing measures and of foreseeing their effects was much above the common. He had in him the elements of a statesman. His historical studies and his knowledge of mankind were not in vain. Before the first blow was struck, and when both Mr. Benjamin and Mr. Seward, speaking the sentiments of their respective peoples, were issuing their "ninety days notes," he prophesied not only the magnitude, but the inhuman and unchristian ferocity of the late war. And who, in this sad hour, can forget how, as the struggle drew near its close, he strove day after day and week after week to revive the flagging spirits, and to kindle anew the energy and courage of the Southern people, by terrible pictures of the fate which has ever 
attended "oppressed nationalities?" It is true that these articles were written by John Mitchell; but they were inspired by Daniel. Alas! those prophecies, like all others, have been interpreted fully only in their completion.

As a politician, eminence was not his. Had he lived, it is as certain as anything human can be, that he would have filled an honored niche in the temple of political fame; but his celebrity was destined to be confined to the domain of journalism. Therein he obtained a distinction which has been surpassed by none and equalled but by few American journalists. His place is by the side of Thomas Ritchie, Hampden Pleasants and Joseph Gales. As an editor, he was to politicians what the Earl of Warwick was to kings.

"It is said," he remarked to me one day, "that my admiration for Floyd is due to the fact that Floyd made me. The truth is, I made Floyd."

He was accustomed to magnify his office of editor, and his exalted opinion of General Floyd was based, not upon gratitude, but upon his estimate of the man himself. It has been said that the quality which women most admire in men is "strength." The assertion holds equally good of man's admiration for man, and is particularly true in regard to John M. Daniel. He worshipped strength, and nothing but strength of mind and of body. He despised fools and weaklings of all sorts. Goodness-the moral qualities -he threw entirely out of the account. He did not much believe in the existence of these qualities, and when they did exist, he regarded them as but evidences 


\section{JOHN M. DANIEL'S LATCH-KEY}

of weakness. Floyd was his "man of bronze"-therefore he liked him. Of another and more distinguished politician he would speak in terms of extreme contempt. "He snivels-he weeps," he would say, in tones of indescribable disgust. Often have I heard him expatiate upon Wigfall's magnificent physique and his unmistakable natural courage. "It is the genuine thing," he would say. "There is no put on there. He has got native pluck-the actual article; it is no strain on him to exhibit it. The grit is in him, and you can't shake him."

Of Daniel's own courage, I think I can speak safely and correctly; and I may as well do so here, although I had intended to defer mention of it until I came to the discussion of his character as a man.

He did not have the hard animal bravery of Wigfall; it was not in his constitution. His highly wrought nervous system was not sufficiently panoplied with brawn to ensure it against the agitation arising from a sudden shock or the violence of an unexpected attack with the fist or club. Nor was he of that tough and wiry make which enables some fragile men to meet the rudest physical assaults without an outward tremor. But he had courage of another sort, and had it in a high degree. What is generally called moral courage, but is more properly intellectual courage-that is, bravery which is founded not upon combativeness, the consciousness of muscular strength, or upon great excitability unrestrained by caution, but upon the clear perception of the nature and extent of danger, together with the hardihood of great self-esteem and pride of 
character-he possessed to an extent which is rarely seen. To make a reputation, he commenced his editorial career by attacking personally nearly every man of note in Virginia, thereby incurring a responsibility in the field and out of it-for it rested with the parties assailed to demand satisfaction according to the code or to take it at the pistol's mouth in the street, as seemed best in their eyes-which few men of the strongest nerve would have dared to assume.

He lived in a land where duels were common; in a city where the editor of the Whig had been slain but a few years before, and among a people who never entertained the first thought of accepting damages at law as reparation for a personal affront; hence the course of the Examiner during its earlier years was attended with a degree of danger which none but a truly daring or a foolhardy man would ever have encountered. But Daniel was no fool; and although he lacked caution and allowed the bitterness of his feelings to carry him too far, he was anything but reckless. Appreciating fully his danger, he willingly risked his life and his reputation in order to secure the advantages which lay beyond the point he so coolly braved. To carry his point, he accepted cheerfully the odium of the community, and, indeed, of the whole State in which he lived. For the sake of power and a competency, he became an outcast from society. At one time he was literally hated or feared by everybody. In the whole world there was scarcely a human being who really liked him for himself. All this he brought upon himself, deliberately and for a purpose. He 202 
marked out an arduous course, and he followed that course resolutely to the last day of his life, accepting all the consequences. Surely, neither a weak nor a timid man could have done this. Assaulted suddenly in the streets by a powerful man, of known courage, who threatened then and there to cut his ears off, it is not to be wondered that the fragile man showed some agitation; but his intrepid "you shall have your duel" in the admirable correspondence with Elmore, and his calm bearing on the field in the very presence of death (for his adversary was no trifler), proved beyond question that John M. Daniel had that within him which men in every age have recognized as genuine courage.

To return from this digression: He was an editor in the best and fullest meaning of the word. He could not only write himself, and write well, but he could make others write well. The crudest articles, as I have shown, if they had but the germ of something good in them, could be transformed by him in a few moments, with an ease and an art peculiarly his own, into powerful lcaders. A touch or two of his pen gave a new coloring to a contribution and made it his own. He had the power of infusing his spirit into every part of his paper, and of giving it thereby an individuality which made it as attractive as it was unique. He had innumerable editorial contributors, but they all caught, insensibly and quietly, his spirit, his very tone; and there was about the Examiner, whenever he was at the head of it, a homogeneity which under other managers it never attained. It was easy to tell when he left the paper and when he 203 


\section{JOHN M. DANIEL'S LATCH-KEY}

came back to it. His precise articles could not always be told, but there was a nameless something about the paper, as a whole, which gave indubitable evidence of his presence. The very arrangement of the printed matter and the allocation of articles betrayed him behind the scenes. He brought with him, as often as he resumed the helm, a magnetic charm which drew to the paper the cleverest things which were written by anybody. Whoever chanced to do a good thing with the pen was anxious for it to appear in the Examiner. There it would be read by more people and be better appreciated than in any other paper. The credit would be Daniel's, but what of that? The intellectual bantling would be sure not to die still-born. It would make a noise and be talked about; its unknown parent would hear its praises and be secretly proud.

Many men have written for the Examiner, and some have conducted it with ability; but it has never been, and it may be fairly reckoned that it never will be, edited as it was by John M. Daniel. He had not the humor, and he may not have had the wit of some of the contributors; nor did he have the financial knowledge or the scientific attainments of others who wrote for him; but he made a better editor than any or all of those combined could have made. The truth of this assertion will be understood fully when I call the names of some of his contributors. They are as follows: Robert W. Hughes, Patrick Henry Aylett, William Old, Dr. A. E. Peticolas, Edward A. Pollard, L. Q. Washington, Prof. Basil Gildersleeve, John R. Thompson and John Mitchell. Some of these gentle- 
men have had the paper entirely in their charge for months at a time, but it is no disparagement to them to say that the paper in their hands was never what it was in the hands of John M. Daniel. He had in him an intensity of bitterness which they did not possess, and would not have displayed if they had possessed. He had a strength of originality, an art of attracting contributions and of shaping them into his own similitude, and what is most to the point, a painstaking attention to the minutiæ of the paper, which, combined, made him an editor whose equal, in all respects, has never been seen in this country.

He had little, and if his own opinion were taken, not a particle of humor. He was too bitter for that. But he had the quickest and keenest appreciation of the humorous. Dickens was a favorite with him. Nay, he had, he must have had, humor of his own. Wit he had in a high degree, and of every sort; but he was particularly happy in nicknaming and in personalities of all kinds. Some of those names showed both wit and humor; as when he called the cadets of the Virginia Military Institute, on the occasion of their first visit to Richmond, "kildees," a title which, as it seemed to belittle them, made the cadets very angry, but which was, nevertheless, so appropriate and so harmless that everybody laughed good-naturedly at it. The appellation of "leaden gimlet," which he applied to a certain lawyer in Richmond, is an example of galling satire, without the least admixture of the milk of human kindness. The office of Mr. Benjamin, the Secretary of State, contained files of the leading news- 


\section{JOHN M. DANIEL'S LATCH-KEY}

papers of the Confederacy; and hence it was called by Daniel "the Confederate Reading Room"-a name intended to convey his contempt at once for the office and the official who occupied it.

He had a lively fancy, but little or no imagination in the higher sense of the term. Certainly he had not the creative faculty. I do not know that he ever attempted rhyme, much less poetry or dramatic characterization. His mind was logical, but dry and elaborate argumentation was not to his liking. $\mathrm{He}$ caught readily the salient points of a question, and aimed, in writing, to present them forcibly, but not with too much brevity. I saw him return to the author a number of editorials which I thought excellent, and asked him why he did so. "They are well written," said he, "in fact, they are elegantly written; but there is no incision in them."

His reading was various and extensive, his memory first-rate. He told me that, during his residence abroad, he not only made himself familiar with Italian and French literature, but read, in addition, every Latin author of celebrity, and many whose names were almost wholly unknown. Greek he neglected, and he paid little attention to German. History, biography, memoirs, political treatises, novels, poetry, and essays of the better class, he literally devoured, and retained with wonderful fidelity everything of importance that he had ever read. He cared little, I think, for metaphysics, or for the exact sciences, and discovered less information in regard to anatomy and physiology than many men of ordinary capacity and edu- 


\section{JOHN M. DANIEL'S LATCH-KEY}

cation. He was not, strictly speaking, a learned man. His taste was pure and correct; his love of "English undefiled" very great. Yet he was not a slavish purist. His peculiar spelling was but a mark of his infinite detestation of Webster as a New England Yankee. His favorite authors were Voltaire and Swift. The latter was his model. He often urged me to study Swift diligently, in preference to Addison, Dryden, Milton, or any other English author, ancient or modern.

It remains for me to speak of him in his personal character, and this I shall do as briefly as I can. He who has ever looked unflinchingly into his own heart will be slow to bring against another the accusation which so many were fond of bringing against John M. Daniel-that he was "a bad man." That he was essentially and thoroughly "bad," no one who knew him intimately will charge. De mortuis nil nisi bonum. Upon that principle alone I should exonerate him from the charge. But more than that, I saw and heard too much to allow me, for an instant, to yield assent to every sweeping indictment against the character of the dead Virginian. Whilst he was yet extremely poor, he went twenty miles to lend a still poorer friend some money; and, at the same time, to save himself an expense which he could ill afford, walked the whole distance between Richmond and Petersburg and back again. This does not argue a bad heart. He bore his poverty manfully, denied himself and "owed no man anything." Such is not the wont of bad men. I know it gave him sincere pleasure to compose a quarrel, and, when called upon, he exerted himself 


\section{JOHN M. DANIEL'S LATCH-KEY}

energetically to accomplish that end. But bad men prefer to stir up strife, rather than to allay it. I know that he made a trip to Charlottesville for the purpose of buying a house advertised for sale at auction, which house he intended to rent cheaply to me, in order that I might escape the grinding exactions of city landlords. And this he did at my request. Is it the habit of bad men to undertake such journeys in the interest of those who have no special claim on them? I know that at a time when nearly every property owner in Richmond seemed almost conscienceless in their extortions, the houses purchased by John M. Daniel, and fitted up by him at no trifling expense, were rented to his assistant editors on terms most reasonable. Is this the practice of bad men? That Daniel was not liberal and openhearted I will admit. But he was not a screw. He was just, upright in his dealings, prompt to the minute in all his payments. His printers, his writers, all in his employ, were better paid than those in any other newspaper office in the city. If this be the habit of bad men, what pity it is that the world is not full of them!

That he treated his relatives with unkindness, and that the hardships he endured in the days of his poverty were no sufficient excuse for this unkindness, no one who has heard both sides of the question will deny. But the man was morbid, both in body and in mind. One of the evidences of insanity laid down in the books is a causeless hatred of the nearest and best relatives and friends. I do not say or believe that John M. Daniel was insane. Nevertheless, his bitterness 208 


\section{JOHN M. DANIEL'S LATCH-KEY}

toward people in general, and toward certain kindred in particular, betokened anything but mental soundness. His body, perhaps, was never entirely free from disease. The tubercular disposition, with a tendency to development in that part of the system (the digestive organs) the disorders of which are known to affect the mind more powerfully than any others, may account for many of those unfortunate peculiarities which contradistinguished him from healthier and happier men. Had he possessed a florid complexion and a robust organism, who believe that his faults would have been the same? Temperament is not an adequate excuse for every failing, but due allowance should ever be made for its influence.

Added to his bodily infirmities, there was a want of faith in human nature and its Great Author. Yet he was by no means an atheist, but rather a deist. I questioned him very gravely one day concerning his belief in God. He paused for some time, and then answered very cautiously and vaguely. The impression left on my mind was that he believed in a Great First Cause, but wished for more light. Touching the revelation of the New Testament, he gave no opinion. He seemed, however, to think that really nothing was known in regard to the "bourne whence no traveller returns."*

* The following incident, recently communicated to me, may be relied on as strietly true, and serves still further to illustrate Daniel's character:

Dr. Rawlings said to Walker some weeks before Daniel's death: "Walker, Daniel must die. You seem to be able to talk to him at all times without offending him, and, if you think proper, the next time you find him in a calm frame of mind, you 
When this subject was broached, neither of us dreamed that he was so soon to explore that unknown world, which lay dark and unfathomable before him. But a few evenings before he had congratulated himself upon the position he had gained in the world.

"I am still young," said he; "not very young, either, for I will soon be forty. But I know no young man who has better prospects than myself, and few who have done so well. I suppose I am worth now nearly one hundred thousand dollars in good money. The Examiner is very valuable property, and destined to be much more so. I expect to live long, and, if I do, I shall be rich. When I am rich I shall buy the old family estate in Stafford County, and shall add to it all the land for miles around. I shall build a house to my fancy, and, with my possessions walled in, I shall teach these people what they never knew-how to live like a gentleman."

may ask him if he would like to converse with a minister of the Gospel." Knowing Daniel's dislike to most preachers, Walker thought over the matter several days before he could muster courage to bring up the subject. One morning when he seemed stronger and perfectly free from pain, Walker sat some moments, very nervous and almost afraid to allude to the matter; but at length he said: "Mr. Daniel, you have always thought a great deal of Dr. Hoge; you believe he is a sincere, good man." $\mathrm{He}$ replied, very promptly, "Well, what of it?" Walker answered, "You are very ill, and I thought perhaps you would like to have him call on you and talk with you." He looked up, smilingly, and said, "Walker, I am no woman! I don't want any one but yourself to come into this room except the doctor." He never alluded to his being dangerously ill save once, when he said to Walker, "Send word to your wife that you will sleep in my house to-night. Something may happen before morning, and I want you with me." 
Such, in effect, and almost in words, was the picture he drew of his future. It was the first and only time I ever knew him to indulge his fancy in building air castles.

I may add, as one additional proof that he was not an atheist, the fact that he made it a rule to publish in the Examiner, on cach succeeding New Year's day, a poem in honor of the Deity. He did this, not merely because he thought it a becoming and good old custom, but because it was real gratification to him to do so. He bestowed much thought on the selection of this New Year's poem, singled it out months beforehand, and sometimes consulted his friends to ascertain whether there was not some poem of the kind with which he was not acquainted. He certainly asked me to aid him in making such a selection, and I have no reason to believe that he did not consult others also.

He hated men, but not mankind. To the latter he was indifferent. But he despised men more than he hated them. It had been his misfortune to view men from two inauspicious standpoints-from poverty on the one hand, and from power on the other-and in each case the picture was distorted by the medium of a morbid physical and mental nature. Proud, with the pride of an acute and bold intellect, he fancied, in his days of penury, that he was contemned and neglected, when he knew he had that within him which was to be neither neglccted nor contemned. After he had proved this, after he had become famous, prosperous and powerful, he despised men, because he fancied they envied him his prosperity, feared his power and hated himself. "Man pleased him not; no, nor 
woman either," because his sad experience had taught him to suspect the purity of all motives. A little genuine humility, a moderate degree of success, achieved in some other way than by attacking and overpowering antagonists, would have made him a happier, wiser, and better man. He dreaded power in others, because, as he confessed to me, he knew its baneful effects upon himself. He had no faith in men, because he knew how terrible would be the consequences if no obstacle stood between men and the accomplishments of their secret desires. He startled me one day by saying: "How long do you think you would live, if your enemies had their way with you? Perhaps you think you have no enemies who hate you enough to kill you. You are greatly mistaken. Every man has his enemies. I have them by the thousand, and you have them too, though not so numerous as mine. Neither your enemies nor mine would run the risk of murdering us in open day. But suppose they could kill us by simply wishing it? I should drop dead in my tracks before your eyes, and you, quiet and unknown as you are, would fall a corpse in Main Street before you reached home."

He owned that this horrible thought had been put into his mind by some writer whom he had that day been reading. But it was precisely such ideas that fastened themselves in his memory. He brooded over them until they became a part of his very being. No wonder he was morbid!

Here I must stop, for I have told all, or nearly all I know about this remarkable man. The narrative has 


\section{JOHN M. DANIEL'S LATCH-KEY}

spun out under my hand to a length very much greater than I intended when I began to write. But I have willingly allowed myfelf to go on, knowing as I do that every word about John M. Daniel will be read with interest in every Southern State. It is to be hoped that at some day those who were his intimate friends will do perfectly what I have done most imperfectly, for lack of knowledge on the one hand, and because of countless interruptions on the other. Written piecemeal, this sketch claims no other merit than a faithful account of my acquaintance with its subject, and an estimate, which I deem to be just, of his character. I trust it will be viewed in this light, and that it may not provoke one harsh criticism. If Messrs. P. H. Aylett and T. H. Wynne, or Doctors Rawlings and Petticolas, could be induced to attempt what I have undertaken, then the Southern public would have what so many desire to see, a full-length portraiture of one of the most gifted and brilliant men ever born on Southern soil.

A few words about his death, and I have done. Late in January, 1865, he was attacked the second time with pneumonia. Treated promptly by skilful physicians, his disease abated; he rallied, and was able to sit up and attend somewhat to his duties. His recovery was deemed certain. But, as the event proved, tubercles were developed both in the lungs and in the mesenteric glands. The patient gradually grew worse, and was at length compelled to return to his bed. The slow weeks of winter wore themselves away. How they passed, I cannot tell, for, although I made 


\section{JOHN M. DANIEL'S LATCH-KEY}

frequent calls at the house on Broad Street, I was always refused admittance. The latch-key remained unused in my pocket. Only his physicians and most intimate friends were admitted to the sick man's chamber. On one occasion, as I was told by a Kentucky member of the Confederate Congress, he sent for the Hon. R. M. T. Hunter, and one or two other prominent politicians, and told them his candid opinion -that the Cause was hopeless, and that the only course left to us was "reconstruction on the best terms we could make."

So long as his strength permitted him to take an interest in any earthly thing, he had the welfare of the Southern people at heart, and his latest effort seems to have been to secure by negotiation what he was persuaded arms could not achieve. Those who outlived him can decide for themselves whether the conqueror would have kept the faith which might have been plighted at Fortress Monroe better than that which was so solemnly pledged at Appomattox Court House.

As spring approached, his symptoms became alarming. Ere long, it was whispered on the streets that his situation was critical. Relatives and friends proffered every assistance. They were politely but firmly told that assistance was not needed. He was not a man to be "sat up with." His only attendant was a female servant. Once or twice, perhaps oftener, he requested his faithful manager, Walker, to sleep in an adjoining room; but Walker was hardly warm in his bed before he was aroused by a message to the effect that Mr. 
Daniel wished to see him. Iturrying on his clothes, he would go at once to the dying man's bed, where, in a feeble voice, this strange announcement would be made to him:

"Walker, you must really pardon me, but the truth is, that the very fact of your being in the house makes me so nervous that I cannot rest. Please go home."

Home the manager of the Examiner would go, sometimes long after midnight, leaving the sufferer to his own thoughts. What those were, no man will ever tell, for none ever knew. He must have known that his days were numbered, for when he received a bouquet of the earliest spring flowers, sent him by the daughter of his friend, Mr. Wynne, he took it in his wasted hand, returned his thanks for the gift, and then laid it aside, murmuring "too late now; too late!"

The editorial conduct of the Examiner had been in the exclusive charge of John Mitchell for many weeks. Daniel no longer concerned himself about it. His will was made; he was ready to depart. His physicians knew he could not live, but they expected him to linger ten days or a fortnight longer. Plied with stimulants, he might bear up yet a good while. But the last hour was at hand. The exact circumstances of his death, as told to me, are these. On making his usual morning call, Dr. Rawlings found his friend's pulse sinking rapidly. No stimulant bcing at hand, the supply in the house having been exlrausted, he dispatched a servant in all haste to get a bottle of French brandy. It was quickly brought. When it came, he proceeded forthwith to make a strong toddy. The patient was 


\section{JOHN M. DANIEL'S LATCH-KEY}

then lying close to the outer edge of the bed. Dr. Rawlings stood some distance off, near the window, stirring the toddy. Suddenly his attention was aroused by a noise behind him. Looking quickly in that direction, he saw that the patient had, by a strong effort, turned himself over and lay on his back in the middle of the bed, with his eyes closed and his arms folded on his breast. Thinking that he was praying, he would not disturb him, but continued to stir the toddy a few minutes longer, so as to give him time to finish his prayer. A sufficient time having elapsed and the need of a stimulant being urgent, the doctor went to the bedside and leaned over.

John M. Daniel was not in this world! 


\section{VIII}

\section{THE VIRGINIA EDITOR}

[The following sketch was written and published some time in the fifties, when there may have been more to excuse its extravagancies than now. The satire amused the public, and no portion of it more than the gentlemen who were the object of it.]

$T_{\text {perate, pugnacious, gambling gentleman. Be- }}^{\text {HE Virginia Editor is a young, unmarried, intem- }}$ tween drink and dueling-pistols he is generally escorted to a premature grave. If he so far withstands the ravages of brandy and gunpowder as to reach the period of gray hairs and cautiousness, he is deposed to make room for a youth who hates his life with an utter hatred, and who can't keep drunk more than a week at a time.

Deposed, he becomes a literary ostrich, and may be seen, with swollen red nose and diminished, calfless shanks, migrating from court-house to court-house, laying a newspaper egg, which he leaves to be hatched into life and permanence by the pecuniary warmth of the party to whom he sells out at a small advance. Or he gets the lofty position of clerk in Washington. Should he, by rare good luck and the miraculous interposition of Providence, have saved any money, he buys a property in the country, retires to it, debauches 
himself with miscellaneous literature, lounges much and does a great deal of nothing at all. Should he get married, he sinks into an obscure and decent citizen, and looks back upon his early career as a horrid dream.

Previous to his death, the Virginia editor makes the most of the short time allotted to him on earth by living at a suicidal velocity. To test the strength of his constitution, by subjecting it to the influence of the most destructive habits and agencies, appears to be his sole pleasure and aim. $\mathrm{He}$ is determined not to live longer than he can possibly help. A quiet death at a ripe old age he regards as a disgrace.

His first waking moments in the morning are saturated with a number of powerful cocktails, to cure a headache, "brought over," as an accountant would say, from the previous midnight. Cocktailed past the point of nervousness and remorse, he dresses himself and wends his way to a barber shop to get shaved, if he shaves at all. Not unfrequently he has himself shaved in bed. Breakfast succeeds, and then, with a cigar in his mouth, he enters his sanctum and goes to work; which work consists in hunting for insults in his exchanges, and in laying the foundation, by means of a scathing article, of a future duel. While employed upon his leading article he suffers no interruption, except from the gentleman who brings a note from another gentleman, whom he (the editor) grossly insulted at an oyster supper the night before. Having no earthly recollection of any such occurrence, the editor feels no hesitation (unless he happens to be unusually bilious, or has no "affair" upon his hands), 
in saying that he "fully and frankly withdraws any and every expression reflecting upon the character of the gentleman, as a gentleman and a man of honor."

His editorial labors vary from five minutes to two hours and a half in duration. If he feels very badly he won't write at all, but goes armed with a stick to a neighboring law office, and threatens the occupant with a caning unless he has a spicy article in the compositor's hands by such an hour. The unhappy barrister complies, and spices the editor into a scrape, for which the editor is unaffectedly thankful, swearing he would die without excitement.

Before leaving his sanctum he answers a couple of letters which arrived by the last mail. He engages to meet "the gallant Democracy of - district," and to address them on "August court-day." He assures a "constant reader" that "the glorious cause is prospering, the skies brightening"; and suggests, as the best means of putting the issue of the canvass- "the most momentous canvass that ever occurred in the history of the Republie"- -beyond a doubt, that the "constant reader" shall send in ten new subscribers to the Keepa Pitchinin. He then huddles a shirt, a case of dueling pistols, and a bottle of "Otard" into a small trunk, and goes to the telegraph office to notify a brother editor that he will be in Washington to-morrow night, waiting for him at the National Hotel. His mind being thus relieved of business, he has nothing to do but wander off to his hotel, to look at the register and see if anybody has come. Meets there another editor-a red-headed provincial fresh from the mountains, and 
already heavily laden with "rifle whiskey"-with whom he proceeds, without delay, to drink juleps and talk politics until dinner-time.

After dinner he borrows twice as much money as will take him to Washington and back, reserving the surplus to bet that night at the faro-bank.

In his personal appearance, the Virginia editor vibrates between positive gentility and absolute shabbiness, and this irrespective of his condition as to "funds." At times he is smooth and clean of face, immaculate in shirt, perfect of boot and hat; at others he is great in beard and dirt, resembling an uncleansed pressman, or a pirate who has cruised for years upon an ocean of ink. He rarely buys clothes until he is in immediate need of them; and, inasmuch as he lives all over the State, is quite as apt to have on somebody else's clothes as his own. He despises a fashionable, dandified man as he does a man who drinks weak drinks. He vindicates his Democracy, even in his liquor; believes in good old brandy or whiskey, calls them "strict construction drinks," while malt liquors he stigmatizes as "compromise drinks," and will have nothing to do with them, except to "taper off" on.

There is nothing in his form or features to distinguish him from other men. A physiognomist might, perhaps, detect in his face a bloody good-nature-an amiability easily kindled into anger-as if the fierce animal instincts of the man were but imperfectly subdued by the pressure of social refinements.

His negligence in dress is not greater than his carelessness with regard to another comfort which the ma- 
jority of mankind deem essential to happiness. He will live upon the best of food, will drink the best liquors, and smoke the finest cigars, but is utterly indifferent as to where or how he sleeps, provided he has a bed-fellow; for he is greatly social, and cannot bear ever to be alone. No respectable young man living in the same city is secure against an invasion of the editor at the most inopportune hours of the night. How many sweet dreams have been rudely broken by his assaults upon the front-door, or his noisy escalade of the back-window, it would be impossible to tell.

He has a room of his own, originally furnished with some taste and care, but has a mortal antipathy to sleeping in it. Nor is this aversion to be wondered at. Through a puddle of newspapers, congressional speeches, tobacco juice, cigar stumps, broken spitboxes, and pipestems, he wades to a bed whose sheets bade adieu to the washerwoman at a period too remote to be recalled, and whose counterpane secretes its primitive tints under a sweet and greasy scum of spermaceti and spilled brandy toddies. A candlestand is drawn conveniently near the yellow pillow, and on it lie, disorderly, a candle burned to the socket, a fragmentary volume of Byron, a plug of tobacco, a cork (fellow to others on the floor), an inkstand without any ink in it, and a foolscap scrap of unfinished editorial. Upon the window-sill, near the foot of the bed, stands marshaled a platoon of various-sized bottles, from the grenadier champagne to the squatty porter and the slab-sided tickler. In the little wardrobe are no clothes, except a skelcton waistcoat gibbeted upon 
a broken hook, but a number of empty cigar-boxes, a bowie-knife and a revolver. In the waistcoat pocket may be found a free railroad ticket, which ticket he never presents, for the conductors are much better acquainted with him than with the schedule. The odor of this apartment is not inviting. The door is always open, night and day, and it is the common dormitory of all belated roysterers. Any one may sleep here who chooses.

Notwithstanding his habits, the editor obtains a popularity wholly disproportioned, one would say, to his merits. That he should achieve notoriety is no matter of surprise, when every number of every paper issued in the State contains the name of Derringer Thundergust, or William Jeems Rawhead, as principal, second, or adjustant of some personal difficulty; but notoriety is one thing and popularity another and very different thing.

Habits which would outlaw any other man enable him to ride rough-shod over the inviolable law of custom. Conduct which would damn a man in business endears him to men in whose creed "strict business habits" rank next to, if they do not take precedence of, godliness. Grave men-the slaves of routine and propriety-appear to take the same delight in witnessing his unbridled eccentricities that inspired the poet Job when contemplating the gambols of the wild ass. There is an airy bravado in his outrages, a gay candor and naturalness in his excesses, which extract all their sting. As soon quarrel with the habits of a strange bird as with those of a being who is not a man, but an 


\section{THE VIRGINIA EDITOR}

editor, and to whom no gauge of human morals is in any particular applicable.

His abhorrence of the vice of solitary drinking has a good deal to do with this popularity. Scarcely a respectable citizen can be found in the commonwealth with whom he has not, at some time or other, hobnobbed in a friendly manner. Rather than drink alone he will drink with a negro, provided the negro is at all genteel, and has a gentleman for his master. His Ethiopian popularity is immense. It could hardly be otherwise when, from the White Sulphur Springs to the City of Norfolk, he has repeatedly and extravagantly feed everything answering to the name of "waiter."

The Virginia editor is not a pious, nor, strictly speaking, a gallant man. Women, children, and preachers he classes under the common head of "non-combatants," and views them pretty much in the light in which he regards flies-as species of not very harmful, somewhat abundant insects, perhaps useful, but whose uses are not yet well understood. Still, he makes it a point of honor to place implicit faith in the truth of the Christian religion and the virtue of women; and while he regards the softer sex as, at best, beautiful toys, they are glass toys, and he treads respectfully and gingerly among the frail vessels. He clings with sectarian tenacity to the belief in future rewards and punishments; he is too brave and resentful a man to think otherwise. A disbelief in hell he denounces as the "poltroonery of infidelity," nor can any casuistry convince him that a man is not as responsible for his faith as he is for his actions. 


\section{THE VIRGINIA EDITOR}

He loves to talk, and his great theme, after politics, is himself. In himself he has the most unbounded confidence-a confidence which, in the most trying emergencies, scarcely ever deserts him. Through difficulties that would appal and crush ordinary men, he moves with the smiling abandon of a knight-errant pricking onward to meet a dragon, gorgon, or chimera dire. Only in moments of extreme nervous depression will he admit himself not competent to the discharge of the most arduous and varied duties of life, and especially of those duties for which he is evidently unfitted. He looks upon himself as pre-eminently a man of business-a practical man. Rothschild was not his equal in financiering ability; Napoleon nor Hampden could have wearied him in work; Halifax was not his superior in political sagacity. Name any man who has succeeded or failed in any undertaking, he will instantly unfold to you the secret of his success, or the oversight which led to his downfall.

"But for cards and liquor," himself would have excelled any man of his acquaintance; as it is, see how well he gets along in the world. In truth, his mind is strictly of the nil admirari order; he worships no man; and his regard for himself is only a reluctant indulgence accorded not to what he is, but to what he ought to be, and would be, "but for cards and liquor."

For this remarkable self-confidence he is indebted partly to a nature eminently high-spirited, and partly to his position. Like the driver of a locomotive, he wields a power infinitely greater than his own. $\mathrm{He}$ 


\section{THE VIRGINIA EDITOR}

handles the lever that unlooses the throttle-valve of the mightiest engine on earth, and it is but natural that he should confound derived with individual power. Disconnect him from his engine, let him conduct a business, other than his own, upon the same loose principles, he would soon discover his error. But then he would lose one of his most delightful traits.

The Virginia editor is not a profoundly learned man; he is not even a smatterer, in the sense, at least, in which that equivocal compliment was paid to Milton. His specialty is politics; and his tastes not less than his occupation conspire to prevent his acquiring any other knowledge. Of Latin he remembers a few terms, such as $e x$ post facto and $e x$ parte, which he picked up while drifting, for a few weeks, through a law office. Of Greek he retains nearly the whole alphabet, being only a little uncertain as to the relative shapes of Zeta and $\mathrm{Xi}$, and confusing Phi with Psi. His stock of poetry consists of a few scraps of Hudibras, Byron, and Peter Pindar; he has, besides, a professional pride and tenderness for the quatrain commencing:

“Truth, crushed to earth, will rise again!"

It would be impossible to restrain him from quoting this occasionally, and, if it were possible, it would be cruel.

His historical information does not extend quite to the times of the Achæan League and the Amphictyonic Council, but dates rather from the Resolutions of '98. With the workings of the American government, from 
its inception down to the present time; with the character, and, to an extent, with the writings of the great men who took prominent part in its formation; with the policy of the party leaders; with the politicians, great and small, of his own times, and with their tactics, he is intimately familiar. In fact, his attainments may be summed up in the word "politics"; for while he does not underrate those who understand and take an interest in Belles Lettres and the Arts and Sciences, he frankly confesses that he knows and cares nothing about them himself. So fitted is he for partisan journalism, and so wedded to it, that it is to be hoped the divine economy has set apart some waste democratic star, some uncleared portion of the celestial public domain, some half-settled nebulous Kansas as a newspaper heaven for him and his fellows. Elsewhere no conceivable use could be found for them.

His style in writing varies from the plainest AngloSaxon to the most gorgeous highfalutin. In general, however, he makes use of ordinary English, and cares little or nothing about nicety and finish. He is better at repartee than at argument, but prefers hard talk to the most polished wit. His humor is peculiar, and considerably wider than it is subtle.

It has been said by some that the Virginia editor is chosen rather for the stoutness of his heart than for the brilliancy of his intellect, and, to be honest, there is some truth in the allegation. A newspaper, to be successful in the Old Dominion, must not be defective in what they call chivalry; and a long-established paper, having the prestige of high-toned valor, would 
hardly employ a ready-writing craven in preference to a brave gentleman less facile with the pen. But the requirements of the public in this regard, and the usages of the papers, have been a thought exaggerated.

It is not true, for example, that the man-of-all-work, the "Cæsar" of the office, who is employed to sweep out the old papers and trash in the morning, receives an additional compensation for sweeping in the dead editors lying about the door, who have been killed at various places during the night and brought there, as to a Morgue, for recognition and distribution. Neither is it true that a paper, in order to keep up its circulation, must have at least one editor killed a day, and that papers having secured a good editor, one whom they are unwilling to lose, are in the habit of imposing upon the public by buying up worthless wretches to assassinate in place of him. Equally unfounded is the report that papers impoverished and doing a small business are forced to practice the contemptible fraud of substituting wooden dummies, manikins, or lay figures in place of bona fide corpses. These reports have reference, doubtless, to States farther south than Virginia.

A propensity for gaming is a part of the editor's constitution-an hereditary taint, for which he is no more responsible than for the age of his grandfather, and which he could as easily get rid of as remove the shape of his legs. The affliction being eminently genteel, he not only bears up under it with manly fortitude, but cherishes it with much regard. $\mathrm{He}$ is not 
much of a hand at "short cards." His delight is to be seated over against a grim, imperturbable faro-dealerto have bets of "red checks" all over the table-half a dozen "piddlers" of "white chips" to be leaning over his shoulder and admiring his nerve-a negro to be patiently awaiting the end of the deal to hand him a brandy toddy on a silver waiter-for the game to be stoutly contested, and himself to "come out right smartly winner." He has no great faith in "cases," but believes in betting on three cards at a time, and has a special hankering for "the pot."

After all, and in spite of his many faults, the Virginia editor is a gentleman. He comes of a good stock, and, however wild he may be, never disgraces it by a low or mean action. His vices are not those of a groveling spirit. If his temper is hot, it is not implacable; if his resentment is quick, it never seeks an underhanded revenge. If he' prefers a clean bullethole to a fisticuffish bruising or mangling with a bludgeon, that is his own concern. If he is a sturdy partisan, he is above the venality and the trimming which disgrace the journalism of States nearer the pole than his own. If he drinks too much, it is because the liquor he uses is of the best quality. If he gambles, it is because he can't help it. If he lives something beyond his income, he is doing no more than all enlightened nations and the majority of great men have done and continue to do. His tastes are lavish. An imperial gallon cannot be contained in a quart pot. And what political fabric was ever reared or maintained in its integrity without the aid of an occasional loan? If 


\section{THE VIRGINIA EDITOR}

he is not a very good citizen, it is because he wants to be a better editor.

Finally, half an ounce of lead is "honorably and satisfactorily adjusted" in his heart or brain, and the Virginia editor dies, to the great joy of himself and to the intense grief of his party - the faro-dealers, the barkeepers, and of everybody who is entitled to an unexpected fifty cents simply because he is a negro and can run an errand. The no longer belligerent remains are attended to the tomb by an immense concourse of citizens of all parties, and the epitaph, stale but true, is, that "the community could have better spared a better man." 


\section{IX \\ CANAL REMINISCENCES}

RECOLLECTIONS OF TRAVEL IN THE OLD DAYS ON THE JAMES RIVER AND KANAWHA CANAL

A MONG my earliest recollections is a trip from A Cumberland County to Lynchburg, in 1835, or thereabouts. As the stage approached Glover's tavern in Appomattox County, sounds as of a cannonade aroused my childish curiosity to a high pitch. I had been reading Parley's History of America, and this must be the noise of actual battle. Yes; the war against the hateful Britishers must have broken out again. Would the stage carry us within range of the cannon balls? Yes, and presently the red-coats would come swarming out of the woods. And-and-General Washington was dead; I was certain of that; what would become of us? I was terribly excited, but afraid to ask questions. Perhaps I was scared. Would they kill an unarmed boy, sitting peacably in a stage coach? Of course they would; Britishers will do anything! Then they will have to shoot a couple of men first-and I squeezed still closer between them.

My relief and my disappointment were equally great, when a casual remark unfolded the fact that the 
noise which so excited me was only the "blasting of rock on the Jeems and Kanawha Canell." What was "blasting of rock?"

What was a "canell?" and, above all, what manner of thing was a "Jeems and Kanawha Canell?" Was it alive?

I think it was; more alive than it has ever been since, except for the first few years after it was opened.

Those were the "good old days" of batteauxpicturesque craft that charmed my young eyes more than all the gondolas of Venice would do now. True, they consumed a week in getting from Lynchburg to Richmond, and ten days in returning against the stream, but what of that? Time was abundant in those days. It was made for slaves, and we had the slaves. A batteau on the water was more than a match for the best four or six horse bell team that ever rolled over the red clay of Bedford, brindle dog and tar-bucket included.

Fleets of these batteaux used to be moored on the river bank near where the depot of the Virginia and Tennessee Railroad now stands; and many years after the "Jeems and Kanawha" was finished, one of them used to haunt the mouth of Blackwater Creek above the toll-bridge, a relic of departed glory. For if ever man gloried in his calling-the negro batteauman was that man. His was a hardy calling, demanding skill, courage and strength in a high degree. I can see him now striding the plank that ran along the gunwale to afford him footing, his long iron-shod pole trailing in the water behind him. Now he turns, and after one or 
two ineffectual efforts to get his pole fixed in the rocky bottom of the river, secures his purchase, adjusts the upper part of the pole to the pad at his shoulder, bends to his task, and the long, but not ungraceful bark mounts the rapids like a seabird breasting the storm. His companion on the other side plies the pole with equal ardor, and between the two the boat bravely surmounts every obstacle, be it rocks, rapids, quicksands, hammocks, what not. A third negro at the stern held the mighty oar that served as a rudder. A stalwart, jolly, courageous set they were, plying the pole all day, hauling in to shore at night under the friendly shade of a mighty sycamore, to rest, to eat, to play the banjo, and to snatch a few hours of profound, blissful sleep.

The up-cargo, consisting of sacks of salt, bags of coffee, barrels of sugar, molasses and whiskey, afforded good pickings. These sturdy fellows lived well, I promise you, and if they stole a little, why, what was their petty thieving compared to the enormous pillage of the modern sugar refiner and the crooked-whiskey distiller? They lived well. Their cook's galley was a little dirt thrown between the ribs of the boat at the stern, with an awning on occasion to keep off the rain, and what they didn't eat wasn't worth eating. Fish of the very best, both salt and fresh, chickens, eggs, milk and the invincible, never-satisfying ash-cake and fried bacon. I see the frying-pan, I smell the meat, the fish, the Rio coffee!-I want the batteau back again, aye! and the brave, light-hearted slave to boot. What did he know about the State debt? There was 


\section{CANAL REMINISCENCES}

no State debt to speak of. Greenbacks? Bless, you! the Farmers Bank of Virginia was living and breathing, and its money was good enough for a king. Readjustment, funding bill, tax-receivable couponswhere were all these worries then? I think if we had known they were coming, we would have stuck to the batteaux and never dammed the river. Why, shad used to run to Lynchburg! The world was merry, buttermilk was abundant; Lynchburg a lad, Richmond a mere youth, and the great "Jeems and Kanawha canell" was going to-oh! it was going to do everything.

This was forty years ago and more, mark you.

In 1838, I made my first trip to Richmond. What visions of grandeur filled my youthful imagination! That eventually I should get to be a man seemed probable, but that I should ever be big enough to live, actually live, in the vast metropolis, was beyond my dreams. For I believed fully that men were proportioned to the size of the cities they lived in. I had seen a man named Hatcher from Cartersville, who was near about the size of the average man in Lynchburg, but as I had never seen Cartersville, I concluded, naturally enough, that Cartersville must be equal in population. Which may be the fact, for I have never yet seen Cartersville, though I have been to Warminster, and once came ncar passing through Bent-Creek.

I went by stage.

It took two days to make the trip, yet no one complained, although there were many Methodist ministers aboard. Bro. Lafferty had not bcen born. I 
thought it simply glorious. There was an unnatural preponderance of preacher to boy-nine of preacher to one of boy. That boy did not take a leading part in the conversation. He looked out of the window, and thought much about Richmond. And what a wonderful world it was! So many trees, such nice rocks, and pretty ruts in the red clay; such glorious taverns, and men with red noses; such splendid horses, a fresh team every ten miles, and an elegant smell of leather, proceeding from the coach, prevailing everywhere as we bowled merrily along. And then the stage horn. Let me not speak of it, lest Thomas and his orchestra hang their heads for very shame. I wish somebody would tell me where we stopped the first night, for I have quite forgotten. Anyhow, it was on the left-hand side coming down, and I rather think on the brow of a little hill. I know we got up mighty soon the next morning.

We drew up at the Eagle Hotel in Richmond. Here again words, and time too, fail me. All the cities on earth packed into one wouldn't look as big and fine to me now as Main Street did then. If things shrink so in the brief space of a lifetime, what would be the general appearance, say of Petersburg, if one should live a million or so of years? This is an interesting question, which you may discuss with yourself, dear reader.

Going northward, I remained a year or two, and on my return the "canell" was finished. I had seen bigger places than Richmond, but had yet to have my first experience of canal travelling. The packet-landing at 


\section{CANAL REMINISCENCES}

the foot of Eighth Street presented a scene of great activity. Passengers on foot and in vehicles continued to arrive up to the moment of starting. I took a peep at the cabin, wondering much how all the passengers were to be accommodated for the night, saw how nicely the baggage was stored away on deck, admired the smart waiters, and picked up a deal of information generally. I became acquainted with the names of Edmond \& Davenport in Richmond, and Boyd, Edmond \& Davenport in Lynchburg, the owners of the packet-line, and thought to myself, "What immensely rich men they must be! Why, these boats cost ten times as much as a stage-coach, and I am told they have them by the dozen."

At last we were off, slowly pushed along under the bridge on Seventh Street; then the horses were hitched; then slowly along till we passed the crowd of boats near the city, until at length, with a lively jerk as the horses fell into a trot, away we went, the cut-water throwing up the spray as we rounded the Penitentiary hill, and the passengers lingering on deck to get a last look at the fair City of Richmond, lighted by the pale rays of the setting sun.

As the shadows deepened, everybody went below. There was always a crowd in those days, but it was a crowd for the most part of our best people, and no one minded it. I was little, and it took little room to accommodate me. Everything seemed as cozy and comfortable as heart could wish. I brought to the tablean excellent one it was-a school-boy's appetite, sharpened by travel, and thought it was "just splendid." 


\section{CANAL REMINISCENCES}

Supper over, the men went on deck to smoke, while the ladies busied themselves with draughts or backgammon, with conversation or with books. But not for long. The curtains which separated the female from the male department were soon drawn, in order that the steward and his aids might make ready the berths. These were three deep, "lower," "middle," and "upper", and great was the desire on the part of the men not to be consigned to the "upper." Being light as cork, I rose naturally to the top, clambering thither by the leathern straps with the agility of a monkey, and enjoying as best I might the trampling overhead whenever we approached a lock. I didn't mind this much, but when the fellow who had snubbed the boat jumped down about four feet, right on my head as it were, it was pretty severe. Still I slept the sleep of youth. We all went to bed early. A few lingered, talking in low tones; the way-passengers, in case there was a crowd, were dumped upon mattresses, placed on the dining-tables.

The lamp shed a dim light over the sleepers, and all went well till some one-and there always was some one-began to snore. Sn-a-a-aw-aw-aw-poof! They would turn uneasily and try to compose themselves to slumber again. No use. Sn-a-a-aw-poof! "Dthat fellow! Chunk him in the ribs, somebody, and make him turn over. Is this thing to go on forever? Gentlemen, are you going to stand this all night? If you are, I am not. I am going to get up and dress. Who is he, anyhow? No gentleman would or could snore in that way!" 
After awhile silence would be restored, and all would drop off to sleep again, except the little fellow in the upper berth, who, lying there, would listen to the trahn-ahn-ahn-ahn of the packet-horn, as we drew nigh the locks. How mournfully it sounded in the night! what a doleful thing it is at best, and how different from the stage-horn, with its cheery, ringing notes! The difference in the horns marks the difference in the two eras of travel; not that the canal period is doleful-I would not say that, but it is less bright than the period of the stage-coach.

To this day you have only to say, within my hearing, trahn-ahn-ahn, to bring back the canal epoch. I can see the whole thing down to the snubbing-post, with its deep grooves which the heavy rope had worn. Indeed, I think I could snub a boat myself, with very little practice, if the man on deck would say "hup!" to the horses at the proper time.

We turned out early in the morning, and had precious little room for dressing. But that was no hardship to me, who had just emerged from a big boardingschool dormitory. Still, I must say, being now a grown and oldish man, that I would not like to live and sleep and dress for twenty or thirty years in the cabin of a canal-packet. The ceremony of ablution was performed in a primitive fashion. There were the tin basins, the big tin dipper with the long wooden handle. I feel it vibrating in the water now, and the water a little muddy generally; and there were the towels, a big one on a roller, and the little ones in a pile, and all of them wet. These were discomforts, it is true, but, 
pshaw! one good, big, long, deep draught of pure, fresh morning air-one glimpse of the roseate flush above the wooded hills of the James, one look at the dew besprent bushes and vines along the canal bank -one sweet caress of dear mother nature in her morning robes, made ample compensation for them all. Breakfast was soon served, and all the more enjoyed in consequence of an hour's fasting on deck; the sun came out in all his splendor; the day was fairly set in, and with it there was abundant leisure to enjoy the scenery, that grew more and more captivating as we rose, lock after lock, into the rock-bound eminences of the upper James. This scenery I will not attempt to describe, for time has sadly dimmed it in my recollection. The wealth of the lowlands, and the upland beauty must be seen as I have seen them, in the day of their prime, to be enjoyed.

The perfect cultivation, the abundance, the elegance, the ducal splendor, one might almost say, of the great estates that lay along the canal in the old days have passed away in a great measure. Here were gentlemen, not merely refined and educated, fitted to display a royal hospitality and to devote their leisure to the study of the art and practice of government, but they were great and greatly successful farmers as well. The land teemed with all manner of products, cereals, fruits, what not! negroes by the hundreds and the thousands, under wise directions, gentle but firm control, plied the hoe to good purpose. There was enough and to spare for all-to spare? aye! to bestow with glad and lavish hospitality. A mighty change has 


\section{CANAL REMINISCENCES}

been wrought. What that change is in all of its effects mine eyes have happily been spared the seeing; but well I remember-I can never forget-how from time to time the boat would stop at one of these estates, and the planter, his wife, his daughters, and the guests that were going home with him, would be met by those who had remained behind, and how joyous the greetings were! It was a bright and happy scene, and it continually repeated itself as we went onward.

In fine summer weather, the passengers, male and female, stayed most of the time on deck, where there was a great deal to interest, and naught to mar the happincss, except the oft-repeated warning, "braidge!" "low braidge!" No well-regulated packet-hand was ever allowed to say plain "bridge"; that was an etymological crime in canal ethics. For the men, this on-deck existence was especially delightful; it is sueh a comfort to spit plump into the water without the trouble of feeling around with your head, in the midst of a political discussion, for the spittoon.

As for me, I often went below, to devour Dickens's earlier novels, which were then appearing in rapid succession. But, drawn by the charm of the scenery, I would often drop my book and go back on deck again. There was an islet in the river-where, exactly, I cannot tell-which had a beauty of its own for me, because from the moment I first saw it, my purpose was to make it the scene of a romance, when I got to be a great big man, old enough to write for the papers. There is a point at which the passengers would get off, and taking a near cut across the hills, would 239 
stretch their legs with a mile or two of walking. It was unmanly, I held, to miss that. Apropos of scenery, I must not forget the haunted house near Manchester, which was pointed out soon after we left Richmond, and filled me with awe; for though I said I did not believe in ghosts, I did. The ruined mill, a mile or two farther on, was always an object of melancholy interest to me; and of all the locks from Lynchburg down, the Three-Mile Lock pleased me most. It is a pretty place, as every one will own on seeing it. It was so clean and green, and white and thrifty-looking. To me it was simply beautiful. I wanted to live there; I ought to have lived there. I was built for a lockkeeper-have that exact moral and mental shape. $\mathrm{Ah}$ ! to own your own negro, who would do all the drudgery of opening the gates. Occasionally you would go through the form of putting your shoulder to the huge wooden levers, if that is what they call them, by which the gates are opened; to own your own negro and live and die calmly at a lock! What more could the soul ask? I do think that the finest picture extant of peace and contentment-a little abnormal, perhaps, in the position of the animal-is that of a sick mule looking out of the window of a canal freightboat. And that you could see every day from the porch of your cottage, if you lived at a lock, owned your own negro, and there was no great rush of business on the canal, (and there seldom was), on the "Jeems and Kanawhy," as old Capt. Sam Wyatt always called it, leaving out the word "canal," for that was understood. Yes, one ought to live as a pure and 
resigned lock-keeper, if one would be blest, really blest.

Now that I am on the back track, let me add that, however bold and picturesque the cliffs and bluffs near Lynchburg and beyond, there was nothing from one end of the canal to the other to compare with the first sight of Richmond, when, rounding a corner not far from Hollywood, it burst full upon the vision, its capitol, its spires, its happy homes, flushed with the red glow of evening. And what it looked to be, it was. Its interior, far from belieing its exterior, surpassed it. The world over, there is no lovelier site for a city; and the world over there was no city that quite equalled it in the charm of its hospitality, its refinement, its intelligence, its cordial welcome to strangers. Few of its inhabitants were very rich, fewer still were very poor. But I must not dwell on this. Beautiful city! beautiful city! you may grow to be as populous as London, and surely no one wishes you greater prosperity than I; but grow as you may, you can never be happier than you were in the days whereof I speak. How your picture comes back to me, softened by time, glorified by all the tender, glowing tints of memory. Around you now is the added glory of history, a defence almost unrivalled in the annals of warfare; but for me there is something even brighter than historic fame, a hue derived only from the heaven of memory. In my childhood, when all things were beautiful by the unclouded light of "the young soul wandering here in nature," I saw you in your youth, full of hope, full of promise, full of all those gracious influences which 


\section{CANAL REMINISCENCES}

made your State greatest among all her sisters, and which seemed concentrated in yourself. Be your maturity what it may, it can never be brighter than this.

To return to the boat. All the scenery in the world - rocks that Salvator would love to paint, and skies that Claude could never limn-all the facilities for spitting that earth affords, avail not to keep a Virginian away from a julep on a hot summer day. From time to time he would descend from the deck of the packet and refresh himself. The bar was small, but vigorous and healthy. I was then in the lemonade stage of boyhood, and it was not until many years afterward that I rose through porterees and claretpunches to the sublimity of the sherry cobbler, and discovered that the packet bar supplied genuine Havana cigars at fourpence-ha'penny. Why, eggs were but sixpence a dozen on the canal bank, and the national debt wouldn't have filled a teacup. Internal revenue was unknown; the coupons receivable for taxes inconceivable, and forcible readjustment a thing undreamt of in Virginian philosophy. Mr. Mallock's pregnant question, "Is life worth living?" was answered very satisfactorily, methought, as I watched the Virginians at their juleps: "Gentlemen, your very good health"; "Colonel, my respects to you"; "My regards, Judge. When shall I see you again at my house? Can't you stop now and stay a little while, if it is only a week or two?" "Sam," (to the barkeeper), "duplicate these drinks."

How they smacked their lips ' how hot the talk on 
politics became; and how pernicious this example of drinking in public was to the boy who looked on! $\mathrm{Oh}$ ! yes; and if you expect your son to go through life without bad examples set him by his elders in a thousand ways, you must take him to another sphere. Still, the fewer bad examples the better, and you, at least, need not set them.

Travelling always with my father, who was a merchant, it was natural that I should become acquainted with merchants. But I remember very few of them. Mr. Daniel H. London, who was a character, and Mr. Fleming James, who often visited his estate in Roanoke, and was more of a character than London, I recall quite vividly. I remember, too, Mr. Francis B. Deane, who was always talking about Mobjack Bay, and who was yet to build the Langhorne Foundry in Lynchburg. I thought if I could just see Mobjack Bay, I would be happy. According to Mr. Deane, and I agreed with him, there ought by this time to have been a great city on Mobjack Bay. I saw Mobjack Bay last summer, and was happy. Any man who goes to Gloucester will be happy. More marked than all of these characters was Major Yancey, of Buckingham, "the wheel-horse of Democracy," he was called; Tim. Rives, of Prince George, whose face, some said, resembled the inside of a gunlock, being the war-horse. Major Yancey's stout figure, florid facc, and animated, forcible manner, come back with some distinctness; and there are other forms, but they are merely outlines barely discernible. So pass away men who, in their day, were names and powers-shadows gone into 
shadowland, leaving but a dim print upon a few brains, which in time will soon flit away.

Arrived in Lynchburg, the effect of the canal was soon seen in the array of freight-boats, the activity and bustle at the packet landing. New names and new faces, from the canal region of New York, most likely, were seen and heard. I became acquainted with the family of Captain Huntley, who commanded one of the boats, and was for some years quite intimate with his pretty daughters, Lizzie, Harriet, and Emma. Captain Huntley lived on Church Street, next door to the Reformed, or as it was then called, the Radical Methodist Church, and nearly opposite to Mr. Peleg Seabury. He was for a time connected in some way with the Exchange Hotel, but removed with his family to Cincinnati, since when I have never but once heard of them. Where are they all, I wonder? Then, there was a Mr. Watson, who lived with Boyd, Edmond \& Davenport, married first a Miss - , and afterward, Mrs. Christian, went into the tobacco business in Brooklyn, then disappeared, leaving no trace, not the slightest. Then there was a rare fellow, Charles Buckley, who lived in the same store with Watson, had a fine voice, and, without a particle of religion in the ordinary sense, loved dearly to sing at revivals. I went with him; we took back seats, and sang with great fervor. This was at night. Besides Captain Huntley, I remember among the captains of a later date, Capt. Jack Yeatman; and at a date still later his brother, Capt. C. E. Yeatman, both of whom are still living. There was still another captain whose name was 
Love_ something, a very handsome man; and these are all.

In 1849, having graduated in Philadelphia, I made one of my last through-trips on the canal, the happy owner of a diploma in a green-tin case, and the utterly miserable possessor of a dyspepsia which threatened my life. I enjoyed the night on deck, sick as I was. The owl's "long hoot," the "plaintive cry of the whippoorwill"; the melody-for it is by association a melody, which the Greeks have but travestied with their brek-ke-ex, ko-ex-of the frogs, the mingled hum of insect life, the "stilly sound" of inanimate nature, the soft respiration of sleeping earth, and above all, the ineffable glory of the stars. Oh! heaven of heavens, into which the sick boy, lying alone on deck, then looked, has thy charm fled, too, with so many other charms? Have thirty years of suffering, of thought, of book-reading, brought only the unconsoling knowledge, that yonder twinkling sparks of far-off fire are not lamps that light the portals of the palace of the King and Father, but suns like our sun, surrounded by earths full of woe and doubt like our own; and that heaven, if heaven there be, is not in the sky; not in space, vast as it is; not in time, endless though it bewhere then? "Near thee, in thy heart!" Who feels this, who will say this of himself? Away, thou grayhaired, sunken-cheeked sceptic, away! Come back to me, come back to me, wan youth; there on that deck, with the treasure of thy faith, thy trust in men, thy worship of womankind, thy hope, that sickness could not chill, in the sweet possibilities of life. Come back to me! 
-'Tis a vain cry. The youth lies there on the packet's deck, looking upward to the stars, and he will not return.

The trip in 1849 was a dreary one until there came aboard a dear lady friend of mine who had recently been married. I had not had a good honest talk with a girl for eighteen solid-I think I had better say long, (we always say long when speaking of the war)-_"fo' long years!"-I have heard it a thousand times-for eighteen long months, and you may imagine how I enjoyed the conversation with my friend. She wasn't very pretty, and her husband was a Louisa man; but her talk, full of good heart and good sense, put new life into me. One other through-trip, the very last, I made in 1851 . On my return in 1853 , I went by rail as far as Farmville, and thence by stage to Lynchburg; so that, for purposes of through travel, the canal lasted, one may say, only ten or a dozen years. And now the canal, after a fair and costly trial, is to give place to the rail, and I, in common with the great body of Virginians, am heartily glad of it. It has served its purpose well enough, perhaps, for its day and generation. The world has passed by it, as it has passed by slavery. Henceforth Virginia must prove her metal in the front of steam, electricity, and possibly mightier forces still. If she can't hold her own in their presence, she must go under. I believe she will hold her own; these very forces will help her. The dream of the great canal to the Ohio, with its nine-mile tunnel, costing fifty or more millions, furnished by the general government, and revolutionizing the commerce of the United States, much as the discovery of America and opening of the 
Suez Canal revolutionized the commerce of the world, must be abandoned along with other dreams.

One cannot withhold admiration from President Johnston and other officers of the canal, who made such a manful struggle to save it. But who can war against the elements? Nature herself, imitating man, seems to have taken special delight in kicking the canal after it was down. So it must go. Well, let it go. It knew Virginia in her palmiest days and it crushed the stage coach; isn't that glory enough? I think it is. But I can't help feeling sorry for the bullfrogs; there must be a good many of them between here and Lexington. What will become of them, I wonder? They will follow their predecessors, the batteaux; and their pale, green ghosts, seated on the prows of shadowy barges, will be heard piping the roundelays of long-departed joys.

Farewell canal, frogs, musk-rats, mules, packethorns and all, a long farewell. Welcome the rail along the winding valley of the James. Wake up, Fluvanna! Arise, old Buckingham! Exalt thyself, $\mathrm{O}$ Goochland! And thou, O Powhatan, be not afraid nor shame-faced any longer, but raise thy Ebenezer freely, for the day of thy redemption is at liand. Willis J. Dance shall rejoice; yea, Wm. Pope Dabney shall be exceeding glad. And all hail our long-lost brother! come to these empty, aching arms, dear Lynch's Ferry.

I have always thought that the unnatural separation between Lynchburg and Richmond was the source of all our troubles. In some way, not entirely clear to me, it brought on the late war, and it will bring on 
another, if a reunion between the two cities does not soon take place. Baltimore, that pretty and attractive, but meddlesome vixen, is at the bottom of it all. Richmond will not fear Baltimore after the rails are laid. Her prosperity will date anew from the time of her iron wedding with Lynchburg. We shall see her merchants on our streets again, and see them often. That will be a better day.

Alas! there are many we shall not see. John G. Meem, Samuel McCorkle, John Robin McDaniel, John Hollins, Charles Phelps, John R. D. Payne, Jehu Williams, Ambrose Rucker, Wilson P. Byrant (who died the other day), and many, many others, will not come to Richmond any more. They are gone. And if they came, they would not meet the men they used to meet; very few of them at least. Jacquelin P. Taylor, John N. Gordon, Thomas R. Price, Lewis D. Crenshaw, James Dunlop-why add to the list? They too are gone.

But the sons of the old-time merchants of Lynchburg will meet here the sons of the old-time merchants of Richmond, and the meeting of the two, the mingling of the waters-Blackwater creek with Bacon Quarter branch-deuce take it! I have gone off on the water line again - the admixture, I should say, of the sills of Campbell with the spikes of Henrico, the readjustment, so to speak, of the ties (railroad ties) that bind us, will more than atone for the obsolete canal, and draw us all the closer by reason of our long separation and estrangement. Richmond and Lynchburg united will go onward and upward in a common career of 


\section{CANAL REMINISCENCES}

glory and prosperity. And is there, can there be, a Virginian, deserving the name, who would envy that glory, or for a moment retard that prosperity? Not one, I am sure.

Allow me, now that my reminiscences are ended, allow me, as an old stager and packet-horn reverer, one last Parthian shot. It is this: If the James River does not behave better hereafter than it has done of late, the railroad will have to be suspended in midheavens by means of a series of stationary balloons; travelling then may be a little wabbly, but at all events, it won't be wet. 


\section{$\mathrm{X}$}

\section{THE SACRED FURNITURE WAREROOMS}

THE stranger in Lynchburg who stops at the City 1 Hotel, in passing to and fro, will not fail to be struck with the singular aspect of a building not far from his lodgings. Upon the front of this building, which stands a little back from the house-line of the street, he will find marked-

“E. J. FOLKES,

\section{FURNITURE WAREROOMS."}

The shape of the house so marked is unlike the shape of houses appropriated to business purposes; but what will most curiously attract the stranger's eye, is a little belfry perched above the gable. No bell swings in that belfry. Under a hastily-made shed-porch in front of the house will be found a number of rocking-chairs, tables, and other articles, showing what may be expected inside. In the sweet summer mornings, the proprietor may not infrequently be seen seated in one of his rocking-chairs, quietly reading a newspaper.

If the stranger will venture to open either of the two folding doors that give ingress to this building, he will find the interior filled to repletion with all manner of 250 
furniture. Let him go boldly in among the multitude of bureaus, sofas, wash-stands, pier-tables, and lounges. All is very still there. The bright and glossy crowd of dumb domestics are patiently awaiting owners to come and claim them. One is reminded of those Northern intelligence offices, where hosts of Irish and German girls sit, without speaking, day after day; only here the servants are not flesh and blood, but structures of rosewood, mahogany, and marble.

A strange and not wholly pleasant feeling creeps over the visitor as he gazes on the inanimate forms that people the broad wareroom.

If this furniture had been used, if it were old, and black, and rickety, the feeling should be desolate indeed. But now that it is new, and rich, and beautiful, it should suggest cheerful fancies only. Hither the young couples will come to furnish their house-their home-sweet, because it is theirs. In yonder tall wardrobe will hang the spotless white dresses of the bride, and the brave black finery of the groom. The glass on that marble-topped bureau will reflect the blushes of her pure young face, and the drawers will be proud to hold the delicate laces and the manifold "nice nothings" that pertain to her in right of her sex. Upon that gold-embroidered tête-à-tête, the happy pair will tell each other the story of their lovedays-again and again-tiring never of that sweet time when the breeze blew fresh and fragrant from the ever-nearing Isle of Hope. Surely the dumb furniture is eloquent, and tells charming stories!

Nevertheless, to the visitor, meditating in the midst 
of the wareroom, there comes through all the meshes of his silver-woven fancies, a something, out of keeping with the place, breathing awe upon him.

What is this? and why comes it?

It is the nameless spirit that clings to and lingers in and around every unpeopled habitation; and it comes here with peculiar solemnity and power because this wareroom was once the tabernacle and house of the Most High God! Yea, it was even so; and albeit the pulpit hung with green, the old-fashioned plain benches, and the deep-toned bell are gone, the stranger may still see that this was a church once. Here the mysterious rites that conjoin the transient mortal with the Source infinite and eternal of life, were performed. Here religion, in its terror and its tenderness, in the sublimity of its hopes and the boundlessness of its despair, was preached by lips fired almost to prophecy; here prayers as pure as ever trembled up to God's throne were uttered; and here repentance as sincere as ever transformed erring men was felt and avowed. Can a soul know its unseen tragedies in time and place, and leave no mute record there? Can the glow and the joy of a faith that dulls the last sharp pang, and triumphs over decay be felt, and the spot that saw the birth of that faith bear no witness of it? Can celestial ministers bring messages of everlasting peace to the fear-harrowed soul, and no lingering trace, perceptible to the finer senses, remain upon the walls hallowed by the touches of their wings, and on the floor pressed once by their noiseless sandals? Nay, truly. If the fireside delights, and all the "fair humanities" 
that endear the humblest dwelling, will cluster about the broken hearthstone, and redeem with tenderest suggestions the horror of the charred and fallen rafters, how much more shall the higher emotions of religion hallow holier places, and with greater tenacity cling to ruined shrines and deserted churches!

But the palpable awe of the sacred wareroom must be vague and fleeting to the stranger. It is deep, it is lasting to him who remembers the old church in its prime. When the white palings in front enclosed a little yard, green with a patch of sward on either side, and a little paper-mulberry tree in the centre of each patch. When the bell, tolling early on a bright Sunday morning, summoned the children, clean with starched white clothes, to the Sabbath-school. When the mind, fretted now and hardened with business cares, was concerned about the questions of the catechism, and the ear familiar with the getting-by-heart hum of the hundred round-faced scholars.

Graver was the time when the morning service came. The little yard was filled then with gentlemen grouped about the mulberry tree, after they had assisted the ladies in to the right-hand door. Youths were there, arrayed in their best, watching the fair faces and the charming figures as they came walking, or tripped lightly out of carriages.

Within all was hushed. The scholars, who shortwhile hummed so loudly, were silent now, and sat demurely by their parents' sides, with restless feet that could not touch the floor. Soon, overcome with heat, the little forms would be stretched upon the 
bench, the moist young brows, protected by a kindly handkerchief, reposing in a father's or a mother's lap.

Alas! they who slept sweet slumbers in the happy day when this wareroom was a church, shall sleep thus again no more. The hands whose gentle touches waked those sleepers when the sermon ended, have mouldered into dust, or tremble now with the palsy of age. The flight of years has made men and women of those children who in this wareroom first heard the public accents of prayer and praise. Their youth is gone, and with it the wonder and the beauty of life, and almost of religion.

Memories still more solemn come to him who once sat in this sanctuary-memories of high religious festivals and revivals, with their excitement, their power, their terror, with that wondrous fascination which the sight of weeping men and women, repenting, and heart-broken, and joyful, must ever give.

But sadder yet, and sweeter than these, come memories imbued with the intense and mysterious charm of sacred music.

Ah! the singers, the singers that sang in this old church! Few, very few of them remain. Some sing no longer; some have wandered from the fold; some live in far States and in other cities; and some-are sleeping.

One noble old man, whose fine, venerable head kept time to the divine music in his heart, we all remember. Warm was he; true, upright, full of love toward his fellow-man, full of service to his Master, and not to be 
wearied in well-doing. Who that ever heard him can forget with what fervor he was wont to sing:

\section{'All hail the power of Jesus name, Let angels prostrate fall; Bring forth the royal diadem, And crown Him Lord of all."}

lending his whole soul to the melodious utterance of that name he loved so well?

His earthly voice fell silent long ago; his honored dust reposes in the graveyard of his church; and there a marble obelisk rises to attest the esteem his townsmen justly bore him.

One other singer, the sweetest that ever sang in this old church, returns dim but beautiful to the filling eyes that gaze upon the dead space where once her living self-lovely in the dawn of womanhood and in the beauty of her guilelessness-sang praises to Him who is the source of beauty and of truth. How pure, how sweet, how tender, was her voice! the vocal life of her sinless heart! the fit, intelligent, worshipful, loving instrument to hymn the highest music!

Unhappy, unhappy singer! Neither thy beauty, nor thy sweetness, nor thy sinlessness, could save thee from the appointed sorrow. It is over now. The sweet voice is dumb, the loveful lips are ashes, and the true, stainless woman's heart shall throb no more, no more for ever. All of her that could fade lies in the churchyard, not far from him, the noble Christian father and friend of humanity, whose voice often blended with her own sweet tones when on earth they sang together the 


\section{THE SACRED FURNITURE WAREROOMS}

songs of Zion. Over her, the leaves, dark and glossygreen, of the sombre oaks have lightly moved to the sighing winds of many vernal morns; and upon her tomb, through the long nights of many autumns, those leaves, grown sere, have fallen fast, as tears to weep her mournful fate. Peace be to her, and joy, and love! Other singers there were in this old church, and others still who sang only in their hearts; all worthy to be named, and all too sadly well remembered and recalled by those who see the bowed forms, clad in deep crape, that tremblingly walk the aisles of the new church, and who miss the reverent faces from their accustomed pew, and hear no more the well-known voices in the choir.

Alas! for life's changes; alas! for those that have already come; and for those yet to come-unknown changes-but which must come-oh! how shall we bear them?

The new times demanded the new church; its gothic beauty deserves the admiration it has received; its organ, touched by a master's hand, doth utter forth a glorious voice; but so long as one beam of the old church is fastened to another, and so long as memory holds her seat, so long there will be one who will turn from the finer architecture of the modern structure and forget the grander music of the organ, to muse over the simpler manners of the past, and to bring back the plain hymn-music and the singers that sang it of old, in the Sacred Furniture Warerooms. 


\title{
$\mathrm{XI}$ \\ MY VILE BEARD
}

\author{
I \\ GETTING SHAVED IN CHARLOTTE
}

I HAVEN'T got much beard, but what little there is 1 of it is the worst kind of beard. In the first place, it is more like Berlin wire, tough and hard, than an animal or other substance.

Some people, you know, contend that the hair and nails are vegetables, inasmuch as they continue to grow after a body is dead. But my beard is a metal. In the next place, my beard crops out at all sorts of angles, that on my chin growing downward, like anybody else's, while that on my cheeks grows upward, and that on my throat emerges sideways in every direction, like the rays of a starfish. Lastly, my skin is exceedingly tender, my jaws very hollow, and my neck scraggy and fluted, like a consumptive Corinthian column-if you can imagine such a thing. The consequence is that I can't shave myself, even if I knew how to sharpen a razor, a feat which I have often attempted, and shall never perform. That's certain, for I've tricd and tried, till there is no use in trying. In- 
deed, it is impossible for a barber to shave me clean. You see, he can't get at my beard, and if he could, he dare not shave both ways, for if he does he leaves my face as bloody as a black-heart cherry, just skinned.

Leander Harrison, the best barber in the State, according to my thinking, will tell you that my beard is the worst beard that ever disfigured the human visage.

How serious a thing it is not to be able to shave myself you will be able to understand as soon as I tell you how I got shaved in Charlotte. Listen: In the year 1850 or 1851 - the date is not important-I started from town-what town?-on horsebackwhose horse's back? If you had seen my horse, you would at once have detected my business. He was a showy horse, and his trappings, down to the very martingale, were spick and span new. Saddle-bags were new, and full of new clothes. Umbrella was new, hat new, gloves new, whip new-in fact, the whole turnout, rider included, had that slick varnished look that things have when fresh from the hands of the cabinet-maker. I was five and twenty years old, and the summer was just closing. Surely you must guess that, although I was not going north, my object was to lay in a stock of dry goods for the fall.

The day was fine. I had a plenty of excellent cigars, and never felt better in my life.

Our appearance ("our" meaning the horse and myself) attracted the attention of everybody we passed. We were especially pleased with the compliment passed upon us by one of a group of small negroes, who as- 
sembled around us when we stopped at a woe-begone house on the roadside to get a drink of water. The compliment ran thus: "Unh! if dat ar ain't de pootyest white man and de pootyest hoss and bridle, I wisht I may nuvver." Under the impulse of this praise we struck off gaily into that lonesome road that leads to the particular locality in the County of Charlotte which was the goal of my ambition. For twenty miles we passed not a solitary traveller, and scarcely a human habitation.

I recall only a single log-hut on the left-hand side of the road. Some two score sickly tobacco plants erowded up to the very door of this hut, showing that it was inhabited; but not a living thing was visible.

Fifty yards down the road I overtook a draggletailed rooster, who ran out of my way and hid behind a chestnut tree, and set up a crow in the weak accents of unmistakable bronchitis. My horse switched his tail as if to resent the insult, and on we went along the lonely road. I began to feel not so comfortable in the saddle as I had been at starting, and my high spirits abated. As I had never been in that region before, it soon became very eertain that my invariable rule of getting lost had not been broken. But there was the "main, plain road," and all I had to do was to follow it. So I followed it. And the trot of the showy horse became harder and harder. Nothing but the everdelightful and continually recurring reverie, in which I had been indulging from the moment I set out, sustained me while that showy horse trotted harder and still harder along that dreary road through the inter- 
minable chestnut woods. All at once I was rudely awakened from my delicious day-dream. The horse had stopped; and this is what made him stop:

\section{enterTanement \\ By reusin b Riles}

This sign, painted in white letters on a black ground, was fastened by a wooden pin, driven through its centre, into an augur hole in an immense hewn gate-post. There was one post, and no fence at all, only a horserack, made of a piece of cedar, with its many branches trimmed off, laid upon two forked uprights of Spanish oak. The house had been a large and a good one. Now it was far gone in dark decay, as were also the few remaining out-houses. All the old trees had died out; one side of the large yard contained a thicket of young locusts, while the other was unshaded, and almost grassless.

I thought to myself that Mr. Briles's entertainment was likely to be rather indifferent. Still, it was the best I could do. So, seeing nobody, I sang out, after the English fashion-

"House!"

No answer.

"House!"

Not a word.

"HOUSE!"- this time as loud as I could bawl. To my surprise I was answered from behind. " "Tain't 'house,' 'tis Briles." 


\section{MY VILE BEARD}

"Ah!" said I, turning around, "how do you do, sir?" "Right peart; how'd y' come on yourself ?"

The speaker was a fine specimen of a Virginia countryman; over six feet, bony, dark, athletic, but lazy, good-natured, yet passionate, and clad only in a coarse shirt and still coarser "bluein" pantaloons.

"What place is this?" I asked.

"Brileses."

"And where is Mr. Briles?"

"Wharuvver he is thar you'll find me."

"Well, Mr. Briles, can I get dinner?"

“Sertney you kin. We all done dinner mo'n two hours, and I was jes goin' squrl huntin'; but the leaves is too thick yet awhile, and thar's plenty a time befo' sundown. I recon we can git you up somethin' or nuther pretty quick that'll do to stay your stummuck. Boy!"

"Boy" was uttered in a tone calculated to raise the dead, and very soon a cornfield hand came running to take my horse. Dismounting slowly, I found myself so sore from the trotting I had undergone that I could hardly walk into the house, the inside of which I will not describe, lest it make this story too long. Suffice it to say, that it corresponded with the outside. Depositing my bran new saddle-bags on the bench-it was mighty hard-in the porch, I sat down and took off my hat and cravat, the better to cool off.

"'Take somethin', Mister?"

“With great pleasure," I replied.

“"'Tain't so dog-goned good, but you're 'bundant welcome to it. Spos'n I make you a julep?" 


\section{MY VILE BEARD}

"Very well," said I.

A julep of new whiskey, with brown sugar, and without ice is rather a hard thing to worry down, but I was so exhausted that I really enjoyed it. After I had finished it, I asked Briles: "What county is this?"

"Tcharlut."

"What?"

"Tcharlut; the County uv Tcharlut."

"Oh! Charlotte."

"Yes; Tcharlut."

"Well, how far is it from here to the court house?"

"A little over twenty-one miles-jest twenty-one mile to a nit's night-cap from that ar big white oak up yonder at the forks uv the road."

"And what is this part of the country called? Has it any particular name?"

“'To be sho'. Right here is Brileses, which it is a presink; but this here ridge ar called 'Venjunce Ridge.' ',

"Indeed! Why so?"

"They was bleest to name it somethin', I reckon, and that's what it took its name from."

"Ah! IVell, does a gentleman named Cooke live anywhere in this neighborhood?"

“'Thar's old Beazly Cooke keeps a wheelwright shop up here about two miles down in the Cub Creek Hollow."

"He is not the man."

“Thar's Jonceston Cooke, owns 'bout two hundred niggers, on the river." 
"No; it is not he."

"Oh!" he exclaimed, with the most inoffensive impertinence. "Oh! I seen your hand plain-two bullets and a bragger-a queen by the livins! It's the ole captain you mean. I might a' known you was arter courtin somethin'. He's rich as mornin's milk." "Why, you don't expect me to court him??"

“Yes, maybe I don't. Ef he didn't had them thousand acres o' low groun's that ar bridle and saddle would nuvver have stopped at Brileses."

"Well," said I, "if you will turn a city collector into a courting man, I can't help it."

"Pretty clecking you'll do, I jes bet. You'll cleckt a hundred and twenty poun' uv lady-meat and about thirty niggers, or else you'll cleckt a kicking; one or tuther, sertin."

All this was said in such an indescribably goodnatured, honest tone, that I could not take offence. So I told Briles that I would take a nap until dinner was ready.

In what appeared to me a half minute, but was in fact half an hour, I was awakened by Briles, and told that dinner was on the table. A small table, covered with a dingy cloth, was placed in the middle of the dining-room, and thereon I found chicken, ham and, eggs, some sweet potatoes and butter-beans. In addition to these, there was a plate of good butter, a pitcher of milk, and three large hoe-cakes. This was the dinner. Affixed to the ceiling, just over the table, I perceived one of those fixtures which years ago used to be in vogue in much larger taverns, called, I believe, 


\section{MY VILE BEARD}

a fan. It consisted of a long piece of red cloth, suspended by mechanical contrivances which I cannot describe, and was kept in motion by means of a rope pulled by a negro boy, who stood exactly in the centre of the fire-place. As I sat down, the boy began to pull the fan with vigor.

Briles apologized for his dinner. "It's pritty po' eatin', and if you jest had waited tel supper time, I'd a had you some squrls. We kill a ram lam' yistiddy, the finest you uvver see, fat two inches thick on the ribs, but the nigger took and put it in the spring house, thout fastnin' the do,' and the fust thing a ole houn' sneak in thar and eat it up clean to the bone." During these remarks, Briles once or twice interrupted himself to say in a loud voice, "boy!" to which the negro pulling the fan would answer "suh,", and pull the fan more vigorously than before. Then Briles would go on with what he had to say. But he was evidently annoyed about something.

"Of co'se the dog didn't eat——"

"Boy!"

"Suh."

The fan fluttered faster.

"Didn't eat all the lam', because_—"

"Boy!"

"Suh."

The fan flapped still faster.

"Because we all had done sent a good part of it away to vayus neighbors__"

"Boy!"

"Suh." 
The fan was going at a terrific rate. Briles thundered out-

"Boy! don't be so dam' induschus!" Never was a negro so taken aback. He had supposed all the time, that the object of his master in calling him was to urge him on in the work of keeping off the flies with the fan, and now, when he discovered his mistake, I don't think the whole County of "Tcharlut" could have presented a more pitiably chop-fallen spectacle. I laughed outright. But Briles glared at him savagely, until I thought he would have fallen where he stood.

When dinner was over, the master of the house invited me to go out hunting with him, a proposition to which I would willingly have acceded, if I had not been so stiff and sore. Briles went off. I lighted my cigar and lolled upon the bench in the porch. I pass over the night and the particulars of my introduction to Mrs. Briles, who proved to be both ugly and quarrelsome-for which last Briles, very confidingly, accounted, by saying "there nuvver was no peace in no family that didn't have children."

The next morning I found myself even more stiff and sore than I had been the evening previous. Every joint ached. It was plain that $I$ had to pass the day at Briles's. Briles did his best to make my stay agreeable, but the constant sharp voice of Mrs. Briles, as she scolded the negroes in the back yard, and my natural impatience to reach my journey's end, made all his efforts abortive.

However, the second morning came and found me, not exactly supple, but able to mount the trotting265 
horse again, and to endure him for a season. I determined to hasten on immediately after breakfast. But when I went to the little dingy-looking glass to brush my hair, a terrible fact was revealed to me: My beard was three days old! Shave I must, and that immediately; but I could not shave myself. I had no razor. Strange that I had never thought of that before leaving town. But somebody must shave me. Who? There were no barbers in that country; it was doubtful whether Briles ever shaved at all; and what to do I knew not. The case, as it appeared to me at this time, was so grave that I find it impossible to impart it. I was young, was going to a highly respectable house, on business of the utmost importance. It was indispensable to a good first impression that my appearance should at least be decent. As these reflections crowded upon me, I made up my mind to return to town, get shaved, and bring a barber back with me.

When I went down to breakfast I told Briles of my unhappy condition. Sympathizing with me, he said he "wished to goodness he could shave me, but he couldn't. He could trim ha'r tollibly, but never had laid no razor to no man's jaw but his own." After thinking over the matter for some time, it suddenly occurred to him that his man "Benj'min" had worked on the "Cunnel," and may be he knew how to shave. So Benj'min was called. He proved to be a clumsy, self-important creature, who "'low'd he could shave a gent'man good as any barber." Rather than ride back thirty miles to town, I consented to let Benjamin try 
his hand on me, upon the following terms, proposed by himself:

1. He didn't want me to pay him nuthin no way.

2. If he "made the bleed come," he "wouldn't take nuthin if I was to gin it to him."

3. He agreed to shave me "two days under the skin."

4. If I had "a little ole wescut or hankcher," Benjamin would be a thousand times "obleeged" to me for either of them.

This contract being accepted on my part, Briles went off to a "vandue," and Benjamin went off after his shaving implements. I waited in moody silence his return.

Soon I heard Mrs. Briles quarrelling with Benjamin because he attempted to take some of the cook's hot water, and thought something was said about "soap," but of this last I was not certain. I waited and waited. It was fully an hour before Benjamin came back. In one hand he held a tin bucket, such as negroes use to carry their dinner to the field, full of hot water; in the other was a large, round, dark-bay, ugly-looking gourd; and under his arm was what appeared to me to be a leather surcingle, a mop, and a bowie-knife; but I was so mad with him on account of his delay that $I$ could not see very well. He came into the porch, where I sat, with a smile of intense self-esteem on his face, and said he had been detained all this time by honing the razor. I answered not a word. Setting down his implements on the bench behind me, he stood irresolute for a time, and finally went off. I sat still as a stone. He soon returned with an axe and a 
nail. Driving the nail partway into one of the pillars of the porch, he bent the head upward so as to form a hook, and to this hook he attached the leather surcingle (it was over a yard long), and began to "strop" the bowie-knife, which proved, however, to be a razor, or rather a cross between a razor and a broad-axe. Never before or since have I seen such an implement.

I looked on, without saying a word. He talked and strapped, and strapped and talked. When he had finished strapping his broad-axe (it took him a quarter of an hour to do so), he tested its sharpness by nicking his thumb-nail and by splitting a thread of his wool. I kept perfectly quiet. Regarding myself as a doomed man, I sat quite passive and ready to meet my fate. He laid down his razor and went behind me to get the tin-bucket and other things. I have had many sensations in my time, but I doubt if all of them put together could produce quite so harrowing a state of mind and body as I experienced when that negro came forward with a large painter's brush (it was not a mop), and a gourd full of soft soap-this home-made, greasy, villainous stuff. But I held my peace. He lathered me. Ugh! I shudder when I think of it. But he did lather me up to my very temples and down to my breast-bone. And such lather! Whew! I opened not my mouth. Nay, verily-not in the presence of that lather. After he had invested my countenance with the nauseous froth, Benjamin gave his baby broad-axe a few more whets on the surcingle, and the amputation of my beard commenced. During the first few strokes I was agreeably surprised, the broad- 


\section{MY VILE BEARD}

axe seemed to cut so smoothly. But when he had scraped my jaws pretty thoroughly and got over to the fluted part of my neck, where the beard grew like the vortex of a whirlpool, I became conscious of a pain that no man-certainly no woman-ever realized. I cannot describe it. It was like tearing the skin off and sticking of red-hot needles into the raw meat, as fast as it appeared under the razor. But it was something more than this-something more than the dumb rage I felt, added to this, and something more than the awful odor of the soft-soap lather, added to that. Imagine it! But, like a stoic, I bore it without a murmur. Nay, I kept my fury so quiet that I did not even make a comment when Benjamin made the remark, for which I had been looking: "Dar now!" said he, "de blood ar done come, spite'o all I could do. Dis razor shave mighty easy, I boun; but den de skin on yo' nake 'pear to be monsus weak, monsus."

The fact is, the blood was trickling down my breast.

As I made no answer, Benjamin dipped his paint brush into the soap-gourd, lathered me anew, and kept on shaving.

"I done shave you down," said he, after awhile, "right clean and good. Now I gwine ter shave you up. I 'spec when it go agin de grain, it ar mos' likely to giv some trouble, but tain' no use o' shavin' unless you gwine ter do de thing as it ought to be done."

So he shaved me against the grain, and I gritted my teeth, determined to bear the torture without a groan, if I died under his hand. At last he got through "shav- 
ing me up" and began running his finger about in the greasy soap-suds on my throat to feel which way the beard grew, stopping now and then to staunch the flowing blood with a towel, and promising me that as soon as he got through he would make it all right "by plarsterin' de beard-holes with a little sut." In getting at the before-mentioned vortex of beard, he assumed all sorts of attitudes and bent my head and neck in all manner of directions, until I thought he would end by twisting my head entirely off. He got in front of me, behind me, on my right side, on my left side, and in between my legs. He was very rough and very determined to fulfill his promise to shave me two days under the skin. Still I gritted my teeth and let him keep on his murderous operation. The job was not an easy one. I felt something almost like pleasure when he began to perspire and to show anger, as if the beard were a personal enemy whom he could not conquer.

"Good G-d A'mighty! what a beard!" he at length exclaimed. "It 'pear to grow farst is you shave it." I answered not a word.

It is probable that I could have gone through with that terrific shaving without a syllable of complaint, if Benjamin had not wounded my pride as well as my person. Getting to a little spot just under the angle of my jaw, where the beard was peculiarly twisted in its growth, he became fairly puzzled. He did his best to get at it, but he could not. 'This way and that, behind me and before me, on either side, every way, he tried, but all in vain. 'Then it was that he broke out, 
in the most offensive tone imaginable, with the following unparalleled proposition.

"My little marster, there's 'bout three or fo' uv the outrajusist little hars here I uvver did see. I carn't gether um, all I kin do. Couldn't you-couldn't you -a-urrah-couldn't you jes stan' on yo' hade (head) for a minute or two, if you please, sir."

The words "stan' on yo' hade" were hardly out of his mouth before he was lying flat on his back. In a frenzy of passion, which had been restrained until it could be restrained no longer, I knocked him senseless with a chair. It was like lightning, so quickly and fiercely was it done; and to this day I have never been able to tell how I kept from killing him outright. And this was the way I got shaved in "Tcharlut." It is enough to make me "stan' on my hade" whenever I think of it. The rest of the adventure you shall hear.

\section{II}

\section{THE THROAT-CUT LOVER}

I LEFT Brileses' with a throat perfectly raw and bloody, the maddest man the world that day contained, and in the worst possible plight to go a courting. But go I must, and court I must. To return home would have been folly; I was under a solemn promise to be at the young lady's house by a certain day. So I paid Briles his bill-a very small one-accepted, not with the best grace, his condolence and his promise to thrash Benj'min soundly, indignantly rejected Mrs. 
Briles's proffer to "ease my misery by wropping my throat in a strip of fat bacon-rine that would go round twice't," and set forth. My throat pained me terribly; my anger was high, and I rode on as fast as my horse could carry me. The few persons I encountered eyed me with a strange look; but I was out of sight before they could make a remark. Crossing the river, I entered the County of Halifax-not without some awkward questions from the ferryman. Leaving the fertile lowlands, I ascended a low range of hills, trotted rapidly along the ridge, and about dinner hour found myself lost. Then, for the first time, I observed the very red aspect of my bosom. My collar was in even a worse condition; it was a bloody rag. My throat was still bleeding. Dismounting from my horse, I repaired to a marshy spot in the woods, and gave my neck a good bathing. The water was warm, but the astringent property imparted to it by the oak leaves which had fallen made it act like a charm. It staunched the blood completely, and, though it burnt me severely at first, produced the most soothing and grateful aftereffect. Feeling much relieved, I sat down on the root of a tree, and wiped my neck as well as I could with my handkerchief. I then concluded that the best thing, nay, the indispensable thing, for me to do, was to divest myself of my sanguineous under-garment, and put on a clean one. Accordingly, I went for my saddle-bags, brought them into the woods, about twentyfeet or more from the road, opened them, pulled out $a-a-a$ nicely ironed $a-$ urah, and proceeded to make a sylvan toilette. Meanwhile, I became exceedingly 
hungry. To stay my hunger, I lit a cigar. My garment was just on, but not a single button buttoned, when a negro boy came riding by on a mule, I called to him to stop. He did so; looked around, but saw nobody. I told him to wait a minute until I could get ready. Though he could not see me, I could see him very plainly; and as he was evidently a little frightened, I thought it advisable to go up to him, and ask him to tell me the way to the place I was going. Out I walked, accoutred as I was, white above and dark below-my pantaloons being dark grey-and cigar in mouth.

As soon as he saw me, he turned to run, but, on second thought held his ground. But the moment I got close to him, he bounced off the mule and ran through the woods, bawling as hard as he could. Of course I ran after him. It would never do to let slip the only chance $I$ had of ascertaining my whereabouts. The little devil ran like a deer; but after a hard chase I overtook him and collared him. The moment I laid my hands on him, he made the woods ring with piercing screams, and in a very short time I was surrounded by half a dozen rough, powerful white men, one of whom, armed with a sledge-hammer, threatened to "bust my derned head open ef I didn't let that ar boy go."

It turned out that the spot where I caught the boy was but a few hundred yards from the interesting village, or blacksmith's shop, of “Madison's Cross Roads," and that the amiable gentlemen who surrounded me comprised a large majority of its popula- 
tion. I explained to them at once the reason why I had run after the boy, and even went so far as to tell them about my getting shaved in Charlotte, thus accounting for the very suspicious appearance of my throat and the singularity of my costume. Some of them looked as if they believed me; others did not. I overheard one fellow whisper to his friend:

“'That man's bin hung. Don't you see his neck? He needn't tell me nothing 'bout his gittin' shaved at Briles's. Briles's Ben kin shave good as anybody.

"I think I heerd thar was a man hung last Friday in Pittsylvany, and that ar is the man to a dead moral certainty."

"I don't like his looks, neither," was the reply. "But if a man's bin hung wunst, you can't hang him nar a'nuther time for the same offenst. Its agin the law. But what was he a doing to Bruce's Jim? He couldn't a wanted to kill the nigger; reck'n he could?"

"Dunno," said the first speaker. "He's got the worst face I uvver see on top of any man. He ain't too good to commit murder jest to keep his hand in."

While this agreeable conversation was going on, I busied myself in buttoning up my apparel and making myself as decent as I could. By the time I got through the citizens of Madison's Cross Roads drew off a little way, as if to consult what was best to be done with me. I awaited patiently their decision. The spokesman came forward and said:

"Mister, you tell a mighty straight sort of story, but you've got a kind uv count'nance that none uv we all don't like. I don't want to hurt your feelins, but 


\section{MY VILE BEARD}

the sooner you git away from Madison's Cross Roads the better. You say you're going down to Squire Cookses. Well, you ken jes go 'long. But I'm a coming thar soon to-morrow morning, and ef your story ain't crobborated by facts, I'm gwine to take you up, according to law."

They all turned and walked off, taking Bruce's Jim with them. I laughed and went to my saddlebags, finished dressing, mounted my steed and started off quite gaily, both pain and hunger having disappeared under the excitement of my amusing interview with the fierce Madison's Cross Roaders. Unfortunately, the only information I had been able to get in regard to the locality of Squire Cooke's, was to the effect that it was "a right sharp ways down the road, jinin' John Thompson's land, after you get over the creek." As I rode on, it occurred to me that it would be a good thing to tie my handkerchief around my neck, which began to feel sore again, and to bleed a little. This I did, and felt the better for it. But now my hunger returned with great violence. I got down from my horse, and ate a few chestnuts that I found under the leaves; but these served only to make me still hungrier. I again mounted and rode forward. Emerging at length from the seemingly interminable woods, I beheld, to my great joy, an apple orchard, sure sign of a house in the neighborhood, though none was in view. A fine tree, loaded with big red apples, was not far from the fence, and in a very few minutes $I$ had a dozen in my hands and my pockets, and was sitting on the fence eating them with great relish. Up came a 
shabbily-dressed old fellow, riding a sorrel mare, with awkward colt behind her. Thinking him some thirdrate farmer, I hailed him in a free and easy manner, and asked him how far it was to old Squire Cooke's. He replied stiffly, that it was but a short distance. I told him that I was on the way to the squire's house, and as I had already lost myself twice, I would be obliged to him it he would show me the exact place.

The old fellow bestowed a suspicious glance upon me, wrinkled his shaggy eye-brows, in token of satisfaction or the reverse, and said:

"If you will follow me, I will show you the house."

You guess the sequel, $\mathrm{O}$ reader. The old fellow was Squire Cooke himself.

I spare you the recital of my inward pangs and confused apologies when the awkward discovery was made. One thing I congratulated myself upon, viz.: that I had not (as I was in an ace of doing several times) asked the old fellow if Squire Cooke was as well off as people said he was, and whether he was a skinflint, as I had heard.

My reception by Mrs. Cooke was kind, by her daughter cordial. The squire kept very grim. At dinner we had corn-pudding, late in the year as it was. Like a fool, I said nothing to account for the alarming appearance of my throat, which was fully exposed to view, owing to the fact that it was so sore outside that the bare idea of tying a cravat tightly around it, to hide it, was agonizing. The old lady, obliged to talk to me, always took care to let her eyes fall below the level of my hair, which was not pretty hair. My 
inamorata looked cold. The hideous redness of my throat had begun to tell on her. I felt uneasy. The servants gazed at me very much. Pater familias ate a great deal and said nothing. My face began to get as red as my throat. In this pleasant state of bashfulness, and while I was in the act of carrying the first forkful of corn-pudding to my mouth, the old gentleman addressed me a question. You know how corn-pudding retains its heat? I knew it too, but in my confusion forgot it. So when the old gentleman suddenly spoke to me, pop! the burning mass of cornpudding slipped off my fork, fell down my loose collar, and lodged exactly where my throat was rawest!! Don't ask what I did. Hah! but it was hot! If I didn't hear things fizz under the corn-pudding, I felt them. I did not sit still. I did not keep quiet. I did not display any heroism. I don't know precisely how I acted. 'Think I howled. Expect I danced round the room. Believe I swore. Remember I cried. The pain was mighty bad. The chagrin was worse. Know I cared nothing for the dignity of manhood. Know I tore open my collar, my bosom, my vest, and snatched out the pudding, as much as I could get of it. It burnt my fingers, and I slung it off, little caring where it went. Think it spattered the old gentleman's face. You are correct in saying that I ought not to have forgotten that I was in the presence of my sweetheart, and ought to have borne the pain with a smiling visage. I dare say. Yes, I ought to have been very smiling. But what is a sweetheart to a man with an ounce of corn-pudding frying away on his raw throat? 
Answer me that. Everything was done for me that could be done, and in process of time I became as easy as a man could well be under the circumstances. But I felt small inclination to make love to Miss Cooke. Nor did Miss Cooke seem to expect it. She played on the piano, talked about trifles, and was altogether too condoling. I discovered a number of defects in her character. She seemed fond of alluding to painful subjects. She lacked genuine feeling for the afflicted. There was a good deal of hypocrisy in her amiable nature. I was glad when bedtime came.

Slept badly. Throat hurt me. About day, fell into an uneasy doze, from which I was awakened by a noise in the yard. My friends of Madison's Cross Road had come to arrest me, as a man who had impertinently escaped from the gallows, and tried to kill or kidnap one of Bruce's negroes. Fortunately, the squire was a magistrate, and after hearing the evidence of his daughter, summoned into the parlor before sunrise as a witness, dismissed the case, and sent the Madison's Cross Roaders home, grumbling and dissatisfied. They wanted my blood; that was plain.

My trial did not improve my position as a suitor in the eyes of any of the family, and I knew it. My hopes were scattered to the winds. At breakfast, unable to eat any solid food, I swallowed my coffee in solemn silence, and as soon as the meal was ended, went forth to look after my horse. Outside of the stable I heard two negroes talking. One of them stuttered:

"D-d-d-dat ar man come cotin' Miss Sally-hehe ain't n-n-nothing but a tackey." 
"Hoccum he ain't? He got good hoss and bridle is anybody, don't keer whar they come from."

"He d-d-don't war no strops to his britchis.'

“But he got money-I seen it!" replied my defender.

"An-an-an he don't war no gallowses."

"Huccum he don't war no gallowses! How you know, I reckon!”

"Didn't I-I-I see him d-d-dis morning, when dey c-c-come to try him f-f-fore he dress?"

"Well, if you sho' he don't war no gallowses-ef you sho'-den de sooner he clear out from here de better. I don't wants to b'long to no man whar don't war gallowses, cause I nuvver see no gent'man but what he war'd gallowses-a par uv um. Evin a ove'seer, he war one. 'Spectable people nuvver fastens their britchis with a buckle and tongue, like a gearth, and Miss Sally ain't gwine hav him, ef you heer my racket."

This was enough for me. 'Two hours afterward I left Squire Cooke's. Never returned there-and never will-not if I had a million "par uv gallowses." 


\section{XII}

\section{A PIECE ABOU'T DOCTORS}

NE must be a bachelor of five and thirty, and often sick in his solitary room, to appreciate fully the comfort, and in fact the pleasure, of being sick as a married man. Many pleasant sicknesses have I had since my marriage, but the happiest of them all was one of the longest of them all-a six weeks attack of catarrh at Lichfield, in Orange County. During the paroxysms of coughing I suffered a good deal; at other times I was comparatively free of pain, and able to read and scribble at will. My good wife brought me my meals to a nice little upstairs room, warmed by a cosy wood fire. Without, all was cold and cheerless; within, all was sweet quietude and peace. The world with its sinfulness and its cares was far removed from me. I wanted never to go back to it again, and would fain have been an invalid all my days rather than encounter the temptations and troubles of life again. I look back upon that sickness as a glimpse, all too brief, of heaven. Dr. Edmond Taliaferro attended me. His visits were not numerous, but enough to impress indelibly upon my memory his quick bright eye, his perfect healthfulness ("sound as a nut" is truer of him than of any man I ever knew), 


\section{A PIECE ABOUT DOCTORS}

and his excellence as a man and a physician. How much good that admirable little man has done, and how poorly paid he has often been, there is no telling. From the bed in which I now lie I send him greeting, God-speed and a thousand kind wishes.

And what shall I say about that dear old doctor whose picture in my photograph album I looked at but yesterday, recalling the while the sad, happy memories of Middleburg? Hale and hearty, the picture of strength, able to buffet all the mountain storms that come, his joyous laugh comes to me over the years that have lapsed since we parted, and I can see him plainly in his front porch, with his grandchildren playing around him. He and his wife were with us that night when God called away the little boy who was the delight, the splendor and the hope of our lives, and he was with us that bright July morning when God sent us another son, "the sweetest boy in the world," as I called him in his babyhood, and often call him now, albeit he is six years old and over. This pulse in my wrist must be beating very slowly when I cease to remember with admiration and affection "Uncle William" and "Aunt Kate." Heaven send them a sweet sunset before the cloudless morning that awaits them hereafter.

Ah! Doctor, I'll tell you what I would like. I would like to present you with a golden backgammon box and a set of diamond men, and allow you to beat me one-just one-time in your life. It would make you so happy.

In "Abraham Page" or "What I know about Ben 281 


\section{A PIECE ABOUT DOCTORS}

Eccles," I forget which, there is the finest tribute to the country doctor that I have seen in ary language. But how is it that the theme never awakened the muse of Goldsmith or Shenstone or the pencil of a genre artist of the first order. The rusty long-tailed overcoat tucked well under the legs, the tall napless hat drawn down over the eyes, the ears protected by a comfort of a fiery red from cold, the beard white with snow or sleet, the compressed lips, the yellow leggings tied with green list, the thick yarn socks, knitted by some grateful hand, covering the boots, the gray saddle-blanket peeping out from under the sheepskin covered saddle, the black, medical saddle-bags, slick with long using, the faithful horse plodding through frozen mire or plashing through the puddles and brooks-here are the elements for a dark winter day -but better still, these same figures of horse and rider dimly describe through the thick darkness of the winter's night, when the fierce icy gusts are pouring through the mountain passes, bending the naked trees by the roadside, and almost beating down the gray-haired rider, who must trust to his sure-footed steed; for who can see the way on such a night in the midst of such a storm? And then the entrance of the doctor into the sick chamber lighted up by the log fire, the sick woman in the old-fashioned bed with valence and teaster turning her hollow eyes to him with an ineffable look of gladness and of hope.

What must be the thought of the good old doctor as he passes in through the tempest and the horror of thick darkness, often unattended and alone, oftener 


\section{A PIECE ABOUT DOCTORS}

still knowing that he can never be paid even a pittance for all he is braving and enduring! Memories of his student-life come to him, and of his early triumphs and failures in practice, of his first married days, of his own sick child left at home, and of the cozy chamber where his wife awaits his uncertain coming. Despite the rushing blast and the roaring mountain torrent he is fording, there come to him the cries of infants he has ushered into this world of pain, the last long suspiration and the wide ghastly yawn of the dying, the shrieks of bereaved women, and the suppressed tumultuous sob of stricken men-these come to him as he courageously breasts biting wind and freezing rain to reach his patient. In the cold gray dawn, his mission ended and the sufferer relieved, he sallies forth. The winds are still, the wide expanse of snow, unbroken yet by hoof or foot, stretches over the miles, no longer long, that lie between him and his home. As he beats onward the first smoke rises from the peaceful homesteads, and he hurries along to get his bright welcome and his wife's kiss, to snatch a breakfast and again to mount his horse and plod his daily round through snow and slush. And this is life to the country doctor and his fellows.

Brave hearts, noble gentlemen, benefactors seldom fully requited, in my summer trips away from the city I never pass one of you without an inward bowing of the head in reverence and the uttering of a silent benediction upon you. Ye are the salt of the earth, and your reward is assured in the bright hereafter.

Of late years our physician has been a sort of Quin283 


\section{A PIECE ABOUT DOCTORS}

bus Flestrin, or man-mountain, who has done so much for me and mine that it would be a relief to me to abuse him violently. It is not in the nature of a weakling like myself to look with complacency upon any man who is heaped up and running over with health. The Egyptians wrapped their dead in endless windings of cloth, but nature has bandaged Dr. Coleman with such great ropes and coils of bodily well-being that he may be regarded as a real mummy of health. Disease might feel for his vitals for a century to no purpose, and I should think that Death himself, after leveling his spear at him, would take a second look, and saying, "It's no use; that fellow is too thickly health-plated," pass on to the other side. Twice a day for many long months have I seen that strong Roman head enter my doorway, and once a day for weeks has he, on other occasions, visited me or my children. His ponderous tread and his portentous door-slam are familiar to us all. I should like to praise his skill, to tell about his art of winning the love of women and children, and the charm of his strong presence in the sick room, but may not trust myself. He has just delivered me from the pangs of diphtheria, and I might overdo the thing. Fain would I hope that I have done with him for a good long while at least; but I suspect that it will be another case of Michael and the dragon contending for the body of Moses, and that, after a sufficient number of brilliant victories, the dragon will at last get the better of Michael Coleman.*

* Alas! the patient and the physician were but a short time parted. Dr. Coleman was himself declining when he ministered 284 


\section{A PIECE ABOUT DOCTORS}

City physicians undergo less hardships and fatigue, but are subject oftentimes to a heavier weight of responsibility, than most of their country brethren. True, they have more and better appliances, and can generally call in consultation when needed more ability than the country doctor has at command; but endemics and epidemics sweep over the cities more often than the country, the ghastlier forms of schirrus and fungus are more prevalent there, and men of the greatest distinction, flocking to the cities, have more frequently to be treated. Moreover, the city physician is much more critically and jealously watched than his country brother. On the other hand, the latter has too of ten to rely wholly on himself in cases of the greatest emergency, as in accouchments and capital cases of surgery. But I will not pretend to strike the balance between them. God knows that both classes have a hard enough time. For nothing in this world would I undertake the labor or responsibility of either of them. Fact is, I couldn't; it is not in me, or anywhere about me.

To country and to city doctors I owe more than I can ever repay. I think that in this world it happens not seldom that they who would be princes in generosity, and give and give forever, are not only debarred from giving, but are doomed forever to receive; and I believe that in the great book of the recording angel there are pages upon pages filled with the credits of

to the sufferer in his final illness, and three months after the last sad scene of Dr. Bagby's life, he too was taken, and left a city in tears. 


\section{A PIECE ABOUT DOCTORS}

gratitude which found no voice for very shame of mere words of requital, and because the fitting deed could not go hand in hand with the warm will welling up from a profoundly thankful heart.

Ah! gentlemen, had I my way there would not be wanting some large silver watches and some moderately high-priced snuff-boxes for a good many of you. But in earnest, if I were a millionaire, I do not believe that all the stinginess incident to that affliction could keep me from setting rich men an example of honor done to those that richly deserve to be honored. Carrington should clear for me the most spacious room in the exchange. It should be most beautifully and becomingly decorated. There would I gather the brightest men and the loveliest women in the land, and my doctors from far and near should be there. At a fitting hour I would command the peace, and then some silver-tongued Keiley or Stringfellow, gifted in speech, should say the splendid words that ought to be said in praise of your noble profession. Then the sweetest girl in all Virginia-a doctor's daughter most likelyshould in the eyes of that brilliant assembly pin to your lapels the badge (newly instituted by myself) of the Knightly Order of the Golden Pill. No, I do but jest. She should decorate you with the cross of the Legion of True Honor, in that it would be given, not to the slayers, but to the savers of mankind. And then, oh then, there should be a supper, such a supper-a supper of the gods, an Olympian feast compounded for the special delectation of doctors, from which not one of you should rise till he felt too rich to accept a cent 
from A. T. Stewart or Wm. B. Astor. And then I would consider myself moderately even with a few of you.

However ill-paid and often unpaid physicians may be, they have the consolation of knowing that eminence and success in almost every other calling and profession is a selfish success limited in its good effects to the man and his immediate family; whereas in medicine great success is based, necessarily, upon great and wide-spread beneficence. To even moderately distinguished medical men, indeed to all but the very meanest and most worthless doctors, there must come thrills of pleasure so supreme that only the minister of the gospel who feels that he has been the instrument of saving a soul can hope to taste a pleasure at all comparable with it.

Faithful keepers of the great seal of family secrets, trusty wardens of the ineffably precious health of our loved ones, silent and pitying witnesses of human suffering and human weakness, who shall rightly tell your worth, and with what patent of nobility shall ye be fitly honored! Statistics show that, man for man, your profession has fewer culprits than any other whatsoever. The simple figures, unfeeling and unflattering, bear testimony to the lofty virtue of your calling. It is the hope of humanity, and there is reason for the hope, that the day will come when there shall be no more great lawyers, for there shall be no more litigation; when there shall be no great warriors, because wars shall have ceased; and when even the need for great statesmen shall have passed, since mankind will 


\section{A PIECE ABOUT DOCTORS}

have outlived the infirmities that demand legislative correction or restraint. But that day can never come on this earth when men will not die. A healthy race, obedient to the laws of right living, will require few doctors (doctors truly, that their chief functions will then be the teaching of sanitary principles, and the mode of life demanded for the highest physical development); but these few will be crowned with the laurel that once rested only upon the brow of the soldier, and with the bays that were reserved solely for the jurist and the statesman.

The mind makes many pictures, and this is one that often delights me. In the realm where there will be no use for doctors, but where many doctors shall be, it shall come to pass that beside the river of living waters, and under the trees whose leaves are for the healing of the nations, each upon his little knoll of emerald sward, the good doctors of this world shall be seated. Celestial airs, borne from the trembling wires of harps attuned to praise the Great Physician, and mingled with the divine odors of amaranth and asphodel, shall pass by on the soft, pulsing breeze. And around each doctor shall be the host, small or great as the case may be, of them to whom he ministered on earth. They shall press forward with lips no longer dumb, with hands no longer afraid to tell by their clasp what even the lips might not like to say, and with eyes blazing full and warm from the unmasked soul. And from lips and hands and eyes shall come measureless requital. And the little ones, the little ones whose first wail and whose last sigh the good 


\section{A PIECE ABOUT DOCTORS}

doctors heard, they shall come with purest kisses and cherubic palms, with such sweet thanks and caressing as only the always-angels know. And then-the picture falls softly and slowly away. 


\section{XIII}

\section{THE PAWNEE WAR}

\section{A REMINISCENCE}

I the southwestern corner of the Capital Square 1 there is a truncated brick tower, modelled apparently after the design of the Tower of Babel, as conceived by the artists who illustrate Sunday-school books, except that the sides of the superimposed layers do not slope, but run vertically up a distance of ten or fifteen feet, when they are suddenly contracted, and another layer of lesser diameter begins. Not above forty feet rises this humble and ugly structure. On the top of it there is a homely wooden belfry, and in that belfry a large bell hangs. In peace times this bell struck the hours of the day and night, gave the alarm of fire, and called the truant "Alligators"* from their

* For many years the members of the Virginia House of Delegates were nicknamed "Alligators." The origin of the term is said to be this: An uncouth, roughly dressed Dutchman one day attempted to make his way into the hall, but was met by the doorkeeper with the query, "What do you want?" I vants to go in dere." "Whom do you want to see?" "I don't vants to see nobody; I vants to go in." "You can't go in, sir; the House is in session, and it is against the rules. If you want to see any member I will call him out." "I vants to go in, "persisted the Dutchman. "I tell you again, you can't go in," retorted the doorkeeper angrily. "But I ish a Alligator." "A 
haunts in the barrooms and faro-banks when there was a close vote in the General Assembly-once the House of Burgesses-or important public business to be dispatched. On rare occasions, such as the John Brown excitement, the bell summoned the military population of the city to arms.

A room in the lower part of the little brick tower was used as a guard-house, as well for the policemen of Mayor Mayo (whose business was that precisely of other policemen) as for a squad of the State Guard, who acted as sentries about the capitol and watched over the penitentiary convicts employed in grading the walks, and ornamenting and improving the grass-plots, shrubbery, and trees that adorn the square. The State Guard would cry very small in comparison with the Coldstreams, or the Garde Imperiale. They numbered less than a hundred men; but they were well organized, drilled, and equipped, and commanded by a very competent officer in the person of Captain Dimmock, formerly of the United States Army. 'This single company of infantry contained every regular soldier Virginia had at her command when, true to her motto, Sic Semper Tyrannis, she raised her spear against the despot lately enthroned in Washington.

About one o'clock, P. 11., on the Sunday succeeding what " eried the puzzled doorkeeper. "I ish a Alligator mineself." The doorkeeper stared in amazement. "What did you say-a Alligator " "Yaw," roared the now excited Dutchman; "I ish one o' dem Alligators from the Kounty of Wit!" A light dawned on the doorkeeper's mind. "Now I understand you," he exclaimed; "you are a delegate from the county of Wythe. Walk in, sir." Ever since the term "Alligator" has been a household word in Virginia. 
the passage of the ordinance of secession, a soldier ascended the wooden steps under the bell in the little brick tower, seized the heavy clapper in his hand, made two hard strokes, paused an instant, and then made a third. Sullen and deep the notes floated out in the balmy spring air.

Far and wide the toscin rang over the city, then busy in the worship of the Prince of Peace. The clergymen of the many churches hard by the Capitol Square, who that morning for the first time had ceased to pray publicly for the President of the United States, were uttering the after-sermon petition, "Grant, O Lord, that the words that we have this day heard," when "the outward ears" of their kneeling congregations were smitten by the boding sounds from the brick tower. Ere the prayer was ended more than half the congregation had disappeared. Scarcely a man remained in the churches. The dismay of the clergymen at witnessing this sudden depletion of their flocks was surpassed only by the chill that struck to the hearts of the women when their "affrayed eyes" were opened, and fathers, husbands, sons, brothers, and lovers were missing.

Father of Mercy! was it possible that the hirelings of Lincoln had so soon gained the vincinity of the capital of the Old Dominion, and must priceless blood be shed immediately, and on the Sabbath day? What else could this alarm and the sudden disappearance of the men mean? How quickly the blooming cheeks paled, and the pulses in the slender wrists went cold and slow! 
There was no one in the city, familiar with "big wars," to command

"Silence that dreadful bell!"

The soldier with the clapper in his hand manfully anviled the resonant metal, and loud note succeeded hollow murmur until the whole April air seemed vibrating. Thousands of lips were pleading for information, and, for a time, none was found wise enough to answer. Some terrible thing had happened, or was about to happen on the instant. What was it? What could it be? "Rumor, painted full of tongues," was never so busy as during the half hour after the churches were closed and the congregations dispersed. But presently the true story was told, and passed from mouth to mouth in luurricd, sometimes trembling accents: The Governor of I irginia had received official intelligenee that the Yankee sloop-of-war "Pawnee" had passed City Point, at the confluence of the Appomattox and James Rivers, and was stcaming hard for Richmond, with the intention of shelling it and burning it to the ground!

Monstrous intelligence! City Point was sixty miles away; the river was narrow and tortuous; in many places the channel ran so close to the banks that the felling of a single tree would have arrested the progress of any vessel; besides, the Pawnee was a wooden ship (monitors yet lay dormant in the brain of Eriesson), and the steep bluffs on the farms of Drewry and Chaffin, which afterwarel served the city so woll, afforded admirable vantage ground for field-pieces and 
perfect shelter for marksmen. What gunboat would ever run such a gauntlet for the mad chance of shelling a city of forty thousand inhabitants? The foolhardiest midshipman in Uncle Sam's service, even when crazed with sweet champagne extracted from the pippins of the Jerseys and medicated in the cellars of the Five Points, never dreamed of so insane a project. All this is very plain, now that three eventful years overlie that memorable Sunday in Richmond. It was not so clear to the excited inhabitants, new to all the strategy and appliances of war. A few saw the absurdity of the matter; but the men made ready to meet the enemy, come how he might, though all felt that this aquatic onset was a most ungenerous and contemptible mode of attacking a people accustomed only to dryland engagements with partridges and squirrels. The companies of the First Regiment of Virginia Volunteers repaired promptly to their drill-rooms, and in an incredibly short space of time were ready for marching orders. Randolph's battery of light howitzers was equally prompt, and so was the only troop of horse the city could muster-the "Governor's Mounted Guard," as it was called. All told, there were perhaps between six and seven hundred organized men, most of whom were as familiar with military forms as volunteers in time of peace ever are. These were prepared for any duty they might be called on to perform in less than an hour from the time the bell began tolling.

There were some affecting scenes. Mothers. sisters, and sweethearts came down to the drill-rooms, to interchange a parting word with the young men, 
and to fill their haversacks with something good to eat. These tender, inexperienced girls beheld in imagination the manly forms of their loved ones torn and mangled by pitiless fragments of Yankee shells, soon to explode over the doomed eity, and in the midst of the serried ranks of infantry. No wonder the fine young fellows felt a tremor about the heart and a suffusion of the eyes which ill beeame veteran soldiers who had taken part in the John Brown war. No wonder they wished the "women would go home and quit bothering." But these partings, affeeting as they were, sank into insignificance when compared with the solemn and energetic earnestness of the male citizens who did not belong to the volunteer companies, but felt it, nevertheless, to be their bounden duty to defend their eity, their families, and their properties from the ravages of the ruthless and watery invader. There was a gathering in hot haste of these, which might well have vied with that in Belgium's capital, besung by the Lord George Gordon Noel Byron. What weapons did they not seize?-fowling-pieces mortally oxydized; immemorial duck-guns, of prodigious bore; aneient falehions that had flashed in the eyes of Cornwallis at Yorktown; pistols of every conceivable calibre, and of all possible shades of inutility; and, in one instance at least, a veritable blunderbuss, so encompassed with verdigris that it passed for a cueumber of precocious growth! All these, loaded or unloaded, with or without caps or flints, to fight a gunboat mounted with ten-inch Columbiads! Everything that could shoot or eut was called into 
requisition, and Sutherland the gunsmith, albeit it was Sunday, was called upon to open his store, and, complying, did a rousing business, disposing of nearly all his stock of arms and fixed ammunition in two short hours-the result of which was the enhancement, the very next day, of revolvers, bowie-knives, dirks, and even long-bladed clasp-knives, to the extent of full fifty per cent.

Heavier metal than any Sutherland had to sell was needed in the great trial at hand, and of this the citizen heroes were well aware. Accordingly, a party of them rushed to the Virginia armory, and out of the large store of ancient ordnance there accumulated, selected one of a pair of magnificent bronze guns, quaintly but beautifully embellished, which had been presented to the State by the Count de Rochambeau in the name of the French Government. This rare and costly piece, weighing probably two tons, was by some strange art, which the frenzy of the moment suggested, hoisted upon a dray, or some other strong vehicle. A mixed multitude of horses, mules, and men were hurriedly gathered, the motley motive power applied, and the whole party dashed up the hill to Main Street, and then down the street at a terrific pace, until they reached the Custom House, and there the brave old gun, indignant at the rough, unmilitary usage it had received, incontinently leaped out of the dray into the street, where it lay for many weeks, a stranded Triton among the schools of martial minnows that floated by it, much wondering at its great size and the purpose for which it had been placed in 
that position-the majority being of opinion that it was put there to defend, not the Custom House, for that contained no treasure, but the Virginia Banks, just opposite. How this was to be effected was not clear, seeing that the gun was on the ground and there was probably neither a ball nor a cartridge in the city to fit it; but the military critics of those days were mostly from the country, and not familiar, as thousands of them now are, with the manual of heavy artillery.

It must not be supposed that the infantry, light artillery and horse waited for the upsetting of the big gun. By no means. Long before they had marched off, under what commander-in-chief history has failed to record, in the direction of Rocketts-the euphonious title of the lower part of the city-near the wharves and the landings of the sea-going steamers that then plied between Richmond and the principal maritime cities of the North. Meantime every "coign of vantage" was occupied by anxious watchers. Wives, whose tearful weight had just relieved the throttled necks of husbands already heavily freighted with horsepistols, bowie-knives, brandy-flasks, and cold ham and biscuit, were now recovered from their "wounds," and straining their eyes from the upper windows and porches to catch the first glimpse of the dreaded Pawnee. The top of the capitol, the tops of houses, church steeples, the "observatories," as they are unscientifically called, of hotels, and every high point in and around the city, were alive with human beings. Church Hill in particular, which overlooks the river at Rocketts, was swarming with human beings of 
both sexes, all ages, and every complexion, for the negroes were now as anxious and excited as their masters and mistresses.

It was whispered that the Grand Army of Richmond intended to "make a stand" at Rocketts, and give battle to the Pawnee, for it was taken for granted that that vessel would make fast to the wharf before she opened her broadsides or gave tongue even to the pivot rifle in the bow. This was an additional incentive to the dense crowd on Church Hill to remain just where they were, at least until the enemy hove in sight. The army did make a stand at Rocketts, but it was merely a halt for refreshments-fresh quids of tobacco. The line of glittering bayonets was soon again in motion, the cannon rumbled, the war-horses kicked up a mighty dust, and the column quickly wound over the hill and was out of sight. Still the multitudes on the towers and house-tops watched and waited. Like a serpentine silver band the river lay stretched before them, miles and miles away, without a cloud to dim its tranquil argent sheen. Far or near, none could descry the Pawnee. The sun sank low, and at length set in the peaceful heavens. Still no Pawnee. Twilight deepened into night, the church bells called the people from the hills and house-tops to prayers-prayers of gratitude for deliverance from "the pestilence that steameth at noon-day." but doth not often venture up narrow, shallow, and unknown channels when thick darkness covereth the earth. The Pawnee never came. The troops bivouacked that night in the fields on the river-shore, some five or 
six miles below the city, and marched back the next day to resume the exereises which were to fit them for aetual service, of which they were destined to sce far more than they dreamed. The night was mild, and the mareh, the bivouac, and the shell practice in which the Howitzers indulged the following morning, were regarded by the "boys" as a jolly frolic. No aceident and but one untoward event happened. A son of Dr. Beverley Tucker, Professor in the Riehmond Medical College, contracted that night a pulmonary disease which speedily proved fatal. Young Tucker was, in Virginia at least, the first victim of the war.

Thus began, progressed, and ended the famous "Pawnee War." We may laugh at it now, for there were many laughable things alout it. Not the least of these was the consternation produced in the eountry about Richmond by the exaggerated reports carried out of the corporate limits by self-elected couricrs. Among other wild stories, was one to the effect that the Pawnee Indians had come down the Central Railroad, taken possession of the eity, and were sealping and tomahawking the citizens at a frightful rate. 'This story was actually believed, and many agitated ladies fled to the house of a daughter of General Richardson, the Adjutant-General of Virginia, as if there was a charm about that powerful title which ensured safety to all its owner's relatives and friends. Yes, we may laugh at the Pawnee War, and own frankly that there was something of a panic that day in Richmond. But then, as in times more alarming, when the tocsin 
again sounded, and with better cause, Richmond showed fight, and doubtless would have made it had there been occasion. If that was her first panic, it was her last. A year afterward one hundred thousand men, and thrice one hundred pieces of cannon threatened her, with scarce an earthwork between them and their prey; but she was calm and smiling, for Lee confronted the host of her foes, and Jackson was coming. 


\section{XIV \\ HOW RUBENSTEIN PLAYED}

" JUD, they say you heard Rubenstein play when you were in New York."

"I did, in the cool."

"Well, tell us about it."

"What! me? I might's well tell you about the creation of the world."

"Come, now; no mock modesty. Go ahead."

"Well, sir, he had the blamedest, biggest, cattycornedest pianner you ever laid eyes on; somethin' like a distractid billiard table on three legs. The lid was heisted, and mighty well it was. If it hadn't been he'd a-tore the intire insides clean out, and scattered 'em to the four winds of heaven."

"Played well, did he?"

"You bet he did; but don't interrup' me. When he first set down he 'peard to keer mighty little 'bout playin', and wished he hadn' come. He tweedleleedled a little on the trible, and twoodle-oodle-oodled some on the base-just foolin' and boxin' the thing's jaws for bein' in his way. And I says to a man settin' next to me, s'I, 'what sort of fool playin' is that?' And he says, 'Heish!' But presently his hands commenced chasin' one 'nother up and down the keys, 301 
like a passel of rats scamperin' through a garret very swift. Parts of it was sweet, though, and reminded me of a sugar squirrel turnin' the wheel of a candy cage.

“' Now,' I says to my neighbor, 'he's showin' off. He thinks he's a doing of it; but he ain't got no idee, no plan of nuthin'. If he'd play me up a tune of some kind or other, I'd-

“But my neighbor says 'Heish!' very impatient.

"I was just about to git up and go home, bein' tired of that foolishness, when I heard a little bird waking up away off in the woods, and calling sleepylike to his mate, and I looked up and I see that Ruben was beginnin' to take some interest in his business, and I set down agin. It was the peep 'o day. The light come faint from the east, the breeze blowed gentle and fresh, some more birds waked up in the orchard, then some more in the trees near the house, and all begun singin' together. People begun to stir, and the gal opened the shutters. Just then the first beam of the sun fell upon the blossoms; a leetle more and it tetcht the roses on the bushes, and the next thing it was broad day; the sun fairly blazed; the birds sang like they'd split their little throats; all the leaves was movin', and flashin' diamonds of dew, and the whole wide world was bright and happy as a king. Seemed to me like there was a good breakfast in every house in the land, and not a sick child or woman anywhere. It was a fine mornin'.

"And I says to my neighbor, 'That's music, that is.' “But he glar'd at me like he'd like to cut my throat. 
"Presently the wind turned; it begun to thicken up, and a kind of gray mist come over things; I got lowspirited d'rectly. Then a silver rain began to fall. I could see the drops touch the ground; some flashed up like long pearl ear-rings, and the rest rolled away lice round rubies. It was pretty, but melancholy. Then the pearls gathered themselves into long strands and necklaces, and then they melted into thin silver streams running between golden gravels, and then the streams joined each other at the bottom of the hill, and made a brook that flowed silent except that you could kinder see the music, specially when the bushes on the banks moved as the music went along down the valley. I could smell the flowers in the meadow. But the sun didn't shine, nor the birds sing; it was a foggy day, but not cold. The most curious thing was the little white angel boy, like you see in pictures, that run ahead of the music brook, and led it on, and on, away out of the world, where no man ever was $-I$ never was, certain. I could see that boy just as plain as I see you. Then the moonlight came, without any sunset, and shone on the grave-yards, where some few ghosts lifted their hands and went over the wall, and between the black sharp-top trees splendid marble houses rose up, with fine ladies in the lit up windows, and men that loved 'em, but could never get a-nigh 'em, and played on guitars under the trees, and made me that miserable I could a-cried, because I wanted to love somebody, I don't know who better than the men with guitars did. Then the sun went down, it got dark, the wind moaned and wept like a lost child 303 
for its dead mother, and I could a got up then and there and preached a better sermon than any I ever listened to. There wasn't a thing in the world left to live for, not a blame thing, and yet I didn't want the music to stop one bit. It was happier to be miserable than to be happy without being miserable. I couldn't understand it. I hung my head and pulled out my hankerchicf, and blowed my nose loud to keep from cryin'. My eyes is weak anyway; I didn't want anybody to be a-gazin' at me a-snivlin', and its nobody's business what I do with my nose. It's mine. But some several glared at me, mad as Tucker.

"Then, all of a sudden, old Ruben changed his tune. He ripped and he rar'd, he tipped and tar'd, he pranced and he charged like the grand entry at a circus. 'Peared to me that all the gas in the house was turned on at once, things got so bright, and I hilt up my head, ready to look any man in the face, and not afeard of nothin'. It was a circus, and a brass band, and a big ball, all goin' on at the same time. He lit into them keys like a thousand of brick, he give 'em no rest, day nor night; he set every livin' joint in me a-goin', and not bein' able to stand it no longer, I jumpt spang onto my seat, and jest hollored: " 'Go it, my Rube!'

"Every blamed man, woman and child in the house riz on me, and shouted, 'Put him out! put him out!' “'Put your great-grandmother's grizzly-gray-greenish cat into the middle of next month!' I says. 'Tech me, if you dare! I paid my money, and you jest come a-nigh me.' 
"With that, some several p'licemen run up, and I had to simmer down. But I would a fit any fool that laid hands on me, for I was bound to hear Ruby out or die.

"He had changed his tune again. He hopt-light ladies and tip-toed fine from eend to eend of the keyboard. He played soft, and low, and solemn. I heard the church bells over the hills. The candles in heaven was lit, one by one. I saw the stars rise. The great organ of eternity began to play from the world's end to the world's end, and all the angels went to prayers. Then the music changed to water, full of feeling that couldn't be thought, and began to dropdrip, drop, drip, drop-clear and sweet, like tears of joy fallin' into a lake of glory. It was sweeter than that. It was as sweet as a sweetheart sweetenin' sweetness with white sugar, mixt with powdered silver and seed diamonds. It was too sweet. I tell you the audience cheered. Ruben he kinder bowed, like he wanted to say, 'Much obleeged, but I'd rather you wouldn't interrup' me.'

"He stopt a minute or two, to fetch breath. Then he got mad. He run his fingers through his hair, he shoved up his sleeves, he opened his coat tails a leetle further, he drug up his stool, he leaned over, and, sir, he just went for that old pianner. He slapt her face, he boxed her jaws, he pulled her nose, he pinched her ears and he scratched her cheeks, till she farly yellecl. He knockt her down and he stompt on her shameful. She bellowed like a bull, she bleated like a calf, she howled like a hound, she squecled like a pig, she 305 
shrieked like a rat, and then he wouldn't let her up. He run a quarter-stretch down the low grounds of the base, till he got clean into the bowels of the earth, and you heard thunder galloping after thunder, through the hollows and caves of perdition; and then he foxchased his right hand with his left till he got away out of the treble into the clouds, whar the notes was finer than the pints of cambric needles, and you couldn't hear nothin' but the shadders of 'em. And then he wouldn't let the old pianner go. He for'ardtwo'd, he crost over first gentleman, he crost over first lady, he balanced to pards, he chassade right and left, back to your places, he all hands'd aroun', ladies to the right, promenade all, in and out, here and there, back and forth, up and down, perpetual motion, doubled and twisted, and tied, and turned, and tacked, and tangled into forty-'leven thousand double bowknots. By jings! it was a mixtery. And then he wouldn't let the old pianner go. He fetcht up his right wing, he fetcht up his left wing, he fetcht up his centre, he fetched up his reserves. He fired by file, he fired by platoons, by company, by regiments and by brigades. He opened his cannon, siege guns down thar, Napoleons here, twelve-pounders yonder, big guns, little guns, middle-size guns, round shot, shell, shrapnel, grape, canister, mortars, mines and magazines, every livin' battery and bomb a'goin' at the same time. The house trembled, the lights danced, the walls shuk, the floor come up, the ceilin' come down, the sky split, the ground rockt-heavens and earth, creation, sweet potatoes, Moses, nine-pences, 306 
glory, ten-penny nails, my Mary Ann, hallelujah, Samson in a 'simmon tree, Jeroosal'm, Tump 'Tompson in a tumbler-eart, roodle-oodle-oodle-oodleruddle-uddle-uddle-uddle-raddle-addle-addle-addleaddle-riddle-iddle-iddle-iddle - reetle-eetle-eetleeetle-eetle-eetle-p-r-r-r-r-r-lang! per lang! per plang! p-r-r-r-r-r-r-r-lang! Bang!

"With that bang! he lifted hisself bodily into the ar', and he come down with his knees, his ten fingers, his ten toes, his elbows and his nose, striking every single solitary key on that pianner at the same time. The thing busted and went off into seventeen hundred and fifty-seven thousand five hundred and forty-two hemidemi-semi-quivers, and I know'd no mo'.

"When I come too, I were under ground about twenty foot, in a place they call Oyster Bay, treatin' a Yankee that I never laid eyes on before, and never expect to ag'in. Day was a breakin' by the time I got to the St. Nicholas Hotel, and I pledge you my word I didn't know my name. The man asked me the number of my room, and I told him, 'Hot music on the half-shcll for two!' I pintedly did.” 


\section{FILL JOANSES}

\section{A MONEFUl DitTE}

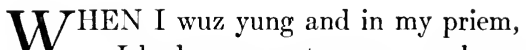
I had sum meat uppun my boanses;

I loss it all in sicks weeks' time, At a place they call Fill Joanses.

Too and 20 yeer agoe it were-

I cack'late it by my groansesThat I set 4th from Linchbug toun On a vizzit to Fill Joanses.

Miss Bobry, she wuz with me, too, And Wilyum, bruther of Fill Joanses, Miss Jessie, with her eye so blue,Wuz all a-stayin' at Fill Joanses.

'Twuz in the good old days of oleWe was Monnuks on our throansesThe crap was wuth its weight in gole, At the plais they call Fill Joanses.

Fillup then were but a boy,

And Sedden toddlin oar the stoanses, He holp us to cumpleet our joy

While a-stayin' at Fill Joanses. $30 \mathrm{~s}$ 
Big Mister Willis at the mill, $H e$ had sum meat uppun his boanses; Frank Gnawl, he clum the red-clay hill, And Farmer John cum down to Joanses.

Miss Mary Stannud, she was thar,How mellojus was her toanses! Anuther gearl that had black har, And menny mo', wuz at Fill Joanses.

Sech dinin' out and dinin' in, Sech drivin' o'er the roeky stoanses!

My soul! I think it were a $\sin$, The way they liv'd aroun' Fill Joanses.

Sech lamb and jelly-everything,-But I were usen to corn poanses; Fat mutton was the truck-by jing! That laid me out at Fillup Joanses.

For from that day untoo this hourThe sartin faek to all well known isMy stummuk, she have loss her power, And leff it all at Fillup Joanses.

Dyspepsy are a fearful ill;

'Tis made of grunts and made of groanses;

No tiem will settle that ar bill That I cuntrackted at Fill Joanses.

My days is past in constunt pain, My nites in everlastin' moanses; 


\section{FILL JOANSES}

And oft I cuss, and cuss in vain, That fatal summer at Fill Joanses.

But sert'ny I duz luv to eet-

Man warn't made to live on stoanses;

And now I know 'twuz hard to beat

That blessid summer at Fill Joanses.

Ah! tiems is sadly changed since then;

The Yanks has got us for thar oanses;

'Thar's not a man, not one in ten, Livs like they lived at Fillup Joanses.

Bad as I feel, ef I could bring Them days agin, I'd heish my groanses;

I'd fill my stummuk with mint sling, And dine wunst mo' at Fillup Joanses.

The good ole man is livin' still, As young as ever in his boanses;

Lass tiem I clum the red-clay hill, They had good eatin' at Fill Joanses.

So mote it bee, so mote it bee,

Twell deth shall heish up all our groanses; For not twell then will I agree

To eat no mo' at Fillup Joanses. 


\section{AFTER APPOMATTOX}

"On his way to Richmond, General Lee stopped for the night near the residence of his brother, Mr. Carter Lee, of Powhatan county; and, although importuned by his brother to pass the night under his roof, the General persisted in pitching his tent by the side of the road, and going into camp as usual."-Taylor's "Four Years with General Lee," page 154.

UPON a hill-top, bold and free, Ere that sad day is done, The soldier form and face of Lee Stand out against the sun.

The strong, grey head is carried high, The firm hand grasps the rein; Earth nowhere holds such majesty, And nowhere hides such pain.

A little onward now he rides, For he alone would be; But something more than space divides His staff from Robert Lee.

Scarce can he tell the way he gocs, Scarce feels the April air; 
Heap'd in his breast, his country's woes Have filled him with despair.

The purple mountains fade behind, Before him lies the sea; In all this world a fate unkind Leaves home nor hope for Lee.

The rosy flush dies on the plain, And dismal shadows start; What tumult in his riven brain, What torture in his heart!

The bright'ning stars are naught to him, Nor aught the sweet moonlight; His star has grown a-sudden dimHe never more shall fight.

His work seems done, his day seems spent;

What matters night or day!

He will betake him to his tent, And, kneeling there, will pray.

The cries that upward went that night

Unto the great White Throne-

The tears for guidance and for light-

To God alone are known.

Sacred throughout all coming time, Those sleepless hours shall be; For who can tell, in words sublime, The agony of Lee? 



LIBRARY OF CONGRESS

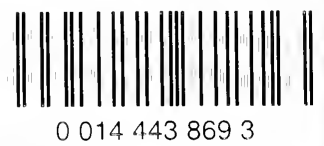

